Illinois State University

ISU ReD: Research and eData

Theses and Dissertations

$11-5-2018$

\title{
Locating the Critical Component in Technological Pedagogical and Content Knowledge (TPACK): An Examination of How Graduate Students Recruit TPACK and Critical Digital Literacy into Classroom Practices.
}

Vicki Ann Hosek

Illinois State University, vhosek4@gmail.com

Follow this and additional works at: https://ir.library.illinoisstate.edu/etd

Part of the Instructional Media Design Commons

\section{Recommended Citation}

Hosek, Vicki Ann, "Locating the Critical Component in Technological Pedagogical and Content Knowledge (TPACK): An Examination of How Graduate Students Recruit TPACK and Critical Digital Literacy into Classroom Practices." (2018). Theses and Dissertations. 1011.

https://ir.library.illinoisstate.edu/etd/1011

This Dissertation is brought to you for free and open access by ISU ReD: Research and eData. It has been accepted for inclusion in Theses and Dissertations by an authorized administrator of ISU ReD: Research and eData. For more information, please contact ISUReD@ilstu.edu. 
LOCATING THE CRITICAL COMPONENT IN TECHNOLOGICAL PEDAGOGICAL AND

CONTENT KNOWLEDGE (TPACK): AN EXAMINATION OF HOW GRADUATE

STUDENTS RECRUIT TPACK AND CRITICAL DIGITAL LITERACY INTO

CLASSROOM PRACTICES

\section{VICKI ANN HOSEK}

\section{Pages}

The objectives of this study were to gain an understanding of how practicing teachers believe they are prepared to meaningfully and critically integrate technology into their classroom practices; and to understand how practicing teachers recruited those beliefs into their teaching practices. This included gaining an understanding of what they believed led to their engagement in the critical dimensions of technology use in their teaching practices. This mixed-methods study contained two phases. In Phase 1, 58 graduate students in a College of Education completed a newly developed Critical Technological Pedagogical Content Knowledge (CTPACK) survey containing likert-scale and open-ended questions. A subset of four graduate students, who were also practicing teachers, participated in Phase 2 of this study where lesson plans, observations, and interviews were analyzed. The findings indicated that limited experiences with and exposure to C-TPACK during teacher education coursework and professional development (PD), uncertainty about students' critical digital literacies (CDL), the teachers' varying understandings of CDL, resource limitations and restrictive school policies posed barriers for the teachers' recruitment of CTPACK to their practices. These findings showed the importance of tying critical theory to technology in education coursework and PD 
programs. This study proposes the use of a theoretical framework that prioritizes critical theory, namely the C-TPACK framework, when analyzing teachers' technology integration practices.

KEYWORDS: TPACK, C-TPACK, critical digital literacy, digital literacy, teacher education, professional development 
LOCATING THE CRITICAL COMPONENT IN TECHNOLOGICAL PEDAGOGICAL AND

CONTENT KNOWLEDGE (TPACK): AN EXAMINATION OF HOW GRADUATE

STUDENTS RECRUIT TPACK AND CRITICAL DIGITAL LITERACY INTO

CLASSROOM PRACTICES

VICKI ANN HOSEK

A Dissertation Submitted in Partial

Fulfillment of the Requirements

for the Degree of

DOCTOR OF EDUCATION

School of Teaching and Learning

ILLINOIS STATE UNIVERSITY

2018 
Copyright 2018 Vicki Ann Hosek 
LOCATING THE CRITICAL COMPONENT IN TECHNOLOGICAL PEDAGOGICAL AND

CONTENT KNOWLEDGE (TPACK): AN EXAMINATION OF HOW GRADUATE

STUDENTS RECRUIT TPACK AND CRITICAL DIGITAL LITERACY INTO

CLASSROOM PRACTICES

VICKI ANN HOSEK

COMMITTEE MEMBERS:

Lara J. Handsfield, Chair

Sonia Kline

Anna Smith 


\section{ACKNOWLEDGMENTS}

First and foremost, I want to thank God for providing me with the courage and strength to pursue my doctorate. He provided a path filled with opportunities to work toward something amazing in the midst of tremendous personal hardship and struggle. God always provides.

I have been blessed with amazingly supportive parents. Ray and Gloria Hosek, from the moment I mentioned my idea to pursue my doctorate, you offered so much encouragement and faith in my ability to earn it. You instilled in our family the incredible value of education which led me pursue this dream. I am forever grateful to you for your love and belief in me. I have also been blessed with three daughters who are as beautiful inside as they are out. Chloe, Delaney, and Campbell, you have supported me every step of the way on this extremely difficult journey, and I could not be more thankful to you for your love and support.

I am especially thankful for the help and guidance of Lara Handsfield, my Advisor and Chair. I will always be grateful that you recognized my need for guidance and stepped up without missing a beat. Your expert advice led me to ask Sonia Kline and Anna Smith for their help. As a committee, you all encouraged me to run with the C-TPACK concept, pushing me to think deeply, and then pushing me even more. Thank you all for believing that I could do this as that helped me believe it too.

I lovingly dedicate this dissertation to my three strong, smart, Christian daughters. Know that no matter what hardship enters your life, you can find the strength and courage to get to the other side of it. There is power in the journey. Always remember, God is good, even during the difficult process.

V. A. H. 


\section{CONTENTS}

Page

ACKNOWLEDGMENTS

TABLES Vii

FIGURES Viii

CHAPTER I: INTRODUCTION 1

Critically Navigating Digital Environments 2

Teacher Education, Teacher Development, and Digital Literacy $\quad 4$

$\begin{array}{ll}\text { The TPACK Framework } & 5\end{array}$

$\begin{array}{ll}\text { Contributing Theoretical Frameworks } & 7\end{array}$

Street's New Literacy Studies and Lankshear and Knobel's New Literacies $\quad 8$

$\begin{array}{ll}\text { CDL Framework } & 12\end{array}$

Technological, Pedagogical, Content Knowledge (TPACK) 16

The Role of Critical Literacy Frameworks in TPACK 20

Locating the "C" in the C-TPACK Framework 23

$\begin{array}{ll}\text { Summary } & 24\end{array}$

$\begin{array}{ll}\text { Terminology } & 25\end{array}$

CHAPTER II: LITERATURE REVIEW 26

Technological Pedagogical Content Knowledge (TPACK) Studies $\quad 27$

Theoretical Foundations of TPACK Research 31

$\begin{array}{ll}\text { Measuring TPACK } & 32\end{array}$

The Missing Contextual Element in TPACK Studies 36

$\begin{array}{ll}\text { Implications for Future Research } & 38\end{array}$ 
Critical Digital Literacy Studies $\quad 41$

Technology Integration in Classroom Practices 45

$\begin{array}{ll}\text { Conclusion } & 49\end{array}$

CHAPTER III: METHODOLOGY 51

Methodology 52

Ontological and Epistemological Beliefs $\quad 54$

Social Constructivism $\quad 59$

$\begin{array}{ll}\text { Constructivist Grounded Theory } & 61\end{array}$

$\begin{array}{ll}\text { Research Design } & 62\end{array}$

$\begin{array}{ll}\text { Participants and Setting } & 63\end{array}$

$\begin{array}{ll}\text { Data Collection Procedures } & 65\end{array}$

$\begin{array}{ll}\text { Phase } 1 & 66\end{array}$

$\begin{array}{ll}\text { Phase } 2 & 70\end{array}$

$\begin{array}{ll}\text { Data Analysis Procedures } & 75\end{array}$

$\begin{array}{ll}\text { Quantitative Analysis } & 76\end{array}$

$\begin{array}{ll}\text { Qualitative Analysis and Coding } & 76\end{array}$

“Themeing” the Data $\quad 83$

$\begin{array}{ll}\text { Trustworthiness and Reflexivity } & 90\end{array}$

$\begin{array}{ll}\text { Researcher Positionality and Bias } & 90\end{array}$

Member Checking $\quad 96$

$\begin{array}{ll}\text { Concluding Thoughts } & 98\end{array}$

CHAPTER IV: QUANTITATIVE ANALYSIS AND FINDINGS 99

C-TPACK of Phase 1 Participants 99 
$\begin{array}{ll}\text { Phase } 1 \text { Participants } & 99\end{array}$

$\begin{array}{ll}\text { Findings } & 128\end{array}$

$\begin{array}{ll}\text { Discussion } & 128\end{array}$

Phase 2 Subset of Participants 129

$\begin{array}{ll}\text { CTPACK of Phase 2 Participants } & 131\end{array}$

Findings and Discussion for Phase 2 Participants 131

$\begin{array}{ll}\text { Concluding Thoughts } & 133\end{array}$

CHAPTER V: QUALITATIVE ANALYSIS AND FINDINGS 135

$\begin{array}{ll}\text { Overview } & 135\end{array}$

Findings and Discussion: Phase 2 Participants 135

$\begin{array}{ll}\text { Diane } & 137\end{array}$

$\begin{array}{ll}\text { Survey Results } & 138\end{array}$

$\begin{array}{ll}\text { Lesson Plan } & 139\end{array}$

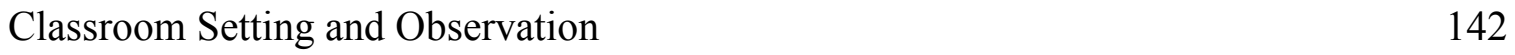

$\begin{array}{ll}\text { Interview } & 151\end{array}$

$\begin{array}{ll}\text { Kate } & 158\end{array}$

$\begin{array}{ll}\text { Survey Results } & 160\end{array}$

$\begin{array}{ll}\text { Lesson Plan } & 161\end{array}$

Classroom Setting and Observations $\quad 164$

$\begin{array}{ll}\text { Interview } & 166\end{array}$

$\begin{array}{ll}\text { Andrew } & 174\end{array}$

$\begin{array}{ll}\text { Survey Results } & 176\end{array}$

$\begin{array}{ll}\text { Lesson Plans } & 180\end{array}$ 
Interview

Sara

Survey Results

Lesson Plan

Classroom Setting and Observation

Interview

Recruiting C-TPACK in Planning and Instruction

Pedagogical Beliefs Reflected in Decisions

The Missing "C" in C-TPACK

Reflective and Reflexive Technology Integration Teaching Practices

Factors Impacting Teachers' Engagement

Limited of Exposure to C-TPACK

Uncertainty About Students' Critical Digital Literacies

Teachers' Understanding of Critical Theory

Resource Limitations and School Policies 
Research Question 2

$\begin{array}{ll}\text { Research Question } 3 & 235\end{array}$

$\begin{array}{ll}\text { Limitations } & 239\end{array}$

$\begin{array}{ll}\text { Implications } & 241\end{array}$

$\begin{array}{ll}\text { Implications for Research } & 241\end{array}$

The C-TPACK Framework $\quad 242$

Longitudinal Studies of Teacher's Recruitment of the "C" in C-TPACK 246

$\begin{array}{ll}\text { Future Practices in Teacher Development } & 248\end{array}$

$\begin{array}{ll}\text { Final Thoughts } & 253\end{array}$

$\begin{array}{lr}\text { REFERENCES } & 254\end{array}$

APPENDIX A: GRADUATE STUDENTS SELF-INDICATED CONTENT AREAS 279

APPENDIX B: PHASE 1- INFORMATION AND CONSENT FORM FOR RESEARCH

$\begin{array}{ll}\text { PROJECT } & 283\end{array}$

APPENDIX C: PHASE 2 INFORMATION AND CONSENT EMAIL 287

APPENDIX D: SURVEY OF TEACHER KNOWLEDGE OF TEACHING AND

$\begin{array}{lr}\text { TECHNOLOGY } & 290\end{array}$

APPENDIX E: INTERVIEW PROTOCOL AND QUESTIONS GUIDE 322

$\begin{array}{ll}\text { APPENDIX F: DIANE'S LESSON PLAN } & 325\end{array}$

$\begin{array}{ll}\text { APPENDIX G: KATE’S LESSON PLAN } & 326\end{array}$

$\begin{array}{ll}\text { APPENDIX H: SARA'S LESSON PLAN } & 328\end{array}$ 


\section{TABLES}

Table

Page

3.1 Demographics of Phase 2 Participants

3.2 Lesson Plan Construct Table with Descriptive Coding

3.3 In Vivo Coding from Andrew's Interview

3.4 Example of Process Coding for Kate

3.5 Four Resources for Multimodal Texts Model

3.6 Coding with Memos from Observations of Diane

5.1 Demographics of Phase 2 Participants

136 


\section{FIGURES}

Figure $\quad$ Page

3.1 Example of Themes and Concept Map $\quad 83$

3.2 SAMR Model 86

$\begin{array}{ll}4.1 \text { Technology Knowledge } & 100\end{array}$

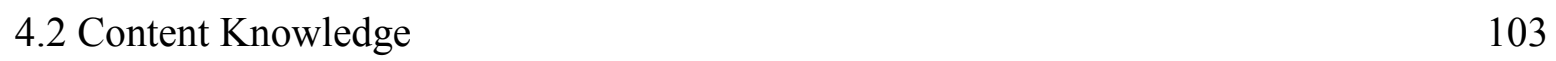

$\begin{array}{ll}4.3 \text { Pedagogical Knowledge } & 106\end{array}$

$\begin{array}{ll}\text { 4.4 Pedagogical Content Knowledge } & 109\end{array}$

4.5 Technological Content Knowledge 112

4.6 Technological Pedagogical Knowledge 115

4.7 Technological Pedagogical Content Knowledge 119

4.8 Critical Technological Pedagogical Content Knowledge (C-TPACK) 123

5.1 Worksheet from Diane's Lesson 144

$\begin{array}{ll}5.2 \text { Andrew's URQs } & 178\end{array}$

5.3 Andrew's Quiz Question 185 


\section{CHAPTER I: INTRODUCTION}

What has become evident, especially because of the introduction of digital media in our culture, is the need to move beyond traditional conceptions of formal versus informal ways of learning and literacy. Young people as learners move between different contexts of learning, both offline and online, in a constant flow of activities. (Erstad, 2012, p. 26)

My interest in studying critical digital literacy and classroom technology was sparked by a conversation I had with my daughters one night during dinner a couple of years ago. My middle daughter, age fourteen at the time, asked me if I could "update" her about what was happening in the news. Caught off-guard, I asked her what she already knew was going on so I could have a starting point. She told me that the only things she knew about were events she read on Twitter, and she was pretty sure that other things were happening in the world. To me, this was a vivid example of how our children engage in literacy practices across all of the environments they move in and out of throughout each day. They are constantly navigating, creating, and negotiating with and through information they obtain through digital media outlets, such as Twitter.

Honestly, at the time, I was surprised to hear that my daughter's primary daily news source was Twitter. However, as I have watched my own daughters and students continually and increasingly rely on different online platforms as a primary resource for information and communication, I am no longer unaware of the impact that digital environments have on their literacy development. This led me to consider whether students are evaluating the reliability, accuracy, and equity of representation of the information and the power structures and discourses 
at work in the online environments they are accessing, processing, and internalizing as they use technology in and out of the classroom.

In a study conducted by the Stanford History Education Group (Domonoske, 2016), findings indicated that "more than $80 \%$ of middle schoolers believed that 'sponsored content' was a real news story" (Paragraph 14). As digital environments contribute so strongly to students' knowledge bases and impact their views about the world and themselves, learning to operate, communicate, and navigate those muddy, often impartial waters is a necessary part of their literacy practices. This prevalence of digital media in the lives of youth today is undeniable. In fact, according to a Pew Research study (Leinhart, 2015), 92\% of teenagers go online daily. Currently, $88 \%$ of schools in the United States have broadband access (Leinhart, 2015).

As technology has become more accessible and connected, it has woven its way into teachers' and students' lives, both inside and outside of the classroom, and impacts how we interpret knowledge, create content, and make meaning of the experiences we have in digital environments. The texts that students experience and engage with in this social, digital culture inform their opinions, thoughts, actions, creations, and representations of themselves and, as such, are literacy practices (Blikstad-Balas, 2015; Jones \& Hafner, 2012). I believe that one must consider sociocultural context when understanding literacy, and digital environments are now a part of this sociocultural landscape.

\section{Critically Navigating Digital Environments}

Operating in digital environments requires an understanding of how moving within and between contexts and social structures impacts learning and is essential to understanding and valuing digital literacies. Stornaiuolo and LeBlanc (2016) explained that "literacy practices and

texts are always dynamically constructed in relation to hierarchical orders of varying spatial and 
temporal dimensions" (p. 264). This led me to consider how educators can ensure that our students are critically navigating the information that is at their fingertips in this digital age. Such navigation skills are essential if all students are to have equal opportunity to express and represent themselves through texts offered in digital spaces.

Ideally, digital environments can offer opportunities for dialogic spaces where there is freedom and opportunity for reflection and action of all participants to create and/or recreate their knowledge and understanding of the world. Such environments provide opportunities where "the reading and the rereading of the word and the world" (Freire, 1970) take place. Freire (1970) explained that "Only dialogue, which requires critical thinking, is also capable of generating critical thinking. Without dialogue there is no communication, and without communication there can be no true education" (p. 92). Thus, critical literacy is an essential component of dialogic spaces, and this now extends to digital environments, as it is imperative to recognize and address the ways that some voices are oppressed and others are privileged within those spaces.

Morrell (2015) grounded his studies of urban youth and digital media on critical literacy and views it as a means to "justify the use of popular culture in literacy education with urban adolescents" (p. 54). Critically participating in the cultural spaces in which youth operate can aid in the development of their literacies. Because digital spaces are undeniably prevalent in the popular cultures of youth, dialogically engaging in them warrants a focus on critical digital literacy (CDL) in a teacher's instruction (Garcia, Mirra, Morrell, Martinez, \& D'Artagnan, 2015). 


\section{Teacher Education, Teacher Development, and Digital Literacy}

A key component in the development of technology integration practices lies in preservice teacher education programs, where candidates can gain an understanding of literacy as it relates to digital environment practices, development of digital skills, and finally critical evaluation, the creation, and interpretation of meaning in digital environments. Preparing teachers through the development of their personal critical digital literacies can lead to instruction that is founded on sociocultural awareness and a critical understanding of social structures at work in digital environments (Song, 2016; Watulak \& Kinzer, 2013). If we, as educators, do not emphasize the importance of critical literacy as we introduce educational technologies into the classroom, we are not equipping students with the tools necessary to identify the roles that power and privilege may play in digital spaces.

The same can be said for developing the CDL of practicing teachers where the PD involving technology integration focuses on meaningful and critical digital literacy practices rather than on functional technology use (Serafini, 2012). Studies show that where educational technology is concerned, the short fix that is provided in a workshop does not translate to long term instructional implementation (Battersby \& Verdi, 2015; DuFour \& Mattos, 2013; Louis \& Wahlstrom, 2011). In fact, Darling-Hammond et al. (2009) explain that "While teachers typically need substantial professional development in a given area (close to 50 hours) to improve their skills and their students' learning, most professional development opportunities in the U.S. are much shorter" (p.5). This is especially concerning where new technology tools are being introduced, as the effective use of such skills takes practice (Liu, Tsai, \& Huang, 2015; Ruggiero \& Mong, 2016; Sutton, 2011; Tondeur, Van Keer, van Braak, \& Valcke, 2008; Topper \& Lancaster, 2013). In a 2013 report generated for the Center for Educational Development, 
Gulamhussein challenges the standard formats for teacher PD that are most prevalent: "the reason traditional professional development is ineffective is that it doesn't support teachers during the stage of learning with the steepest learning curve: implementation" (Retrieved from the Center for Public Education: http://www.centerforpubliceducation.org ). In addition, it is noted that “....mastery comes only as result of continuous practice despite awkward performance and frustration in the early stages...when teachers are coached through the awkward phase of implementation, 95 percent can transfer the skill" (Gulamhussein, 2013, p.37).

Understanding how both researchers and teacher educators are defining the digital literacies of pre-service teachers is an essential starting point. Current studies about technology integration show a functionalist approach to this topic, which has resulted in a quantitative valuation of technology integration practices. According to Edmonson (2002), functionalism "avoids ideological considerations (Marcuse, 1964), reflecting a positivist view that facts are separate from human values, thus avoiding explicit linkages between education and politics" ( $\mathrm{p}$. 113). An abundance of approaches to the study of technology integration practices of teachers focus on the superficial use of technology tools. This appears to have resulted from the increase in interest, internet access, and use by students, and expectations about technology integration by teachers in state and federal educational standards (Ball \& Forzani, 2011; Chen, 2010; Conley, 2011).

\section{The TPACK Framework}

One specific framework that is being used by researchers to examine teachers' technology integration practices is Mishra and Koehler's (2006) Technological, Pedagogical, Content area Knowledge (TPACK) framework. The importance that is placed on context in the TPACK framework can support the consideration of sociocultural and critical theories when 
studying the recruitment of that knowledge. While Koehler, Mishra, and Cain (2013) emphasized the consideration of context while applying their framework, it seems that researchers utilizing TPACK measurement tools for their studies are not paying heed. TPACK research focused solely on quantitative analysis reflects functionalism (Edmondson, 2002), as the complexities of the social and cultural contexts present in schools are not considered (examples of functionalist research include Chai, Koh, and Tsai, 2010; Hofer \& Grandgenett, 2012; Koh \& Divaharan, 2011; Schmidt et al., 2009; Young, Young, \& Shaker, 2012).

Johnson (2015) emphasized the importance of noticing what doesn't get noticed in educational technology research. He explained: "it appears that many researchers within ed-tech have been focusing on building the field up to be respected as a science, whereas in fact, when dealing with education, messy realities abound and we would do better to embrace complexity" (Johnson, 2015, p. 45). Understanding the social factors that influence and impact the digital environment is not wholly considered in a quantified valuation of an individual's technology integration practices. Factors such as the socioeconomic affordances, barriers that accompany technology use, and the presence of a hierarchy of ideologies that exist in the digital environment and how they impact the way students and teachers are able to represent themselves, develop knowledge and understanding, and operate in their best interests in that environment are not closely examined.

The TPACK framework may provide a strong beginning for understanding how teachers develop their technology integration practices. It is an attempt to connect pedagogy, technology and content "as they play out in in classroom context" (Koehler et al., 2013, p. 18). Koehler et al. (2013) explained that utilizing a TPACK framework requires recognition that "technology, pedagogy, and content do not exist in a vacuum, but rather, are instantiated in specific learning 
and teaching contexts" (p. 16). While context is referred to, pedagogical knowledge and practical application of critical theory within that framework is not specifically addressed. The application of a critical digital literacy framework can help ensure that teachers recognize the sociocultural contexts of digital environments and how they impact student exposure to, understanding of, and production of knowledge (Avila \& Pandya, 2013; Burnett \& Merchant, 2011; Song, 2016; Watulak \& Kinzer, 2013).

In consideration of this, I developed my study to fill this gap in the research in order to provide direction for teacher education programs and teacher development in order to develop graduate students' and practicing teachers' critical digital literacies (CDL). It is my hope that such development will lead to meaningful technology integration that includes CDL classroom practices. The purpose of this study is twofold. First, the objective is to gain an understanding of how graduate students believed they were prepared to meaningfully and critically integrate technology into their classroom practices. Second, the intent was to understand how graduate students who are practicing teachers recruited their CDL and TPACK into their actual classroom practices. This included gaining an understanding of what they believed led to their decisions surrounding technology integration and critical digital literacy (CDL) practices and any barriers and supports they may have encountered while teaching.

\section{Contributing Theoretical Frameworks}

My study and understanding of several literacy frameworks and theories informed the development of my own theoretical framework for this research. I drew on my understanding of New Literacy Studies (Street, 1998), Lankshear and Knobel's (2008, 2014) work in new literacies, research involving TPACK, and the Critical Digital Literacies framework. For this study, I intentionally drew from the foundational work of NLS, New Literacies, TPACK, and 
CDL to develop what I call a Critical Pedagogical Technological Content Knowledge (CTPACK) framework. While I acknowledge that the study of educational technology is full of guiding frameworks, I believe my addition is necessary as it more closely reflected my understandings and beliefs about meaningful and critical technology integration practices. This new framework is a valuable addition to the conversation about technology integration as it serves as a bridge connecting previous frameworks and approaches.

A C-TPACK framework contains several essential components. This framework prioritizes the recognition and critical analysis of the ideologies and social factors that are embedded in digital literacies; considers necessary the inclusion of new technologies in the understanding and valuing of the development of student literacy; recognizes the importance of connecting content, pedagogical, and technological knowledge to more meaningfully integrate technology; and values the participatory and collaborative practices of digital environments that contribute to student literacy. This C-TPACK framework contributed to the development of my research questions and methodology, and informed the analysis of data and interpretation of my findings.

\section{Street's New Literacy Studies and Lankshear and Knobel's New Literacies}

The New Literacy Studies (NLS) is considered a decidedly historical and sociocultural approach to understanding literacy (Gee, 2012a). Street (1984, 1998), an early developer and proponent of (NLS), explained that the framework gained attention because literacy practices seemed to be "developing and spreading in more complex ways, whilst educational and government discourse focuses on 'falling standards' and lack of literacy skills" (p. 1). Similar to the New London Group's multiliteracies approach (The New London Group, 1996), this led Street (1998) to consider the expansion of the traditional understanding of literacy to specifically 
include the social practices and resources that technology affords. Street understood literacy "in terms of concrete social practices and theorized it in terms of the ideologies in which different literacies are embedded" (Gee, 2012b, p. 76). Social factors such as political and economic conditions, social structure, and individual and group ideologies are considered as pivotal to the development of literacy in the NLS framework (Gee, 2012b). Lankshear and Knobel (2008) stated:

From a sociocultural perspective, these different ways of reading and writing and the 'enculturations' that lead to becoming proficient in them are literacies. Engaging in these situated practices where we make meanings by relating texts to larger ways of doing and being is engaging in literacy—or, more accurately, literacies, since we are all apprenticed to more than one. (p. 7)

With this statement, Lankshear and Knobel (2008) expressed the importance of a mindset that recognizes the value of different forms of literacy. To them, understanding literacy necessitates consideration of all elements as to how and where people make meaning about reading and writing. Accepting that learning that takes place through the use of technology pushes educators to consider media "not in terms of their surface features but in terms of their underlying structure and the causal mechanisms by which they might interact with cognitive and social processes" (Kozma, 1994, p. 11).

Like the New London Group's (1996) work in multiliteracies, the NLS framework challenges the traditional definition of literacy. The challenges cited by Street (1998) include the notion of a standard language that potentially alienates those not adhering to the dominant discourse that is pushed in the standardization process. In addition, a traditional literacy definition does not wholly consider the impact on student literacy practices of the discourses that 
students engage in outside of schools and the "non-traditional" communication channels used for such discourses.

Street (1998) suggested that the politics and economics of education are standing in the way of broadening this definition. He claimed that the push by corporations stemming from the Total Quality Management (TQM) movement, whereby quality of products are controlled through imposing "reductionist and unitized notions of measurement and of quality" (p. 6), bled into the educational sector and have been reflected in the standardization of language. Using The National Literacy Strategy requirements as his example, Street (1998) pointed to the necessity of critical analysis of texts and suggested that defining student literacy without such analysis comes at the expense of representation of cultural and linguistic diversity as texts "may serve to impose and constrain meanings" (p. 7). He proposed that educators can rectify this through the use of the NLS lens.

Building on Street's work, Knobel and Lankshear (2014) also believed that the NLS framework acknowledges sociocultural influences that occur both in and out of school. Their new literacies concept was developed in an attempt to more specifically understand the role of new technologies in student literacy. Proponents believe that the incorporation of a New Literacies framework can aid educators in determining how to prepare students for effectively operating in the digital environments they are facing and will continue to face in the future (Knobel \& Lankshear, 2014; Leu, Kiili, \& Forzani, 2016).

To this end, Knobel and Lankshear (2014) stated that their new literacies theory included two dimensions, new "technical stuff" and new "ethos stuff," that dynamically inter-relate to form literacy practices. New "technical stuff” referred to the shift in texts from a material analogue format to a digital format. The digital format allowed for a more far-reaching and 
immediate form of communication and representation (Knobel \& Lankshear, 2014). "Ethos stuff" referred to the "intensely participatory, collaborative, and distributed nature of many current and emerging practices within formal and non-formal spheres of everyday engagement" (Knobel \& Lankshear, 2007, p. 227). The culture that results from educators practicing a new literacies approach as a guide for understanding student literacy is strongly participatory and collaborative (Knobel \& Lankshear, 2014). When the technical combines with the ethos, these new literacies represent "social practices that are mediated by digital technologies" (Knobel \& Lankshear, 2014, p. 98).

Lankshear and Knobel (2007) explained the value of educators seeing and utilizing technology as a literacy tool:

...(it) largely has to do with how it enables people to build and participate in literacy practices that involve different kinds of values, sensibilities, norms and procedures from those that characterize conventional literacies. (p. 224)

They claimed that in schools, traditionally defining literacy requires students to engage in academic language that aligns with a specific and predetermined sociocultural background, making the dialogue one that privileges those who identify with that academic or specialized language. Educators that recruit a new literacies approach provide opportunities for students to make meaning through the use of a multitude of communications channels which can lead to the development of literacy practices that are more personally representational. A key component of recruiting this framework is understanding that meaning-making involves critical reflection about the discourses that are being used and about who and what they represent.

Knobel and Lankshear (2014) viewed "new ethos" as being generated on a macro scale where technological advancements, economies, culture, and epistemology are all influencing 
literacy practices. The new literacies approach emphasizes the social, cultural, and historical practices of communities. Knobel and Lankshear (2014) explained that educators using this lens "develop practices that involve bringing technology, knowledge, and skills together within the contexts of social purpose" (p. 98).

In their research, Draper and Wimmer (2015) studied the role that new literacies play in understanding teachers' approaches to content area. They explained that it provided a way for educators to understand student literacy as "social practices that continuously evolve due to technological advances. These practices allow students to question, construct, and participate in consuming and producing knowledge through multiple modes of text including image, sound, and gesture" (Draper \& Wimmer, 2015, p. 253). Gee (2012a) explained that "new literacies is about studying new types of literacy beyond print literacy, especially 'digital literacies' and literacy practices embedded in popular culture" (p. 371).

The NLS framework looks at literacy from a sociocultural perspective (Street, 1998). Lankshear and Knobel $(2007,2014)$ incorporated the NLS approach as they referred to literacies that develop in digital environments, and those environments are socially constructed spaces. Operating in digital environments can lead to the development of what Lankshear and Knobel (2008) called new literacies or "new technology-mediated literacy practices" (p. 29).

Importantly, like Street, they consider and emphasize understanding the social, cultural, and ideological contexts within which these new literacies are developed which pushes past a functionalist understanding of technology use in educational settings.

\section{Framework}

Digital environments can offer opportunities for discourse where ideally, there would be freedom for reflection and action of all participants to create and/or recreate meaning and 
understanding of knowledge. Those environments could potentially provide dialogic opportunities where "the reading and the rereading of the word and the world" (Freire \& Macedo, 1987, p. 2) and critical thinking take place (Freire, 1970). With the increasing presence of digital environments as places of discourse, critical literacy can be extended to digital environments. However, it is imperative to recognize and address the ways that some voices are oppressed and others are privileged within those spaces.

Watulak and Kinzer (2013) explained that CDL emphasizes engaging in the social and cultural contexts of technology use where critical analysis and critical reflection of content are practiced. In addition, within digital environments there is both consumption and production of knowledge. Importantly, CDL promotes a democratic approach to media where critical analysis of content and context join with the creation and design of new content that represents a student's voice (Burnett \& Merchant, 2011; Garcia, 2013; Handsfield, Dean, \& Cielocha, 2009; Watulak \& Kinzer, 2013). Pangrazio (2016) explained that a CDL framework is a strong means for approaching an understanding of what is involved in the design of meaning-making through the creation and use of digital texts. She stated that a CDL approach is the "unpacking and examining the processes of digital design in an educational setting [which] lead the learner to a critical and practical knowledge of digital text production" (Pangrazio, 2016, p. 166).

\section{Understanding meaning, context, and value.}

The CDL framework originated from the Multiliteracies and New Literacies frameworks. Pangrazio (2016) explained that while these (Multiliteracies and New Literacies) frameworks do include an emphasis on critical evaluation of the situated practices, products, and meanings that are generated in digital media, they fail to address what is specifically distinct about and manifested in the digital context. She suggested that it is a CDL framework that incorporates this 
component in that it focuses on "the outcomes of making, creating and producing, and it provides an avenue for individuals to express their ideas, values, beliefs" (p. 165). To that end, Watulak and Kinzer (2013) defined a CDL framework as encompassing four main elements, which include: "understanding cultural, social, and historical contexts of technology use; critical thinking and analysis; reflective practice; and facility with the functional skills and tools of digital technology production (p. 128).

As explained earlier, researchers using these lenses are considering digital literacies to extend beyond the development of a specific set of technological tools (Jones \& Hafner, 2012; Lankshear \& Knobel, 2014; Moran, Seaman, \& Tinti-Kane, 2011; Stornaiuolo \& LeBlanc, 2016; Street, 1998; Watulak \& Kinzer, 2013). This includes the critical ability to develop knowledge and represent oneself; understand, navigate, and create within the social structure of the digital environment; and recognize the positions of power at work in that environment and how that power structure impacts each individual. If critical literacy is not incorporated into the development of digital literacies, we risk landing on the historical continuum where literacy has been used to "solidify the social hierarchy, empower elites, and ensure that people lower on the hierarchy accept the values, norms, and beliefs of the elites" (Gee, 2012b, p. 57).

The application of a CDL framework shows an understanding of the affordances and constraints of digital media and how to adapt to circumstances and contexts based on this understanding. Jones and Hafner (2012) explained that developing digital literacies means using technology to "do something in the social world and these things we do invariably involve managing our social relationships and our social identities in all sorts of different and sometimes unpredictable situations" (p. 13). This approach prioritizes the participatory and collaborative nature of digital environments. Meyers, Erickson, and Small (2013) proposed that utilizing a 
framework that encompasses technology skills development, cognitive processing, and consideration of context can provide the strongest way for educators to understand the digital literacies of students. The CDL framework fits those parameters.

When educators recruit CDL practices, they help to ensure that students are critically navigating the information that is at their fingertips in this digital age. This is essential if all students are to have equal opportunity to express and represent themselves through the use, interpretation, and creation of texts offered in digital spaces. In addition, consideration of the moving parts of digital literacies reflects a critical look at the power and ideologies at work as students learn in technologically integrated spaces. Accepting the learning that takes place through the use of technology shows consideration of media "not in terms of their surface features but in terms of their underlying structure and the causal mechanisms by which they might interact with cognitive and social processes" (Kozma, 1994, p. 11). As some students are restricted within digital environments, those restrictions impact their literacy practices. Prioritizing critical theory in the valuation of students' and teachers' digital literacies can help ensure that digital environments are learning spaces where equity takes precedence. This supports Erstad's (2012) proposal that:

In a complex world with many media, analogue and digital, embedded in different cultural practices, we need to develop ways of researching this cultural complexity to grasp fully the role of media among young people and also how we understand young people's engagement in learning and education. (p. 25)

For equitable representation of individuals in digital environments, a critical theoretical lens is a key component and is prioritized in my framework. This understanding of the importance of critical theory and its inclusion in the development of a student's digital literacy 
provide a means for countering the neutrality that is inherent in a positivist approach to education (Giroux, 2009).

Critical digital literacy practices provide the best chance for future teachers to be able to develop a democratic learning environment that both recognizes the cultural relevance of digital spaces in the lives of students and promotes equity within those spaces. Giroux (2009) explained that all people "...need to affirm their own histories through the use of a language, a set of social relations, and body of knowledge that critically reconstructs and dignifies the cultural experiences that make up the tissue, texture, and history of their daily lives" (p. 47). There is opportunity to achieve this through technology integration in our schools through the guidance of educators who have had opportunity to develop their own critical digital literacies.

As discussed earlier, there is no denying that students are choosing to express themselves and develop their identities through the use of online spaces (Leinhart, 2015). A CDL framework in research and teacher practices surrounding educational technology is essential, as it promotes and prioritizes student voice and empowerment which led me to recruit a CDL Framework when thinking about the incorporation of technology into teaching practices. My understanding of the value and importance of a CDL lens led me to develop research questions that examine how graduate students believe they are prepared to incorporate CDL into their teaching practices as well as how their beliefs translate to classroom practices. The findings from this study will provide a stronger understanding of how best to prepare pre-service and practicing teachers to meaningfully integrate technology in representative and equitable ways.

\section{Technological, Pedagogical, Content Knowledge (TPACK)}

While the earlier presented frameworks provide lenses for educators to understand how new technologies and digital media impact student literacy, the Technological, Pedagogical, 
Content area Knowledge (TPACK) framework provides a means for understanding how preservice teachers (graduate students) and practicing teachers develop knowledge of digital literacy and teaching. During a time of high-stakes accountability in our education system where curriculum is shaped by standards that include the critical integration of technology, researchers recognize the challenges that higher education educators are facing about how to develop teacher digital literacy (Darling-Hammond, 2012; Hofer \& Grandgenett, 2012; Kozma, 2011; Niess, 2011).

Echoing some of the core components of earlier described frameworks, the TPACK framework supports the consideration of context and situated practice when defining digital literacy. This framework is structured to explain and connect pedagogy, technology and content "as they play out in classroom context" in teacher education programs (Koehler, Mishra, \& Cain, 2013, p. 18; Davies \& West, 2014). Koehler, Mishra, and Cain (2013) explained that utilizing a TPACK framework requires recognizing that these "do not exist in a vacuum, but rather, are instantiated in specific learning and teaching contexts" (p. 16). While context is referred to in the TPACK framework, pedagogical knowledge and practical application of critical theory are not specifically addressed.

\section{Origins of TPACK.}

The TPACK framework builds on the earlier work of Shulman (1986). Rather than focusing on developing content and pedagogical knowledge in isolation, Shulman (1986) argued that “.... a teacher's understanding of how to bring together his or her content and pedagogical knowledge is the key to effective teaching practice" (p. 84). The acronym "PCK," stands for pedagogical content knowledge, and represents Shulman's (1986) framework that seeks to explain and promote a teacher's success in the classroom. Niess (2011) described the origin and 
evolution of TPACK by comparing it to the development, understanding, and acceptance of the PCK framework. TPACK appears to be emerging in much the same way as PCK. Each step in the process of the development of the PCK framework led to a clearer understanding of that model, which researchers now widely use in the area of teacher education. Hofer and Grandgenett (2012) explained that:

It is in this intersection of content and pedagogical knowledge that teachers are best able to anticipate students' learning needs for a particular topic or concept, select the optimal instructional approach(es), and understand how to scaffold the learning experience for students. Since the development of the PCK framework, many teacher education programs have been redesigned to assist teacher candidates in developing their PCK through content-specific methods, planning, and field experience coursework. (p. 84) This provides support for Shulman's (1986) explanation that the most effective teachers are those that understand how pedagogy and content relate and connect. With the inclusion of technology in the national standards currently shaping teacher education programs, researchers are exploring how technology knowledge can partner with content and pedagogical knowledge to ensure preservice and practicing teachers are prepared to integrate technology (Harris \& Hofer, 2014, 2017). Niess (2011) proposed that the emphasis on technology in national standards dictates the need to develop teacher technology knowledge, and supports the consideration of redesigning teacher education coursework to reflect a Technological Pedagogical Content Knowledge (TPACK) approach. Hofer and Grandgenett (2012) stated that, in the time between the conception of the PCK framework and today, technology knowledge has expanded dramatically. They agreed that the burgeoning presence of technology necessitates inclusion of technology knowledge (TK) when looking at how best to educate teachers. 


\section{Implementation of TPACK in research.}

Niess (2011) explained that the implementation of a TPACK framework will help students realize the value of technology as a learning tool that can be applied throughout curriculum. As a theoretical framework, TPACK appears to allow for the dynamic nature of technology knowledge by connecting it to the content and pedagogical foundational knowledge

of preservice and practicing teachers (Harris \& Hofer, 2014, 2017; Niess, 2011). Koehler and Mishra (2009) explained that:

The TPACK framework seeks to assist the development of better techniques for discovering and describing how technology-related professional knowledge is implemented and instantiated in practice. By better describing the types of knowledge teachers need (in the form of content, pedagogy, technology, contexts and their interactions), educators are in a better position to understand the variance in levels of technology integration occurring. (p. 67)

The originators of the TPACK view understanding the variances as the goal, and created an approach that requires valuing each factor within the framework that contributes to the end knowledge. With this in mind, researchers have begun to try to measure the TPACK of educators in an attempt to predict technology integration in their future classrooms. However, the measurability of such a complex system of knowledge has not proven easy.

\section{Missing component in research on TPACK.}

The TPACK framework appears to stop short of including critical theory as a relevant and valued component of developing the digital literacy of students. While Koehler et al. (2013) emphasized the consideration of context while applying their framework, it seems that researchers utilizing TPACK measurement tools for their studies are not paying heed. Factors 
such as the socioeconomic affordances, barriers that accompany technology use and the presence of a hierarchy of ideologies that exist in digital media and how they impact the way students and teachers are able to represent themselves, develop knowledge and understanding, and operate in their best interests in that environment are not closely examined (Chai et al., 2010; Hofer \& Grandgenett, 2012; Koh \& Divaharan, 2011; Schmidt et al., 2009; Young, Young, \& Shaker, 2012). The application of a CDL lens in conjunction with the TPACK framework could help ensure that teachers recognize the socio-cultural context of digital environments and how context impacts student exposure to and understanding of knowledge.

\section{The Role of Critical Literacy Frameworks in TPACK}

As explained earlier, the TPACK framework specifically provides a lens for understanding how preservice teachers (graduate students) and practicing teachers develop digital literacy. Because the TPACK Framework supports the consideration of context and situated practice when defining digital literacy and is structured to explain and connect pedagogy, technology and content "as they play out in classroom context" in teacher education programs (Koehler et al., 2013, p. 18; Davies \& West, 2014), it provided me with additional valuable perspective. In their proposal of the TPACK framework, Mishra and Koehler (2006) spoke about this "context" as including consideration of theory when researching and studying the technology integration practices of teachers. Specifically, they cited the work of Selfe (1990) who stated that a theoretical perspective is necessary, otherwise the result will be research that "constrains our current educational uses of computers" and "seriously limits our vision of what might be accomplished with computer technology in a broader social, cultural, or educational context" (p. 119). 
While Mishra and Koehler emphasized the importance of studying teachers in their classroom context in a traditional sense (i.e. within the walls of that classroom), in the case of teachers engaging in technology use in their practices, this classroom context extends to digital environments, and as such, the critical contexts that teachers and students encounter in those spaces needs to be considered (Serafini, 2012; Watulak \& Kinzer, 2013). Morrell (2014) explained that "research should exist as a dialectic interaction between existing theories and contemporary experience" (p. 8). With the increasing presence of online spaces in contemporary classrooms, teachers and students are experiencing the power structures and dominant discourses that are promoted in digital classroom contexts. Including the addition of a CDL component to the TPACK framework both addresses this need to expand the understanding of classroom contexts and contributes to the theoretical dialogue surrounding the increasing use of digital environments in classroom practices and the accompanying need to consider critical literacy practices in those contexts.

The above theories and frameworks that I drew on for my own theoretical framework provided definitional clarity about operating in digital environments, the consideration of the social, historical, and contextual impacts of operation within digital spaces, and examination of the literacies that I believe are necessary for successful technology integration. I believe the TPACK framework has something different to offer. This framework specifically addresses the relationship of an educator's technology integration practices to his/her content knowledge and pedagogical beliefs. Importantly, the TPACK framework connects pedagogy to technology, and past studies have begun to move the discussion about educational technology past the theoretical and into the classroom. 
This is a necessary component of my framework for this study as I am seeking to understand how graduate students' beliefs and educational experiences are recruited into classroom practices. As Hofer and Grandgenett (2012) explained, TPACK is “...the domain of knowledge where all the forms of a teacher's knowledge intersect. This is the form of knowledge that is required to plan and implement successful technology-infused learning experiences" ( $p$. 86). This understanding supports my own; however, I do believe it is necessary to take it a step further.

\section{Measuring TPACK.}

The inclusion of a CDL lens may provide a crucial missing component in the TPACK framework. In their development of the TPACK framework, Koehler et al. (2013) did place importance on context which does support the potential application of both sociocultural and critical theory when determining digital literacy. However, the TPACK evaluation tools largely do not consider these components in the measurement of a graduate student's and teacher's TPACK. In addition, while these tools provide predictive information, studies typically stop short of considering how graduate students and teachers recruit TPACK in classroom practices.

While I consider the TPACK framework a strong guide in the development of this research study, I believe its application necessitates a partnering with the CDL framework to more accurately represent the importance and impact of the socio-cultural contexts that exist in digital spaces. Additionally, TPACK measurement information becomes more valuable when compared to subsequent graduate student and teacher practices as data from multiple sources (lesson plans, observations, and interviews) can be used in combination resulting in a richer understanding. Below, I present the C-TPACK framework that adds CDL as a necessary 
component in the "dynamic equilibrium" (p. 67) that Koehler and Mishra (2009) originally presented for the seven knowledge domains of the TPACK framework.

\section{Locating the "C" in the C-TPACK Framework}

The social contexts where technology use takes place impact people's literacies. As some students are restricted within digital spaces, those restrictions impact their literacy practices. Consideration critical theory as elemental to digital literacies allows for a critical look at the power and ideologies at work as students learn in technologically integrated spaces. If we look only to numbers and predictive studies of preservice teachers, it is difficult to know whether teachers are critically navigating with technology and moving from using technology as enhancement toward meaningful, transformative applications. Examining a teacher's reflective and reflexive practices involved in their decisions about integrating technology is needed to understand that teacher's process for recruiting C-TPACK.

The C-TPACK theoretical framework prioritizes critical theory in the valuation of students' and teachers' digital literacies to ensure that digital environments are learning spaces where equity takes precedence. This study provided an opportunity to explore graduate student technology integration beliefs and critical digital literacies and examined how they were recruited into classroom practices. Erstad (2012) proposed that:

In a complex world with many media, analogue and digital, embedded in different cultural practices, we need to develop ways of researching this cultural complexity to grasp fully the role of media among young people and also how we understand young people's engagement in learning and education. (p. 25) 
My hope is that this study will provide valuable information for teacher education and teacher development programs that will lead to meaningful, critical technology integration practices in future classrooms.

\section{Summary}

My research objectives included: gaining an understanding of how graduate students believed they were prepared to meaningfully and critically integrate technology into their classroom practices; understanding how graduate students recruited their TPACK in their preparations and instructional classroom practices; and learning what graduate students believe led to their decisions surrounding technology integration and critical digital literacy (CDL) practices including any challenges they faced when teaching. These objectives led me to review literature that addressed the topics of CDL, the representation of individuals in digital spaces, and the TPACK framework.

With these objectives in mind, I developed the following research questions for this study.

RQ1: What is the critical, technological, pedagogical and content area knowledge of graduate students in one university's School of Teaching and Learning?

RQ2: How does a subset of these graduate students who are also practicing teachers recruit their C-TPACK into their planning and instruction (i.e. their practices)?

RQ3: What does this same subset of graduate students/practicing teachers identify as the contributing factors that supported or hindered their abilities to engage the critical dimensions in their teaching?

These research questions guided my approach to the literature. 


\section{Terminology}

Critical Digital Literacies (CDL): CDL extends beyond the development of a specific set of technological tools. It includes the ability to develop knowledge and represent oneself;

understand, navigate, and create within the social structure of the digital environment; and recognize the positions of power at work in that environment and how that power structure impacts each individual. Watulak and Kinzer (2013) define CDL as encompassing four main components: "understanding cultural, social, and historical contexts of technology use; critical thinking and analysis; reflective practice; and facility with the functional skills and tools of digital technology production (p. 128).

Digital environments: Digital environments are online domains, accessed via the internet, that provide opportunities for representation and the retrieval and contribution of information.

Meaningful technology integration: The incorporation of digital environments into instructional practices where social factors, ideologies, political and economic conditions, and cultural and historical contexts are considered.

Social media/Social network sites: As defined by Mao (2014) social media is “...new technologies and applications that utilize the Internet and Web 2.0 technologies and allow users to create and participate in various communities through functions such as communicating, sharing, collaborating, publishing, managing and interacting” (p. 213). The terms social media and social network platforms/sites (SNS) will be used interchangeably.

Superficial technology integration: The functionalist use of digital tools without consideration of context, social factors, political and economic conditions, and cultural and/or historical contexts within which content is delivered via digital platforms. 


\section{CHAPTER II: LITERATURE REVIEW}

As explained previously, I have a strong interest in understanding educators' CDL and how that is recruited into their educational technology integration practices in their classrooms. Previous research, reviewed below, has shown that examining a teacher's TPACK can provide a means for predicting such practices. It is possible that the most meaningful technology integration practices would incorporate CDL to ensure that all students are empowered and represented in those digital environments. These considerations led me to examine the literature to identify empirical studies that specifically addressed the TPACK of graduate students and practicing teachers, as well as empirical research that examined the technology integration practices of graduate students and/or practicing teachers that utilize a CDL Framework. While my study focused on graduate student practicing teachers, I recognized early in my review of previous research that due to the limited studies focused on TPACK for that population, I needed to include TPACK studies of preservice middle and high school teachers as well to be fully aware of the methods and findings that already existed. As Phase 2 of my study focused on graduate students who are practicing teachers, this made sense. Finally, to ensure consideration of the most recent research in these areas, and because of the deictic nature of technology (Leu, Kinzer, Coiro, \& Cammack, 2004), my review primarily focused on studies that have been conducted in the past ten years.

I also reviewed research about how critical theory has been incorporated into studies that consider the development of digital literacies. Specifically, I focused on studies that examined the role of CDL in the online practices of graduate students (which again, extended to include studies of pre-service teachers for reasons noted above), and middle and high school students and 
teachers in educational settings. This review of literature of empirical studies that examined the application of CDL of graduate students and practicing teachers as they integrated technology revealed an almost exclusive focus by the researchers on how CDL is applied to social network platforms (SNS) for educational purposes. Given the ubiquitous presence of social media in the lives of middle and high school students, this was not surprising.

\section{Technological Pedagogical Content Knowledge (TPACK) Studies}

The TPACK framework is being seriously considered by researchers and practitioners alike, as it attempts to describe the complex relationship between technology, pedagogy, and content knowledge. The interconnections of these forms of knowledge are being studied to determine how best to prepare preservice teachers for the technology integration that is required by national standards. Attempts to quantify the TPACK of individuals are being made, but there is concern about the ability for a measurement instrument to capture the complexities within this framework. Researchers recognize the potential value of framework, but propose continued exploration of examining how to determine how a teacher's TPACK is recruited into classroom practices.

In an extensive review of TPACK studies, Niess (2011) honed in on a key finding: that the emphasis should be placed on the importance of technology not as a supplement to teaching and learning, but as a component of teaching and learning. Through the creation and continued development of a model for measuring the TPACK of preservice teachers, Koh and Divaharan (2011) examined the stages of technology integration in which students engaged in a seven-week teacher education course in Singapore. The use of pre-study and post-study surveys, and reflections at the end of each of three phases of instruction, allowed the authors to analyze how the students' TPACK knowledge advanced. The findings indicated that through faculty 
modeling, hand-on experience, and design-projects, preservice teachers significantly developed their TPACK. These authors were unable to offer statistical analysis of their data to show reliability and validity of their process.

Regardless of the admitted limitations, Koh and Divaharan (2011) contended that their study aided in identifying a direction for future TPACK research. Wetzel, Buss, Foulger, and Lindsay (2014) agreed, and referred to Koh and Divarharan's (2011) study as their benchmark. They suggested that the complexities of the domains lay in the differing amounts of knowledge each preservice teacher had previous to the study, which has not previously been considered in the research. This observation echoed Pamuk's (2012) findings. Specifically, these researchers explained that a preservice teacher may have limited Pedagogical Knowledge (PK) due to not having studied and developed that knowledge set yet. Chai et al. (2010) also emphasized the importance of a preservice teacher's PK and stated: “...increasing PK is foundational for developing TPACK. As preservice teachers develop a basic level of PK, they establish a strong knowledge base from which effective technology integration ideas can flourish" (p. 69). Using a regression model to analyze their data, they proved that a preservice teacher's TK is strengthened when that teacher's PK is advanced (Chai et al., 2010). Pamuk (2012) expanded upon this finding by proposing the inclusion of classroom experience, which he believed affected a preservice teacher's ability to recruit TPACK gained into technology integration.

A teacher's personal learning style and choice of teaching practices impact his/her decisions about the role technology will play in his/her classroom (Anderson, Groulx, \& Maninger, 2011; Koehler and Mishra, 2009; Koh, Chai, \& Tsai, 2014; Prestridge, 2017; Tondeur, Kershaw, Vanderlinde, \& Van Braak, 2013). Such choices are often made early on in teacher education programs when preservice teachers are not often exposed to modeling of 
content area technology integration (Goktas, Yildrium, \& Yildrium, 2009; Sutton, 2011) which makes teacher education courses pivotal in the development of teaching and learning beliefs that support technology integration. Explicit belief exploration (Pedagogical Knowledge) coupled with technology practices that enrich the curriculum and transform teaching and learning has been shown to lead to higher levels of integration (Ertmer, Ottenbreit-Leftwich, Sadik, Sendurer, E., \& Sendurer, P., 2012; Koh et al., 2014; Overbay, Patterson, Vasu, Grable, 2010; Prestridge, 2017; Ruggiero \& Mong, 2015).

While teacher education coursework may be pivotal, there is value in understanding how pre-service teachers may have been informed by dominant ideologies regarding teaching, learning, and using technology before entering teacher education programs. This circles the discussion back to the importance of studying the C-TPACK of practicing teachers. Where TPACK research does not direct attention to the critical component of beliefs about and practices with technology, C-TPACK does.

Once students become practicing teachers, the continuing education of teachers regarding the connection between and recruitment of the knowledge domains of TPACK shifts to professional development (PD). Modeling, again, has an impact here as a teachers reflect about their pedagogical beliefs and how those beliefs align with technology practices when exposed to others who are effectively embracing and practicing technology integration that resulted from such reflection (Ertmer et al., 2012; Ruggiero \& Mong, 2015). Liu, Tsai, and Huang (2015) explained that teachers who observed other educators successfully adopting and integrating technology both increased the likelihood that they will integrate it, and also resulted in improvement of teaching methods. This collaboration between teachers modeling technology use and those considering its use is invaluable in the push for integration (Tondeur, et al., 2013). 
There is strong evidence that the presence of a mentor or instructor who models effective instructional technology integration practices can lead other teachers to integrate particularly in a one-to-one lap top environment (Cooper, 2015; Stanhope \& Corn, 2014; Udesky, 2015).

Chai et al. (2010), Koh and Divarharan (2011), Pamuk (2012), and Wetzel et al. (2014), all used questionnaires/reflections and surveys as their means of data collection. In fact, those measurement instruments are used most often utilized in previous TPACK studies. There is little mention of direct observational data in the studies where TPACK is considered, which indicates a gap in the literature. Such observation data could be helpful in more specifically determining the degree of each TPACK component that a preservice teacher possesses (Archambault \& Barnett, 2010). Cuban (2009) emphasized the importance of observing teachers in context. He explained that observing teacher actions in the classroom setting is necessary to understand the entirety of a teacher's decisions about how technology is incorporated. Patton (1999) also explained the value of different forms of data collection: "Different kinds of data may yield somewhat different results because different types of inquiry are sensitive to different real world nuances" (p. 1193). Utilizing different forms of data collection can create “...opportunities for deeper insight into the relationship between inquiry approach and the phenomenon under study" (Patton, 1999, p. 1193).

Chai et al. (2010) analyzed how pre-service teachers join their pedagogical, content, and technological knowledge both before and after participating in a pre-service, teacher education course on information and communication technology (ICT). Their purpose was to determine the effectiveness of their course via data analysis of pre and post course student surveys. Chai et al. (2010) suggested that their results support a TPACK teacher education approach that could lead to technology integration in pre-service teachers' future classrooms. The graduate students who 
were studied were also enrolled in other courses that the authors explained may have contributed to an increase in their content knowledge, which is concerning. Because content knowledge was identified as a component of pre-service teacher TPACK, it was not convincing that the authors were able to control for the content knowledge variable when measuring the TPACK of the graduate students. This speaks to the complexity of the relationships between the types of knowledge that researchers are attempting to measure as a whole, rather than independently.

\section{Theoretical Foundations of TPACK Research}

In 2014, the same three authors published a study that more specifically analyzed the role that constructivism played in the development of teacher TPACK (Koh, et al., 2014). Their findings supported a constructivist approach to TPACK for teacher professional development. The authors believed their study has value, but they explained that the validity of the survey instrument was not known. Consequently, both Koh et al.'s (2014) and Chai et al.'s (2010) TPACK studies showed issues with finding a reliable means for data collection, analysis, and measurement of results.

Other studies that focused on the pedagogical beliefs of teachers and the relation to technology integration produced findings that support Koh et al.'s (2014) study. Researchers found that a teacher with constructivist pedagogical beliefs is more likely to integrate technology than one with traditionalist pedagogical beliefs (Ertmer 2005; Ertmer, \& Ottenbreit-Leftwich, 2013; Prestridge, 2017) which could lead to development of a teacher's TPACK (Koh et al., 2014). Bhattacharjee (2015) defined constructivism as beliefs and methods that support students individually "constructing their own understanding and knowledge of the world through experiencing things and reflecting on those experiences" P. 65). This meaning-making is accomplished when students "make a deliberate effort to make sense of the information that 
comes to them. They must own it. They must manipulate, discover, and create knowledge to fit their belief systems" (Bhattacharjee, 2015). Teachers who have constructivist beliefs about teaching and learning prioritize connecting previous knowledge with new knowledge, provide opportunities for students to work together to understand concepts, and incorporate authentic experiences where the knowledge can be applied (Bhattacharjee, 2015; Good \& Brophy, 1994).

In their study of graduate students, Paratore, O’Brien, Jimenez, Salinas, and Ly (2016), utilized mixed methods that incorporated measurement of graduate student TPACK in conjunction with direct technology integration instruction in a required technology integration teacher education course. They examined graduate student perceptions about their personal knowledge of technology, the usefulness of technology in practice, and the ways to incorporate technology to advance student literacy (Paratore, O’Brien, Jimenez, Salinas, \& Ly, 2016). Paratore et al. (2016) explained that their study sought to determine how best to prepare teachers to meaningfully integrate technology in ways that specifically advance student literacy practices. They found that by emphasizing content area technology integration, graduate students' perceptions of themselves as effectively utilizing technology became more positive.

\section{Measuring TPACK}

TPACK continues to prove difficult to measure. Models and survey instruments have been used, but little progress has been made in measurement instrument design that has provided reliable and valid results. Niess (2011) and Schmidt et al. (2009) contributed to the development of surveys as a means for evaluation of a preservice teacher's TPACK. Their surveys continue to be used, although modifications to those surveys are continually occurring, and the results are not always considered reliable. Archambault and Barnett (2010) examined this difficulty in their research. They conceded that in the academic arena, there is great appeal to TPACK 
(Archambault \& Barnett, 2010). However, the authors explained that while the value of the framework was widely recognized in the educational technology research arena, there continued to be concerns about the ability of a measurement instrument that can capture the complex relationships between a teacher's technological, pedagogical, and content knowledge (Archambault \& Barnett, 2010). As with other research results, Archambault and Barnett's (2010) findings explained that “...the TPACK domains do not statistically distinguish themselves..." (p. 1660). Such studies showed a continuing concern about the TPACK construct as a measuring and predictive tool for teacher technology integration largely due to the reliability and validity issues.

Adding to the complexity of the TPACK framework, its application, and its measurement, is a concern about teacher educator technology skill sets. Utilizing this framework in teacher education programs assumes that teacher educators have personal technology knowledge. In their study, Foulger, Buss, Wetzel, and Lindsey (2012) found that "Instructors who teach science, social studies, mathematics, and language arts methods courses may not be experts in teaching about technology integration. Even if content instructors teach with technology, they may not be capable of teaching preservice candidates how to teach in PK-12 classrooms with technology" (p. 49). This is a potential barrier for teacher education programs adopting the TPACK framework across teacher education curriculum.

While not focusing on teacher educators, Sutton's (2011) study lent credence to Foulger et al.'s (2012) findings. She explained recurring themes that her instrumental case study uncovered. Using guidelines from the International Society for Technology Education (ISTE), her study showed: “(a) a disconnect between preservice teachers' technology training and other aspects of their professional education, (b) a lack of content-area relevance, and c) inadequate 
retention and transfer" (p. 43). Sutton (2011) attributed these findings to teacher educators who lacked the technology skills that are needed to model and teach about the connection between technology knowledge and content knowledge. This led to an inability for preservice teachers' technology skills to match the ISTE guidelines. Teacher candidates and graduate students having limited exposure to practicing teachers who are implementing and modeling technology integration in the field is a noted concern in the research. Students surveyed about teacher education programs did not feel they had seen enough real classroom application of technology, and that affects their own instructional technology integration practices (Goktas, et al., 2009; Ruggiero \& Mong, 2015; Sutton, 2011; Topper \& Lancaster, 2013). Researchers recognized the importance of a preservice teacher's view of self-efficacy regarding the use of technology and believed that those beliefs factored into whether that teacher would integrate technology as a practicing teacher (Banister \& Reinhart, 2012; Chen, 2010; Duffin, French, \& Patrick, 2012; Holzberger, Philipp, \& Kunter, 2013). Bandurra (1977) explained:

Once established, enhanced self-efficacy tends to generalize to other situations in which performance was self-debilitated by preoccupation with personal inadequacies...As a result, improvements in behavioral functioning transfer not only to similar situations but to activities that are substantially different from those on which the treatment was focused. (p. 195)

Chai et al. (2010) agreed, and stated that: ...many studies have also found that teachers with high levels of confidence in their computer skills tend to use more technology in the classroom. A high level of TK may be 
important for developing TPACK. But, the relative influences of PK and CK have not been studied. (p65)

Koh and Divaharan's (2011) study also indicated that improved self confidence in TK, is likely to increase the chances for technology integration. Sutton's (2011) research also presented the value of self-efficacy where technology use is concerned. She claimed that ...the majority of the participants in this study perceived that they did not receive sufficient hands-on technology training throughout their program, and, as a result, many of the teachers in this study expressed feelings of inadequacy with regard to technology integration. (Sutton, 2011, p. 45)

In those studies, it was clear that self-efficacy beliefs were something the researchers believed could be developed through continued exposure to technology integration in all teacher education coursework. However, it is the measuring of this sense of self-efficacy that contributes to the complexity of determining a teacher's TPACK. As self-efficacy is a personal belief, this makes it difficult to uniformly quantify (Banister \& Reinhart, 2012). This poses a problem of determining the degree to which that factor plays in the TPACK framework and consequent technology integration.

Regardless, knowing that self-efficacy plays a role in a graduate students' technology integration is significant. It points to the necessity for teacher education and development programs to ensure preservice teachers have confidence in their ability to continue to integrate once they enter the field of education as practicing teachers. At the same time, these studies point to the need for ways to understand and examine that belief and its role in TPACK that do not only rely on quantification tools. 


\section{Concerns about TPACK measurement tools.}

There is much research that attempted to utilize the TPACK framework to describe the complex relationship between technology, pedagogy, and content knowledge. The interrelationships of these forms of knowledge were studied to determine how best to prepare preservice teachers for the technology integration that is required by national standards (Banister \& Reinhart, 2012; Foulger, Buss, Wetzel, \& Lindsey, 2012; Sutton, 2011; Zeichner, 2012). Attempts to quantify the TPACK of individuals have been made, but there is concern about use of a measurement instrument to capture the complexities within this framework. Archambault and Barnett (2010) explained: "Specifically, before this model is offered as the proverbial panacea for redressing the challenges of teaching the 21 st century student, scholarship investigating the confusion between and among each of the domains described by the framework is needed" (p. 1657).

In addition, while measuring TPACK could aid in understanding why variances exist amongst the TPACK of graduate students, researchers expressed concern about whether such a measurement could provide the means to explain those variances. Other factors outside of the knowledge domains of TPACK (i.e. self-efficacy beliefs) may also contribute to the disparity of this knowledge, and consequent technology integration of preservice teachers. Differences in the knowledge that preservice teachers have about technology, pedagogy and content areas going into teacher education programs adds to the difficulty of being able to attribute TPACK advances solely to a teacher education program that promotes the framework.

\section{The Missing Contextual Element in TPACK Studies}

As the originators of the TPACK framework intended context to be considered when examining the technology integration beliefs and practices of graduate students, I reviewed the 
literature for studies concerning how the TPACK framework addresses such contexts (Koehler et al., 2013; Rosenberg \& Koehler, 2015). I was unable to locate any empirical studies that specifically examine the inclusion of CDL as a component of the TPACK framework. However, I did locate several conceptual studies that point to the need for research that examines how the inclusion of context can translate to more meaningful technology integration. In fact, Matthew Koehler, one of the originators of the TPACK Framework conducted a literature review to analyze TPACK research for the inclusion of context as he explained it was a pivotal component in understanding a teacher's technology integration practices (Rosenberg \& Koehler, 2015).

One conceptual framework that incorporated context in TPACK was developed by Porras-Hernandez and Salinas-Amescua (2013). In their framework, context was analyzed on three levels: micro, which is the classroom or learning environment; meso, which is the school or other setting where classrooms or learning environments exist; and macro, which are the "societal conditions that affect teaching, learning, and the development of both teachers and learners" (Porras-Hernandez \& Salinas-Amescua, 2013, p189). Their framework also considered both the students and the teachers as they "reciprocally affect teachers' TPACK (p. 189). Rosenberg and Koehler (2015) utilized this conceptual framework when coding the results of their literature review of TPACK research that considered context. According to their coding, they found that only $14 \%$ of the journal articles considered societal factors as a component of TPACK (Rosenberg \& Koehler, 2015). In his research, MacKinnon (2017) also addressed the framework of Porras-Hernandez and Salinas-Amescua (2013) when he analyzed three classroom contexts to point to both the importance and complexity of considering diverse educational settings when integrating technology. He concluded that technology integration could both positively and negatively be impacted by context. 
Another conceptual framework developed to prioritize the importance of context in the TPACK model was presented by Benton-Borghi $(2013,2016)$. Their framework incorporated universal design for learning (UDL). Benton-Borghi (2013) contended that due to the "increasingly diverse (racial, ethnic, and linguistic) and exceptional student population, and the inclusion of $80 \%$ of all students with disabilities in general education" (p. 246), the TPACK model requires a lens that addresses these complexities that are now prevalent in educational settings. This conceptual framework is another example of how researchers are seeking ways to ensure that the TPACK model considers the diverse settings that teachers face when determining how best to prepare teachers to integrate technology.

These previous studies and conceptual research led me to consider expanding the original understanding of context in the TPACK framework to include attention to the critical contexts of digital environments. The C-TPACK framework supports my contention that meaningful technology integration should include consideration of the sociocultural and political contexts and dominant discourses that are presented, represented, and developed in digital environments.

\section{Implications for Future Research}

As can be seen from the literature, the TPACK framework potentially provides teacher educators with an approach that aligns technology, pedagogy, and content area knowledge with the hope that an increase in technology integration in future classrooms will result. While the TPACK framework has provided a guide for educational researchers, there appears to be no consensus about how to decisively measure the knowledge domains within the framework, and their relation to one another. Various measurement tools have been utilized; however, the complexity of defining the relationships within TPACK created issues of reliability and validity 
within the methodology and data analysis of many studies. Researchers did appear to recognize this inherent complexity of knowledge relationships, and noted that it makes the measurement of TPACK equally complex. Interestingly, the researchers who tried to measure each component individually acknowledged the limitation this placed on gaining a complete picture of an individual's TPACK. The researchers who simplified the TPACK structure in order to create a more reliable measurement instrument made TPACK quantifiable, but did not garner a true understanding of the connected knowledge domains within the construct nor were they considering context. Once again, this points to a functionalist approach to teachers' technology integration practices. Consequently, it appears from review of the results of these studies, that utilizing a TPACK measurement tool that values the interrelationships of the knowledge domains and considers the context of the teaching and learning environments provides the more reliable picture. There is work to be done to ensure consideration of context and beliefs that impact teachers' technology integration practices.

From the start, the fluidity of the knowledge components that combine to form a TPACK framework has been complicated. Koehler and Mishra (2009) stated:

Technology knowledge (TK) is always in a state of flux - more so than the other two core knowledge domains in the TPACK framework (pedagogy and content). Thus, defining it is notoriously difficult. Any definition of technology knowledge is in danger of becoming outdated by the time this text has been published. That said, certain ways of thinking about and working with technology can apply to all technology tools and resources. (p. 64)

This statement supports the idea that technology knowledge and integration are less about knowing definitive skill sets in relation to specific types of technology, and more about the 
adoption of a mindset that is open to the fluid and dynamic nature of technology. Defining and measuring certain knowledge sets does not necessarily speak to the development of a mindset that allows for the continual integration of technology.

Also important to consider is that longitudinal studies that begin with TPACK measurement of graduate students and follow by examination of how TPACK is recruited into technology integration practices in future classrooms are very limited (such as in Graham, Borup, \& Hughes, 2009; Schmidt et al., 2009). As such, the study of the construct validity of such instruments was largely absent (Chai et al., 2010). This indicates a significant gap in the literature. If the study of the measurement of TPACK is not studied in conjunction with actual technology integration practices in classrooms, then it appears that predictive studies rather than subsequent (the latter of which could provide construct validity) would have to be relied upon to determine the value of a TPACK approach.

Two other gaps appeared to be present. First, there was little mention of direct observational data in the studies where TPACK was being measured. Surveys and self-reflection served as the primary means for data in the evaluation of graduate student TPACK. Second, there was limited consideration given to a critical digital lens when evaluating the TPACK of graduate students. The lack of attention to this socioculturally-based component of navigating, representing, making-meaning, and participating in a digital environment in these studies indicates a gap in the research. The developers of the TPACK framework structured it to explain and connect pedagogy, technology, and content "as they play out in classroom context" in teacher education programs (Koehler et al., 2013, p. 18; Davies \& West, 2014). Koehler et al. (2013) explained that utilizing a TPACK framework required recognizing that these "do not exist in a vacuum, but rather, are instantiated in specific learning and teaching contexts" (p. 16). In 
fact, Rosenberg and Koehler (2015) considered this an inherent problem with research conducted thus far that evaluates the TPACK model. These gaps in the literature led me to develop a framework that considered the missing critical component.

\section{Critical Digital Literacy Studies}

I was unable to locate research that specifically examined graduate students in teacher education courses and CDL. However, there were studies that addressed the critical uses of digital tools with graduate students, even though they did not claim a CDL framework. Using digital platforms in combination with a CDL framework can potentially give educators and students learning opportunities about how to become more socially aware and empowered by their personal beliefs and values. Specifically, online spaces can provide opportunities for students to see how they are positioned in their networked relationships and in society as a whole. When educators recruit a critical digital lens in their teaching practices, they challenge the hegemonic power of only a few and “...equip students with the mindset needed to help shape their culture." (Garcia, Seglem, \& Share, 2013, p. 113).

Gil de Zúñiga, Jung, and Valenzuela’s (2012) study showed that utilizing digital resources resulted in a noted increase in participation in politics, discussion, and civic engagement which shows the impact that SNS tools have to promote democracy (Gil de Zúñiga, Jung, \& Valenzuela's, 2012). Gil de Zúñiga et al. (2012) concluded that ...learning about what happens around us and in our community, reflecting on it, and discussing about it with others constructively affects the political realm; as well as it facilitates a cohesive community by enabling citizens to engage in civic action. (p. 329) They proposed that the information sharing that occurs in digital environments could lead to greater representation of an individual's voice (Gil de Zúñiga et al., 2012). 
Similarly, Chen (2013) showed that “...resource-rich bonding helps overcome the digital divides in access, general use, and online communication" (p. 13). The development of social ties via digital spaces can provide individuals with access to resources, people, and information (Chen, 2013). He explained the importance of a diversity of connections to help strengthen an individual's online presence and representation. This aids in developing "cognitive flexibility," a skill that he asserts promotes an individual's learning and can aid in bridging digital divides (Chen, 2013, p. 16).

Dabbagh and Kitsantas (2012) also recognized the value of social media use in planned learning environments (PLEs). Their study focused on the ways that students represent themselves within PLEs. They believed students needed to be educated about how their online choices and decisions contributes to the development of an online identity (Dabbagh \& Kitsantas, 2012). The use of social media in a PLE format could pose significant problems for students in middle and high school grades who may not have been exposed to critical digital practices. When educators engage in CDL practices, they aid students in learning how to effectively navigate these platforms and benefit from the rewards of learning opportunities and resources.

Hughes' (2009) study identified what higher education institutions could do to move towards total engagement of students who operate in a Web 2.0 world. While his study examined college students, his findings appear applicable to students of all levels. He directly focused on student point of view and explained that this means "ensuring they possess the skills and understanding to search, authenticate and critically evaluate material from the range of appropriate sources, and attribute it as necessary" (Hughes, 2009, p. 7). Notably, this is also a 
focus of CDL. Hughes offered an important insight about students entering college and the environment they face regarding technology use in classrooms::

Characterised broadly, it is hierarchical, substantially introvert, guarded, careful, precise and measured. The two worlds are currently co-existing, with present-day students effectively occupying a position on the cusp of change. They aren't demanding different approaches; rather they are making such adaptations as are necessary for the time it takes to gain their qualifications. (Hughes, 2009, p. 9)

According to Hughes (2009), students would eventually stop trying to adapt to this antiquated approach to learning and start choosing alternatives. He added that employers aren't seeking students who approach information in traditional ways. Specifically, he stated that employers are demanding “....a range of 'soft skills' such as networking, teamwork, collaboration and self-direction, which are among those fostered by students' engagement with Social Web technologies" (Hughes, 2009, p. 9). In fact, corporations have also called on educators to develop 21st Century Workplace Skills which reflect prioritizing the development of students' CDL and digital literacy (van Laar, van Deursen, van Dijk, \& de Haan, 2017). Hughes' (2009) view was shared by Dabbagh and Kitsantas (2012) who were critical of higher education that relies on "traditional platforms" (p. 7) that do not allow for students to use new text formats to individualize their learning and social presence. This highlights a disconnect between what higher education is offering and what students actually want and need to stay engaged and have success outside of school.

Similar to Dabbagh and Kitsantas (2012) and Hughes (2009), McGloughlin and Lee (2010) studied college student use of digital platforms. They specifically addressed the role that SNS plays in personal learning environments (PLEs). They contended the format of social media 
lends itself well to self-regulated learning where students are active participants in shaping their knowledge base (McGloughlin \& Lee, 2010). While their study promoted the benefit of PLEs for increasing student autonomy, Mcloughlin and Lee (2010) also explained the importance of preparing students with critical analysis skills before they engaged with them. No suggestion as to how this preparation should take place is offered. Also, while critical reflection and analysis are limitedly present in those studies, components of CDL are not, showing another gap in the literature about higher education teacher programs.

All of the studies above supported the potential of digital environment use in educational settings. Researchers prioritized the critical analysis of the information and resources of digital spaces which could support a CDL framework. Participation in those spaces can lead to a student's development of social awareness (Chen, 2013; Moran et al., 2011; Gil de Zúñiga et al., 2012; Riedl, Köbler, Goswami, \& Kremar, 2013) and can result in collaboration and successful networking skills development which has been shown to have a positive impact on learning (Chen, 2013; Gil de Zúñiga et al., 2012; Lim \& Richardson, 2016; Riedl et al., 2013). However, students are not all savvy in how best to navigate those environments for these purposes. Kirschner (2015) studied students' use of the SNS Facebook. He determined that regardless of how often or how familiar students are with social online platforms, transitioning from personal to educational use requires guidance from educators (Kirschner, 2015).

In his qualitative study, Gainer (2010) examined the practices of academically and ethnically diverse middle school students participating in an after school critical media literacy project. He found that the students actively engaged in high level thinking and analysis about representation of youth in media. Gainer (2010) explained that the students "drew on their cultural resources and life experiences as they deconstructed, debated, resisted, and reimagined 
dominant narratives of urban students" (p. 372). He emphasized the importance of the teacher's role in facilitating such practices. This requires an understanding of youth culture and engagements with the digital environments they continually operate in (Gainer, 2010).

Choudhury and Share (2012) studied low-income, middle school ESL students to determine if they were able to utilize SNS to empower themselves. They analyzed data to determine if students understood the social construction of messages. Conclusions that were found included that with strong teacher guidance, participation resulted in increased self-esteem, pride in their community, and deeper levels of critical thinking (Choudhury \& Share, 2012).

All of these studies pointed to the importance of a teacher's knowledge and application of CDL practices to ensure that students are able to critically analyze and reflect on the resources and the representations of knowledge and information that exist in digital environments. Importantly, this prioritizes the development of both pre-service and practicing teachers' CDL practices. The review of this research shed light on the ways that engaging in CDL practices can promote a diversity of voices, develop individual representation, and challenge dominant discourse within content in online platforms.

\section{Technology Integration in Classroom Practices}

As explained earlier, I searched for and found a limited number of studies specifically naming a CDL framework for the technology integration practices of graduate students and practicing teachers. Consequently, I expanded my review to include studies of pre-service and practicing teachers that were recruiting components that are considered foundational to CDL practices. Those components included the ability to develop knowledge and represent oneself; understand, navigate, and create within the social structure of the digital environment; and 
recognize the positions of power at work in that environment and how that power structure impacts each individual. As with earlier searches, this resulted in a limited number of studies.

Reidel and Draper (2011) addressed the professional development of preservice middle school teachers in research context in critical literacy practices as they prepared to teach Social Studies in the hope that it would lead to meaningful technology integration. The pre-service teachers engaged in critical literacy practices each week during their Social Studies methods course where the focus was on the practice of making "text to self, text to text, and text to world connections" with the provided readings. Discussions ensued after each week's activity to evaluate how critical literacy practices could be incorporated into the classroom. Reidel and Draper (2011) concluded that mentoring graduate students in critical literacy practices with regards to digital media is essential. The study stopped short of studying graduate students as they implement what they learned which points to a gap in the literature.

In their study of practicing teachers, Gorder (2008) surveyed teachers about their use of technology in their classrooms. Phase 3 of their study addressed the how teachers provided context, problem solving, and critical analysis of information during technology integration practices. Important to note that while these practices represent critical analysis skills, they do not address social, cultural, and political contexts and dominant discourses and power structures which are considered foundational to CDL (Avila \& Pandya, 2013; Song, 2016; Watulak \& Kinzer, 2013). Gorder (2008) found that the teachers surveyed felt they struggled to meaningfully integrate technology and that they focused on more substitutive uses which do not necessarily include CDL practices. The teachers cited lack of experience and exposure to technology for that purpose as their reasons for this. 
Similarly, Ertmer (2005) found that a majority of teachers do not have a strong understanding of how technology can translate to learning. She determined that teachers with constructivist beliefs about teaching and learning are the most likely to integrate technology. Constructivism promotes learning and construction of knowledge from personal experiences (Bhattacharjee, 2015; Dewey, 1938; Terwel, 1999). These personal experiences are shaped by contexts such as diversity, and social settings (Terwel, 1999; Vygotsky, 1978). As such, constructivist teaching practices may provide opportunities for CDL practices, even if they do not end up reflecting CDL. This study both contributed to my understanding about graduate students, CDL, and technology integration practices, and directed me to other studies that considered recruiting constructivist beliefs to technology integration practices.

Like Ertmer (2005), Chen (2008) found that teachers whose beliefs aligned with constructivism were most likely to incorporate the use of critical reflection and analysis of information. He explained that teachers self-indicating they had constructivist beliefs intended to use technology integration during lessons to challenge students to seek multiple perspectives about content leading to critical discussions (Chen, 2008). However, his findings showed that those teachers' beliefs and intentions did not lead to meaningful, critical technology integration practices in actuality. Chen (2008) explained that additional information and concerns caused this disconnect. He specifically identified information about students, teachers' instructional purposes, characteristics of the curriculum, and constraints of instructional situations as causes. This could also speak to the dominant discourses that are represented in the materials, standards, and curriculum of schools that poses a barrier for recruiting CDL practices to classroom instruction. 
Anderson and Maninger (2007) surveyed graduate students about their perceived abilities, beliefs and intentions to integrate technology in their future classrooms before and after taking an educational technology course at a large U.S. university. Among topics covered in the course were constructivism and critical analysis as they related to technology integration practices. At the conclusion of the course, a majority of the graduate students indicated they intended to integrate technology in their future classrooms. This study did not specifically address the roles the graduate students see constructivism and critical analysis playing in those future practices. In addition, it was unclear from the study if components of CDL were actually included in how the researchers understood critical analysis.

\section{Discussion and implications of the CDL studies.}

Song (2016) explained that "The critical in critical digital literacies refers to the insistence in critical theory on intensive examinations of dominant narratives and the establishment of counter-hegemonies" (p.17) in digital environments. While the studies reviewed here showed that those researchers who incorporated CDL in their studies seemed to support this understanding, few of those studies followed how graduate students recruited CDL into classroom practices. This is a gap in the research. Future research in this area may do well to consider specifically designed teacher education coursework and professional development that addresses the key components of CDL practices. Repeatedly, students expressed a lack of modeling and purposeful experiences with CDL practices that could lead to increased learning outcomes as an issue with the current use of online platforms (Bruneel, De Wit, Verhoeven, \& Elen, 2013; Mao, 2014; Roblyer, McDaniel, Webb, Herman, \& Witty, 2010; Selwyn, 2009).

It is also clear from that research that empowering students through the employment of a critical digital lens could provide them with the opportunity to be active participants in shaping 
not only their own identity, but also potentially exposing hegemonic practices which could lead to a more democratic society. The studies reviewed here showed that individuals could reap the benefits of access, resources, knowledge and collaboration through social media use. At the same time, boyd (2007) explained that the affordances that SNS gave teenagers were complicated in nature. She warned that navigating through the social connections made can prove difficult. boyd (2007) explained:

Teens are struggling to make sense of who they are and how they fit into society in an environment in which contexts are networked and collapsed, audiences are invisible, and anything they say or do can easily be taken out of context. (p. 53)

A CDL framework is a way that educators can help guide students in active participation and purposeful development of online critical literacy practices that can empower them. Utilizing such a framework can help teenagers with the struggles that boyd (2007) identified. Employing a CDL lens could aid educators and students in developing ways to democratically and effectively use social media for learning and empowering opportunities. Developing CDL skills can also help middle and high school students prepare for the ways in which social media platforms are being used in colleges today.

\section{Conclusion}

Overall, this examination of research revealed the need to consider the direction and structuring of teacher education programs when determining both how to teach and develop a mindset about technology integration in preservice and practicing teachers that will successfully be recruited to their future teaching practices. I have identified the following gaps in the literature from which I have developed my research questions. First, the literature surrounding critical media/digital literacy did not strongly focus on the development of CDL in graduate 
student education coursework. Second, there was little research that addressed the critical media/digital literacy of middle and high school students. Third, the research was largely predictive in nature. Fourth, there was a noted absence of consideration of context when measuring graduate student TPACK. Watulak and Kinzer (2013) explained that the "notion of context is incorporated into the TPACK model, but its role is not explicitly addressed" (p143) and neither has that context been expanded to include consideration of the sociocultural and political contexts and dominant discourses at work in digital environments. Fifth and finally, the findings relied strongly on surveys and self-reflection rather than observation of actual teaching practices. Using the C-TPACK framework and taking direction from these findings in this literature review, I structured my research questions and designed this study to examine the gaps that I found and to guide my analysis for this study. 


\section{CHAPTER III: METHODOLOGY}

The purpose of this study was twofold. First, the objective was to gain an understanding of how practicing teachers believe they are prepared to meaningfully and critically integrate technology into their classroom practices. Second, the intent was to understand how practicing teachers recruited those beliefs and preparations into their planning and instruction practices. This included gaining an understanding of what they believed led to their decisions surrounding technology integration and critical digital literacy (CDL) practices and any barriers they may have faced when teaching their lessons.

To achieve these objectives, I developed the following research questions for this study:

RQ1: What is the critical, technological, pedagogical and content area knowledge of graduate students in one university's School of Teaching and Learning?

RQ2: How does a subset of these graduate students, who are also practicing teachers, recruit their C-TPACK into their planning and instruction (i.e. their practices)?

RQ3: What does this same subset of graduate students/practicing teachers identify as the contributing factors that supported or hindered their abilities to engage the critical dimensions in their teaching?

From this point forward, these questions will be referred to as: Research Question 1 (RQ1), Research Question 2 (RQ2), and Research Question 3 (RQ3). This was a mixed-methods study which consisted of two phases.

Once IRB approval was obtained, I emailed all enrolled graduate students in the School of Teaching and Learning at a large, public university in the Midwest region of the United States asking them to consider participating in my study. (From this point further, this university will be 
referred to as Middle State University or MSU). In Phase 1, consenting students completed a likert-scale survey which also contained open-ended questions. Descriptive statistics were calculated for the likert-scale answers and the open-ended questions were coded. The results served as data for RQ1 as well as a guide to determine which participants I would ask to participate in Phase 2 of the study.

Because my study focused on practicing teachers, I used the survey to ask students to indicate whether they are practicing teachers. Only those indicating who were practicing teachers were recruited for further participation. In Phase 2, I requested and received the practicing teachers' lesson plans that they indicated included technology integration prior to observing them; I conducted observations of those lessons, and then I interviewed the teachers after I completed my observations. I used First and Second Cycle Coding (Miles, Huberman, \& Saldana, 2014; Saldana, 2016) for analyzing the open-ended survey questions, the lesson plans, observations, and interviews. Below I detail specifics concerning the processes for both the quantitative and qualitative methods that I used in the analyses.

\section{Methodology}

This mixed-methods study employed both quantitative and qualitative methods of data collection to answer my research questions. Creswell (2014) explained that each method of data collection can provide different types of information, and each type has limitations and strengths. He states that a mixed-methods study integrates the data by "merging...connecting...or embedding" (Creswell, 2014, p. 217) the findings within the analysis. A benefit of mixing methods is that the different forms of data collected can be triangulated, potentially resulting in a more thorough understanding of the research problem (Creswell, 2014; Creswell \& Plano Clark, 
2011; Smyth, 2006). The benefit of these multiple data sources is that they offer different kinds of data to answer research questions in different ways.

My analytical approach was both deductive and inductive. It was deductive in that I began with analyzing the TPACK framework and studies whose aim was to quantitatively predict which teachers would most likely integrate technology based on the quantitative measurement of seven domains of knowledge. As explained earlier, those studies were largely predictive and did not include or address the critical digital literacies of the participants. I still found value in the TPACK surveys as I believe they provided a "snapshot" of a teacher's beliefs about his/her knowledge in regards to technology. However, my theoretical beliefs are grounded in the C-TPACK framework, which prioritizes the consideration of the social, historical, and contextual impacts of operating in digital environments. Critical theory has a necessary and valuable place in the development of teacher and student digital literacies as it can help ensure that critical analysis of what is created and represented in digital environments can lead to digital literacies that represent diverse voices. That led me to develop a CDL section as an addition to existing TPACK surveys. I called this C-TPACK, with the "C" representing the critical component of the survey. In this way, the earlier TPACK studies provided a premise for the development of my survey specifically, and my study in general, and as such could be considered a deductive approach. At the same time, I considered the C-TPACK survey to be just one piece of the whole, and at no time do I claim the survey results to be generalizable.

The information gained from the C-TPACK surveys of the participants served two deductive purposes. First, it allowed me to focus on participants who believed they have moderate to high levels of C-TPACK. By adding the CDL section, I hoped to find students who also were more likely to recruit C-TPACK in their practices. Second, it provided information I 
used for comparative purposes with my qualitative data. At the same time, I employed a social constructivist approach to this research as I believed that it was necessary to include qualitative components to gain a deeper understanding of how/whether their C-TPACK knowledge was recruited to teaching practices. This led me to approach this study inductively as well.

An inductive approach with theory can result in an emerging qualitative theory or pattern when mixed-methods are employed (Creswell, 2014). I began the study with my theoretical ideas described in Chapter 2. Those ideas led me to develop a theoretical framework I call the CTPACK framework. That framework prompted me to apply social constructivist and constructivist grounded theory when considering all aspects of my methodology and data analysis. Charmaz (2014) explained that a constructivist approach means not only that "researchers must examine rather than erase how their privileges and preconceptions may shape the analysis, but also that their values shape the very facts that they can identify" (p. 13). This use of deductive and inductive approaches to the data and analysis provided a means for postpositivist and constructivist paradigms to work symbiotically.

Below, I explain my ontological and epistemological beliefs and how they led me to incorporate methods that fall within postpositivist and constructivist paradigms. From there, I highlight social constructivism and constructivist grounded theory and how those theories informed me throughout data collection decisions, data analysis, and data interpretations.

\section{Ontological and Epistemological Beliefs}

Glesne (2016) explained that ontology is your belief regarding the nature of reality or how you see and believe the world is shaped. She stated, "What you believe about the nature of reality, in turn, affects the kinds of questions you ask of it, what you consider knowledge to be" (Glesne, 2016, p. 5). In conjunction with ontological beliefs, epistemological beliefs should be 
considered when determining methodology. Kivunja and Kuyini (2017) explained that epistemological beliefs include reflecting about how we know what we know, and whether evidence is truth (Kivunja and Kuyini, 2017).

My ontological and epistemological beliefs support the idea that reality is shaped by perspectives, experiences, and interpretations. As such, reality is not limited to what can or can't be measured, and can be subjective. When reflecting about those beliefs, Kivunja and Kuyini (2017) encouraged researchers to ask: Is knowledge something which can be acquired on the one hand, or, is it something which has to be personally experienced? This question was at the heart of my study. My use of postpositivist and constructivist paradigms in combination allowed me to delve into that question by juxtaposing data from the quantitative survey with qualitative data produced from open-ended questions, observations, and interviews. Quantitative information provided supplementary data that combined with qualitative data to provide deeper understanding of what was happening at a particular time and in a particular space. This can further lead to development of theories and provide direction for future studies (Charmaz, 2014; Smyth, 2006). Charmaz (2014) explained that utilizing mixed-methods is consistent with a grounded theory approach and can lead to benefits "when grounded theorists can follow up with qualitative research on intriguing but undeveloped quantitative responses" (p. 324).

I inductively moved from the quantitative data to the qualitative data to gain a stronger understanding of how different forms of knowledge (C-TPACK), teachers' practices, and teachers' perspectives worked together to provide insight and direction about the technology integration and CDL practices of teachers. My choice of data collection methods privileged the teachers' opinions, experiences, and perspectives, which provided valuable information about their realities. I also recognized that my positionality made my methodological choices and 
findings constructions that were influenced by my own subjectivities. Overall, my methodological approach was consistent with my ontological and epistemological beliefs and provided detailed information leading to insights that furthered the development and honing of my C-TPACK framework.

\section{Paradigms.}

My ontological and epistemological beliefs led me to two research paradigms: postpositivist and constructivist. Kivunja and Kuyini (2017) explained that a research paradigm is "the conceptual lens through which the researcher examines the methodological aspects of their research project to determine the research methods that will be used and how the data will be analysed" (p. 26). A researcher's paradigm reflects his/her beliefs and practices which influence the development of the research questions as well the methods they choose for studying them (Kivunja and Kuyini, 2017; Morgan, 2007; Smyth, 2006). Knowing a researcher's paradigm provides an understanding of how meaning has been constructed from the data (Kivunja and Kuyini, 2017).

According to Savin-Baden and Major (2013), postpositivists believe that "reality exists and may be discovered (although imperfectly known) through logical processes" (p. 20). Creswell (2014) stated that postpositivists hold a "deterministic philosophy" (p. 7) where the researcher focuses on cause and effect relationships. Greene (2010) explained this causality as "complex, multiplistic, and interactive" (p. 65). An objective reality exists in this paradigm, and the quantitative measuring of collected data leads the researcher to possible cause(s), which can lead to predictions based not on truth but rather on probability (Creswell, 2014; Greene, 2010). On the other hand, constructivists believe that "meanings are constructed" (Savin-Baden \& Major, 2013, p. 23) and that "truth is a result of perspective and therefore knowledge and truth 
are created rather than discovered (p. 23). Generalizability and probability are not the goals of a constructivist. Rather, knowledge is deemed contextual, based on an individual's experiences and perspectives, and as such is interpreted and constructed (Greene, 2010).

Both paradigms guided my methodological choices in several ways. Researchers have much to say about using multiple paradigms. Johnson (2011) provided his view that mixed research tends to rely on the following: (a) ontological pluralism and ontological complexity; (b) the purposeful use of multiple epistemologies that allow the construction of a complex emergent epistemology (sometimes on a project-by-project basis); and (c) an emphasis on the importance of both qualitative and quantitative methods. (p. 34) Saldana (2016) explained that quantitative and qualitative data used together can provide a heuristic for analysis. The postpositivist paradigm allowed me to advance previous research in the TPACK area. However, such research showed that the TPACK framework lacked a critical lens and TPACK surveys have largely been predictive in nature (Chai et al., 2010; Koh \& Divaharan, 2011; Pamuk, 2012; Paratore et. al, 2016). Examining the predictive component and adding a CDL component to this survey was of interest to me, and postpositivism supported the use of this quantitative method; at the same time, it was equally important for me to understand how teachers' C-TPACK may or may not be recruited into classroom practices. To accomplish this, I decided to first determine the participants' C-TPACK as a starting point which provided an opportunity to identify potential predictive connections between survey answers and classroom practices.

While the quantitative component provided me with valuable information for choosing my subset of participants and provided a "snapshot" of their C-TPACK at a given point in time (see the Participants section below), I believed that it alone could not lead me to a stronger 
understanding of how teachers actually recruit their C-TPACK into their planning and instruction (i.e. their practices) and what they identify as the contributing factors that supported or hindered their abilities to engage the critical dimensions in their teaching. Charmaz (2014) stated that "an emerging grounded theory can indicate needing more than one type of data and can incorporate more than one type of analysis" (p. 323). This postpositivist approach in combination with a constructivist approach allowed me to gain a stronger understanding of how the C-TPACK survey results could work together with the qualitative data to generate richer data. My understanding of how the approaches worked together was informed by Charmaz $(2010,2014)$. Charmaz (2010) stated that researchers "can only claim to have interpreted $a$ (author's emphasis) reality, as we understood both our own experience and our subject's portrayals of theirs" ( $p$. 196). Inclusion of the quantitative component of the survey provided me with a snapshot of the participants' beliefs about their own C-TPACK. By further applying constructivist grounded theory, researchers are sensitized to "multiple realities and multiple viewpoints within them; it does not represent a quest to capture a single reality" (Charmaz, 2010, p. 197). As such, use of constructivist grounded theory can "provide a path for researchers who want to continue to develop qualitative traditions without adopting the positivistic trappings of objectivism and universality" (Charmaz, 2010, p. 196).

The constructivist paradigm led me to include open-ended questions, lesson plans, observations, and interviews. Use of a constructivist paradigm aligned with my ontological belief that reality is shaped by perspectives, experiences, and interpretations. The C-TPACK likert scale questions provided some indication of the participants' view of their knowledge concerning technology integration and CDL practices, but that form of data collection stopped short of providing the teachers with opportunities to explain their perspectives and expand upon their 
processes. Using a constructivist paradigm allowed me to gather data about their approaches through both their created documents (lesson plans) and their classroom practices which I observed. This paradigm also afforded me the opportunity to hear and to privilege the teachers' perspectives through open-ended questions on the surveys and interviews. With this

understanding, I approached the methodology of this study from both a social constructivist and a constructivist grounded theory perspective.

\section{Social Constructivism}

Social constructivism assumes that "human beings construct meanings as they engage with the world they are interpreting" (Creswell, 2014, p. 9). Research using this lens centers on understanding the dialogue and negotiations of contexts that individuals engage in and with to develop knowledge and meaning (Savin-Baden \& Howell Major, 2013). Analysis of the specific contexts and experiences that shape the actions of individuals is prioritized when such a lens is utilized (Creswell, 2014). This supports providing opportunities for participants to "express their views of the situation being studied" (Creswell, 2014, p. 8). The use of open-ended questions about technology integration and critical digital literacy, the inclusion of the teachers' lesson plans, and semi-structured interviews with the teachers provided opportunities for the inclusion of participants' viewpoints through both written and verbal dialogue about technology integration practices and application of CDL.

In addition, the inclusion and analysis of observations align with social constructivism. Vygotsky (1978) emphasized the important roles that cultural and social mediation play in learning. He explained that because of the complexity of the process of learning, specific consideration of these contexts where individuals operate is necessary if we are to understand how they come to acquire knowledge and make meaning (Vygotsky, 1978). Handsfield (2016) 
explained that in social constructivism, "development is mediated by culturally produced tools and signs" (p. 57) and it is this mediation that leads to internalization of the knowledge learned. Studies that utilize a social constructivist approach privilege this constructed meaning that individuals make and explain that it can be more clearly understood through studying the interactions and activities of participants in certain contexts (Creswell, 2014). The use of observations allowed me to witness teachers' practices and record my view of the ways teachers and students responded to the decisions made by the teachers concerning technology integration. The observations also provided me with direction in the development of the interview questions. The interviews allowed me to develop a stronger understanding of what happened in the classroom and compare what my perceptions were with the teachers' perspectives and experience. That information worked together to help me interpret and construct meaning from the data.

The C-TPACK surveys provided an opportunity for the teachers to self-reflect about their own C-TPACK. Aligning with the social constructivist approach, I utilized the open-ended survey questions to learn about contexts within which the graduate students had opportunities to experience and practice both technology integration and critical digital literacy. These questions were directed at their experiences in their teacher education programs, the student teaching environment, and graduate coursework in education. While this survey provided an opportunity for teachers to express their beliefs and experiences, observations provided a means for me to examine and compare what their beliefs were with how they recruited those beliefs and knowledge into classroom practices. 


\section{Constructivist Grounded Theory}

Social constructivism is related to constructivist grounded theory in that both prioritize interactions and context when understanding how individuals make-meaning and engage in social practices. While social constructivist theory centers on the study of the cultural and social contexts as they mediate the learning and actions of the participants, constructivist grounded theory centers on allowing researchers to "construct their respective products from the fabric of the interactions, both witnessed and lived" (Charmaz, 2014, p. 178). Savin-Baden and HowellMajor (2013) explained that when researchers apply this theory, "the researcher and the researched are co-producers of data, and that it is important for researchers to immerse themselves in the data in order to embed the participant data in both the findings and the final research outcome" (p. 185). When employing constructivist grounded theory, the researcher's findings do not "transcend experience but re-envision it" (Charmaz \& Mitchell, 1996, p. 299) where the researcher's "reflecting, witnessing, wondering, and accepting" (p. 299) work together to present the participants' lived experiences.

This theory undergirded my study as I utilized C-TPACK surveys, open-ended questions, lesson plans, and semi-structured interviews to provide opportunities for both myself and the teachers to produce data. I was a co-producer of data through my observations of teaching practices, my coding of participant data, and my final analysis of that data. Charmaz (1995) explained that this theory positions the researcher to provide "a description of the situation, the interaction, the person's affect and perception" of the data collection (p. 33). My treatment of all data reflected the goal of constructivist grounded theory where the personal experiences of the participants are prioritized and are reflected in final analysis (Charmaz, 2001). 
What I learned from the quantitative measurements from the survey combined with the qualitative findings from open-ended questions, lesson plan analysis, and teacher observations and interviews and led to my findings. Insights I gained served as a "grounding" for further development and honing of the C-TPACK framework. In this way, constructivist grounded theory was a dialectic between my theoretical ideas entering this study and what I learned from the study. In addition, I operationalized a dialectic between postpositivist and constructivist paradigms.

\section{Research Design}

This mixed-methods study spanned one academic semester and included two phases of data collection. Phase 1 consisted of pre-observation on-line surveys of enrolled graduate students in the School of Teaching and Learning (TCH) at MSU. The online survey contains demographic questions, C-TPACK likert-scale questions, and open-ended questions regarding technology integration experiences and CDL knowledge. It was administered to MSU, TCH graduate students at the beginning of the spring 2018 semester. The quantitative portion of the study consisted of analysis of the C-TPACK likert scale items from which descriptive statistics were generated. Analysis of the survey data helped me determine which teachers to recruit for the sub-set of participants for Phase 2 of the study.

Phase 2 of this study was qualitative. After identifying and receiving consent from graduate students identified as practicing teachers, and whose survey answers indicated a moderate to high level of C-TPACK, I collected and analyzed lesson plans that the teachers indicated included technology integration. After lesson plan analysis, I conducted observations and follow-up interviews. The qualitative components of this study included the use and analysis 
of open-ended survey questions, lesson plan analysis, observations of teachers, and interviews of teachers. All of the components of each phase are detailed in the procedures section below.

Below, I present a description of the participants and setting. Following this, I provide the data collection procedures for Phase 1 and 2 . Then, I move on to my explain and present my data analysis procedures.

\section{Participants and Setting}

To identify participants for this study, I used purposeful sampling of graduate students in the School of Teaching and Learning at MSU, a large public university in the midwestern region of the United States. At the time of my study, the graduate student demographics in the College of Education for this university included the following: 2,370 students; $65.18 \%$ of the graduate student population was female; and $73.5 \%$ of those students identified as white (Middle State University, 2018). Demographic information more specific to the graduate students in the School of Teaching and Learning at MSU was obtained from the survey completed during Phase 1 and is included in Chapter 3. It included gender, age, race/ethnicity, primary language spoken, level of education completed, family household income, and major at the university. This provided descriptive information about the participants' personal characteristics and backgrounds that is included in the findings.

Purposeful sampling is the selection of individuals for inclusion in a study based on who is most likely to provide information that directly speaks to the research questions (Creswell, 2014). After receiving IRB approval for my study, I reached out to the Director of Graduate Studies in the School of Teaching and Learning at MSU, who identified graduate courses in the department and the professors teaching those courses for the spring 2018 semester. My survey was distributed two different times to the ListServe containing emails of all of the identified 
enrolled graduate students to help increase the participation level. In addition, I emailed all of the professors individually and asked them to consider placing my survey with recruitment email on their Learning Management Systems for their courses. In total, 58 graduate students consented and completed my survey and served as my Phase 1 participants.

The graduate students who completed all parts of the survey and whose C-TPACK and open-ended questions showed they had the highest self-indicated levels of C-TPACK and CDL knowledge were identified as potential participants for Phase 2 of this study. In addition, to be further recruited in my study, I required that participants be practicing teachers, as I needed to be able to analyze their lesson plans and observe them teaching those plans. On the survey, participants were asked to indicate if they were practicing 6-8 grade teachers or 9-12 grade teachers. Of the 58 participants who completed surveys, 25 were practicing teachers. All 25 teachers consented to be contacted about further participation in this study (Phase 2) and all provided their names and email addresses.

To determine who of the 25 teachers to invite to participate in Phase 2, I first individually compared the likert scale survey answers to identify the teachers who self-indicated they had a high level C-TPACK. Specifically, answers to questions 18-25 were analyzed. See Appendix D for those survey questions. The teachers who indicated they agreed or strongly agreed in $90 \%$ of those answers were identified as potential Phase 2 participants. This resulted in 16 potential Phase 2 participants.

All 16 teachers were then recruited via an email that contained both an explanation of what would be asked of them as well as a link to a consent form. See Appendix C for email. The consent form contained five questions asking the following: Do you give your consent to 
participate in Phase 2 of this study; what is your name; what is the name of your school; where is your school located; and what is the name of the class I will be observing.

Of the 16 teachers recruited, six consented to participate in Phase 2; however only four were chosen. Two were eliminated from consideration as one had a student teacher she was mentoring and consequently was not, herself, teaching. The other teacher was going on maternity leave and had a substitute teacher during the time I needed to observe. Consequently, those two teachers did not fit the criteria for Phase 2 participation. See Table 3.1 below for demographic information about the four teachers who comprised the subset. The research activities that the sub-set of participants participated in included: provision of their lesson plans before they taught; observation of them as they implemented those lesson plans; and a post-observation interview. Table 3.1

Demographics of Phase 2 Participants

\begin{tabular}{|c|c|c|c|c|c|}
\hline Participant & Gender & Age & Content Area & $\begin{array}{l}\text { Highest } \\
\text { Degree }\end{array}$ & $\begin{array}{c}\text { Grade Level } \\
\text { Taught }\end{array}$ \\
\hline Diane & Female & 36 & Science & Doctorate & $\begin{array}{l}\text { Middle } \\
\text { School }\end{array}$ \\
\hline Kate & Female & 24 & Reading and Language Arts & $\begin{array}{c}\text { Bachelor's } \\
\text { Degree }\end{array}$ & $\begin{array}{l}\text { Middle } \\
\text { School }\end{array}$ \\
\hline Andrew & Male & 56 & $\begin{array}{c}\text { Social Science, Communications, } \\
\text { Digital Media, English }\end{array}$ & $\begin{array}{l}\text { Master's } \\
\text { Degree }\end{array}$ & High School \\
\hline Sara & Female & 46 & Spanish & $\begin{array}{l}\text { Master's } \\
\text { Degree }\end{array}$ & High School \\
\hline
\end{tabular}

\section{Data Collection Procedures}

The collection and analysis of data generated from the surveys, open-ended questions, lesson plans, observations, and interviews allowed for triangulation of data which can increase the validity of the study findings (Creswell, 2014; Weyers, Strydom, \& Huisamen, 2014). Below, I explain my data collection procedures for each phase. 


\section{Phase 1}

During Phase 1, I administered the online C-TPACK survey to all consenting graduate school students in the School of Teaching and Learning at MSU via a link to Qualtrics, a survey delivery platform. I then analyzed the likert-scale answers using descriptive statistics to determine which graduate students self-indicated a moderate to high level of C-TPACK. In addition, I analyzed the open-ended question answers using In Vivo coding to identify those graduate students who believed they had technology integration experiences as well as a moderate to strong knowledge and understanding of critical digital literacy. From that pool of participants, I identified those graduate students who indicated that they are practicing teachers.

The survey analysis was important as it directly spoke to my research questions: (RQ1)

What is the critical, technological, pedagogical and content area knowledge of graduate students in this university's School of Teaching and Learning? and (RQ2) How does a subset of these graduate students who are also practicing teachers recruit their C-TPACK into their planning and instruction? The information gained provided me with an understanding of how graduate students believed they were prepared to meaningfully and critically integrate technology into their classroom practices as well as how they believed they currently integrate.

\section{Survey.}

The survey contained C-TPACK likert scale items, technology integration open-ended questions and CDL open-ended questions which were analyzed to determine those graduate students who self-indicated the highest levels of C-TPACK and CDL. Those who indicated they are practicing teachers, in addition to those with the highest self-indicated levels of C-TPACK, were contacted about further participation as the sub-set for Phase 2 of this study (see explanation above provided in Participants and Setting). To determine those recruited further, I 
used descriptive statistics to analyze the likert-scale answers and to analyze the open-ended technology integration and CDL questions (See Data Analysis section below for details about this coding).

\section{C-TPACK questions.}

A portion of the C-TPACK likert scale and open-ended technology integration questions utilized for this study came from a previously validated self-assessment TPACK survey developed by Schmidt et al. (2009). There are seven knowledge domains, which represent seven subscales of this survey. Each subscale contains likert-scale questions totaling 47 in all. The knowledge domains include: Technology Knowledge (TK), Content Knowledge (CK), Pedagogical Knowledge (PK), Pedagogical Content Knowledge (PCK), Technological Content Knowledge (TCK), Technological Pedagogical Knowledge (TPK), and Technological Pedagogical Content Knowledge (TPCK). Schmidt et al. (2009) determined that the internal consistency reliability for each knowledge domain ranged from .75 to .92 which indicates that each domain's reliability is considered acceptable to excellent (Schmidt et al., 2009).

In addition, I created another domain of questions for this survey called "Digital and Critical Digital Literacies." This was necessary to support my research questions as the critical dimensions of teachers' technology use in their practices are examined. To develop the questions for this domain, I relied on the definition provided earlier for CDL of which there were several components. This includes the understanding that CDL extends beyond the development of a specific set of technological tools. CDL reflects the ability to develop knowledge and represent oneself; understand, navigate, and create within the social structure of the digital environment; and recognize the positions of power at work in that environment and how that power structure impacts each individual. Watulak and Kinzer (2013) define CDL as encompassing four main 
elements: "understanding cultural, social, and historical contexts of technology use; critical thinking and analysis; reflective practice; and facility with the functional skills and tools of digital technology production (p. 128). Both the CDL definition and those four components served as a guide for the domain questions.

My survey was specifically designed to examine graduate students' self-indicated CTPACK at a particular moment in time. While the survey I designed draws on TPACK surveys used in the past for the examination of PK-6 grade PSTs, it does contain questions about content areas that pertain to 9-12 grades. To ensure this focus, I developed new and modified existing questions found in Schmidt et al.'s (2009) TPACK survey to more closely reflect teaching and content of 6-12th grade students which supported my research questions (See Appendix D, CTPACK section on survey). The addition of the Digital and Critical Digital Literacies domain questions and the modified questions mentioned above enhanced the richness of the data about graduate students' C-TPACKs. I scored each item response with a value ranging from 1 (strongly disagree) to 5 (strongly agree). For each domain question, the participants' responses were averaged which provided a macro look at the 58 students. The findings for that analysis are in Chapter 4. Each of the Phase 2 subset participant's C-TPACK was looked at independently and then compared across the subset in the findings and discussion sections in Chapter 4 as well.

\section{CDL open-ended questions.}

Open-ended questions that allowed the graduate students to indicate their critical digital literacy $(\mathrm{CDL})$ knowledge and understanding as it relates to technology integration are also included in this survey. The CDL questions were developed by this researcher. As explained earlier in my introduction and literature review, in their development of the TPACK construct, Koehler et al. (2013) emphasized the importance of considering the social and cultural contexts 
of digital environments when understanding technology integration. Selwyn (2010) stated that technology is "socially constructed and negotiated rather than imbued with pre-determined characteristics" (p. 65). I believe this warrants the inclusion of a critical lens when understanding how technology integration can be most effective in educational settings. These opinions, in conjunction with my study and understanding of CDL, led me to incorporate questions concerning graduate students' CDL knowledge alongside their TPACK. Consequently, I gained a stronger understanding of their choices regarding technology integration tools, activities, and goals for those lessons. Students' answers to these questions also provided insight about the relationship they see between technology integration practices and CDL and what value they give to CDL. This CDL inquiry aligned closely with my research questions.

This survey also contained a demographics section, which included gender, age, race/ethnicity, primary language spoken, level of education completed, family household income, and major at the university. This information provided descriptive information about the participants' personal characteristics and background (See Appendix D for the demographic questions).

In previous studies that utilized TPACK surveys, most used PSTs as the participants, and the results were largely used to predict the likelihood of technology integration once they entered the classroom as teachers (Chai et al., 2010; Koh \& Divaharan, 2011; Pamuk, 2012; Paratore, et al., 2016). I considered the possibility that the survey answers could be predictive; however, because I followed the teachers into the classroom, the survey answers were used to shed light on the teachers' beliefs about themselves and their practices rather than to predict what those actions would be. While consideration was given to whether and how those beliefs were reflected in their teaching practices, the survey served as only a component of my study. I believe that the 
Phase 2 data collection generated valuable information as it included lesson plan analysis and observations of practicing teachers which supported my research questions regarding the recruitment of C-TPACK to instruction practices.

\section{Phase 2}

As explained earlier, Phase 2 of this plan focused on graduate students who selfidentified as practicing teachers with moderate to high C-TPACK. As indicated in the Participants and Setting section above, my final sub-set of participants for Phase 2 included four practicing teachers. This phase of my study included lesson plan analysis, observations, and post-observation interviews.

\section{Lesson plans.}

From the sub-set of teachers, I asked permission to observe lessons they had planned that they believe include technology integration. Once granted permission to observe from the practicing teachers as well as their prospective school administration, I asked the teachers to provide their lesson plans that they believed included technology integration and/or CDL practices.

My reasons for collecting lesson plans were threefold. First, with guidance from my review of the literature, I assumed that graduate students who identify as having a moderate to high C-TPACK and a moderate to strong critical digital literacy understanding would be the most suitable participants for this study and were the most likely to recruit both in their teaching practices (Chai et al., 2010; Koh \& Divaharan, 2011; Pamuk, 2012; Paratore, et al., 2016). A second purpose was to identify another context in which the participants operated. Savin-Baden and Major (2013) explained that documents can provide valuable information about the people, purposes, and consequences of actions taken and not taken. They proposed that documents can 
serve as "a representation of information with the intent to communicate" (Savin-Baden \& Major, 2013). This was important in my study as I was examining the intentions of teachers to include technology integration and CDL and comparing that to actual practices. However, I was also aware that lesson plans may include materials and curriculum guidelines they have been required to use. Because of that, dominant discourses of others within the teachers' lesson plans could be an influence. This is further discussed in Limitations in Chapter 7.

To better understand the context of each teacher's lesson, after I observed the lesson of each teacher, I emailed them to ask for their unit plans within which those lessons took place. I felt I needed to better understand the context surrounding those lessons to be able to gain a stronger understanding of how each approached the content and also to have foundational knowledge about what led to those activities which could provide me with more information about the processes they used in their decision-making about technology integration. I believed it could also show if technology integration and CDL practices were just for the lesson I observed, or if they regularly incorporated CDL practices.

A third purpose for lesson plan analysis was triangulation with my observations and the teachers' C-TPACK survey answers. Lawless and Pellegino (2007) and Schrader and Lawless (2004) determined that relying solely on a teacher's self-assessed understanding and mastery of information more strongly reflected their confidence in working with that particular content area rather than an increase in putting that information into practice. As such, I included analysis of lesson plans as well as observation of lessons, which provided insight about how the teachers' beliefs and intentions actually were recruited to classroom practices. This information also directly spoke to RQ2: How does a subset of these graduate students who are also practicing teacher recruit their C-TPACK in their planning and instruction? 


\section{Classroom observations of teaching.}

Savin-Baden and Major (2013) explained that "observation is a way for a researcher to document everyday practices of participants and to better understand their experiences" (p. 392). Observations helped provide a context for this study as they connected teaching practices to the classroom setting moving this study from predictive to applicative. By observing in the classroom, I gained valuable knowledge about how the physical environment and the actors in that environment impacted the teacher's practices (Savin-Baden \& Major, 2013).

Using the teachers' lesson plans as my guide, I observed and documented how each of the four teachers executed his/her technology integration plans. My observations included a detailed account of the following: the physical setting, the participants, the activities, the tools and instruments used, other resources utilized for the delivery of information, teacher/student responses and interactions, evaluation techniques, and any debriefing activities. As explained in my literature review, I consider the definition of CDL to mean the understanding and creating of meaningfully representative digital texts. This includes the ability to examine the ideologies and sociocultural influences of digital environments that shape individual identities (Buckingham, 2003; Fuchs, 2014; Potter, 2012; Potter \& Banaji, 2011). I paid attention to Watulak and Kinzer's (2013) four components central to CDL practices. Those include:

- Understanding cultural, social, and historical contexts of technology use, including ethical and appropriate practices

- Recognizing that "understanding the broader, often less-visible frameworks that shape our interactions with technology has implications for the design of instruction at all levels" (p. 141)

- Critical thinking and analysis: 
- "Questioning their experiences around technology to develop more disciplined thinking about their technology use, informed by an understanding of both the technologies and their contexts of use" (p. 138)

- "Self-reflective understanding of your position and practices within a digital society that focuses on changing personal and professional practices rather than on uncovering power inequality and social injustice" (p. 139)

- Reflective practice:

- "Reflective practitioners must possess awareness of the social, cultural, and historical contexts and functional skills while also reflecting on their position and practices within these contexts and the outcomes of the uses of their functional skills" (p. 139)

- Functional skills with digital tools

- "The ability to manipulate technological tools for a specific purpose" (p. 141)

- "Identify and use appropriate technological tools to further their pedagogical and communicative goals" (p. 141).

Importantly, Watulak and Kinzer (2013) explained that "technologies are not value-neutral objects...we must understand that technology and its uses are both shaped by social and societal forces, and synergistically shape how we interact with and make meaning" (p. 140). As such, the four components of CDL practices reflect an awareness of how critical theory should be applied to digital environments. This understanding supports the "C" in CTPACK. 
According to Savin-Baden and Major (2013), my presence during the observation component represents participation. However, I tried to remain as unobtrusive as possible. In each case, I asked the teacher to allow me to be in the classroom in an area that was the least invasive to her/his space and that of the students. Just as with the inclusion of lesson plans, the inclusion of observations spoke to my second research question: How does a subset of these graduate students who are also practicing teacher recruit their C-TPACK in their planning and instruction?

\section{Interviews.}

I conducted an interview with each teacher after I completed my observation of him/her. Three of the interviews were conducted in person at the teachers' schools. Due to scheduling issues, one of the interviews was conducted via Skype. The interview protocol and question guide are located in Appendix E. I developed my interview questions to gain an understanding of how each teacher believed he/she was prepared to meaningfully and critically integrate technology into classroom practices. My intent was to understand how each teacher recruited those beliefs and preparations for such integration into his/her actual classroom practices. This included gaining an understanding of what they believed led to their decisions surrounding technology integration and critical digital literacy (CDL) practices and any barriers they may have faced while teaching. Including these interviews helped me answer my second and third research questions: (RQ2) How does a subset of these graduate students who are also practicing teacher recruit their C-TPACK in their planning and instruction? And (RQ3) What does this same subset of practicing teachers identify as the contributing factors that supported or hindered their abilities to engage the critical dimensions in their teaching? 
Before my interview with each teacher, I provided each with a copy of the definitions of the eight domains of knowledge that were on the survey. I did this because I would be comparing and analyzing their responses in the interviews with their responses to my survey. I wanted to ensure consistency about my terminology and how I defined those domains. I understood that my definitions were in no way universal, but they did provide a starting point for the conversation after which I encouraged them to provide their perspectives about those knowledge domains and their beliefs about their teaching practices in light of them.

The interviews were semi-structured and audio recorded. I created a list of guiding questions before I conducted observations (See Appendix E). After I reviewed the lesson plans and conducted the observations, I revised some of the questions and added some to reflect what I learned from each individual teacher's lesson plan and observation data. As such, I did not necessarily ask the same questions in every interview. This semi-structured interview approach allowed me the flexibility to more deeply probe for understanding of how each teacher recruited their C-TPACK and CDL. This approach also allowed me to ask clarification questions to ensure I was representing their voices and actions as accurately as possible. The interviews spanned in length from 50 minutes to one hour, five minutes.

\section{Data Analysis Procedures}

The analysis methods I used included descriptive statistics and qualitative coding. Creswell (2014) called this explanatory sequential mixed methods design. It involves the researcher collecting quantitative data which she then analyzes. Initial analysis results are used to build the second part of the study (Creswell, 2014). He stated: "The quantitative results typically inform the types of participants to be purposefully selected for the qualitative phase" (p. 224). In this study, I used the quantitative data analysis from Phase 1 in combination with qualitative 
data analysis of the open-ended questions on the same survey to help identify the sub-set of students who participated in Phase 2.

\section{Quantitative Analysis}

The quantitative data that I gathered were generated from the C-TPACK likert-scale survey answers. Quantitative analysis produced descriptive statistics that told me which students self-indicated the highest levels of C-TPACK. Descriptive statistics describe and present data in terms of the mean, median, mode, minimum and maximum scores, range and variance (Cohen, Manion, \& Morrison, 2007). While there is a degree of subjectivity in these data as the students self-indicated their C-TPACK, the statistics I generated from that data are objective in the sense that they do not include predictions or assumptions on my part (Cohen et al., 2007), but rather offer a snapshot in time of this pool of participants.

Additionally, I calculated the overall C-TPACK score for each student as suggested by the originators of the survey, Schmidt et al. (2009). Schmidt et al. (2009) explained that each item response is scored with a value ranging from " 1 " assigned for strongly disagree, to " 5 " for strongly agree. For each section, the participant's responses were averaged. For example, the six questions under TK (Technology Knowledge) were averaged to produce one TK (Technology Knowledge) Score. Those graduate students who scored the highest totals for each section of the C-TPACK survey were considered for the sub-set.

\section{Qualitative Analysis and Coding}

For the qualitative component of this study, I utilized First and Second Cycle coding to analyze the open-ended survey questions, lesson plans, my observations of the teachers, and the interview transcripts. The methods of coding that I used for this qualitative data included: Descriptive, In Vivo, and Process coding. From that coding I identified themes and categories. In 
addition, I utilized the Substitution, Augmentation, Modification, Redefinition (SAMR) model when analyzing the lesson plans and observations.

\section{First cycle coding.}

Saldana (2016) explained that First Cycle Coding "initially summarizes segments of data" (p. 236) and that the choice of coding method is determined by the type of data collected. In Vivo and Process Coding was used to analyze the open-ended survey questions, observations notes, and interviews. Descriptive Coding was used throughout data analysis primarily for organizing the data into categories. Saldana (2016) explained that Descriptive Coding is particularly helpful when multiple formats of data are collected as it generates strong lists of subtopics. Miles, Huberman, and Saldana (2014) stated that such coding is "more appropriate for social environments than social action" (p. 74); as the lesson plans served to describe the environment and potential activities, Descriptive Coding seemed fitting. Generally, the descriptive codes that are created are largely nouns and static in nature as opposed to Process Coding which generates a more dynamic representation of the data that may more strongly represent the participants voice, choices, and actions (Saldana, 2016).

\section{Descriptive coding.}

Descriptive Coding was used for analysis of the lesson plans. My descriptive codes provided me with specifics about how each teacher intended to integrate technology and engage in CDL. As this form of data is not action based, Descriptive Coding provided a foundational body of data that was used for comparative purposes later in the study (Saldana, 2016).

I used my Descriptive and In Vivo Coding (explained below) to develop construct tables that allowed me to compare each individual teacher's information across the different data formats including the open-ended questions, lesson plans, observations, and interviews. 
Table 3.2 includes an example of construct table showing descriptive coding from a lesson plan I analyzed.

Table 3.2

Lesson Plan Construct Table with Descriptive Coding

\begin{tabular}{lll}
\hline $\begin{array}{l}\text { Teacher's } \\
\text { Headings }\end{array}$ & Code & Memos \\
\hline "Class & "instruction" & $\begin{array}{l}\text { Her objective is defined in her class description - to instruct } \\
\text { students in writing }\end{array}$ \\
& "Writing" & $\begin{array}{l}\text { Included in middle school LA CCSS is the inclusion of } \\
\text { technology - implies she is "devoted" in some sense to } \\
\text { including technology. Motivated by standards to integrate } \\
\text { technology. }\end{array}$ \\
& standards" \\
& "Devoted" & Possibly "devoted" to the standards as well? \\
& "technology" & \\
\hline
\end{tabular}

\section{In Vivo coding.}

In Vivo Coding was used for analysis of the open-ended survey answers and the interviews. In Vivo Coding results in the development of concepts using the actual words of the participants (Corbin \& Strauss, 2015). Saldana (2016) explained that such coding "prioritizes and honors participants' voices" (p. 106). The open-ended survey questions elicited information from the participants about their personal experiences with technology integration and CDL practices. The questions specifically asked how they believed they had integrated technology and recruited CDL and also asked about experiences they had as students regarding professors' technology integration practices and professors' recruitment of CDL.

I also used In Vivo coding for interview transcript analysis. The interviews in this study provided valuable insight about the participants' teaching experiences and perspectives regarding technology integration practices and experiences. The questions provided teachers with the opportunity to reflect and expand upon their answers to the C-TPACK survey questions. The 
interviews provided me with insight about what they believed supported or hindered their abilities to engage the critical dimensions in their teaching. Both of which speak directly to my research questions. See Table 3.3 for an example of my In Vivo Coding. Saldana (2016) explained that In Vivo Coding captures the "behaviors or processes which will explain to the analyst how the basic problem of the actors is resolved or processed" (p. 109). This coding “prioritizes and honors" the participant's voice (Miles et al., 2014, p. 74), and understanding the teachers' experiences and perspectives with regard to technology integration and CDL are at the heart of my objectives for this study.

Table 3.3

In Vivo Coding from Andrew's Interview

\begin{tabular}{lll}
\hline Question & Code & Memo \\
\hline $\begin{array}{l}\text { In your doctorate degree, is that } \\
\text { primarily where you've had the most } \\
\text { technology integration training? }\end{array}$ & "Some classes" & \\
& $\begin{array}{l}\text { "Most of the stuff I've } \\
\text { picked up on" } \\
\text { "I'm interested in this" } \\
\text { "Run with it" }\end{array}$ & $\begin{array}{l}\text { Self-motivated with } \\
\text { technology } \\
\text { Driven by his interests } \\
\text { C-TPACK - able to find } \\
\text { and pick up new } \\
\text { technologies }\end{array}$ \\
& $\begin{array}{l}\text { "Domesticating } \\
\text { technology to what they're } \\
\text { doing" }\end{array}$ & $\begin{array}{l}\text { Making it fit into } \\
\text { everyday acts }\end{array}$ \\
\hline
\end{tabular}

\section{Process coding.}

I used Process Coding for analysis of the observations. Corbin and Strauss (2015) described Process Coding as searching the data for the ways that participants' actions, interactions, and reactions in settings serve "the purpose of reaching a goal or solving a problem" (p. 173). Charmaz (2014) explained that this type of coding "helps to define implicit meanings and actions" (p. 121) which can provide the researcher with opportunities to make comparisons 
across data sources potentially revealing emerging connections. As the primary purpose of conducting observations in this study was to examine how teachers moved from lesson plans to action in the classroom settings, the use of Process Coding led me to valuable connections across my data. Importantly, and as stated earlier, I recognized that while lesson plans may reflect teachers' intentions, they also reflect the systems or institutions have established as expectations for the lesson plans. Such structures and/or systems may be imposing dominant discourses within the curriculum, textbooks, materials, and standards that many teachers are required to use. 
Table 3.4

Example of Process Coding for Kate

\begin{tabular}{|c|c|}
\hline Code & Memo \\
\hline $\begin{array}{ll}\text { Evaluating } \\
\bullet \quad \text { Students' } \\
\text { digital } \\
\text { literacy }\end{array}$ & $\begin{array}{l}\text { I struggle with this as I did with using this word in the lesson plan coding. } \\
\text { In her lesson plans and while she was teaching, she uses words like "too } \\
\text { easy" and "should be familiar with" and "fairly fluent" - How does she } \\
\text { know this? From her experience, opinion, or based on what she knows } \\
\text { about the students previous work? } \\
\text { I still lean toward using "assuming" - but I am unsure if this is fair bc she } \\
\text { may have knowledge about the students that I do not know of (maybe has } \\
\text { done an assessment, had them take a tutorial, etc) }\end{array}$ \\
\hline Challenging & $\begin{array}{l}\text { She stated as a goal in her lesson plan to have students use new } \\
\text { technology tools }\end{array}$ \\
\hline $\begin{array}{l}\text { Collaborating } \\
\text { - with students } \\
\text { - With co } \\
\text { teacher }\end{array}$ & \\
\hline Student driven & \\
\hline $\begin{array}{ll}\text { Providing } \\
\qquad \quad \text { Gives } \\
\text { students } \\
\text { examples to } \\
\text { look at }\end{array}$ & $\begin{array}{l}\text { Should the "student choice" code come under this code instead - as she is } \\
\text { providing opportunities for students to choose... } \\
\text { If that were the case, I suppose "guiding" could come under this code as } \\
\text { well as she is providing guidance - this may make more sense as it would } \\
\text { show the juxtatposition of her actions which I believe creates some } \\
\text { tension or conflict in her mind about her teaching practices with } \\
\text { technology and CDL... }\end{array}$ \\
\hline
\end{tabular}

In Vivo and Process Coding aligned closely with my research questions. My goal was to gain an understanding of how graduate students believed they were prepared to meaningfully and critically integrate technology into their classroom practices. I also sought to understand what practicing teachers believed led to their decisions surrounding technology integration and critical digital literacy (CDL) practices and any supports/barriers they may have experienced when teaching. As such, participants' voices and perspectives can be strongly represented through In 
Vivo Coding. In addition, I wanted to understand how teachers recruited these beliefs and preparations for such integration into their actual classroom practices. Process Coding allowed me to represent the actions and interactions of the teachers in the classroom, which illustrated how the their lesson plans connected to their classroom practices. Process coding also allowed me to evaluate the lesson plans, classroom practices and their interviews to identify connecting themes.

\section{Second cycle coding.}

Second Cycle Coding is used as a means of accomplishing "categorical, thematic, conceptual and/or theoretical organization" of the data (Saldana, 2016). I engaged in themeing and categorizing the data for my Second Cycle Coding. Once I identified themes for each

teacher, I created concept maps to see how the data connected. See Figure 3.1 below for one of the concept maps. 


\section{Figure 3.1. Example of Themes and Concept Map}

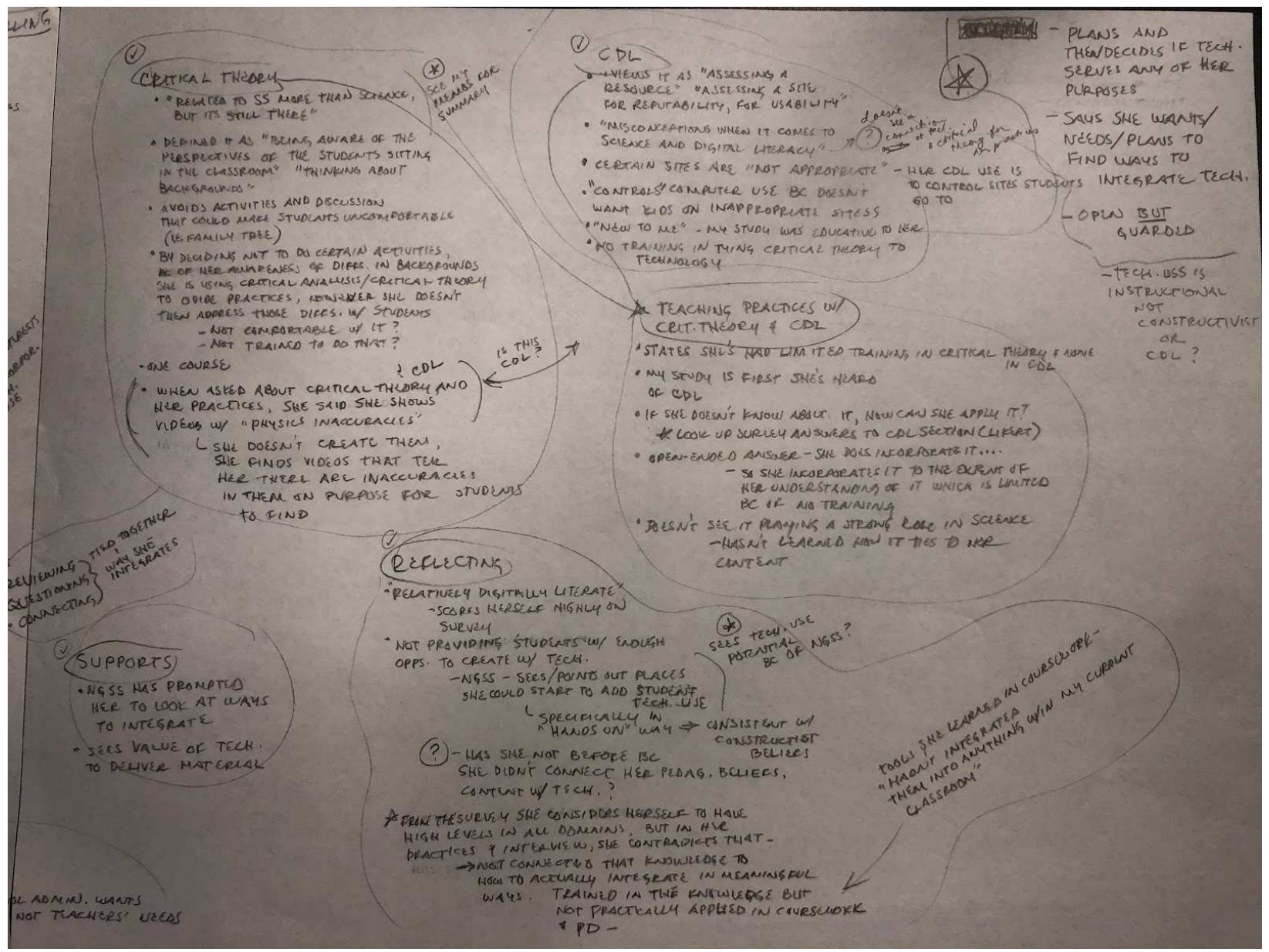

\section{"Themeing" the Data}

“Themeing" (p. 198) is described by Saldana (2016) as "an outcome of coding, categorization, and analytic reflection" (p.198) that is "an extended phrase or sentence that identifies what a unit of data is about and what it means" (p. 198). Taken further, the theme can represent what has happened and why something occurred the way it did (Miles et al., 2014; Saldana, 2016). Themes can be used to tie the data back to the theoretical framework of the study and the literature review.

First cycle coding allowed me to analyze the data sources independently. Second Cycle coding allowed me to analyze the relationships within and between the data. The richness of this 
data allowed me to identify a multitude of potential themes for each teacher. I prioritized those themes that most closely tied to RQ2 and RQ3. "Themeing" and categorizing helped me triangulate of all of the data sources and helped me determine areas where the data converged and diverged which increased the validity of this research (Miles et al., 2014). I continually and consistently used the C-TPACK framework, and both a social constructivist and constructivist grounded lens as I categorized the data into themes. Savin-Baden and Major (2013) explained that this practice of applying your theoretical framework to the data can "provide an initial structure for examining themes, whether compatible with or contrary to the framework" (p. 464).

\section{Four resources for multi-modal texts and SAMR models.}

An additional method of analysis that guided my data examination was application of the Four Resources Model for Multimodal Texts (Serafini, 2012) and the SAMR model (Puentedura, 2006). (See Table 3.5 and Figure 3.2, respectively). These models provide detailed descriptions of literacy practices as they relate to technology. 
Table 3.5

Four Resources for Multimodal Texts Model

All text below is taken directly from Serafini (2012).

\begin{tabular}{lcl}
\hline Reader as: & Literacy Practices: \\
\hline Navigator & $\bullet$ & Moves through both cognitive \& virtual space \\
& $\bullet$ & Readers navigate print-based and screen-based multimodal texts based on \\
& & their purposes for reading and the meanings readers construct in their \\
& transactions with these texts
\end{tabular}

- Decode written text accompanied by an understanding of the structures and codes associated with design, images, and other visual elements

- Understands the role and structures of charts, graphs, diagrams and other visual images encountered in multimodal texts

- Attends to the grammar of visual design

- Move in and out of non-linear structures, hypertext, and visual images

Interpreter $\quad$ Engages in the act or process of interpretation

- Constructs or generates viable meanings about what has been written by the author or depicted by the artist

- Generates responses to various texts and images

- Constructs understandings from multiple perspectives, including the author's intentions, textual references, personal experiences, and sociocultural contexts in which one reads

- Draws upon available resources to make sense of what is written or depicted

- Draws upon experiences with other images and texts during their act of interpretation

- Recognizes that images are not neutral or objective representations of reality

Designer

- Designs the way the text is read, its reading path, what is attended to, and, in the process constructs a unique experience during the transaction with a text

- Constructs multimodal texts

- Organizes what is to be navigated, interpreted and articulated, shaping available resources into potential meanings realized in the context of reading multimodal texts

- Understands the wider social conditions of production and reception and produces a text by selecting a site of appearance for the materialization of its intended meanings

- Recognizes that numerous reading paths are possible due to the non-linear nature of multimodal texts, but the path taken reflects the interests, needs, and experiences of the reader giving agency to the reader

- Frames the text by making decisions about which aspects of the texts are to be navigated to consider and interpret leading to design 


\begin{tabular}{lcl}
\hline Reader as: & Literacy Practices: \\
\hline Interrogator & $\bullet$ & Recognizes that meanings constructed during the act of reading are \\
& socially embedded, temporary, partial, and plural \\
& Explores and recognizes that images are produced within a system of \\
& social power and ideology \\
& Considers the larger, cultural meanings that multimodal texts evoke and \\
& the social, political, and cultural contexts in which they are viewed \\
& Infers meaning from various texts and contexts to interrogate what they \\
& read and view
\end{tabular}

(Table Ends)

Figure 3.2. SAMR MODEL

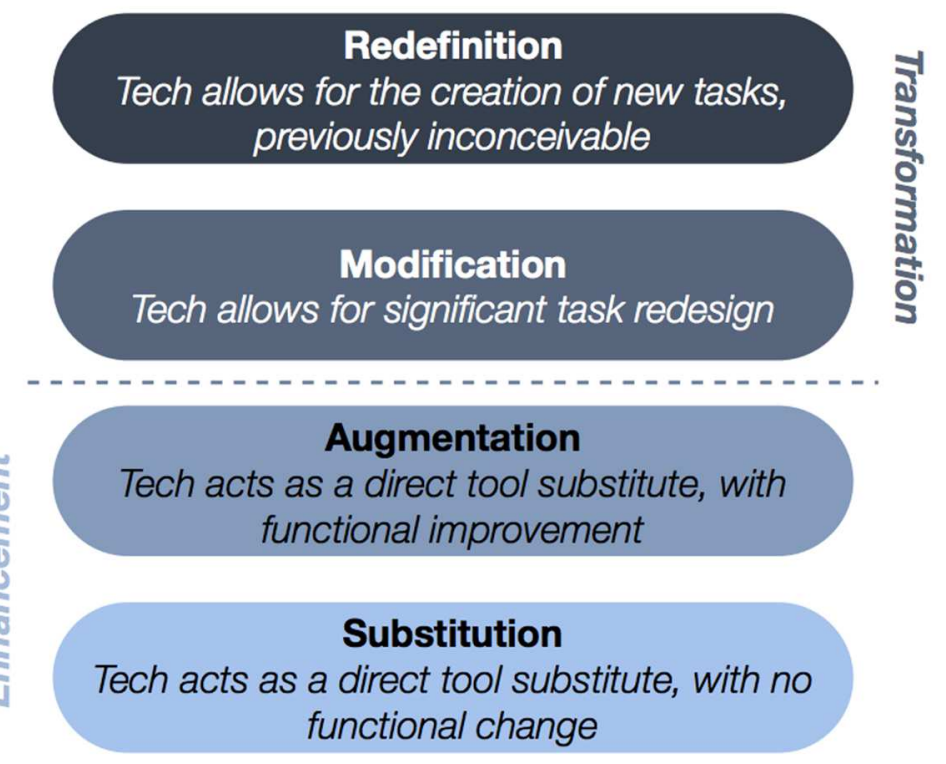


When developing the Four Resources Model for Multimodal Texts, Serafini (2012) reconsidered the four roles of the reader in Luke and Freebody's (1997) Four Resources model, which include: code breaker, text-participant, text user, text analyst. Luke and Freebody (1999) stated that their model was developed to help educators determine whether their literacy practices are addressing all of the textual uses that are needed to understand, navigate, and represent different cultures and economies. From their perspective,

critical literacies - in all their varied print and multimedia, practical and theoretical, cultural and political forms - refer to openings in the curriculum that enable teachers, students and communities to explore alternative ways of structuring practices around texts to address new cultural and economic contexts and new forms of practice and identity. (Luke \& Freebody, 1999, p. 3)

Serafini (2012) expanded Luke and Freebody's (1997) model by approaching the "reader as a reader as viewer (author's emphasis)" who attends to "the visual images, structures, and design elements of multimodal texts in addition to written language" (Serafini, 2012, p. 27). Serafini (2012) explained that the prevalence of multimodal texts in students' lives necessitates this expansion where the reader-viewer roles become: navigator, interpreter, designer, and interrogator (See Figure 3.5).

After studying both of the Four Resources models, and Serafini's (2012) expanded understanding in particular, I recognized that the strong presence of critical literacy as it applies to digital environments closely within those models aligned with my understanding of CDL. CDL includes the "understanding cultural, social, and historical contexts of technology use; critical thinking and analysis; reflective practice; and facility with the functional skills and tools of digital technology production (Watulak \& Kinzer, 2013, p. 128). In addition, I recognized that 
Luke and Freebody's understanding of literacy and Serafini's specific inclusion of literacy practices in digital environments aligned with my C-TPACK framework. As explained in Chapter 1, the C-TPACK framework prioritizes the recognition and critical analysis of the ideologies and social factors that are embedded in digital literacies; considers necessary the inclusion of new technologies in the understanding and valuing of the development of student literacy; recognizes the importance of connecting content, pedagogical, and technological knowledge to more meaningfully integrate technology; and values the participatory and collaborative practices of digital environments that contribute to student literacy. As such, using Serafini's model to examine my data supported the theoretical frameworks that provided the foundation for my study.

In addition to Serafini's model, I utilized the SAMR rubric developed by Puentedura (2006) to analyze lesson plans and observations. Specifically, the SAMR Model was developed as a way to ensure that learning with technology integration is personal, contextualized, and connected (Puentedura, 2006; Romrell et al., 2014). This model has been studied, developed and used as a means to ensure meaningful teacher technology integration practices that challenges students to reach the highest levels of Bloom's Taxonomy (Puentedura, 2006; Romrell et al., 2014). As the SAMR Model addresses the contexts involved in technology integration practices, it could be used to help shed light about a teacher's TPACK. Meaningful technology use happens at the transformative level where technology is used to create and redesign tasks and products. When looked at in light of Serafini's four resources model, the "Modification" and "Redefinition" levels support CDL practices, whereas "Substitution" and "Augmentation" support a functionalist use of technology. 
Using Serafini's and Puentedura's models as guides provided me with insight about the teachers' levels of engagement in the critical dimensions of technology use and meaningful technology integration practices respectively. Locating the teachers' practices within the models allowed me to focus on their C-TPACK recruitment before, during, and after their lessons. In previous TPACK research (Harris \& Hofer, 2014; Kihoza, Zloatnikova, Bada, \& Kalegele, 2016; Oakley and Pegrum, 2014), the Four Resources Model for Multimodal Texts (Serafini, 2012) and the SAMR (Puentedura, 2014) models have been utilized; however many of the previous predictive TPACK studies stopped short where my study continues. In this study, I analyzed both intentions and actual teaching practices to gain an understanding of how teachers recruited their C-TPACK to their planning and instruction which I believe provided valuable insight about processes teachers use with regards to the critical dimensions of technology integration practices.

I utilized the C-TPACK framework to guide my understanding and discussion of the categories and themes that were generated from the data. Incorporated within my C-TPACK framework is CDL. Watulak and Kinzer's (2013) four central elements within the CDL framework, which initially guided me in defining the critical digital literacy, or the "C," component of C-TPACK, served as sensitizing concepts that helped inform my inductive analysis of the data. In addition, as explained earlier, I also utilized the Four Resources Model for Multimodal Texts to help me identify the critical dimensions the teachers engaged in within their practices.

Understanding and prioritizing the contexts within which teachers practice was a priority for me when collecting and analyzing data as well as when reflecting about and developing my interpretations. Contextualized analysis is a key component of applying a constructivist grounded 
theory approach (Charmaz, 2014). Corbin and Strauss (2015) defined context as locating and explaining "action-interaction within a background of conditions and anticipated consequences. In doing so, it [context] links concepts and enhances a theory's ability to explain” (p. 268). Collecting multiple formats of data allowed me to gather information from the teachers in different contexts which, in turn, helped me more clearly understand the teacher's processes for recruiting their C-TPACK in their planning and instruction.

\section{Trustworthiness and Reflexivity}

Savin-Baden and Major (2013) explained the importance for researchers to "interrogate their deeply held beliefs" (p. 69) about issues that relate directly to their studies. Such interrogation can reveal a researcher's personal stances and positions about what is being studied as well as the individuals being studied. Knowing your stance and position is necessary as it can make you aware of potential biases that you bring to the study. Hay (2005) defines positionality as a researcher's "social, locational, and ideological placement relative to the research project or to other participants in it" (p. 290). Below, I address my positionality and the bias I brought to this study. I follow that with an explanation about how I addressed my reflexivity.

\section{Researcher Positionality and Bias}

Savin-Baden and Major (2013) presented the juxtaposition of stance and bias. They explained that a researcher's personal stance is a reflection of his/her priorities as defined by personal beliefs and opinions. This influences what is prioritized in his/her research. The choices a researcher makes in which data is significant is a reflection of that researcher's positions. For example, when coding an interview or observations, certain data is highlighted based on the researcher's opinions which rest on his/her priorities, assumptions and philosophical leanings (Creswell, 2014; Saldana, 2016; Savin-Baden \& Major, 2013). Not recognizing alternative 
positions and stances that can inadvertently impact interactions with the data and the participants and can lead to researcher bias. Accounting for researcher bias is a suggested means of increasing a study's trustworthiness (Creswell, 2014).

Including reflection notes while observing and after interviewing the teachers allowed me to express my feelings and perspectives about what I saw, heard, and focused on during observations and interviews. In doing so, I was able to ensure that I privileged the voices and perspectives of the teachers. For example, when I observed Diane, I made a note that it seemed contrary to a constructivist learning environment to have the students seated in rows and the teacher delivering the content for most of the class. This represents my position about how I believe learners best engage with each other and the material. It does not mean that Diane is not a constructivist necessarily, or that she doesn't believe in a collaborative and participatory learning environment. It simply means it is different than my approach to a teaching and learning environment. By reviewing my reflections during data analysis, I was able to identify and clarify which positions were mine versus those of the teachers.

\section{Approaches to researcher reflexivity.}

Bloor and Wood (2006) define reflexivity as "an awareness of the self in the situation of action and of the role of the self in constructing that situation" (p. 145). I developed my research questions based on my personal interests regarding how teachers recruit their C-TPACK. The notes I took during teacher observations helped me identify when/if and how a teacher recruited C-TPACK. My reflection notes within the observations revealed my positionality and allowed me to reflect on any biases I had towards the data. For example, when I observed Diane, one of the notes I made was "I wonder if arranging the seats in rows means that she uses traditional teaching methods?" When I coded the observation data and came across that note, I thought 
about my personal beliefs about traditional teaching methods and if I was imposing the idea that constructivist teaching practices must include seating students in groups or other "nontraditional" ways. This is obviously not the case, and as Diane demonstrated throughout her lesson, she did use constructivist teaching practices.

As I completed data analysis, I continually referred back to my theoretical framework and also my pedagogical beliefs about teaching and learning. Those notes allowed me to recognize my role in each engagement with the participants and helped me reflect about how my personal stance contributed to my interpretation of the data. The interviews gave me the opportunity to learn about the teacher's perspective concerning why or why not C-TPACK was recruited to classroom practices. This helped to counter biases I may have had about their practices.

To ensure I checked and considered biases that I may have brought to my study, I engaged in personal reflection throughout the study. This included incorporating self-reflection notes while observing, and making self-reflection notes about both the observations and the interviews as I analyzed the data. For example, while I observed Andrew teaching, I noted that he was using Quizlet as a form of technology integration and I remembered that inclusion in his lesson plan. Quizlet is a software application where the teacher generates questions beforehand that appear on a smartboard. Students were broken into teams to compete to see how many questions were answered correctly. Answers were discussed after each question. I also noted my feeling that this activity fell low on the Four Resources for Multi-Modal Texts and SAMR models and that I didn't see a critical digital element to the activity. However, noting my perceived absence a CDL objective reflected my personal stance about technology integration and CDL teaching practices. Through reflection, I recognized that it may not have be his objective for that activity. My objectives and hopes for technology integration and my theoretical 
perspective contain a CDL element that the teachers may or may not have. While there may have been an absence of CDL practices as I define them, that does not necessarily mean that the teacher does not have intentions for inclusion of CDL. It also does not mean the teacher has/hasn't considered CDL when developing lessons and teaching them. Further reflection such as this during my data analysis of notes I made during observations and after interviews helped direct my approach to analyzing my data.

As explained earlier in this chapter, my theoretical perspective includes constructivist grounded theory, where the researcher's findings do not "transcend experience but re-envision it" (Charmaz \& Mitchell, 1996, p. 299). With this approach, my reflections, what I witness, and what my thoughts about activities and actions were should work together to present the participants' lived experiences. This led me to revisit each interview transcript to determine what the teachers explained were their theoretical perspectives about teaching and learning.

\section{Reflexivity during writing.}

Upon advice given to me during proof-reading to look at the words and terms I was using that reflected behaviorist rather than constructivist beliefs, I found that I repeatedly used the word "training." A significant majority of the times I used that word was in direct relation to the studies that were examined in the Literature Review where previous researchers actually used the word themselves. Still, I had used it on my own as well. The use of this word, especially in a study about locating the critical component of the technology integration practices of teachers, provided me with valuable insight. Logically, the missing critical dimensions in studies about technology integration practices of the teachers is also not reflected in researchers' terminology. This poses a problem for researchers, like myself, who are trying to locate and study the critical components of technology integration practices because the greatest exposure to technology 
integration research also continually exposes researchers to a dominant discourse that could continue to be recruited to future research. This finding reflects the work by Selwyn (2012, 2015) and Henderson (2015) who claim that critical theory, while starting to be recruited to educational research, has been "at best, reflecting a dominant delusional ideology of education as a harmonious enterprise and, at worst, a disingenuous or willful ignorance of factors such as power relations, resistance, inequality, personal and socially negotiated histories and trajectories, and contested identities" (Henderson, 2015, p. 128). Reflexivity about why I used terminology that indexes this dominant discourse terminology, despite my having pedagogical, ontological, and epistemological beliefs that do not align with it, helped me come to this understanding and resulted in me working to ensure that my words reflected my beliefs.

There is tension in the field of research in educational technology where the emphasis has strongly been on a functionalist approach to understanding teaching practices with technology (Edmondson, 2002). Those researchers, like I initially did, fall back on the dominant discourse of functionalism that is so pervasive in previous studies and serves to perpetuate it, even in studies claiming to be applying critical theory. Using words such as "translate" and "training" reflect that dominant discourse. This shows the need to be conscious about the words used, as they do matter. It is the difference between a dusting of critical theory applied to an examination of teachers' technology integration practices versus an in-depth analysis resulting from digging deeply about personal beliefs and understandings of how critical theory can apply to teaching and learning with that technology.

My personal struggle to locate and then apply critical theory to educational technology research and teacher practices reflects this tension. Although in a different context, this tension is also reflected in the struggles the teachers in this study faced where they had dedicated time, 
attention, thought and practice to understanding their own pedagogical beliefs surrounding their content areas, but continually fell back to traditionalist approaches and methods in their uses of technology with students during instruction. This showed a disconnect between their constructivist beliefs and/or leanings, their beliefs about their understanding of critical theory and CDL, and their recruitment of those pedagogical beliefs and critical theory to their instructional practices. Avila and Pandya (2013) stated: "Critical literacies themselves can be intimidating to educators, but to couple them with digital literacies and ask teachers to figure out how to integrate the whole complete mess in an educational context that values measurable and testable skills (neither of which these are) often leaves us with present and future educators who are reluctant to engage with either the critical or the digital" (Avila \& Pandya, 2013, p. 6).

Falling back on traditionalist approaches to technology integration led, once again, to functionalist terminology and functionalist practices in both the case of my personal journey as well as the teachers', respectively. My use of functionalist words such as "translate" and "training" in a study whose framework emphasized social constructivism and a CDL framework provides an example of this struggle to consistently and consciously be aware of the dominant discourses that can circle back into practices, resulting in not moving "from rhetoric to reality" (Henderson, 2015, p. 128). It is the meaningful and critical technology integration practices that are hindered by such an approach where constructivism and critical theory may be at the center of a teacher's or researcher's pedagogical beliefs, but a focus on functionalism in teacher education, teacher development programs, and educational technology research results in the continuation of that dominant discourse and practices that reflect it.

In addition, had this contradiction and tension in this study not been recognized, this study could have served as an example of the concern that is often posed about combining 
postpostivist and constructivist paradigms in mixed methods studies. This prioritizes the need to recognize that words and practices are connected. This study showed the importance for educational technology researchers who use critical theoretical frameworks to continually reflect upon their positionalities and biases to gain a stronger awareness of how they have been, and could still be, being influenced by the very dominant discourses they are working to uncover and address.

\section{Member Checking}

As I coded and themed the data, I continually wrote analytic memos to serve as a critical reflection, expand upon findings, and provide direction through questions I had, and connections I made. The memos served as a place to record issues and/or problems I came across as well as enabled me to address and challenge personal assumptions and how they impact my research (Miles et al., 2014; Saldana, 2016). For example, in Table 3.3 below, I wrote about my initial interpretations of one of the teacher's practices and included questions to address my view and to guide my interview questions to ensure her perspective was considered. 
Table 3.6

Coding with Memos from Observations of Diane

\begin{tabular}{|c|c|}
\hline Observation & Memo \\
\hline $\begin{array}{l}\text { Teacher talks to students during video and } \\
\text { explains concepts while they are also } \\
\text { supposed to be completing the worksheet }\end{array}$ & $\begin{array}{l}\text { Students have a lot to attend to at the same time - } \\
\text { video, notes, questions on worksheet, teacher } \\
\text { explanations during video }\end{array}$ \\
\hline Chromebooks are used after worksheets are & Control of technology \\
\hline given to get to website & Do they not know how to do this on their own? \\
\hline \multirow[t]{3}{*}{ Turn in worksheets, turn in Chromebooks } & $\begin{array}{l}\text { Worksheet is traditional delivery method and now } \\
\text { she is using Chromebooks - substitution? } \\
\text { Control of technology; classroom management? }\end{array}$ \\
\hline & $\begin{array}{l}\text { Control of technology - if they are } 1: 1 \text {, do they not } \\
\text { get to take the books home with them or between } \\
\text { classes? How does she feel about this? }\end{array}$ \\
\hline & $\begin{array}{l}\text { Different schools/districts implement } 1: 1 \\
\text { differently. It seemed like this school/district has } \\
\text { strong guidelines about technology use. }\end{array}$ \\
\hline
\end{tabular}

I followed my review of the interview transcripts with emails to each teacher containing excerpts in their own words about what each identified as their teaching approach. I asked each teacher to briefly explain their beliefs again to me, in more detail if possible, so that I could be sure I honored their perspectives. I also added follow up questions asking them to expand as necessary for clarification.

In addition, I engaged in member-checking of my findings from the interviews to ensure that I accurately represented the participants. Member-checking is considered a validity strategy to ensure the accuracy of qualitative findings where participants are provided with descriptions or themes the researcher identified and asked to corroborate those findings (Creswell, 2014). 
After each interview, I listened back to the recordings and wrote down clarification questions. Two of the four teachers responded to emails asking them to review themes and provide additional information about questions I had about their responses. In addition, as I had questions when coding the data, I emailed the teachers to provide clarification about their answers.

\section{Concluding Thoughts}

My objectives for this study align with Strauss and Corbin's (1997) assertion that "Theorizing is the act of constructing...from data an explanatory scheme that systematically integrates various concepts through statements of relationship" (p. 25). Coding of the participant data prioritizes the researcher's interpretation of the data, thus producing additional information for the study (Savin-Baden \& Howell-Major, 2013). In this sense, I am acknowledging that my values and beliefs are an "inevitable part of the outcome" (Mills, Bonner, \& Francis, 2006, p. 26). Such outcomes are considered a valuable result of employing constructivist grounded theory. They can result in a reciprocal and greater understanding of the experiences of the participants and lead to theory construction from the data (Charmaz, 2014). 


\section{CHAPTER IV: QUANTITATIVE ANALYSIS AND FINDINGS}

The purpose of this chapter is to answer RQ1 by presenting the quantitative analysis and findings from the C-TPACK likert-scale question answers. All 58 students answered each and every knowledge domain likert scale question. Below, I begin by presenting the statistical analysis of the C-TPACK of Phase 1 participants. Next, I explain the findings from the CTPACK surveys of the Phase 1 participants and discuss how the subset of participants for Phase 2 were identified. Finally, I discuss the Phase 2 subset of participants and explain my consideration of the quantitative data gathered in this study in combination with qualitative data.

\section{C-TPACK of Phase 1 Participants}

The figures below provide the findings for each of the eight knowledge domains for the pool of 58 students. Included with each figure are the definitions about the domain that were provided to the students within the survey. (See Appendix D for survey). As mentioned earlier, all 58 students answered all questions in all of the knowledge domain sections of this survey.

\section{Phase 1 Participants}

Mishra and Koehler (2006) explained that Technology Knowledge (TK) is an understanding of how to productively apply technology tools in an individual's work and everyday life. This includes the ability to recognize when technology assists or hinders the accomplishment of a goal. Such knowledge helps a person accomplish a variety of different tasks using the technology, as well as to know different ways to accomplishing a given task (Mishra \& Koehler, 2006). Figure 4.1 below shows the results for these questions. 
Figure 4.1. Technology Knowledge

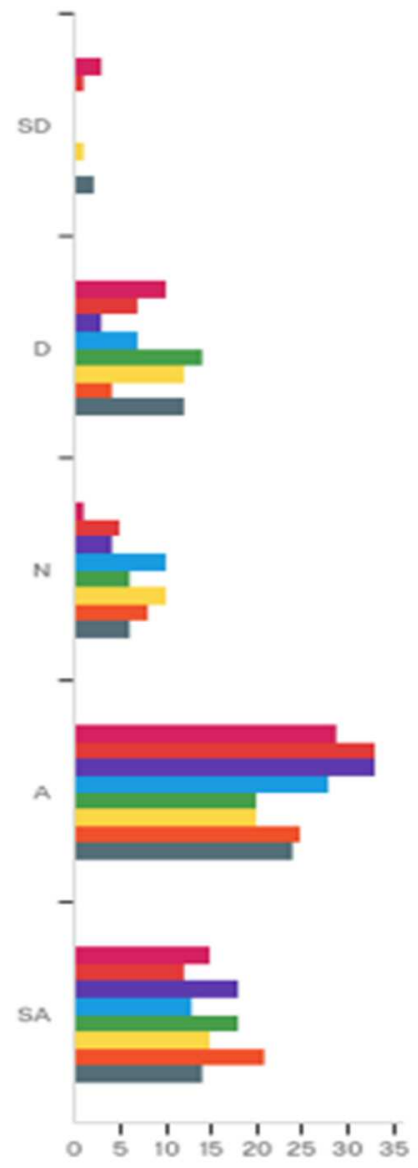

I have heard of this term (Technology Knowledge) before and it is a familia.. I know how to solve my own technical problems.

I can learn technology easily.

I 1 keep up with important new technologies.

I I frequently play around with technology.

II I know about a lot of different technologies.

I I have the technical skills I need to use technology.

I I have had sufficient opportunities to work with different technologies. 


\begin{tabular}{rrrrrrr}
\hline Field & Minimum & Maximum & Mean & $\begin{array}{c}\text { Std } \\
\text { Deviation }\end{array}$ & Variance & Count \\
\hline $1 \quad \begin{array}{r}\text { I have heard of this } \\
\text { term (Technology } \\
\text { Knowledge) before } \\
\text { and it is a familiar } \\
\text { idea to me. }\end{array}$ & 1.00 & 5.00 & 3.74 & 1.17 & 1.36 & 58 \\
$\quad$ I know how to solve \\
my own technical \\
problems.
\end{tabular}




\begin{tabular}{|c|c|c|c|c|c|c|c|c|c|c|c|c|}
\hline \# & Question & SD & & D & & $\mathbf{N}$ & & A & & SA & & Total \\
\hline 1 & $\begin{array}{r}\text { I have heard } \\
\text { of this term } \\
\text { (Technology } \\
\text { Knowledge) } \\
\text { before and it is } \\
\text { a familiar idea } \\
\text { to me. }\end{array}$ & $5.17 \%$ & 3 & $17.24 \%$ & 10 & $1.72 \%$ & 1 & $50.00 \%$ & 29 & $25.86 \%$ & 15 & 58 \\
\hline 2 & $\begin{array}{r}\text { I know how to } \\
\text { solve my own } \\
\text { technical } \\
\text { problems. }\end{array}$ & $1.72 \%$ & 1 & $12.07 \%$ & 7 & $8.62 \%$ & 5 & $56.90 \%$ & 33 & $20.69 \%$ & 12 & 58 \\
\hline 3 & $\begin{array}{r}\text { I can learn } \\
\text { technology } \\
\text { easily. }\end{array}$ & $0.00 \%$ & 0 & $5.17 \%$ & 3 & $6.90 \%$ & 4 & $56.90 \%$ & 33 & $31.03 \%$ & 18 & 58 \\
\hline 4 & $\begin{array}{l}\text { I keep up with } \\
\text { important new } \\
\text { technologies. }\end{array}$ & $0.00 \%$ & 0 & $12.07 \%$ & 7 & $17.24 \%$ & 10 & $48.28 \%$ & 28 & $22.41 \%$ & 13 & 58 \\
\hline 5 & $\begin{array}{r}\text { I frequently } \\
\text { play around } \\
\text { with } \\
\text { technology. }\end{array}$ & $0.00 \%$ & 0 & $24.14 \%$ & 14 & $10.34 \%$ & 6 & $34.48 \%$ & 20 & $31.03 \%$ & 18 & 58 \\
\hline 6 & $\begin{array}{c}\text { I know about a } \\
\text { lot of different } \\
\text { technologies. }\end{array}$ & $1.72 \%$ & 1 & $20.69 \%$ & 12 & $17.24 \%$ & 10 & $34.48 \%$ & 20 & $25.86 \%$ & 15 & 58 \\
\hline 7 & $\begin{array}{r}\text { I have the } \\
\text { technical skills } \\
\text { I need to use } \\
\text { technology. }\end{array}$ & $0.00 \%$ & 0 & $6.90 \%$ & 4 & $13.79 \%$ & 8 & $43.10 \%$ & 25 & $36.21 \%$ & 21 & 58 \\
\hline 8 & $\begin{array}{r}\text { I have had } \\
\text { sufficient } \\
\text { opportunities } \\
\text { to work with } \\
\text { different } \\
\text { technologies. }\end{array}$ & $3.45 \%$ & 2 & $20.69 \%$ & 12 & $10.34 \%$ & 6 & $41.38 \%$ & 24 & $24.14 \%$ & 14 & 58 \\
\hline
\end{tabular}


Below, Figure 4.2 show the beliefs students had about their Content Knowledge. Mishra and Koehler (2006) explained that Content Knowledge (CK) is a teacher's knowledge about the subject matter to be learned or taught. Analysis of these results showed that most of the students believed they had a high level of CK.

Figure 4.2. Content Knowledge

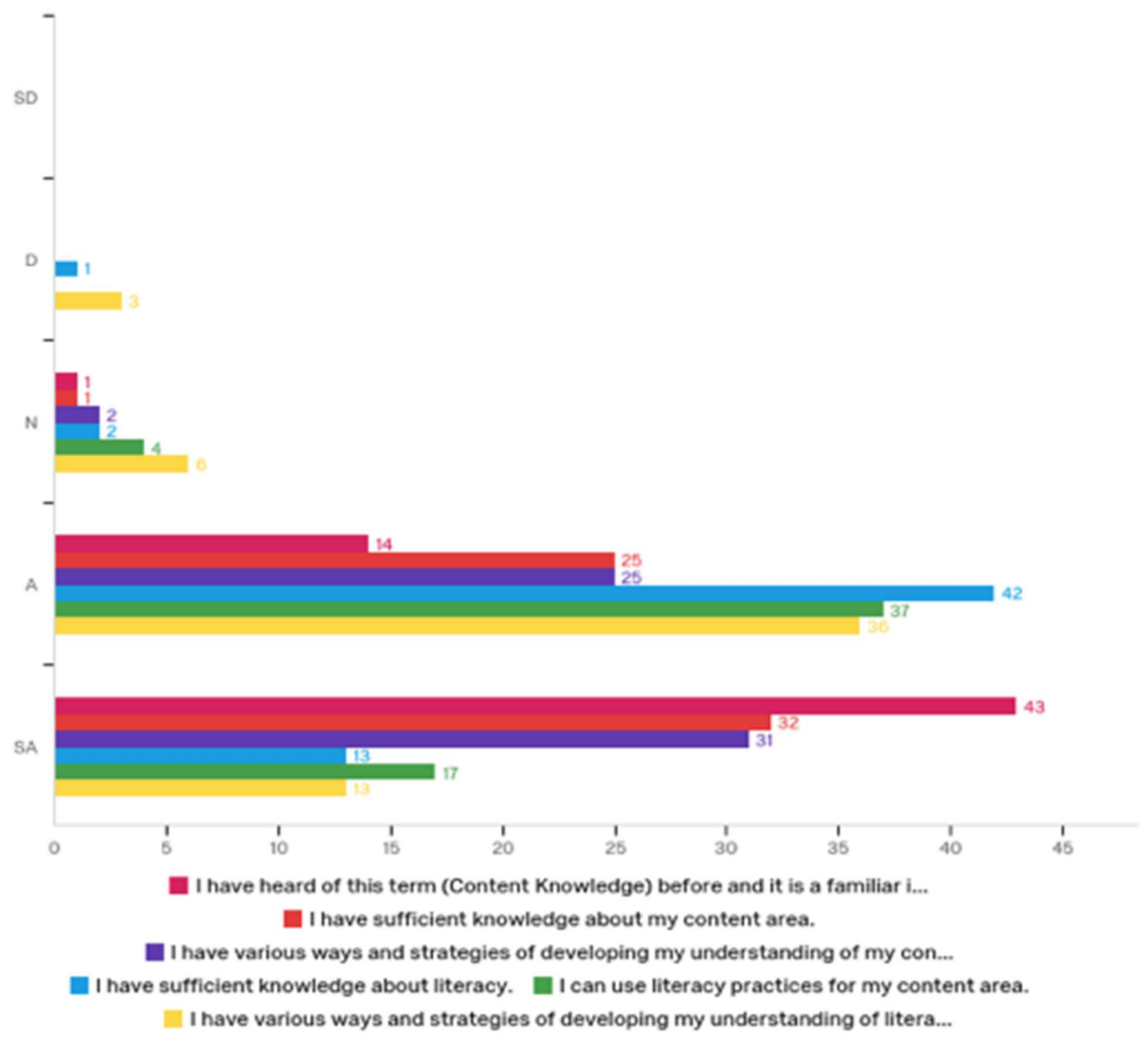




\begin{tabular}{|c|c|c|c|c|c|c|c|c|c|c|c|c|}
\hline \# & Question & SD & & D & & $\mathbf{N}$ & & $\mathbf{A}$ & & SA & & Total \\
\hline 1 & $\begin{array}{r}\text { I have heard } \\
\text { of this term } \\
\text { (Content } \\
\text { Knowledge) } \\
\text { before and it } \\
\text { is a familiar } \\
\text { idea to me. }\end{array}$ & $0.00 \%$ & 0 & $0.00 \%$ & 0 & $1.72 \%$ & 1 & $24.14 \%$ & 14 & $74.14 \%$ & 43 & 58 \\
\hline 2 & $\begin{array}{r}\text { I have } \\
\text { sufficient } \\
\text { knowledge } \\
\text { about my } \\
\text { content area. }\end{array}$ & $0.00 \%$ & 0 & $0.00 \%$ & 0 & $1.72 \%$ & 1 & $43.10 \%$ & 25 & $55.17 \%$ & 32 & 58 \\
\hline 3 & $\begin{array}{r}\text { I have various } \\
\text { ways and } \\
\text { strategies of } \\
\text { developing } \\
\text { my } \\
\text { understanding } \\
\text { of my content } \\
\text { area. }\end{array}$ & $0.00 \%$ & 0 & $0.00 \%$ & 0 & $3.45 \%$ & 2 & $43.10 \%$ & 25 & $53.45 \%$ & 31 & 58 \\
\hline 4 & $\begin{array}{r}\text { I have } \\
\text { sufficient } \\
\text { knowledge } \\
\text { about literacy. }\end{array}$ & $0.00 \%$ & 0 & $1.72 \%$ & 1 & $3.45 \%$ & 2 & $72.41 \%$ & 42 & $22.41 \%$ & 13 & 58 \\
\hline 5 & $\begin{array}{r}\text { I can use } \\
\text { literacy } \\
\text { practices for } \\
\text { my content } \\
\text { area. }\end{array}$ & $0.00 \%$ & 0 & $0.00 \%$ & 0 & $6.90 \%$ & 4 & $63.79 \%$ & 37 & $29.31 \%$ & 17 & 58 \\
\hline 6 & $\begin{array}{r}\text { I have various } \\
\text { ways and } \\
\text { strategies of } \\
\text { developing } \\
\text { my } \\
\text { understanding } \\
\text { of literacy. }\end{array}$ & $0.00 \%$ & 0 & $5.17 \%$ & 3 & $10.34 \%$ & 6 & $62.07 \%$ & 36 & $22.41 \%$ & 13 & 58 \\
\hline
\end{tabular}




\begin{tabular}{|c|c|c|c|c|c|c|c|}
\hline$\#$ & Field & Minimum & Maximum & Mean & $\begin{array}{c}\text { Std } \\
\text { Deviation }\end{array}$ & Variance & Count \\
\hline 1 & $\begin{array}{l}\text { I have heard } \\
\text { of this term } \\
\text { (Content } \\
\text { Knowledge) } \\
\text { before and it } \\
\text { is a familiar } \\
\text { idea to me. }\end{array}$ & 3.0 & 5.00 & 4.72 & 0.48 & 0.23 & 58 \\
\hline 2 & $\begin{array}{l}\text { I have } \\
\text { sufficient } \\
\text { knowledge } \\
\text { about my } \\
\text { content area. }\end{array}$ & 3.0 & 5.00 & 4.53 & 0.53 & 0.28 & 58 \\
\hline 3 & $\begin{array}{l}\text { I have various } \\
\text { ways and } \\
\text { strategies of } \\
\text { developing } \\
\text { my } \\
\text { understanding } \\
\text { of my content } \\
\text { area. }\end{array}$ & 3.0 & 5.00 & 4.50 & 0.56 & 0.32 & 58 \\
\hline 4 & $\begin{array}{l}\text { I have } \\
\text { sufficient } \\
\text { knowledge } \\
\text { about } \\
\text { literacy. }\end{array}$ & 2.0 & 5.00 & 4.16 & 0.55 & 0.30 & 58 \\
\hline 5 & $\begin{array}{l}\text { I can use } \\
\text { literacy } \\
\text { practices for } \\
\text { my content } \\
\text { area. }\end{array}$ & 3.0 & 5.00 & 4.22 & 0.56 & 0.31 & 58 \\
\hline 6 & $\begin{array}{l}\text { I have various } \\
\text { ways and } \\
\text { strategies of } \\
\text { developing } \\
\text { my } \\
\text { understanding } \\
\text { of literacy. }\end{array}$ & 2.0 & 5.00 & 4.02 & 0.73 & 0.53 & 58 \\
\hline
\end{tabular}

Next, Figure 4.3 presents the students' beliefs about their Pedagogical Knowledge. Mishra and Koehler (2006) stated that Pedagogical Knowledge (PK) is a teacher's in depth knowledge about the processes and practices or methods of teaching and learning. This includes 
a teacher's beliefs about educational purposes, values, and aims. The PK of a teacher incorporates knowledge about techniques or methods used in the classroom and strategies for evaluating student understanding (Mishra \& Koehler, 2006). The results showed the students largely believed they had a high level of PK.

\section{Figure 4.3. Pedagogical Knowledge}

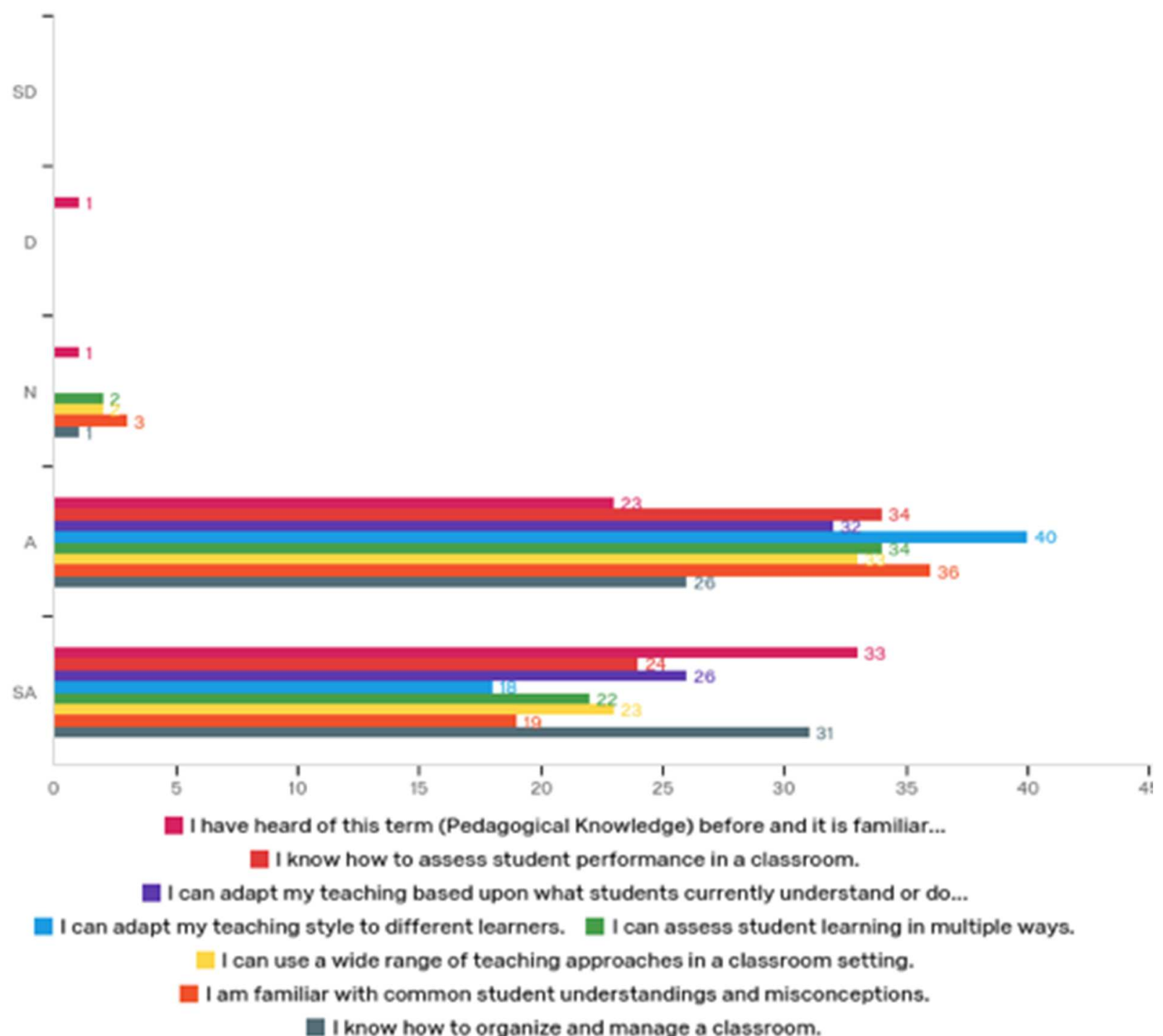




\begin{tabular}{|c|c|c|c|c|c|c|c|}
\hline$\#$ & Field & Minimum & Maximum & Mean & $\begin{array}{l}\text { Std } \\
\text { Deviation }\end{array}$ & Variance & Count \\
\hline 1 & $\begin{array}{l}\text { I have heard of } \\
\text { this term } \\
\text { (Pedagogical } \\
\text { Knowledge) } \\
\text { before and it is } \\
\text { familiar to me. }\end{array}$ & 2.00 & 5.00 & 4.52 & 0.62 & 0.39 & 58 \\
\hline 2 & $\begin{array}{l}\text { I know how to } \\
\text { assess student } \\
\text { performance in } \\
\text { a classroom. }\end{array}$ & 4.00 & 5.00 & 4.41 & 0.49 & 0.24 & 58 \\
\hline 3 & $\begin{array}{l}\text { I can adapt my } \\
\text { teaching based } \\
\text { upon what } \\
\text { students } \\
\text { currently } \\
\text { understand or } \\
\text { do not } \\
\text { understand. }\end{array}$ & 4.00 & 5.00 & 4.45 & 0.50 & 0.25 & 58 \\
\hline 4 & $\begin{array}{l}\text { I can adapt my } \\
\text { teaching style } \\
\text { to different } \\
\text { learners. }\end{array}$ & 4.00 & 5.00 & 4.31 & 0.46 & 0.21 & 58 \\
\hline 5 & $\begin{array}{l}\text { I can assess } \\
\text { student learning } \\
\text { in multiple } \\
\text { ways. }\end{array}$ & 3.00 & 5.00 & 4.34 & 0.54 & 0.29 & 58 \\
\hline 6 & $\begin{array}{l}\text { I can use a wide } \\
\text { range of } \\
\text { teaching } \\
\text { approaches in a } \\
\text { classroom } \\
\text { setting. }\end{array}$ & 3.00 & 5.00 & 4.36 & 0.55 & 0.30 & 58 \\
\hline 7 & $\begin{array}{l}\text { I am familiar } \\
\text { with common } \\
\text { student } \\
\text { understandings } \\
\text { and } \\
\text { misconceptions. }\end{array}$ & 3.00 & 5.00 & 4.28 & 0.55 & 0.30 & 58 \\
\hline 8 & $\begin{array}{l}\text { I know how to } \\
\text { organize and } \\
\text { manage a } \\
\text { classroom. }\end{array}$ & 3.00 & 5.00 & 4.52 & 0.53 & 0.28 & 58 \\
\hline
\end{tabular}




\begin{tabular}{|c|c|c|c|c|c|c|c|c|c|c|c|c|}
\hline \# & Question & SD & & D & & $\mathbf{N}$ & & $\mathbf{A}$ & & SA & & Total \\
\hline 1 & $\begin{array}{r}\text { I have heard of } \\
\text { this term } \\
\text { (Pedagogical } \\
\text { Knowledge) } \\
\text { before and it is } \\
\text { familiar to me. }\end{array}$ & $0.00 \%$ & 0 & $1.72 \%$ & 1 & $1.72 \%$ & 1 & $39.66 \%$ & 23 & $56.90 \%$ & 33 & 58 \\
\hline 2 & $\begin{array}{r}\text { I know how to } \\
\text { assess student } \\
\text { performance in a } \\
\text { classroom. }\end{array}$ & $0.00 \%$ & 0 & $0.00 \%$ & 0 & $0.00 \%$ & 0 & $58.62 \%$ & 34 & $41.38 \%$ & 24 & 58 \\
\hline 3 & $\begin{array}{r}\text { I can adapt my } \\
\text { teaching based } \\
\text { upon what } \\
\text { students } \\
\text { currently } \\
\text { understand or do } \\
\text { not understand. }\end{array}$ & $0.00 \%$ & 0 & $0.00 \%$ & 0 & $0.00 \%$ & 0 & $55.17 \%$ & 32 & $44.83 \%$ & 26 & 58 \\
\hline 4 & $\begin{array}{r}\text { I can adapt my } \\
\text { teaching style to } \\
\text { different } \\
\text { learners. }\end{array}$ & $0.00 \%$ & 0 & $0.00 \%$ & 0 & $0.00 \%$ & 0 & $68.97 \%$ & 40 & $31.03 \%$ & 18 & 58 \\
\hline 5 & $\begin{array}{r}\text { I can assess } \\
\text { student learning } \\
\text { in multiple ways. }\end{array}$ & $0.00 \%$ & 0 & $0.00 \%$ & 0 & $3.45 \%$ & 2 & $58.62 \%$ & 34 & $37.93 \%$ & 22 & 58 \\
\hline 6 & $\begin{array}{r}\text { I can use a wide } \\
\text { range of teaching } \\
\text { approaches in a } \\
\text { classroom } \\
\text { setting. }\end{array}$ & $0.00 \%$ & 0 & $0.00 \%$ & 0 & $3.45 \%$ & 2 & $56.90 \%$ & 33 & $39.66 \%$ & 23 & 58 \\
\hline 7 & $\begin{array}{r}\text { I am familiar } \\
\text { with common } \\
\text { student } \\
\text { understandings } \\
\text { and } \\
\text { misconceptions. }\end{array}$ & $0.00 \%$ & 0 & $0.00 \%$ & 0 & $5.17 \%$ & 3 & $62.07 \%$ & 36 & $32.76 \%$ & 19 & 58 \\
\hline 8 & $\begin{array}{r}\text { I know how to } \\
\text { organize and } \\
\text { manage a } \\
\text { classroom. }\end{array}$ & $0.00 \%$ & 0 & $0.00 \%$ & 0 & $1.72 \%$ & 1 & $44.83 \%$ & 26 & $53.45 \%$ & 31 & 58 \\
\hline
\end{tabular}


In Figure 4.4, the graduate students' answers about their Pedagogical Content Knowledge (PCK) is presented. Mishra and Koehler (2006) explained that PK is a teacher's knowledge that helps him/her interpret subject matter, find multiple ways to represent it, and customize the instructional materials in ways that can access students' prior knowledge.

\section{Figure 4.4. Pedagogical Content Knowledge}

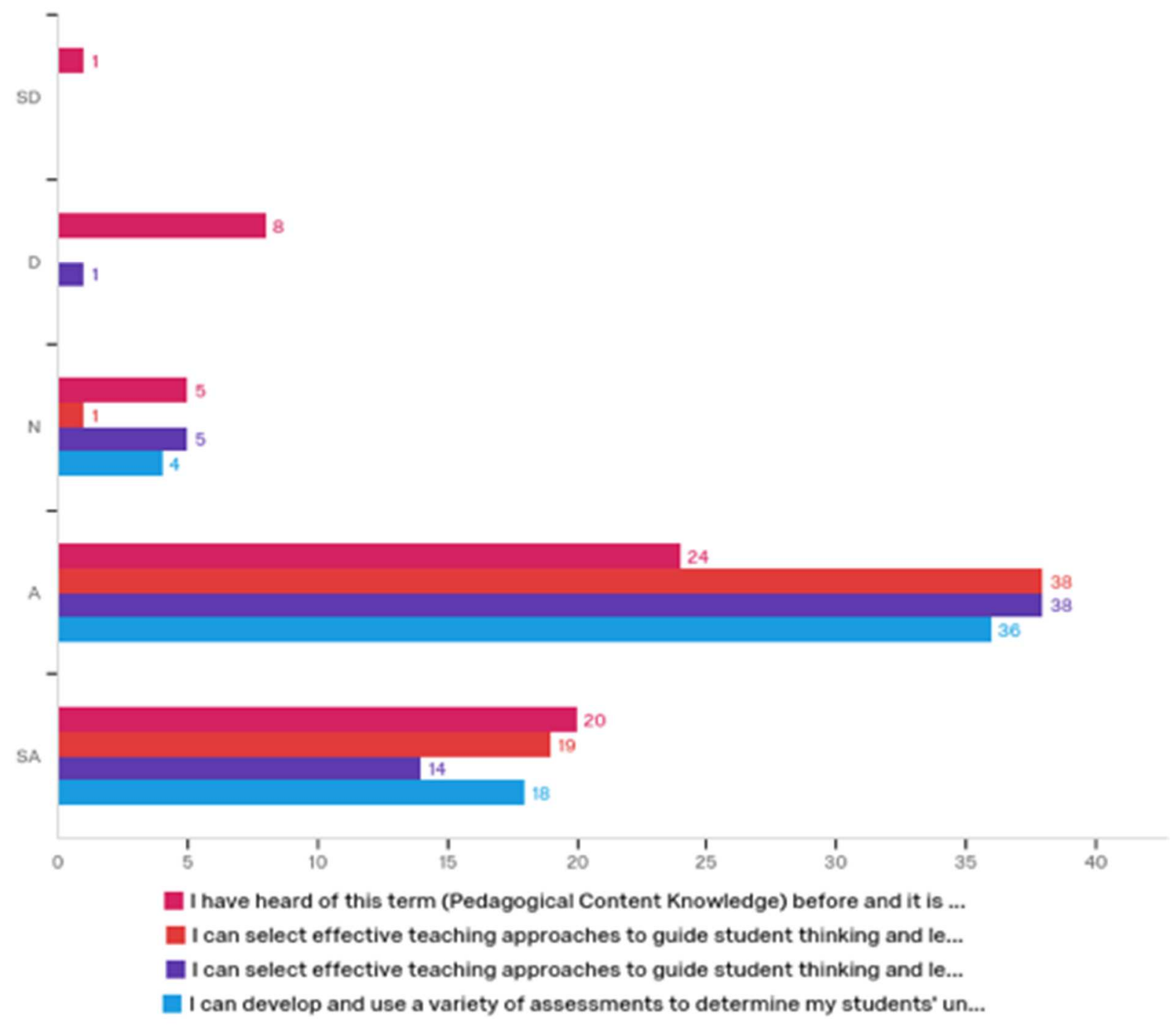




\begin{tabular}{|c|c|c|c|c|c|c|c|}
\hline \# & Field & Minimum & Maximum & Mean & $\begin{array}{l}\text { Std } \\
\text { Deviation }\end{array}$ & Variance & Count \\
\hline 1 & $\begin{array}{l}\text { I have heard of this } \\
\text { term (Pedagogical } \\
\text { Content Knowledge) } \\
\text { before and it is a } \\
\text { familiar idea to me. }\end{array}$ & 1.00 & 5.00 & 3.93 & 1.06 & 1.13 & 58 \\
\hline 2 & $\begin{array}{l}\text { I can select effective } \\
\text { teaching approaches to } \\
\text { guide student thinking } \\
\text { and learning in my } \\
\text { content area. }\end{array}$ & 3.00 & 5.00 & 4.31 & 0.50 & 0.25 & 58 \\
\hline 3 & $\begin{array}{l}\text { I can select effective } \\
\text { teaching approaches to } \\
\text { guide student thinking } \\
\text { and learning in } \\
\text { literacy. }\end{array}$ & 2.00 & 5.00 & 4.12 & 0.62 & 0.38 & 58 \\
\hline 4 & $\begin{array}{r}\text { I can develop } \\
\text { and use a variety of } \\
\text { assessments to } \\
\text { determine my students' } \\
\text { understandings of } \\
\text { content. }\end{array}$ & 3.00 & 5.00 & 4.24 & 0.57 & 0.32 & 58 \\
\hline
\end{tabular}




\begin{tabular}{|c|c|c|c|c|c|c|c|c|c|c|c|c|}
\hline \# & Question & SD & & D & & $\mathbf{N}$ & & $\mathbf{A}$ & & $\mathbf{S A}$ & & Total \\
\hline 1 & $\begin{array}{r}\text { I have heard of } \\
\text { this term } \\
\text { (Pedagogical } \\
\text { Content } \\
\text { Knowledge) } \\
\text { before and it is a } \\
\text { familiar idea to } \\
\text { me. }\end{array}$ & $1.72 \%$ & 1 & $13.79 \%$ & 8 & $8.62 \%$ & 5 & $41.38 \%$ & 24 & $34.48 \%$ & 20 & 58 \\
\hline 2 & $\begin{array}{r}\text { I can select } \\
\text { effective teaching } \\
\text { approaches to } \\
\text { guide student } \\
\text { thinking and } \\
\text { learning in my } \\
\text { content area. }\end{array}$ & $0.00 \%$ & 0 & $0.00 \%$ & 0 & $1.72 \%$ & 1 & $65.52 \%$ & 38 & $32.76 \%$ & 19 & 58 \\
\hline 3 & $\begin{array}{r}\text { I can select } \\
\text { effective teaching } \\
\text { approaches to } \\
\text { guide student } \\
\text { thinking and } \\
\text { learning in } \\
\text { literacy. }\end{array}$ & $0.00 \%$ & 0 & $1.72 \%$ & 1 & $8.62 \%$ & 5 & $65.52 \%$ & 38 & $24.14 \%$ & 14 & 58 \\
\hline 4 & $\begin{array}{r}\text { I can develop and } \\
\text { use a variety of } \\
\text { assessments to } \\
\text { determine my } \\
\text { students' } \\
\text { understandings of } \\
\text { content. }\end{array}$ & $0.00 \%$ & 0 & $0.00 \%$ & 0 & $6.90 \%$ & 4 & $62.07 \%$ & 36 & $31.03 \%$ & 18 & 58 \\
\hline
\end{tabular}


In Figure 4.5, the Technological Content Knowledge beliefs of the students are presented. According to Mishra and Koehler (2006), Technological Content Knowledge (TCK) is an understanding of the impact of technology on teaching practices and knowledge within a content area. This includes the manner in which technology and content influence and constrain each other as well as how the subject matter can be changed by the use of different technologies (Mishra \& Koehler, 2006). The majority of the students believed they had high TCK; however, the results also indicated that many students did not believe they had this form of knowledge.

\section{Figure 4.5. Technological Content Knowledge}

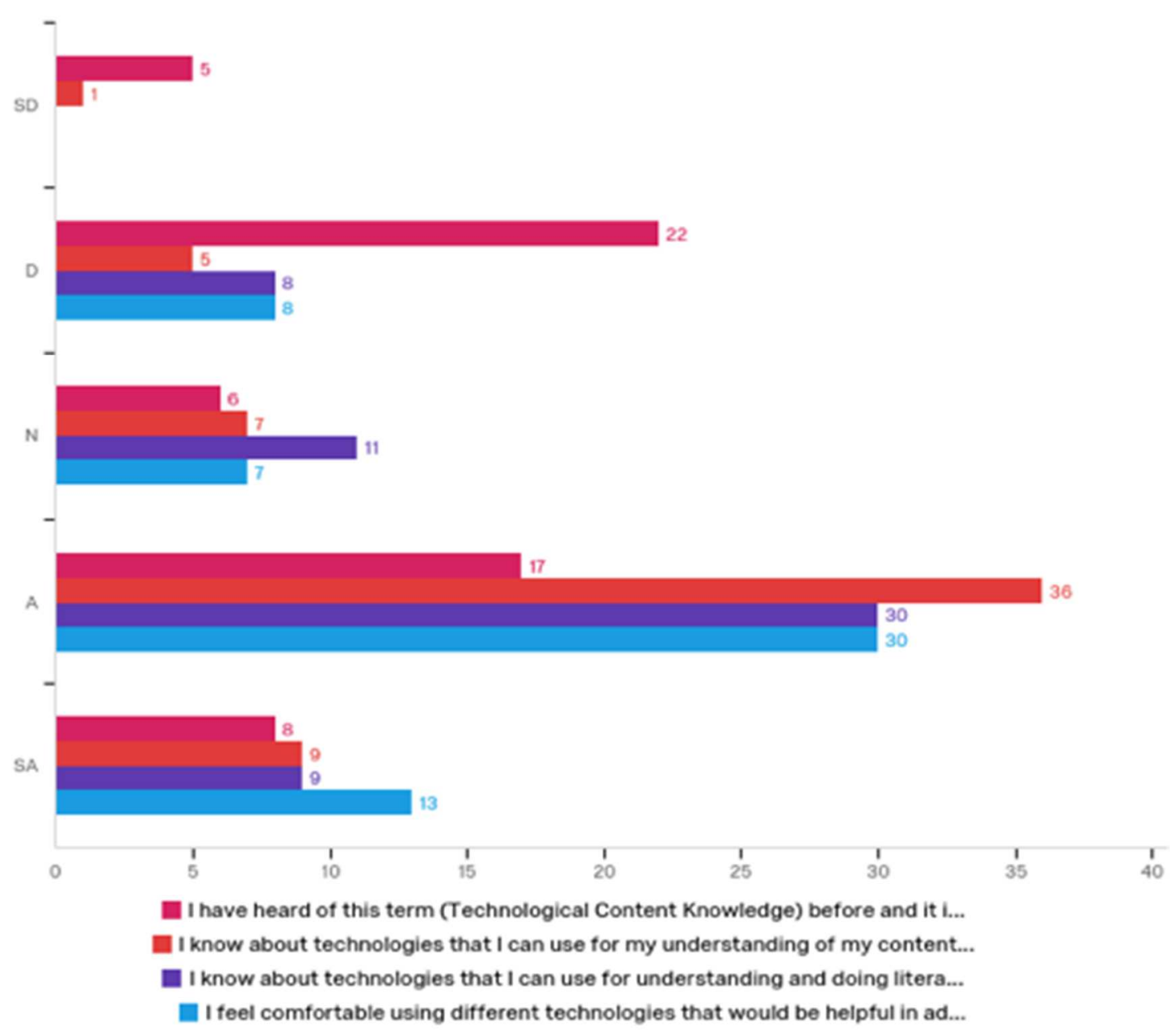




\begin{tabular}{|c|c|c|c|c|c|c|c|}
\hline \# & Field & Minimum & Maximum & Mean & $\begin{array}{c}\text { Std } \\
\text { Deviation }\end{array}$ & Variance & Count \\
\hline 1 & $\begin{array}{l}\text { I have heard of this } \\
\text { term (Technological } \\
\text { Content Knowledge) } \\
\text { before and it is a } \\
\text { familiar idea to me. }\end{array}$ & 1.00 & 5.00 & 3.02 & 1.25 & 1.57 & 58 \\
\hline 2 & $\begin{array}{r}\text { I know about } \\
\text { technologies that I can } \\
\text { use for my } \\
\text { understanding of my } \\
\text { content area. }\end{array}$ & 1.00 & 5.00 & 3.81 & 0.86 & 0.74 & 58 \\
\hline 3 & $\begin{array}{l}\text { I know about } \\
\text { technologies that I can } \\
\text { use for understanding } \\
\text { and doing literacy. }\end{array}$ & 2.00 & 5.00 & 3.69 & 0.89 & 0.80 & 58 \\
\hline 4 & $\begin{array}{r}\text { I feel comfortable } \\
\text { using different } \\
\text { technologies that } \\
\text { would be helpful in } \\
\text { advancing my } \\
\text { students' } \\
\text { understanding of the } \\
\text { content. }\end{array}$ & 2.00 & 5.00 & 3.83 & 0.93 & 0.87 & 58 \\
\hline
\end{tabular}




\begin{tabular}{|c|c|c|c|c|c|c|c|c|c|c|c|c|}
\hline \# & Question & SD & & D & & $\mathbf{N}$ & & $\mathbf{A}$ & & $\mathbf{S A}$ & & Total \\
\hline 1 & $\begin{array}{r}\text { I have heard of } \\
\text { this term } \\
\text { (Technologica } \\
1 \text { Content } \\
\text { Knowledge) } \\
\text { before and it is } \\
\text { a familiar idea } \\
\text { to me. }\end{array}$ & $\begin{array}{r}8.62 \\
\%\end{array}$ & 5 & $\begin{array}{r}37.93 \\
\%\end{array}$ & $\begin{array}{l}2 \\
2\end{array}$ & $\begin{array}{r}10.34 \\
\%\end{array}$ & 6 & $\begin{array}{r}29.31 \\
\%\end{array}$ & $\begin{array}{l}1 \\
7\end{array}$ & $\begin{array}{r}13.79 \\
\%\end{array}$ & 8 & 58 \\
\hline 2 & $\begin{array}{r}\text { I know about } \\
\text { technologies } \\
\text { that I can use } \\
\text { for my } \\
\text { understanding } \\
\text { of my content } \\
\text { area. }\end{array}$ & $\begin{array}{r}1.72 \\
\%\end{array}$ & 1 & $8.62 \%$ & 5 & $\begin{array}{r}12.07 \\
\%\end{array}$ & 7 & $\begin{array}{r}62.07 \\
\%\end{array}$ & $\begin{array}{l}3 \\
6\end{array}$ & $\begin{array}{r}15.52 \\
\%\end{array}$ & 9 & 58 \\
\hline 3 & $\begin{array}{r}\text { I know about } \\
\text { technologies } \\
\text { that I can use } \\
\text { for } \\
\text { understanding } \\
\text { and doing } \\
\text { literacy. }\end{array}$ & $\begin{array}{r}0.00 \\
\%\end{array}$ & 0 & $\begin{array}{r}13.79 \\
\%\end{array}$ & 8 & $\begin{array}{r}18.97 \\
\%\end{array}$ & $\begin{array}{l}1 \\
1\end{array}$ & $\begin{array}{r}51.72 \\
\%\end{array}$ & $\begin{array}{l}3 \\
0\end{array}$ & $\begin{array}{r}15.52 \\
\%\end{array}$ & 9 & 58 \\
\hline 4 & $\begin{array}{l}\text { I feel } \\
\text { comfortable } \\
\text { using different } \\
\text { technologies } \\
\text { that would be } \\
\text { helpful in } \\
\text { advancing my } \\
\text { students' } \\
\text { understanding } \\
\text { of the content. }\end{array}$ & $\begin{array}{r}0.00 \\
\%\end{array}$ & 0 & $\begin{array}{r}13.79 \\
\%\end{array}$ & 8 & $\begin{array}{r}12.07 \\
\%\end{array}$ & 7 & $\begin{array}{r}51.72 \\
\%\end{array}$ & $\begin{array}{l}3 \\
0\end{array}$ & $\begin{array}{r}22.41 \\
\%\end{array}$ & $\begin{array}{l}1 \\
3\end{array}$ & 58 \\
\hline
\end{tabular}

According to Mishra and Koehler (2006), Technological Pedagogical Knowledge (TPK) is an understanding of how teaching and learning may change when certain technologies are used 
in certain ways. This includes knowing the pedagogical affordances and constraints of a variety of technological tools related to disciplinary and developmentally appropriate pedagogical designs and strategies (Mishra \& Koehler, 2006). As shown in Figure 4.6, overall, the students felt confident about having this form of knowledge.

\section{Figure 4.6. Technological Pedagogical Knowledge}

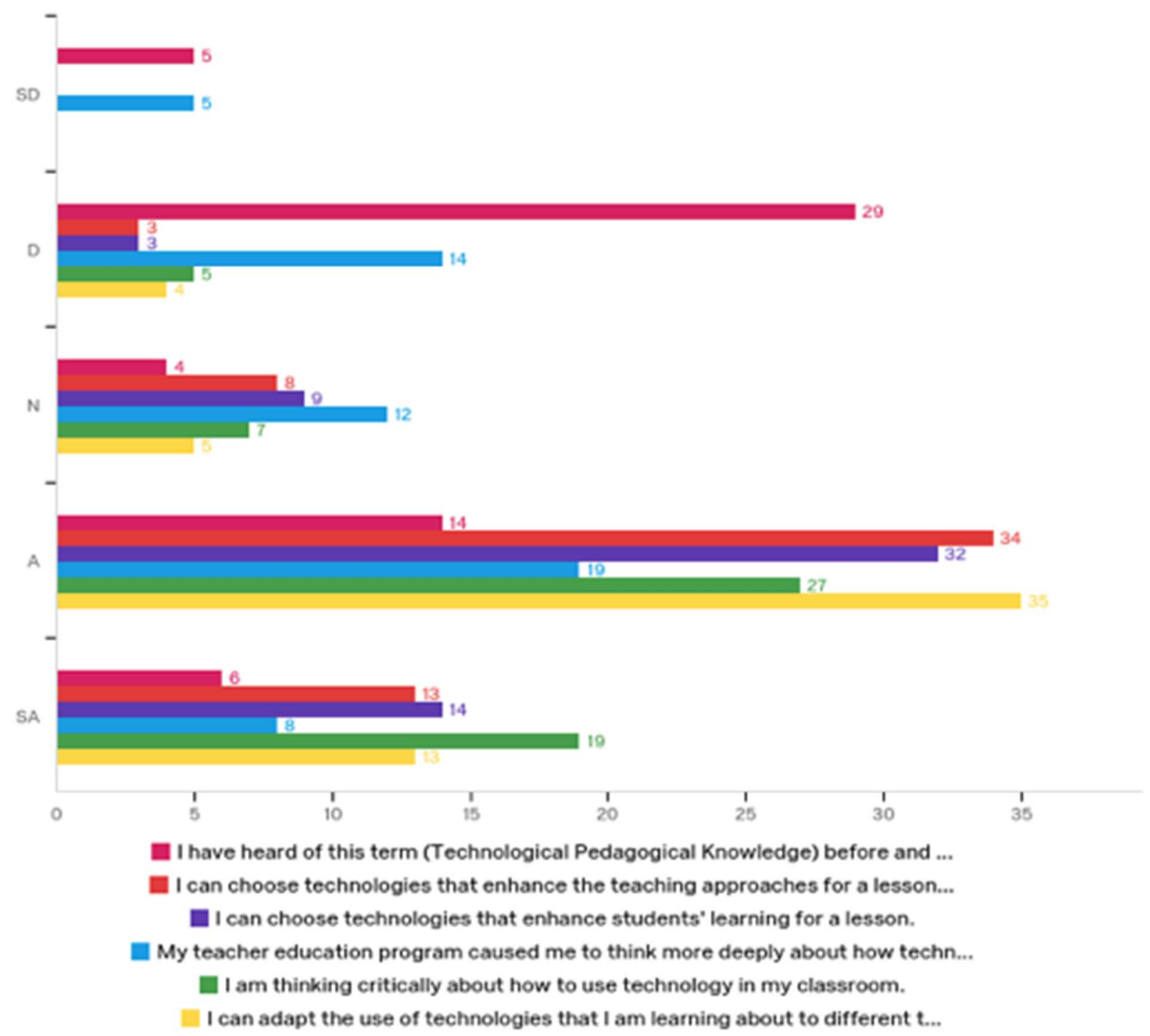




\begin{tabular}{|c|c|c|c|c|c|c|c|}
\hline \# & Field & Minimum & Maximum & Mean & $\begin{array}{c}\text { Std } \\
\text { Deviation }\end{array}$ & Variance & Count \\
\hline 2 & $\begin{array}{r}\text { I can choose } \\
\text { technologies that } \\
\text { enhance the teaching } \\
\text { approaches for a } \\
\text { lesson. }\end{array}$ & 2.00 & 5.00 & 3.98 & 0.75 & 0.57 & 58 \\
\hline 3 & $\begin{array}{r}\text { I can choose } \\
\text { technologies that } \\
\text { enhance students' } \\
\text { learning for a lesson. }\end{array}$ & 2.00 & 5.00 & 3.98 & 0.78 & 0.60 & 58 \\
\hline 4 & $\begin{array}{l}\text { My teacher education } \\
\text { program caused me to } \\
\text { think more deeply } \\
\text { about how technology } \\
\text { could influence the } \\
\text { teaching approaches I } \\
\text { use in my classroom. }\end{array}$ & 1.00 & 5.00 & 3.19 & 1.20 & 1.43 & 58 \\
\hline 5 & $\begin{array}{r}\text { I am thinking critically } \\
\text { about how to use } \\
\text { technology in my } \\
\text { classroom. }\end{array}$ & 2.00 & 5.00 & 4.03 & 0.89 & 0.79 & 58 \\
\hline 6 & $\begin{array}{r}\text { I can adapt the use of } \\
\text { technologies that I am } \\
\text { learning about to } \\
\text { different teaching } \\
\text { activities. }\end{array}$ & 2.00 & 5.00 & 4.00 & 0.77 & 0.60 & 57 \\
\hline
\end{tabular}




\begin{tabular}{|c|c|c|c|c|c|c|c|c|c|c|c|c|}
\hline \# & Question & SD & & D & & $\mathbf{N}$ & & $\mathbf{A}$ & & $\mathbf{S A}$ & & Tota \\
\hline 1 & $\begin{array}{l}\text { I have heard } \\
\text { of this term } \\
\text { (Technologica } \\
\text { 1 Pedagogical } \\
\text { Knowledge) } \\
\text { before and it } \\
\text { is a familiar } \\
\text { idea to me. }\end{array}$ & $\begin{array}{r}8.62 \\
\%\end{array}$ & 5 & $\begin{array}{r}50.00 \\
\%\end{array}$ & $\begin{array}{l}2 \\
9\end{array}$ & $6.90 \%$ & 4 & $\begin{array}{r}24.14 \\
\%\end{array}$ & $\begin{array}{l}1 \\
4\end{array}$ & $\begin{array}{r}10.34 \\
\%\end{array}$ & 6 & 58 \\
\hline 2 & $\begin{array}{l}\text { I can choose } \\
\text { technologies } \\
\text { that enhance } \\
\text { the teaching } \\
\text { approaches } \\
\text { for a lesson. }\end{array}$ & $\begin{array}{r}0.00 \\
\%\end{array}$ & 0 & $5.17 \%$ & 3 & $\begin{array}{r}13.79 \\
\%\end{array}$ & 8 & $\begin{array}{r}58.62 \\
\%\end{array}$ & $\begin{array}{l}3 \\
4\end{array}$ & $\begin{array}{r}22.41 \\
\%\end{array}$ & $\begin{array}{l}1 \\
3\end{array}$ & 58 \\
\hline 3 & $\begin{array}{l}\text { I can choose } \\
\text { technologies } \\
\text { that enhance } \\
\text { students' } \\
\text { learning for a } \\
\text { lesson. }\end{array}$ & $\begin{array}{r}0.00 \\
\%\end{array}$ & 0 & $5.17 \%$ & 3 & $\begin{array}{r}15.52 \\
\%\end{array}$ & 9 & $\begin{array}{r}55.17 \\
\%\end{array}$ & $\begin{array}{l}3 \\
2\end{array}$ & $\begin{array}{r}24.14 \\
\%\end{array}$ & $\begin{array}{l}1 \\
4\end{array}$ & 58 \\
\hline 4 & $\begin{array}{l}\text { My teacher } \\
\text { education } \\
\text { program } \\
\text { caused me to } \\
\text { think more } \\
\text { deeply about } \\
\text { how } \\
\text { technology } \\
\text { could } \\
\text { influence the } \\
\text { teaching } \\
\text { approaches I } \\
\text { use in my } \\
\text { classroom. }\end{array}$ & $\begin{array}{r}8.62 \\
\%\end{array}$ & 5 & $\begin{array}{r}24.14 \\
\%\end{array}$ & $\begin{array}{l}1 \\
4\end{array}$ & $\begin{array}{r}20.69 \\
\%\end{array}$ & $\begin{array}{l}1 \\
2\end{array}$ & $\begin{array}{r}32.76 \\
\%\end{array}$ & $\begin{array}{l}1 \\
9\end{array}$ & $\begin{array}{r}13.79 \\
\%\end{array}$ & 8 & 58 \\
\hline 5 & $\begin{array}{l}\text { I am thinking } \\
\text { critically } \\
\text { about how to } \\
\text { use } \\
\text { technology in } \\
\text { my classroom. }\end{array}$ & $\begin{array}{r}0.00 \\
\%\end{array}$ & 0 & $8.62 \%$ & 5 & $\begin{array}{r}12.07 \\
\%\end{array}$ & 7 & $\begin{array}{r}46.55 \\
\%\end{array}$ & $\begin{array}{l}2 \\
7\end{array}$ & $\begin{array}{r}32.76 \\
\%\end{array}$ & $\begin{array}{l}1 \\
9\end{array}$ & 58 \\
\hline
\end{tabular}




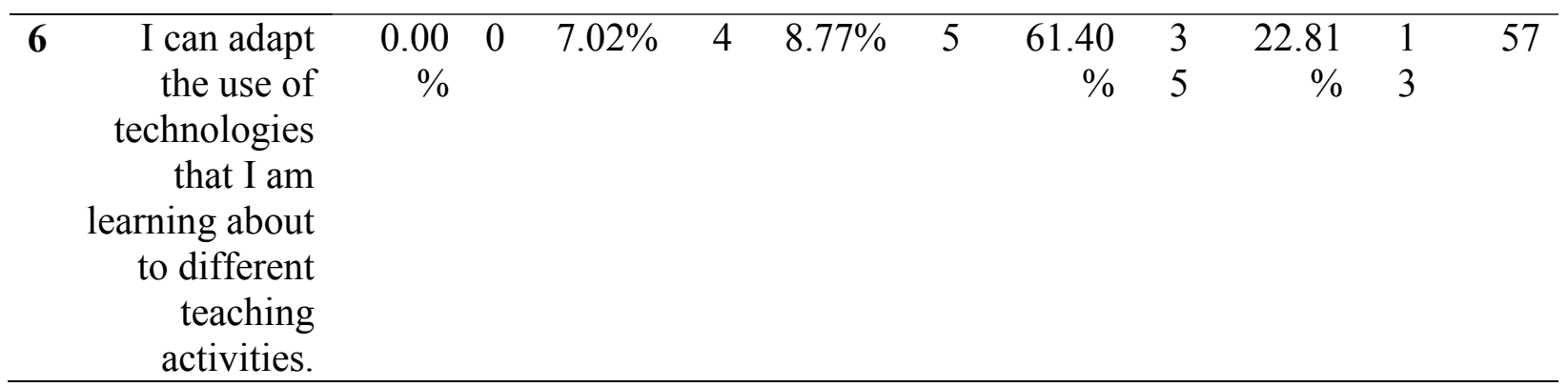

Mishra and Koehler (2006) explained that Technology Pedagogical Content Knowledge (TPACK) is an understanding that comes from interactions among content, pedagogy, and technology knowledge. They stated that it is

the basis of effective teaching with technology, requiring an understanding of the representation of concepts using technologies; pedagogical techniques that use technologies in constructive ways to teach content; knowledge of what makes concepts difficult or easy to learn and how technology can help redress some of the problems that students face; knowledge of students' prior knowledge and theories of epistemology; and knowledge of how technologies can be used to build on existing knowledge to develop new epistemologies or strengthen old ones.” (Mishra \& Koehler, 2006, p. 1028)

The results and statistics for these questions are represented in Figure 4.7 below. 


\section{Figure 4.7. Technological Pedagogical Content Knowledge}

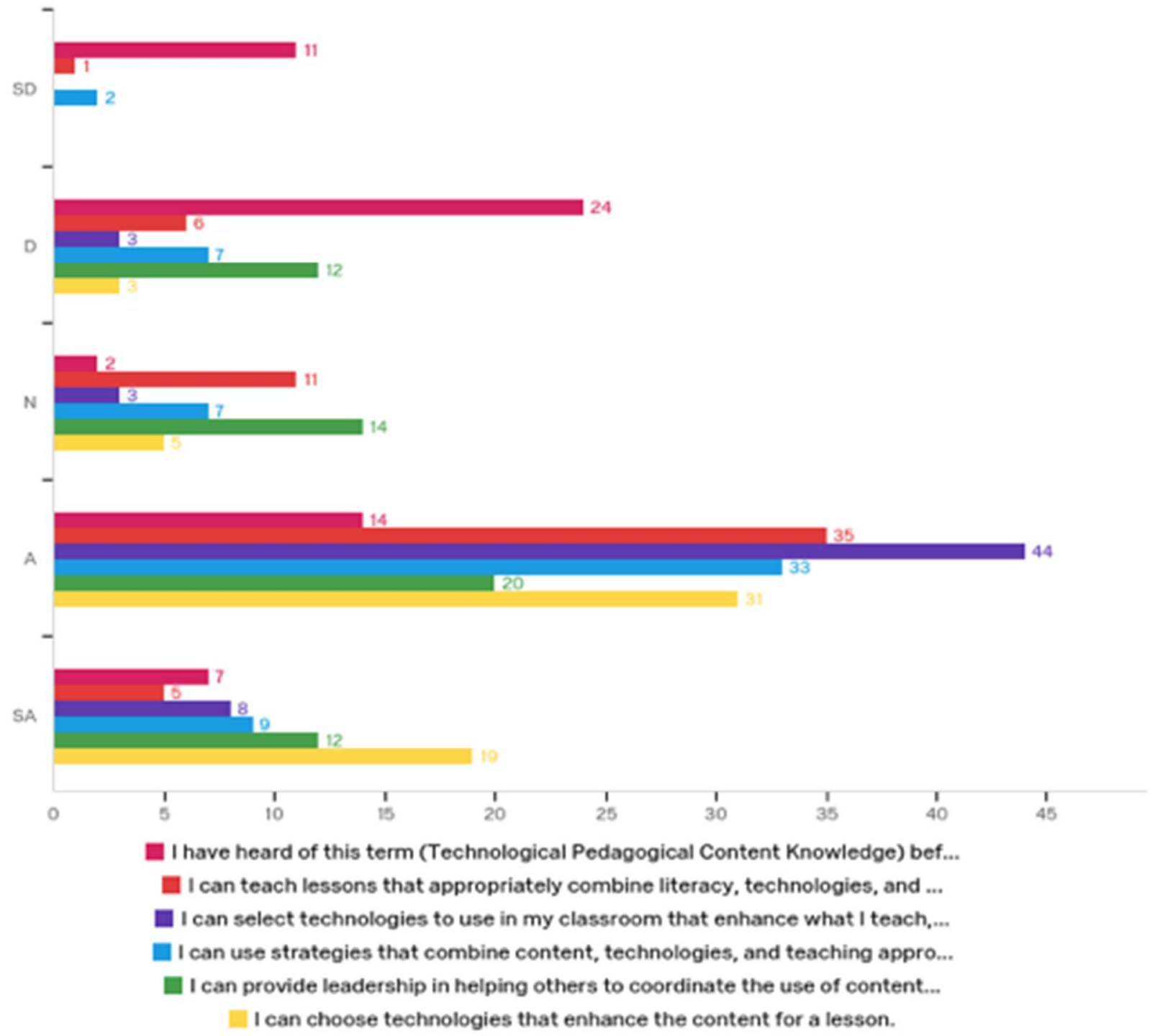




\begin{tabular}{|c|c|c|c|c|c|c|c|}
\hline \# & Field & Minimum & Maximum & Mean & $\begin{array}{c}\text { Std } \\
\text { Deviation }\end{array}$ & Variance & Count \\
\hline 1 & $\begin{array}{l}\text { I have heard of this term } \\
\text { (Technological } \\
\text { Pedagogical Content } \\
\text { Knowledge) before and } \\
\text { it is a familiar idea to } \\
\text { me. }\end{array}$ & 1.00 & 5.00 & 2.69 & 1.34 & 1.80 & 58 \\
\hline 2 & $\begin{array}{l}\text { I can teach lessons that } \\
\text { appropriately combine } \\
\text { literacy, technologies, } \\
\text { and teaching } \\
\text { approaches. }\end{array}$ & 1.00 & 5.00 & 3.64 & 0.84 & 0.71 & 58 \\
\hline 3 & $\begin{array}{l}\text { I can select technologies } \\
\text { to use in my classroom } \\
\text { that enhance what I } \\
\text { teach, how I teach, and } \\
\text { what students learn. }\end{array}$ & 2.00 & 5.00 & 3.98 & 0.63 & 0.40 & 58 \\
\hline 4 & $\begin{array}{l}\text { I can use strategies that } \\
\text { combine content, } \\
\text { technologies, and } \\
\text { teaching approaches } \\
\text { that I learned about in } \\
\text { my coursework in my } \\
\text { classroom. }\end{array}$ & 1.00 & 5.00 & 3.69 & 0.99 & 0.97 & 58 \\
\hline 5 & $\begin{array}{l}\text { I can provide leadership } \\
\text { in helping others to } \\
\text { coordinate the use of } \\
\text { content, technologies, } \\
\text { and teaching approaches } \\
\text { at my school and/or } \\
\text { district. }\end{array}$ & 2.00 & 5.00 & 3.55 & 1.04 & 1.07 & 58 \\
\hline 6 & $\begin{array}{l}\text { I can choose } \\
\text { technologies that } \\
\text { enhance the content for } \\
\text { a lesson. }\end{array}$ & 2.00 & 5.00 & 4.14 & 0.78 & 0.60 & 58 \\
\hline
\end{tabular}




\begin{tabular}{|c|c|c|c|c|c|c|c|c|c|c|c|c|}
\hline \# & Question & SD & & D & & $\mathbf{N}$ & & $\mathbf{A}$ & & SA & & $\mathbf{T}$ \\
\hline 1 & $\begin{array}{l}\text { I have heard } \\
\text { of this term } \\
\text { (Technologic } \\
\text { al } \\
\text { Pedagogical } \\
\text { Content } \\
\text { Knowledge) } \\
\text { before and it } \\
\text { is a familiar } \\
\text { idea to me. }\end{array}$ & $18.9 \%$ & 11 & $41.38 \%$ & 24 & $3.45 \%$ & 2 & $24.14 \%$ & 14 & $12.07 \%$ & 7 & $\begin{array}{l}5 \\
8\end{array}$ \\
\hline 2 & $\begin{array}{l}\text { I can teach } \\
\text { lessons that } \\
\text { appropriately } \\
\text { combine } \\
\text { literacy, } \\
\text { technologies, } \\
\text { and teaching } \\
\text { approaches. }\end{array}$ & $1.72 \%$ & 1 & $10.34 \%$ & 6 & $\begin{array}{r}18.97 \\
\%\end{array}$ & $\begin{array}{l}1 \\
1\end{array}$ & $60.34 \%$ & 35 & $8.62 \%$ & 5 & $\begin{array}{l}5 \\
8\end{array}$ \\
\hline 3 & $\begin{array}{l}\text { I can select } \\
\text { technologies } \\
\text { to use in my } \\
\text { classroom } \\
\text { that enhance } \\
\text { what I teach, } \\
\text { how I teach, } \\
\text { and what } \\
\text { students } \\
\text { learn. }\end{array}$ & $0.00 \%$ & 0 & $5.17 \%$ & 3 & $5.17 \%$ & 3 & $75.86 \%$ & 44 & $13.79 \%$ & 8 & $\begin{array}{l}5 \\
8\end{array}$ \\
\hline 4 & $\begin{array}{l}\text { I can use } \\
\text { strategies that } \\
\text { combine } \\
\text { content, } \\
\text { technologies, } \\
\text { and teaching } \\
\text { approaches } \\
\text { that I learned } \\
\text { about in my } \\
\text { coursework } \\
\text { in my } \\
\text { classroom. }\end{array}$ & $3.45 \%$ & 2 & $12.07 \%$ & 7 & $\begin{array}{r}12.07 \\
\%\end{array}$ & 7 & $56.90 \%$ & 33 & $15.52 \%$ & 9 & $\begin{array}{l}5 \\
8\end{array}$ \\
\hline
\end{tabular}




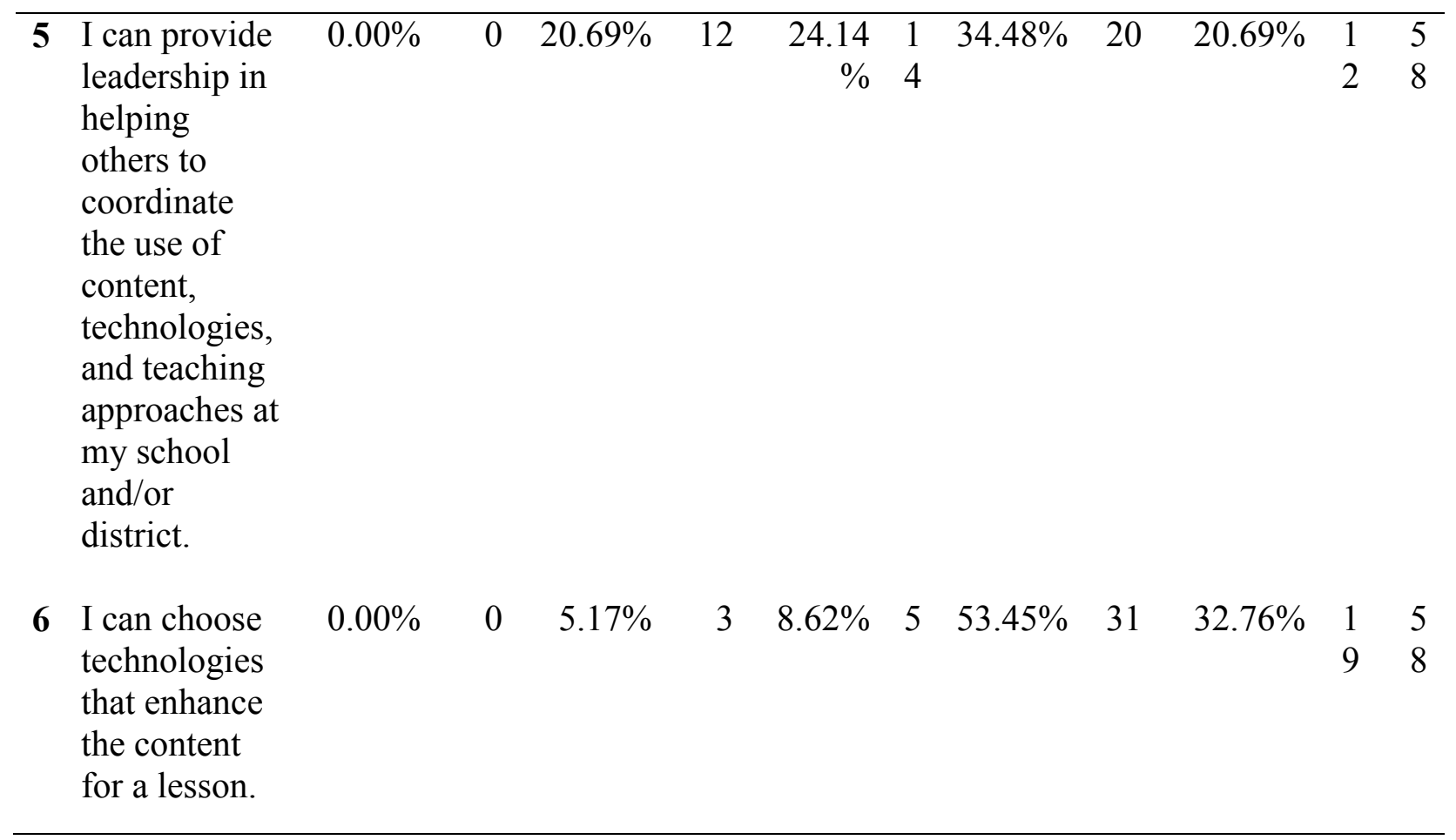

The final knowledge domain is represented in Figure 4.8 below. Critical Technological Pedagogical Content Knowledge (C-TPACK) includes knowledge directly related to Digital Literacies and Critical Digital Literacies. Digital literacies have been defined as the participatory and collaborative practices and the engagement in meaning-making through the use of texts that are created, distributed, and exchanged through digital technologies (Lankshear \& Knobel, 2008). Critical Digital Literacies (CDL) include the understanding that CDL extends beyond the development of a specific set of technological tools. CDL reflects the ability to develop knowledge and represent oneself; understand, navigate, and create within the social structure of the digital environment; and recognize the positions of power at work in that environment and how that power structure impacts each individual. This includes the decoding, encoding, interrogation, and meaning-making with texts found in digital environments (Avila \& Pandya, 2013). As a result, students engage in opportunities to critically reflect on their cultural worlds, 
develop understandings of other cultures, and develop and represent their own cultures and identities using digital tools (Avila \& Pandya, 2013).

\section{Figure 4.8. Critical Technological Pedagogical Content Knowledge (C-TPACK)}

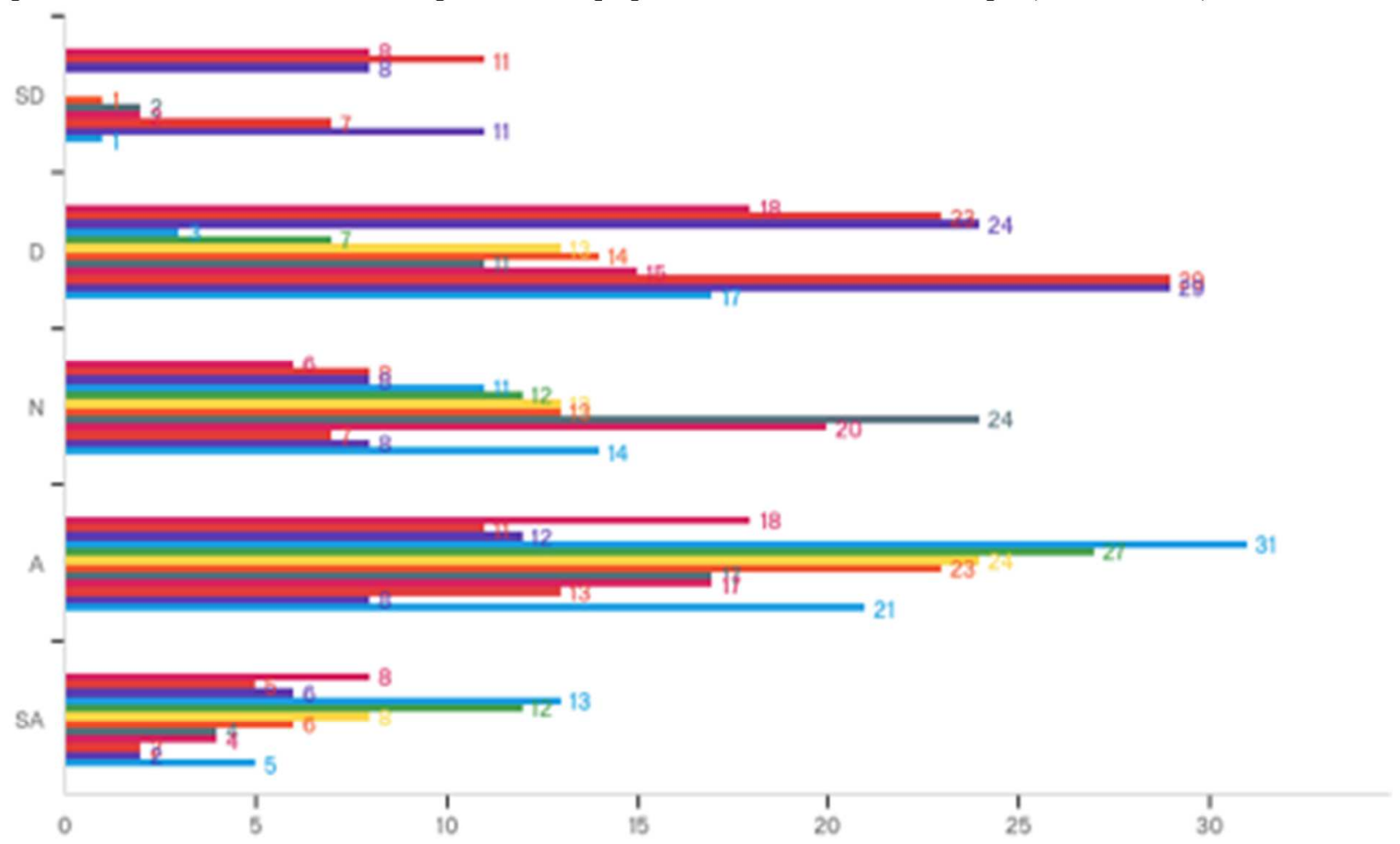

I learned about digital literacies in my teacher education program.

I learned about critical digital literacies in my teacher education program...

I experienced critical digital literacy practices as modeled by my instruct...

I believe that critical digital literacies have value in teaching my conten...

My knowledge of critical digital literacies can help me develop my understa...

I am able to apply critical theory to technologies.

I understand how to integrate technology and critical digital literacy into...

D I can utilize critical digital literacies to become familiar with common st...

I am confident about employing critical theory in combination with technolo...

I utilized critical digital literacies in my lesson planning during my teac...

I utilized critical digital literacies while teaching during my clinicals.

I continually plan to incorporate critical digital literacies practices int... 


\begin{tabular}{|c|c|c|c|c|c|c|c|}
\hline$\#$ & Field & Minimum & Maximum & Mean & $\begin{array}{c}\text { Std } \\
\text { Deviation }\end{array}$ & Variance & Count \\
\hline 1 & $\begin{array}{l}\text { I learned about } \\
\text { digital literacies in } \\
\text { my teacher } \\
\text { education program. }\end{array}$ & 1.00 & 5.00 & 3.00 & 1.31 & 1.72 & 58 \\
\hline 2 & $\begin{array}{l}\text { I learned about } \\
\text { critical digital } \\
\text { literacies in my } \\
\text { teacher education } \\
\text { program. }\end{array}$ & 1.00 & 5.00 & 2.59 & 1.23 & 1.52 & 58 \\
\hline 3 & $\begin{array}{l}\text { I experienced critical } \\
\text { digital literacy } \\
\text { practices as modeled } \\
\text { by my instructors. }\end{array}$ & 1.00 & 5.00 & 2.72 & 1.23 & 1.51 & 58 \\
\hline 4 & $\begin{array}{l}\text { I believe that critical } \\
\text { digital literacies } \\
\text { have value in } \\
\text { teaching my content } \\
\text { area. }\end{array}$ & 2.00 & 5.00 & 3.93 & 0.78 & 0.62 & 58 \\
\hline 5 & $\begin{array}{l}\text { My knowledge of } \\
\text { critical digital } \\
\text { literacies can help } \\
\text { me develop my } \\
\text { understanding of my } \\
\text { content area. }\end{array}$ & 2.00 & 5.00 & 3.76 & 0.92 & 0.84 & 58 \\
\hline 6 & $\begin{array}{l}\text { I am able to apply } \\
\text { critical theory to } \\
\text { technologies. }\end{array}$ & 2.00 & 5.00 & 3.47 & 0.99 & 0.97 & 58 \\
\hline 7 & $\begin{array}{l}\text { I understand how to } \\
\text { integrate technology } \\
\text { and critical digital } \\
\text { literacy into my } \\
\text { lesson planning and } \\
\text { instruction. }\end{array}$ & 1.00 & 5.00 & 3.33 & 1.01 & 1.03 & 57 \\
\hline
\end{tabular}




\begin{tabular}{|c|c|c|c|c|c|c|c|}
\hline 8 & $\begin{array}{l}\text { I can utilize critical } \\
\text { digital literacies to } \\
\text { become familiar } \\
\text { with common } \\
\text { student } \\
\text { understanding and } \\
\text { misconceptions. }\end{array}$ & 1.00 & 5.00 & 3.17 & 0.93 & 0.87 & 58 \\
\hline 9 & $\begin{array}{l}\text { I am confident about } \\
\text { employing critical } \\
\text { theory in } \\
\text { combination with } \\
\text { technologies to help } \\
\text { me understand and } \\
\text { do literacy. }\end{array}$ & 1.00 & 5.00 & 3.10 & 0.98 & 0.95 & 58 \\
\hline 10 & $\begin{array}{l}\text { I utilized critical } \\
\text { digital literacies in } \\
\text { my lesson planning } \\
\text { during my teacher } \\
\text { education program. }\end{array}$ & 1.00 & 5.00 & 2.55 & 1.07 & 1.14 & 58 \\
\hline 11 & $\begin{array}{l}\text { I utilized critical } \\
\text { digital literacies } \\
\text { while teaching } \\
\text { during my clinicals. }\end{array}$ & 1.00 & 5.00 & 2.33 & 1.04 & 1.08 & 58 \\
\hline 12 & $\begin{array}{l}\text { I continually plan to } \\
\text { incorporate critical } \\
\text { digital literacies } \\
\text { practices into my } \\
\text { lesson planning and } \\
\text { instruction. }\end{array}$ & 1.00 & 5.00 & 3.21 & 1.01 & 1.03 & 58 \\
\hline
\end{tabular}




\begin{tabular}{|c|c|c|c|c|c|c|c|c|c|c|c|c|}
\hline \# & Question & SD & & D & & $\mathbf{N}$ & & $\mathbf{A}$ & & $\mathbf{S A}$ & & $\begin{array}{l}\text { To } \\
\text { tal }\end{array}$ \\
\hline 1 & $\begin{array}{l}\text { I learned about } \\
\text { digital literacies } \\
\text { in my teacher } \\
\text { education } \\
\text { program. }\end{array}$ & $\begin{array}{r}13.79 \\
\%\end{array}$ & 8 & $\begin{array}{r}31.03 \\
\%\end{array}$ & 18 & $10.34 \%$ & 6 & $\begin{array}{r}31.03 \\
\%\end{array}$ & 18 & $\begin{array}{l}13.79 \\
\%\end{array}$ & 8 & 58 \\
\hline 2 & $\begin{array}{l}\text { I learned about } \\
\text { critical digital } \\
\text { literacies in my } \\
\text { teacher } \\
\text { education } \\
\text { program. }\end{array}$ & $\begin{array}{r}18.97 \\
\%\end{array}$ & 11 & $\begin{array}{r}39.66 \\
\%\end{array}$ & 23 & $13.79 \%$ & 8 & $\begin{array}{r}18.97 \\
\%\end{array}$ & 11 & $8.62 \%$ & 5 & 58 \\
\hline 3 & $\begin{array}{l}\text { I experienced } \\
\text { critical digital } \\
\text { literacy } \\
\text { practices as } \\
\text { modeled by my } \\
\text { instructors. }\end{array}$ & $\begin{array}{r}13.79 \\
\%\end{array}$ & 8 & $\begin{array}{r}41.38 \\
\%\end{array}$ & 24 & $13.79 \%$ & 8 & $\begin{array}{r}20.69 \\
\%\end{array}$ & 12 & $\begin{array}{r}10.34 \\
\%\end{array}$ & 6 & 58 \\
\hline 4 & $\begin{array}{l}\text { I believe that } \\
\text { critical digital } \\
\text { literacies have } \\
\text { value in } \\
\text { teaching my } \\
\text { content area. }\end{array}$ & $\begin{array}{r}0.00 \\
\%\end{array}$ & 0 & $5.17 \%$ & 3 & $18.97 \%$ & 11 & $\begin{array}{r}53.45 \\
\%\end{array}$ & 31 & $\begin{array}{r}22.41 \\
\%\end{array}$ & 13 & 58 \\
\hline 5 & $\begin{array}{l}\text { My knowledge } \\
\text { of critical } \\
\text { digital literacies } \\
\text { can help me } \\
\text { develop my } \\
\text { understanding } \\
\text { of my content } \\
\text { area. }\end{array}$ & $\begin{array}{r}0.00 \\
\%\end{array}$ & 0 & $\begin{array}{r}12.07 \\
\%\end{array}$ & 7 & $20.69 \%$ & 12 & $\begin{array}{r}46.55 \\
\%\end{array}$ & 27 & $\begin{array}{r}20.69 \\
\%\end{array}$ & 12 & 58 \\
\hline 6 & $\begin{array}{l}\text { I am able to } \\
\text { apply critical } \\
\text { theory to } \\
\text { technologies. }\end{array}$ & $\begin{array}{r}0.00 \\
\%\end{array}$ & 0 & $\begin{array}{r}22.41 \\
\%\end{array}$ & 13 & $22.41 \%$ & 13 & $\begin{array}{r}41.38 \\
\%\end{array}$ & 24 & $\begin{array}{r}13.79 \\
\%\end{array}$ & 8 & 58 \\
\hline 7 & $\begin{array}{l}\text { I understand } \\
\text { how to integrate } \\
\text { technology and } \\
\text { critical digital } \\
\text { literacy into my } \\
\text { lesson planning } \\
\text { and instruction. }\end{array}$ & $\begin{array}{r}1.75 \\
\%\end{array}$ & 1 & $\begin{array}{r}24.56 \\
\%\end{array}$ & 14 & $22.81 \%$ & 13 & $\begin{array}{r}40.35 \\
\%\end{array}$ & 23 & $\begin{array}{r}10.53 \\
\%\end{array}$ & 6 & 57 \\
\hline
\end{tabular}




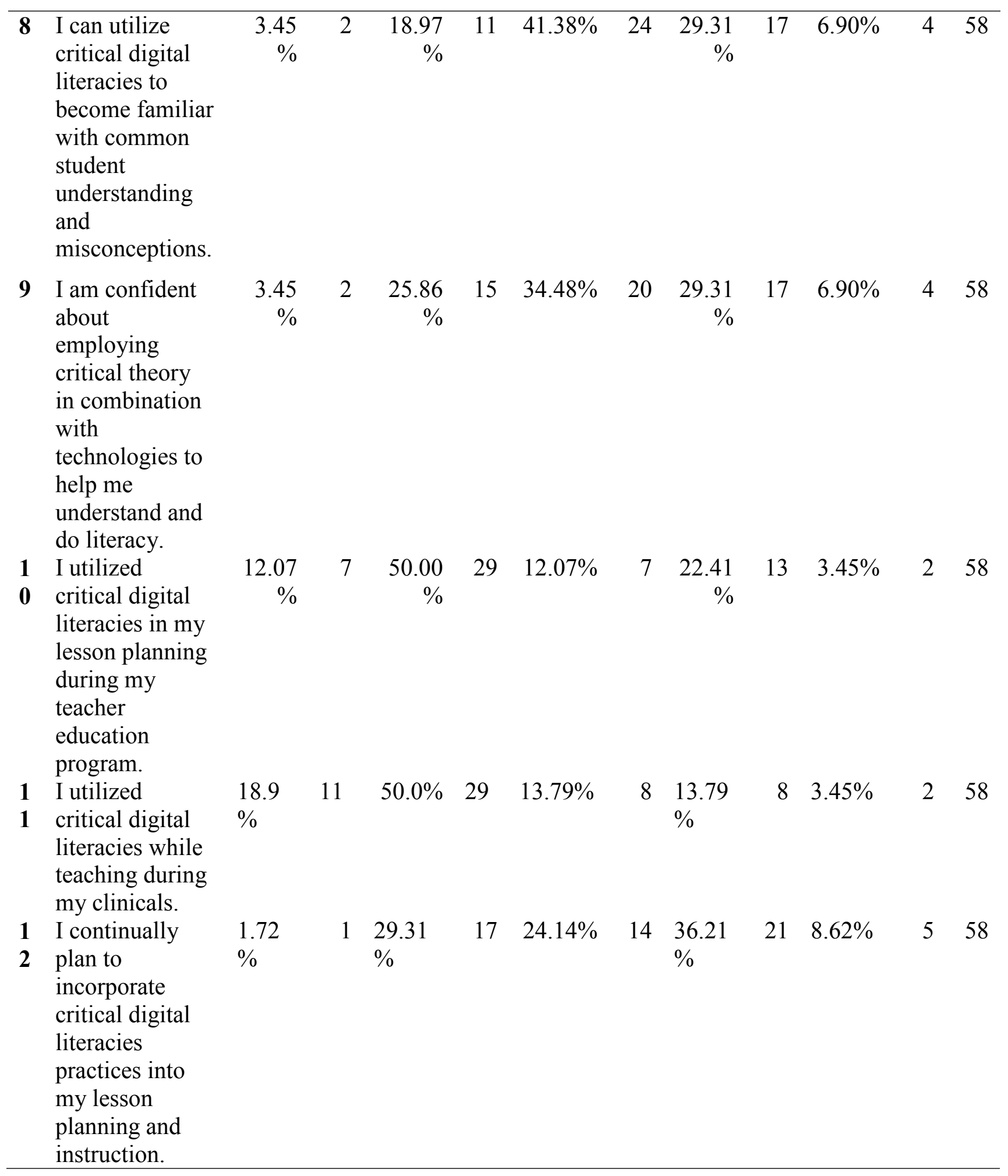




\section{Findings}

The information I gained from this survey provided a snapshot of the graduate students' beliefs about their C-TPACK. As explained in Chapters 2 and 3, this study was different from most studies that used TPACK as a predictor of teacher technology integration. While this survey produced quantitative data to initially provide me with a means to identify a subset for Phase 2 and also to provide information about students' self-indicated C-TPACK at a point in time, these findings were used in combination with other data sources providing multiple opportunities for the teachers to provide examples of, and explanations about, their processes for the recruitment of their C-TPACK. As such, I inductively moved from the quantitative data to the qualitative data, which provided a stronger and greater understanding of how different forms of knowledge (C-TPACK), teachers' practices, and teachers' perspectives worked together to provide insight about the teachers' technology integration and CDL practices.

In the figures and tables that are presented, the following abbreviations were assigned: Strongly Disagree (SD), Disagree (D), Neither (N), Agree (A), Strongly Agree (SA). To help me analyze the results, I assigned numerical values to each of the five choices of answers offered to the graduate students. The numerical values are: SD (1), D (2), N (3), A (4), and SA (5). If a student answers A or SA, I considered them to have a moderate to high knowledge, respectively, with regard to the questions. As explained in Chapter 3, the scores were calculated and those students who indicated high to very high C-TPACK knowledge were recruited to be the subset.

\section{Discussion}

This data was important for several reasons. First, the survey data was used to identify Phase 2 participants as it showed the students who believed they had moderate to high CTPACK, and also directed to me to students who were practicing teachers. According to previous 
research and studies, a high level of TPACK can lead to technology integration practices in the classroom (Graham, Borup, \& Smith, 2012; Hofer \& Grandgenett, 2012; Niess, 2011; Pamuk, 2012; Schmidt et al., 2009). Because I was interested in how practicing teachers recruited their C-TPACK in their planning and instruction, I believed it was important to learn about their beliefs in their domain knowledges first. As such, this survey offered a starting point from which to begin my analysis (Chai, Koh, \& Tsai, 2010; Koh \& Divaharan, 2011; Pamuk, 2012; Paratore, et al., 2016) and also a data source for comparative analysis within each and across the 4 participants who served as the Phase 2 subset.

\section{Phase 2 Subset of Participants}

I used descriptive statistics to identify those students who self-indicated they had a moderate to high level of C-TPACK. I also cross-checked those who self-indicated they had a moderate to high C-TPACK with those students who identified as practicing middle or high school teachers. It was important that the students be practicing teachers as I intended to collect other data related specifically to teaching practices in order to triangulate my findings. Of the 58 participants who completed surveys, 25 were practicing teachers. All 25 teachers consented to be contacted about further participation in this study (Phase 2) and all provided their names and email addresses. To determine who of the 25 teachers I invited to participate in for Phase 2, I first individually compared the likert scale survey answers to determine who self-indicated they had a high level C-TPACK. Specifically, answers to questions 18-25 were analyzed. The teachers who indicated they agreed or strongly agreed in $90 \%$ of those answers were identified as potential Phase 2 participants. This resulted in 16 potential Phase 2 participants. The findings from all data sources combined provided answers to RQ2 and RQ3. 


\section{Consideration of quantitative data in combination with qualitative data.}

The self-indicated C-TPACK data provided by the subset of participants for Phase 2 contributed to my understanding about how their beliefs about their C-TPACK may/may not have been reflected in their teaching practices. To some degree, those responses also helped guide my questions for the interview. In combination with the lesson plans, observations and interviews, the survey data helped me understand Phase 2 participants' processes for recruiting their C-TPACK in order to make decisions about technology integration and its critical dimensions. Finally, I believe the survey gave the graduate students exposure to the eight domains of knowledge that constitute C-TPACK, and that exposure could prove to be educative for the teachers (Kim, C., Kim, Lee, Spector, \& DeMeester, 2013; Ruggiero \& Mong, 2015). In fact, in the interview, when asked about CDL, one of the four teachers had heard of the term and the others had not. This lack of exposure to, and education about, C-TPACK provided a possible direction that teacher education and PD programs could explore when preparing educators to meaningfully and critically integrate technology in their practices. That direction is discussed in detail in Chapter 7.

While past TPACK surveys have largely been used to predict a teacher's technology use, that was not the purpose for my study. I believed that learning about the experiences that teachers had and the contexts in which they practiced were necessary to more deeply understand their processes for recruiting C-TPACK (Creswell, 2014). Lawless and Pellegino (2007) and Scrader and Lawless (2004) determined that relying solely on a teacher's self-assessed understanding and mastery of information more strongly reflects their confidence in working with that particular content area rather than an increase in putting that information into practice. 
This information answered RQ1: How does a subset of these graduate students who are also practicing teacher recruit their C-TPACK in their planning and instruction?

\section{CTPACK of Phase 2 Participants}

As explained above, quantitative analysis of the data from Phase 1 participants led me to 16 practicing teachers that met the criteria I established for the subset. I recruited all 16 and that recruitment process resulted in four teachers who participated in Phase 2. (See Chapter 3 for more details about the recruitment process).

Findings and Discussion for Phase 2 Participants

As mentioned in the findings for the Phase 1 Participants, Phase 2 participants were chosen based on their survey responses. Each teacher's responses are detailed below.

\section{Andrew.}

Andrew answered "agree" or "strongly agree" to a great majority of the questions in his survey. There were six exceptions: five where his answers were "disagree," and one where he responded "neither." Four of the five "disagree" responses were related to technology exposure during teacher education coursework indicating that he did not learn about or have opportunities to use CDL in teacher education coursework, and he did not experience CDL modeled by instructors. The other response that was divergent from the rest was "neither" which was in response to "I learned about digital literacies in my teacher education program." Andrew also answered "disagree" to the statement "I continually plan to incorporate critical digital literacy into my lesson planning and instruction." That answer reflected my observation of his lesson as he seemed to recruit C-TPACK for his planning, but did not in his instructional use of technology with his students. Interestingly, all of the six responses just mentioned came from the C-TPACK section of the survey and five referred to his lack of exposure to CDL. In the TPACK 
section, Andrew answered "strongly agree" to all questions. This showed that he believed the "C" in C-TPACK was missing in his teacher education and development.

\section{Kate.}

Kate answered "agree" or "strongly agree" to most of the questions. There were a few exceptions. In the CK section, she answered "neither" to "I have various ways and strategies of developing my understanding of literacy." She answered "strongly agree" to all questions in the PK, PCK sections, "agree" to all questions in the TCK section, "agree" or "strongly agree" to all questions in the TPK and TPACK sections except the questions that asked if she had heard of those terms before, to which she answered "disagree" or "strongly disagree." In the C-TPACK section, she answered "agree" or "strongly agree" to all questions with the exception of two questions where she answered "neither." Those two questions included: "I utilized critical digital literacies while teaching during my clinicals" and "I continually plan to incorporate critical digital literacy into my lesson planning and instruction." Kate's answers were not reflective of her teaching practices I observed regarding the "C" component of C-TPACK. Her interview responses also reflected a different understanding from the one provided with this survey of critical theory as applied to technology.

\section{Diane.}

Diane's responses to the survey questions were also mostly "agree" and "strongly agree." The exceptions in her responses surrounded her education coursework and her not having heard the terminology provided for her within the survey. Specifically, she had not heard of TCK, TPK, and TPACK. This showed that she was not exposed to Technology knowledge as tied to both content and pedagogy based on how those domains were defined in this survey. This

reflected what she explained in her interview about her education coursework and PD which she 
stated did not tie theory to technology practices. Also, in her interview, she explained that her self-directed PD for technology integration focused on tying content to technology. Interestingly, in her TPACK section, she responded "agree" to all questions, minus the above explained exception. Her C-TPACK section answers showed that she did not experience C-TPACK in her teacher education program, had not seen it modeled by instructors, and did not use C-TPACK in her lesson planning or clinicals in her teacher education program. She answered "neither" to five of the twelve questions in that section. Those answers provided guidance for me when developing interview questions for her to ensure I gained more detail about her understanding of CDL in teaching practices.

\section{Sara.}

Sara answered "agree" or "strongly agree" to all of her survey responses with one exception. That exception was "disagree" in response to the TPACK section question that asked if she had heard of that term. She answered "strongly agree" to all questions in the PK and PCK sections indicating her strong belief about her knowledge of how her pedagogical beliefs were recruited to her teaching practices. Her strong belief about her PCK knowledge showed that she believed she knew and practiced tying her pedagogical beliefs to her content knowledge. These findings were important as I went into my observations of Sara knowing that she believed her pedagogical beliefs were strongly influencing her practices.

\section{Concluding Thoughts}

In most all cases, the questions where these teachers replied "disagree" or "neither," were in reference to their exposure and education/teacher development surrounding those knowledge domains. The fact that those responses did not occur often showed that, overall, the teachers believed they had the knowledge I was interested in studying. Those answers also provided me 
with direction in the development of my interview questions for each teacher. Finally, as all teachers answered "agree" or "strongly agree" to most questions, I learned that I would potentially be able to see their recruitment of those knowledge domains, and in particular, the CTPACK knowledge domain which was the objective of this study. The teachers' survey responses gave me a starting point from which to compare their beliefs with their practices (as observed) and interview responses, which used in combination with the other data sources led me to a stronger understanding of how the teachers recruited their C-TPACK into their teaching practices. 


\section{CHAPTER V: QUALITATIVE ANALYSIS AND FINDINGS}

\section{Overview}

The main purpose of Phase 2 of this study was to investigate more deeply the recruitment and utilization of C-TPACK and CDL of a subset of graduate students who are also practicing teachers. This chapter provides my qualitative analysis and discussion about each of the four practicing teachers who participated in Phase 2. Specifically, the qualitative results and analyses helped me answer the following research questions:

- (RQ2) How does a subset of these graduate students who are also practicing teachers recruit their C-TPACK in their planning and instruction?

- (RQ3) What does this same subset of graduate students/practicing teachers identify as the contributing factors that supported or hindered their abilities to engage in the critical dimensions in their teaching?

\section{Findings and Discussion: Phase 2 Participants}

Below, I present each teacher who participated in Phase 2 of my study individually. I begin by providing a reminder of the results from the demographics section of the survey in Table 5.1. From there, I present each teacher independently beginning with additional background information I learned from each teacher's interview. The likert-scale survey results for each teacher were discussed in Chapter 4. Here, I present and discuss their open-ended survey answers. Moving on, I present each teacher's lesson plan, observation, and interview respectively. Each of those data source summaries are accompanied by the themes that represent my interpretation of the data. Chapter 6 provides the discussion of those interpretations where I engage in cross-case comparative analysis of the subset of teachers. 
I presented the data sources for each teacher in chronological order according to when I collected the data. Taken individually, each data source provided only a piece of the whole picture, and organizing it this way showed both what was evident and what was missing and needed further clarification from additional data. This process resulted in support for triangulation of multiple data sources as one source on its own left as many questions as answers, whereas the sources combined provided greater insights leading to deeper understanding about how each teacher recruited his/her C-TPACK in teaching practices.

My findings for each teacher resulted from constant comparative analysis of the First and Second Cycle Coding that I conducted across all data sources, which resulted in themes that worked together to guide my understanding of the teachers' practices to answer RQ2 and RQ3. In Chapter 6, I expand my discussion to include a comparative analysis of the four teachers and my understandings about how the quantitative and qualitative data worked together to provide insight and direction for future research and practice.

Table 5.1

Demographics of Phase 2 Participants

\begin{tabular}{|c|c|c|c|c|c|}
\hline Participant & Gender & Age & Content Area & $\begin{array}{l}\text { Highest } \\
\text { Degree }\end{array}$ & $\begin{array}{c}\text { Grade Level } \\
\text { Taught }\end{array}$ \\
\hline Diane & Female & 36 & Science & Doctorate & $\begin{array}{l}\text { Middle } \\
\text { School }\end{array}$ \\
\hline Kate & Female & 24 & Reading and Language Arts & $\begin{array}{l}\text { Bachelor's } \\
\text { Degree }\end{array}$ & $\begin{array}{l}\text { Middle } \\
\text { School }\end{array}$ \\
\hline Andrew & Male & 56 & $\begin{array}{l}\text { Social Science, Communications, } \\
\text { Digital Media, English }\end{array}$ & $\begin{array}{l}\text { Master's } \\
\text { Degree }\end{array}$ & High School \\
\hline Sara & Female & 46 & Spanish & $\begin{array}{l}\text { Master's } \\
\text { Degree }\end{array}$ & High School \\
\hline
\end{tabular}




\section{Diane}

At the time of my study, Diane was a teacher at a small rural middle school (grades 6 through 8). She earned her Bachelor's, Master's and Doctorate degrees in Education. When asked during the interview about educational technology courses she had taken, she stated she completed a literacy course during her graduate coursework where the professor modeled technology integration but she "wouldn't say it necessarily taught us" about technology integration. She recalled receiving exposure to different technology uses such as an LMS, digital storytelling, and "some different platforms," such as Edmodo, during that course.

The class I observed Diane teaching was 8 th grade Physics. She has been teaching 7 th and 8th grade Science for nine years, and her class sizes average 25-30 students. Previous to teaching, she worked as a naturalist at a state park and as a teacher at a planetarium. Diane believes that her diverse job experiences have strongly influenced the way she teaches Science. Those experiences have led her to teach with a "very hands-on style" where her students have opportunities to also "work with their hands and manipulate" different science objects and apply the concepts they've learned through experiential learning experiences. Diane provided me with both her lesson and unit plan during which the lesson occurred. She stated she is "hands on" and a "Constructivist," however, I did not see constructivism in her one lesson plan. As such, it was helpful to see if constructivist practices were present in the unit and in her teaching. In fact, the lesson I observed, described in detail below, was a part of a unit about Newton's Laws and came immediately after a hands-on experiment she conducted with her students.

As explained in the introduction to this chapter, each data source provided me with a

piece of the whole picture. For Diane, her survey data indicated that she believed she had a high level of C-TPACK and had incorporated CDL into her practices. This led me to analyze her 
lesson/unit plans to see what her intentions were regarding recruiting C-TPACK into her instruction. Importantly, my observation of Diane showed that the "C" in C-TPACK was not present, her technology use was substitutive, and her technology integration practices during instruction served a didactic purpose. Her interview helped me delve into her thought processes about the decisions she made and provided me with an understanding of her planning and instruction practices.

\section{Survey Results}

For the open-ended questions, Diane recalled that she took a Master's degree course in literacy that included technology integration that was tied to content. Specifically, the professor incorporated digital storytelling software. In the next question, she explained that she effectively demonstrated combining content, technologies, and teaching approaches when she used interactive quizzes with her students. In fact, in her lesson plans she stated her intention to use such a quiz, and in the lesson I observed her using interactive quiz. While this showed her recruiting TPACK, the quiz and her actions did not include engagement in the critical dimensions of an online environment. In fact, her decision to direct the students specifically to that website prevented any critical engagement outside the purpose of answering specific questions about Newton's laws.

In addition, Diane stated that she integrates technology daily in her classroom through the use of Chromebooks and an LMS. During my observations, this proved to be the case. In another answer on the open-ended survey, she could not recall a time during her teacher education program when she learned about CDL; however, she believed she does incorporate CDL in her practices. During my observations, I did note her engaging in the critical dimensions of her teaching. I expand upon that in the discussion section below. Finally, Diane did not answer the 
survey question about what she considers to be the most important thing when integrating technology; however, I did ask her that question in her interview. Her response was that she has to be able to see technology as a means of advancing the lesson and the content before she will use it. She explained that the Next Generation Science Standards (NGSS) strongly lend themselves to integrating technology, and she is trying to identify more ways to integrate technology more because those standards. While Diane's survey provided insights into her beliefs about her C-TPACK and the ways she was exposed to and feels she includes CDL, the lesson plan provided data about her intentions and planning.

\section{Lesson Plan}

When Diane and I emailed to set up this observation, she was excited about this unit and felt this lesson in particular had a lot of technology integration. The lesson that I would observe was what Diane called a "debriefing" about the project the students had just completed. As explained above, her lesson was a part of a unit about Newton's Laws and came immediately after a hands-on experiment. In that experiment, the students applied Newton's laws by designing and building containers to protect an egg from breaking while dropping it to the ground from different heights. The debriefing activities on her plan included several different components all of which were geared toward checking student understanding, repeating/reinforcing Newton's Law concepts, and using that knowledge and understanding to solve problems presented on a worksheet and again on a quiz taken via the PBS Science website (See Appendix F for Diane's lesson plan).

During the interactive quiz, the students would use the knowledge they learned about Newton's Laws to answer questions at a website. I was able to access that website to view the quiz per a link Diane provided (https://www.physicsclassroom.com/Physics- 
Interactives/Momentum-and-Collisions/Egg-Drop/Egg-Drop-Interactive). The quiz questions were interactive in that the students controlled the variables leading to different results. They needed to know and understand the physics concepts to determine which variables would lead to a solution.

Diane included the NGSS that she intended to accomplish with this lesson. Specifically, the standards included: 1) obtaining, evaluating, and communicating information and 2) analyzing and interpreting data. Within each of those two standards is a long and descriptive list of components (https://ngss.nsta.org/PracticesFull.aspx ). She also used the 5E Instructional Model as her guide when designing this unit. The 5E Instructional Model is a teaching sequence based on constructivism according to its developers who explain the model "allows students to discover the relationships among experiences. Teachers guide, question, and suggest through indirect methods" (Bybee et al., 2006, p. 4) with the goal of students applying their knowledge and experience with the concepts to new situations. They identify five stages of learning, which include: engagement, exploration, explanation, extension, and evaluation (Bybee, 2006). Directly on her lesson plan she checked the boxes that stated "Extension" and "Evaluation" (See Appendix F for her lesson plan). The following describe those stages respectively: "The purpose for the EXTEND stage is to allow students to use their new knowledge and continue to explore its implications," and "The purpose for the EVALUATION stage is for both students and teachers to determine how much learning and understanding has taken place" (Retrieved from https://nasaeclips.arc.nasa.gov/teachertoolbox/the5e ).

\section{Constructivist elements in the lesson.}

When initially coding Diane's lesson in light of the unit plan that she provided, I noted her inclusion of constructivist teaching methods in her unit. In fact, during her interview, Diane 
described her pedagogical beliefs as founded on constructivism. In her unit plan, Diane stated two primary objectives for her Newton's Law unit that reflected constructivist teaching practices. They included: "Collaborate with peers to design, build, and test their own device, and "students will apply concepts of momentum, impulse, force, and energy." For this lesson, she planned for students to complete debriefing questions (which she did not provide but alluded to) "based on their experiences throughout the device design and construction process." According to her lesson plan, it seemed that those questions were to be delivered via multiple modes: a worksheet, videos, and the interactive quiz. She intended to use a SmartBoard, Chromebooks, videos uploaded onto her LMS (which was Google Classroom), and the interactive quiz website. Her delivery of these questions became apparent when I observed this lesson and is discussed below.

\section{Role of navigator.}

The presence of technology in Diane's lesson planning was evident based on the description of the technology tools she intended to use. It was not possible to tell where her use of Google Classroom, the SmartBoard, and the Chromebooks would fall on the SAMR rubric until I observed their actual use during her lesson as she did not provide a high level of detail about each in her plans. After going online and reviewing the interactive quiz, I determined that it fell under "Augmentation" on the SAMR rubric. This means that the technology used acted as a direct substitute but included a functional improvement (Puentedura, 2006). That functional improvement was the opportunity that the interactive quiz provided for students to try plugging in different variables to learn about different results.

After looking at the Four Resources Model for Multimodal Texts to guide my evaluation of the critical dimensions within her lesson planning, it was clear that she intended her students 
to operate as Navigators, moving in and out of non-linear texts and visual images loaded onto Google Classroom. She would also be moving between her Smartboard and Chromebooks with her students and would be utilizing a website for the quiz. I was unable to tell from her lesson plan if she engaged in the more critically based literacy practices of interpreting, designing, and interrogating as there was not that level of detail in her plans. However, I was able to analyze this further during my observations and through my interview questions, which will be discussed in detail below. As such, the recruitment of her TPACK was evident in her intention to use technology to facilitate the constructivist based objectives she created that directly related to her content. However, there was not enough detailed description within her lesson planning to indicate one way or another the degree to which she engaged in the critical dimensions.

After reviewing the standards and instructional model that she cited in her lesson plan, it seemed that to meet those standards, the students would be engaging in literacy practices that place them in the roles of Navigator, Interpreter, and Designer. This does not appear align with the activities she described in her plan. My observations were necessary to determine which intentions led to actual practices.

\section{Classroom Setting and Observation}

Upon checking into the main office when I arrived to observe Diane, I asked if I would be able to access WiFi in the building. I was told it would "take a while for the tech guy to come to the school," which was required as he had to personally approve of and allow my access. In my reflection notes, I wrote that this restrictive policy could reflect the school's concern with privacy and protection issues for students and teachers. I noted to ask Diane in the interview how she felt about the school's technology policies. I also noted that the technology support person 
was not always on school premises, and that waiting for help could prove to be a barrier for technology integration.

When I first walked into the classroom, I was surprised to see the desks in rows. Diane's desk was at the front of the classroom next to the SmartBoard. At the back corner of the room, there was a cart loaded with Chromebooks. The lights remained off for the entire lesson; however there was a wall of windows in the room which provided natural light. In my reflection notes, I wrote that I assumed, based on the collaborative nature of the Physics project the students just completed leading into this lesson, that they would be grouped or at tables. The classroom set up and the WiFi situation caused me to pre-judge this lesson. I needed to set aside the feeling that I wasn't going to be observing technology integration and CDL just because I had preconceived notions of what the classroom should look like.

When the students first entered the classroom, they were provided with a worksheet at the door and told to go to their desks, place the worksheet face down, and take out a pencil. The worksheet (in Figure 5.1 below) contained a series of review questions they would answer after the videos. 


\section{Figure 5.1. Worksheet from Diane's Lesson}

\section{Newton's Laws Review}

Instructions: Identify the law that each of the following situations exemplifies.

1. A magician pulls a tablecloth out from under dishes and glasses on a table without disturbing them.

2. A person's body is thrown outward as a car rounds a curve on a highway.

3. A picture is hanging on a wall and does not move.

4. A person not wearing a seatbelt flies through a car window when someone slams on the breaks because the person's body wants to remain in continuous motion even when the car stops.

5. Pushing a child on a swing is easier than pushing an adult on the same swing, because the adult has more inertia.

6. A soccer ball accelerates more than a bowling ball when thrown with the same force.

7. A soccer player kicks a ball with their foot and their toes are left stinging.

8. A student leaves a pencil on a desk and the pencil stays in the same spot until another student picks it up.

9. Two students are in a baseball game. The first student hits a ball very hard and it has a greater acceleration than the second student who bunts the ball lightly. 
The students were directed and reminded several times to take written notes during the videos on the back side of the worksheet. Diane played a series of videos depicting Newton's Laws in real life scenarios. The videos contained both misconceptions about Newton's Laws as well as short clips with Newton's Laws correctly applied to different scenarios. She paused the videos in several places to ask if students had questions and to provide connections between the scenarios and Newton's Laws. After the videos, the students were told to individually complete the worksheet, without discussion, using the notes they took. Once finished, students were told to get their Chromebooks from the cart but not open or start them until told to do so. At this point in my observation notes, I wrote "traditionalist teaching practices? The worksheets, classroom set up, controlling Chromebook use..." I discuss this in detail below.

Once all of the students had the Chromebooks, Diane handed out another worksheet with different scenarios that provided the students with information they would be "plugging into" the website to calculate answers based on their input. In my observations, I wrote that this was another instance where she was controlling the content that would be entered into website. She then allowed them to open the Chromebooks and directed them, step by step, exactly where she wanted them to go online to find the interactive quiz. They were told to work independently on the quiz. Diane continually answered questions and offered help to students who needed guidance. The lesson ended with students finishing the quizzes and returning the Chromebooks to the cart.

\section{Constructivist and traditionalist elements in lessons.}

As explained earlier, Diane's lesson and unit plans reflected constructivist teaching practices which aligned with her interview response about her pedagogical beliefs. However, when coding my observations, I noticed that while Diane's planning reflected a constructivist 
approach, there was a noted difference in her actual instructional approach when technology was used during the lesson. It was evident from her unit plan that the non-technology activities she intended to use with her students were experiential, reflective, and critical (for example, the Egg Drop Experiment). Interestingly, her pedagogical approach to technology use for student learning during instruction reflected traditionalism (Lankshear, \& Knobel, 2008; Montrieux, Vanderlinde, Schellens, \& De Marez 2015; Montrieux, \& Schellens 2018). Diane strongly controlled her students' technology use by walking them step-by-step to the website she wanted them to use.

Restricting access has been used in schools for protection and privacy purposes. However, that restriction could hinder teachers and students from being able to develop their own CDL. Diane discussed those restrictions in the following excerpt from her interview:

Vicki: Can you to speak to what you know about the school's policies about technology and, and basically, um, how they approach technology integration as you would see it as a teacher.

Diane: Well, um, the reason for the password issue is, a few years ago or a number of years ago, the problem was that apparently at the high school level, some students got ahold of the password and so, I'm not sure exactly what happened but, and this is completely hearsay, that a, the vast majority of the student body was on the WiFi when they were not supposed to or something to that effect and it kind of changed the policy, so to speak, on when it comes to the WiFi. We do have open WiFi before and after school for students and we have some students that will actually come over and sit like on the benches outside, um, that do not have, um, WiFi access at their house and will use the WiFi usually to play games, but, you know 
The school policies were changed to ensure students were not engaging in online activities that administration did not approve of which reflects a protectionist approach to students' engagement online (boyd, 2007; Burnett \& Merchant, 2011; Kellner \& Share, 2007). That approach was also reflective of the administration's belief that students were not taking care of the Chromebooks. Diane explained:

They went one-to-one with Chromebooks when I was, um, full-time at MSU for my grad, my graduate work. So, that would've been, at least four years ago. Um, that did not work very well. Our students, for whatever reason, I don't know the whole background story, did not take very good care of the Chromebooks... we do have one Chromebook for every student. That is, that is true. But they don't get to take them home. They don't actually travel with them or anything like that. We have Chromebook carts that are stationed in certain rooms. One happens to be in my room, so I have regular access to it. And there is some discussion going back to more the true one-to-one, um, approach to having the students have Chromebooks with them at all times, but that's still in the very preliminary stages, and has not really been decided yet. But, um, that may be an option for the future. The school's policies did impact Diane's practices. However, she did not consider the restrictions to be a problem. She was matter-of-fact about the Chromebook limitations and stated it just meant she had to plan around the restrictions. Diane stated:

Well, I do know that, some of our students do not have access or internet access at home. That I know. The number, the percentage I'm not sure... But they have their Chromes, but when it comes to, you know, being able to logon like a Chromebook or something like that, I know that some of that's limited. So, I do have to plan around that. So, that's something that I know, like we have, say, for example, what, if I want to assign a web 
quest or something like that, um, the vast majority of that time is going to have to be within class time.

Researchers describe restrictive internet policies within schools as potential barriers to social media use in education and state such protection may not be necessary (boyd, 2007; Burnett \& Merchant, 2011; Kellner \& Share, 2007). Burnett and Merchant (2011) proposed that a critical media framework can provide a means of protection against things such as passive consumerism and social stereotyping or misrepresentations of people, cultures, and/or beliefs. This is seen as helping students develop a critical perspective that “...could be used to interrogate the competing discourses which surround social media use - around positive stories of participation and empowerment on one hand and more negative associations with consumerism, exploitation, fraud, safety and so forth...” (p. 44). Kellner and Share (2007) warned against what they call a "protectionist approach" to technology and social media where educators and administrators restrict student and social media use to the point that true opportunities for critical discourse and meaningful collaboration becomes unattainable. In fact, restricting texts works against the premise of multiliteracies and the inclusion of multiple avenues for literacy practices to reach all students (The New London Group, 1996).

It was evident during the lesson that technology was integral to Diane's planning and instructional practices. She used an LMS for organizational purposes and for housing their textbook and support materials. She also used technology for content delivery purposes such as the Physics videos and the interactive quiz. Diane clearly has a high personal skill level with technology use. She utilized technology in meaningful ways to prepare for this unit and lesson. Her personal technology use aligned with the "Modification" level on the SAMR rubric, where technology allows for significant task redesign (Puentedura, 2006). In this lesson and unit, 
student technology use was largely for viewing and reviewing purposes, and Diane's technology use during the lesson was didactic rather than involving students in critical engagement in online environments. Those practices fall low on the SAMR and 4 Resources models, landing at the Augmentation level.

While the technology integration for this lesson appeared to be superficial, Diane did incorporate hands-on, collaborative activities to teach her students physics concepts as evidenced by the egg-drop project in other lessons. This pointed to a discrepancy between Diane's constructivist beliefs and her recruitment of those beliefs with regard to technology use with her students. While her teaching practices when not using technology with her students appeared to be constructivist and student-centered, her teaching practices when using technology with her content reflected a teacher-centered approach more in line with behaviorism. Deng, Chai, Tsai, and Lee (2014) explained that teacher-centered practices reflect traditionalist pedagogical beliefs and "tend to emphasize discipline, subject matter, and moral standards" (p. 247). In such instances, the teacher is the supervisor and authority in charge of the learning process "serving as the expert in a highly structured learning environment" (Tondeur et al., 2017, p. 557).

In addition, while she presented her materials using the SmartBoard to access her LMS where she housed her presentation and videos, the students were the audience for her presentation. Her purpose was didactic in the sense that her intent was specifically to teach the materials, not allow the technology to be used in ways outside of her control. This is not to say that they were not constructing meaning from her presentation, only that her instructional practice centered on her use of technology products she created. This indicated that her constructivist approach regarding activities described in her unit and lesson plans differed from her actual approach to technology activities in the classroom. Instead, it aligned more closely 
with traditionalist pedagogical practices. This conflict is addressed in more detail below in the Interview section.

\section{Absence of CDL.}

Diane's reasoning behind her choice to use technology in the ways she did was not provided in the lesson plan, making it difficult to determine the roles that critical thinking and analysis played in her real-time decisions about instructional practices. This was also the case with determining whether she understood the cultural, social, and historical contexts of technology use. I analyzed her practices in light of Watulak and Kinzer's (2013) four components of CDL and the Four Resources Model for Multimodal Texts to gain stronger insight about the engagement in the critical dimensions of her technology integration. Watulak and Kinzer (2013) explained that functional skills are an important but only partial aspect of $\mathrm{CDL}$, and as stated, Diane was skilled in creating with and using multiple tools during the lesson planning and instruction. While Diane' teaching practices surrounding technology integration during her lesson did show her adeptness with a broad range of technology tools, what was not as evident was her recruitment of CDL in those instructional practices.

Diane was unsure about what CDL meant. Increasing her exposure to information about and the practical application of critical theory to technology integration practices could have led to the development of her own C-TPACK. Once developed, that knowledge could be recruited into conversations with her students about the dominant discourses and power structures represented in digital tools and online environments. This could have decreased her worry about not knowing her students' CDL which could lead to a greater comfort level with engaging the students in the transformative and critical dimensions of technology. 


\section{Interview}

I began my interview with Diane by asking her about technology integration exposure. She explained that she had limited exposure to instructors who modeled C-TPACK. Those experiences were largely tied to technology tool use and not pedagogy and content. Diane recalled one instructor in her graduate coursework who "used some different platforms;" however, those tools were used to deliver the materials for the class, and while she was exposed to them, she had not integrated those tools into her current classroom as she did not believe they were useful for her content. I asked Diane about whether she had coursework or PD in critical theory. She stated that she had one course where critical literacy was addressed:

Vicki: What do you feel was the primary takeaway from that course, if you can recall? Diane: Okay. Um, I would say that you have to be aware or kind of cognizant of the perspective of the students that are sitting in the classroom and you're providing instruction. What I mean by that is, and I have tendency to think about critical literacy, um, related to social studies a lot more than say, science. But it's still there. And, what I mean by that is that you have to take into consideration perspectives of, summary, for example, when I talk about genetics, um, I guess you've got to think about backgrounds and things like that. Um, from the social aspect or historical aspect...but that's really my biggest takeaway from that type of coursework is really to keep in mind, keep in perspective, and be aware, and acknowledge the, um, perspectives of others...that's something that I do try to do, even though within my classroom, um, I wouldn't say that we're the worst, but we have a lot of different socioeconomic backgrounds. That's the way that we are diverse within our school district. And we are very diverse from that 
perspective. But, um, cultural standpoint, you know, it's, we're, we're pretty kind of a mild culture, so to speak.

When asked about coursework and/or PD in CDL, she stated she had not heard about it until this study and that she "hasn't had to address or acknowledge that concept before." She explained:

That is kind of something that's new to me. Um, critical digital literacy. Um, so your definition says it reflects upon the social, cultural, and historical context of digital resources, environments, participate in. That's really interesting. And, um, I think that's something that is a contemporary issue, so to speak, because it's something that maybe we haven't had to address before or acknowledge before or have to, um, keep in mind. That response prompted me to ask about the PD teachers were offered when her school went oneto-one, and if it was methodologically or pedagogically based. I also asked if there were discussion about critical theory and technology regarding the introduction of Chromebooks. She responded:

I think PD tends to be more on the practical side versus the theoretical side. I think just for, um, just for the fact that a lot of teachers are, they, they want to know how it's going to affect them, how they're going to bring it to their classroom or how it can be useful to them in the classroom. I would say a lot of teachers are not particularly interested in the theoretical reasoning behind, but I feel like they're more interested in the practical side...there's a disconnect there or something that I feel that some teachers, don't want that side because of the fact that they're just really busy people or, that I think sometimes they're, for some reason, they're just not interested in that theoretical side of things.

Based on her response, I asked the following:

Vicki: Have you seen or witnessed teachers or yourself, um, utilizing technology as a tool to help develop, uh, the critical digital literacies of your students? 
Diane: Well, I mean, I guess to a point I do when it comes to the idea of, um, assessing a resource or determining whether a resource is a quality resource or something like that. That's something that I do...if you're doing a research, I talk to them, you know, how you would assess a site for reputability, for usability.

Diane's responses indicated that she has had no exposure to or practice in applying critical theory to digital environments and tools. When asked what she felt she would have benefited most from regarding educational technology in her coursework, she stated that it should be "embedded throughout the program" and in particular, into methods courses so that teachers could see the technology tied to content.

Despite minimal technology integration exposure in her coursework, she called herself "relatively digitally literate" and stated she had a "comfortability" with technology use in her classroom. I asked Diane about how she learned about educational technology and she stated that she searches on her own for tools that work in her classroom. A prerequisite of any tool she uses is that she must be able to easily embed what she finds into her Google Classroom LMS. She went on to explain that her school district provided PD according to "the needs they want to address, not on things like digital literacy for teachers or for students." Diane believes that there is not enough educational technology PD for the district's teachers.

Diane explained that she uses technology to provide opportunities for her students to "understand and break down" science concepts. She believes that embedding the technology throughout her lessons helps her accomplish this. She values technology tools that allow practical application to her content, such as the interactive quizzes. Diane went on to state that technology integration is important "because students value it," and because of this, she includes "lots of visual resources." She views technology integration practices as "vital" to the NGSS. In 
fact, she explained that she designed her curriculum around those NGSS, which suggested that she considers technology integration as a necessary component of her curriculum.

I asked Diane if her technology integration practices were shaped by her school's technology policy and restrictions. She told me that WiFi restrictions didn't impact her use, but when the school stopped allowing Chromebooks to go home with students, she had to rethink how she assigns homework. Diane explained she has a "control issue" when it comes to student technology use as she "doesn't want them on something that is not appropriate." The way she dealt with her worries about student use is to "monitor" and "supervise them constantly." Her actions showed a protectionist approach to her student's technology use which shows her students to be passive recipients of online data sources rather than empowered decision makers/contributors in the digital environment (Burnett \& Merchant, 2011; Kellner \& Share, 2007).

As explained above, when asked about her understanding of critical theory and its application to her classroom, she defined it as being "aware of the perspective of the students sitting in the classroom" and "thinking about backgrounds." Because her students' "socioeconomic backgrounds are diverse in her school district," she has adapted some of her teaching practices. She removed a unit about genetics because she stated that "some family structures are so fragmented" and it could be "potentially embarrassing or confusing." Her practice is to "avoid those because of the population and demographics of the students." In this instance, her restriction and elimination of activities that address backgrounds and family cultures, were CDL practices which do not actually align with CDL as presented to her during participation in this study. 


\section{TPACK versus C-TPACK.}

Overall, my interview with Diane helped me gain insight about how she defined and understood C-TPACK. Based on analysis of her practices and her explanation of her understanding of critical theory as it applied to her technology use during her interview, Diane's practices did not reflect C-TPACK, rather they reflected TPACK. She did evaluate resources, which is considered just one component of CDL; however, the other three components were not considered. From her Bachelor's degree to her Doctorate degree, Diane had limited exposure to educational technology and to critical theory in her education courses.

Diane also stated that she favors technology that can be practically applied such as interactive quizzes and digital textbooks. Both applications fall low on the SAMR rubric as they do not provide students with the opportunity to create, redesign, and transform using technology (Puentedura, 2006) and they do not reflect the critical dimensions of technology use as outlined in the Four Resources Model for Multimodal Texts (Serafini, 2012). She stated that technology is important because students value it, but then limited and controlled their use of it revealing a teacher-centered versus student-centered approach to technology use during instruction. Her inclusion of visual resources during her lesson provided her with opportunities to create with technology, but that opportunity was not extended to the students.

At different points in the interview, Diane stated that technology is "vital" to her content area. It "can play a vital role within the science classroom." She stated she values technology for several reasons. She has adopted the use of the NGSS to guide her practices and believes “integrating technology into that curriculum is really important." Specifically, technology is "perfect" for the "anchoring phenomena" which is a key component of implementing NGSS guided curriculum. She believes technology can "really enrichen science and science learning." 
In fact, she stated that technology is "a great tool to help us drive our curriculum and instruction." However, she spoke of these kinds of technology integration practices as potential opportunities that she was thinking about but was not currently implementing. Diane was definitely integrating constructive technology use into her lesson preparations, but the students' use of technology during the lesson was controlled and specific. They were not creating with it or analyzing with it. In both her planning and instruction, the CDL practices were not present.

\section{Shift from teacher-centered to student-centered technology use.}

Diane incorporated the NGSS into her curriculum and teaching practices. Upon my review of the NGSS standards in light of the definition I provided earlier, the NGSS are strongly based on constructivism (Bhattacharjee, 2015; NGSS Lead States, 2013). She considered her pedagogical beliefs to be founded on constructivism and stated: "I'm definitely constructivist. I have a tendency to have students move, do things with their hands and necessarily just sit there and, you know, copy down definitions or something like that." Interestingly, while she aligns her materials, curriculum, and instruction with the NGSS, in the lesson I observed, her use of technology during instruction surrounding the NGSS was not student-centered, but rather teacher-centered which reflected traditionalism as opposed to constructivism.

Diane valued connecting content to technology and explained that because of the NGSS, she was learning more about ways that technology and her content are connected. She specifically mentioned she'd like to incorporate Project Lead the Way, a problem-based learning model which strongly emphasizes technology use, into her curriculum as she saw it as working well with the NGSS. She explained multiple examples of ways she could use technology during lessons in the future, such as with iQuest and virtual labs. Those instructional practices are decidedly different from what I observed. It was evident that as she reflected about the NGSS 
and technology, she began to see more meaningful ways she could use technology to serve the "purpose of the lesson and content," which is what she claimed is most important when she deciding about integrating technology. She stated that she needs to "let them [students] create more" with technology, and that she has "gotten away from students using" technology in a hands-on way. That would require that she give up control of the technology use when it was clear during her lesson that she was most comfortable being the authority.

During her interview, she expressed her belief that her students are not always able to make "appropriate" choices about what they engage in in online environments which is not actually reflective of a critical stance.

Vicki: Are, have you yourself, um, utilized technology as a tool to help develop, uh, the critical digital literacies of your students?

Diane: Yes, I, I think it might be a control issue for me because I don't want them to go on something that is not appropriate for them. And I think it's my, it's the level that I'm teaching with eighth grade because they're right on, I feel like they're right on that cusp that's where some of the stuff they consider appropriate for themselves and I personally would think no, that's not appropriate for them. So when we look at a, you know, different understanding of what they would consider appropriate for themselves versus what I would consider them to be appropriate for them in the classroom. What they do at home, may not be appropriate here.

Her choice to control and supervise student technology use during this lesson reflected her assumptions her students' CDL. That choice placed herself in the role of "expert" when integrating technology during instruction, which is a traditionalist practice. Rather than teaching or modeling CDL when using technology, she chose to use technology to serve the purpose of 
reviewing and reinforcing Physics concepts, which is a functional rather than critical use. The absence of engaging in the critical dimensions of technology use during the lesson was a conscious decision. Her reflection about her students' diverse socioeconomic backgrounds indicated that she recognized student diversity and she believed her actions reflected her consideration of their needs. However, her self-indicated "control issue" with allowing students to use technology reflected a teacher-centered response. In this case, while she recognized student diversity, she did not extend that critical lens to her instructional technology use practices. Instead, she eliminated the possibility of students engaging critically in an online environment.

As such, she placed herself in the role of protector, which also happens to parallel her school district's policies. Rather than employing CDL practices during her instruction, she steered clear of that possibility by strictly dictating student technology use. In fact, this practice of avoiding the engagement of students in critical literacy practices during instruction with technology extended to her decisions for other instructional activities, such as excluding a unit about genetics.

\section{Kate}

At the time of this study, Kate was an 8th grade Language Arts teacher at a large middle school with a student population of 670 . Her school had been 1:1 with Chromebooks since before she began teaching there. She was a practicing teacher for four years and was the Language Arts teacher on a team of teachers that worked together to connect the content areas. Her Bachelor's degree is in Education and she had begun working on her Master's degree in Teaching and Learning with an emphasis in Educational Technology. She explained that she had never taken a course that involved combining Language Arts and technologies. The technology 
that was integrated in her education courses served in functional ways to complete projects without the inclusion of critical analysis or evaluation of the tools used. In her Masters coursework, she took two educational technology courses that she believed incorporated CDL practices, but she explained that "it was not called that $[\mathrm{CDL}]$, but that's what we were doing." Kate described herself as "a young teacher who grew up with emerging technologies" and was always "learning about digital literacy." She went on to say that she is "comfortable with the uncomfortability" of technology use in the classroom. During high school, her technology experiences included her school going one-to-one with laptops. She explained that many of her teachers were unfamiliar with that technology, so in many cases, "the students kind of led them in the effort to understand them and use them educationally." However, she also stated that not all teachers were open to students assuming that role of teacher.

Kate highly values her experiences in online teaching communities where she has learned the most about technology integration. In fact, she chose to model her classroom after online learning communities. She believes those communities teach self-empowerment and selfsufficiency which are a priority for her in her teaching practices. Kate explained that she prioritizes both integrating the CCSS and technology in her lesson planning and implementation.

Each data source for Kate provided me with a piece of the whole picture. Her survey data indicated that she believed she had a high level of C-TPACK and had incorporated CDL into her practices. This led me to analyze her lesson/unit plans to see what her intentions were regarding recruiting C-TPACK into her instruction. Importantly, my observation of Kate showed that while her technology use during instruction reflected constructivist beliefs, she did not engage in the critical dimensions of the online environments she had her students using. Her interview helped 
me delve into her thought processes about the decisions she made and provided me with an understanding of her planning and instruction practices.

\section{Survey Results}

In response to the open-ended questions, Kate explained that she had exposure to a professor who modeled content, technologies, and teaching approaches. Her professor taught an online lesson on digital citizenship using several technology tools. The inclusion of digital citizenship as it relates to technology use in her description of the course she took indicates both that she was exposed to CDL and that it was modeled for her through the use of the actual technology tools with the content. When asked to describe when she had demonstrated or modeled content, technology, and teaching, Kate described a unit she taught to her Language Arts class. She had students use technology to research a passion of theirs, then present their results using a medium of their choice. The lesson plan that I observed was actually one of the lessons from this "Passion Project."

Kate stated that she does integrate technology daily in her teaching practices by using Google Classroom. She explained that Google Classroom provides a management system allowing for "continuous access to online tools in a central location." This indicated that she is adept at using an LMS for organizational purposes and recruits technology use in both her planning and instructional practices. This was evident when I observed her as well, as she continually used Google Classroom to present information to her students. Further, she viewed the LMS as providing her and her students with a way to introduce new technology tools to each other. This was evident in the lesson that I observed as she provided the students with a list and links to a multitude of technology tools which they could learn about and potentially use for their 
projects. This answer also aligned with an interview response where she explained the value she placed on learning from her students about new technology tools.

When asked if she incorporates CDL into her teaching practices, Kate stated she does that "quite often" as she asks her students: "Why is this the medium used for this content?" and "What new information can we gather as a result of its publication?" This shows not only her application of CDL, but also the intent to develop the students' CDL. Her answer when asked what she believes is the most important thing to consider when integrating technology was to know the purpose of the technology and what is gained by its use. This indicated that part of her process for making decisions about technology involved reflective and critical thinking to determine when to integrate technology and what kind to integrate. While these survey answers provided her beliefs about how she recruited her C-TPACK before and during instruction, her lesson plan provided data about her intentions and planning.

\section{Lesson Plan}

Technology use and application of the CCSS were evident in Kate's plan (See Appendix G), which aligned with her interview explanation of prioritizing both in her teaching practices. Her lesson was one part of a larger "Passion Project." She provided her 4D Model outline with notes that she and her teaching team created to guide this unit. The 4D Model required that the students create an original product incorporating the following steps: define, discover, design, and deliver (publish). There were several specific technology elements that the teachers had for this project that I found in that document. One was to "enter a link for a multimedia presentation onto the Passion Project Technology Link document in Google Classroom if applicable.” Technology use was encouraged but not required. This appears to align with the lesson plan that I observed where she stated "Level of technology varies depending on the nature of the project." 
In addition, the standards that she cited as being included and evaluated within this project are English Language Arts (ELA) Writing (W) 8.6 and 8.8; and ELA Speaking and Listening (SL)

8.5. Those standards (Retrieved from http://www.corestandards.org/) read:

- W 8.6: Use technology, including the Internet, to produce and publish writing and present the relationships between information and ideas efficiently as well as to interact and collaborate with others.

- W 8.8: Gather relevant information from multiple print and digital sources, using search terms effectively; assess the credibility and accuracy of each source; and quote or paraphrase the data and conclusions of others while avoiding plagiarism and following a standard format for citation

- SL 8.5: Integrate multimedia and visual displays into presentations to clarify information, strengthen claims and evidence, and add interest.

These standards have a technology integration component, which speaks to Kate's intent to integrate. CCSS W 8.8, included above, also has a CDL component. However, it is not specified to what degree critical dimensions need to be included to meet that standard such as recognizing the power structures at work in digital environments (Watulak \& Kinzer, 2013).

\section{Intention reflects constructivist pedagogical beliefs.}

While her lesson plan didn't indicate specific technology use, it alluded to technology use that was in process and would take place throughout the unit. This made me recognize the importance of looking at Kate's overall unit plan. Throughout her lesson and unit plans, Kate continually used the word "process" in relation to student learning. The 4D Project Unit Plan outlined an approach for helping students develop and create an end product that represents their 
passions which supports a constructivist approach to teaching and learning. Components of the unit plan that reflected constructivism include:

- "What are some of your personal interests?" "What is something going on in the world that you think needs to be stopped?" "What is something that you know about that others might not be as familiar with?"

- "What type of product will you be using to present your findings?" "Why is this this BEST product to use for this project?" "What are the advantages/disadvantages for this product?"

- "What did you learn by doing this project?" "How might this impact you or others in the future?" "What could be changed about how you did this project?"

While Kate did not explicitly call herself a constructivist, her explanation of her approach to teaching and learning reflected constructivist leanings. She used the following words: "authentic meaningful experiences," "creating an environment of mutual respect," "providing students opportunities to represent themselves and their interests."

\section{CDL within lesson plan.}

The creation and inclusion of the Passion Project in her curriculum provided insight about Kate's CDL in several ways. The Passion Project itself prioritized the evaluation and potential use of technology to represent the students' interests, knowledge, experiences, and backgrounds. She had an awareness about how technology tools, and the choices involved when using them, can serve as a representation of a student's culture, background, and interests. She stated "with technology, students represent themselves" and technology is "giving students a voice to kind of decide through their own choice, what works best for them." The development and inclusion of this project provided evidence of her application of critical thinking regarding 
technology tools and use as she needed to provide students with a variety of options for their presentation. Kate's lesson and unit plans included an emphasis on student choice and independent work. This supported her belief stated in her interview that providing choices for students leads to empowerment and creates self-sufficiency so students can learn to "navigate the world" in a way that is easiest for them, which she believes includes technology.

However, her focus seemed to be on critical thinking and analysis, and she did not reflect the fourth component considered critical to CDL practices: "understanding cultural, social, and historical contexts of technology use, including ethical and appropriate practices and recognizing that understanding the broader, often less-visible frameworks that shape our interactions with technology has implications for the design of instruction at all levels (Watulak \& Kinzer, 2013, p. 141)." By including conversations with each of her students about the dominant discourses and power structures represented in the digital tools and online environments the students were choosing, this component would have been present in her practices.

\section{Classroom Setting and Observations}

Kate chose this lesson for me to observe because she believed it showed technology integration in her practices. While I explained to her that my focus would be on C-TPACK as defined in the survey, it was unclear if she considered CDL when she chose the lesson for me to observe. Her classroom set up included groups of students at tables with her desk at the front and off to the side. When students entered the classroom, they sat down and opened up their Chromebooks immediately. Kate began the lesson by utilizing her LMS, Google Classroom, to provide scheduling and other organizational information about the Passion Project for the students. After a brief explanation of what the students would be working on using examples located in her G Suite (Google Classroom platform), she allowed the students to work 
independently on their projects using their Chromebooks. She then sat at a student table throughout the lesson and called each student to her individually to discuss where each was at with his/her project.

During the individual conferences, Kate asked each student questions about what technology tools they had considered and why or why not they ruled them in or out. In each instance, Kate prompted the students to think more deeply about both their choices of topics (their passions) and the means by which they would create their presentations. For example, one student was interested in using a cartoon app for his presentation about his passion about a political topic. Kate asked him to think about whether that tool would allow him to present the controversy surrounding his topic as well as best represent his stance. For students further along in their projects, she asked them to update her about their progress and show her a part of the presentation they had completed. Throughout the lesson, there was a low volume of talking between students. At the end of the class period, Kate used her SmartBoard again to put up reminders for the students about deadlines and requirements for the project.

\section{Employing CDL in practices.}

Technology was integrated in meaningful and critical ways throughout Kate's instructional practices. Her personal use of technology integration for this lesson demonstrated a high skill level with several different technology tools. In the beginning of the lesson, she explained several examples of possible tools students could use and showed how different tools could serve different purposes with the goal to find a technology tool that would most closely and clearly reflect each student's passion. Kate constantly challenged her students to critically evaluate the technology tools they were considering for their projects. In almost every case, she encouraged the students to think about and try a different or new tool for their presentations. For 
example, she asked one student "Are you doing the time lapse as you create the city?" which is an advanced skill. Kate asked a student if he is done with his project, he said "yes." She then said "upload it to YouTube. That way you can see if other people will comment." This technology use lands on the "Redefinition" level on the SAMR rubric. When redefining technology use, the technology is being used for the creation of new tasks that were previously inconceivable. It was clear that Kate was asking her students to try to reach this level of meaningfulness when using technology to represent and present their passions.

When looked at alongside the Four Resources Model for Multimodal Texts, Kate's instructional practices also showed her engagement in all four roles: Navigator, Interpreter, Designer, and Interrogator. After observing Kate, it was apparent that she expected her students to be adept in the role of Navigator, and that her goal was to help them develop the critical dimensions of their decisions and use of technology when representing themselves. She was leading them to become Interpreters of multimodal texts. Because Kate suggested and provided different kinds of technology tools, it was clear that she recognized her students represented a broad range of technological fluency, and she adapted her approach and guidance for each student accordingly. I was able to ask her further about this in her interview.

\section{Interview}

I began my interview with Kate by asking her to tell me about her exposure to educational technology. Kate was first exposed to technology integration teaching practices during high school. Kate has a very strong interest in educational technology, but did not experience tying technology directly to her content during her undergraduate and graduate coursework. She explained that her school district has a strong support system for teachers 
regarding technology as they have an in-house technology specialist to address any technology issues and needs. She stated:

we very fortunate in this district because there are so many resources to staff members, families, and students, for, um, for technology all around. So, um, just as a teacher, we have access to - like, for example, a YouTube channel that has different tutorials for $\mathrm{G}$ Suite, which is one of our main, um, like programs that we use.

She also told me "we have a specialist essentially, per school, that's able to assist which a lot of schools don't have" and "we can request have a one-on-one meeting with them to talk through something we're trying to incorporate in a unit."

Kate's experience connecting content to technology was also gained through independent research and participation in online Planned Learning Networks (PLN) of Language Arts teachers. She is active daily in online spaces such as Twitter and Instagram searching out new ways to incorporate technology in Language Arts. Kate stated "my PLN has gotten so much more extensive over the past couple years, I'm constantly on Twitter, Instagram, just actively searching out new ways to incorporate technology through models that I know. Like, people that I trust and see doing it online." When asked if within that network, CDL practices were being modeled, she stated "not always." Kate hoped to incorporate CDL practices more into her lessons and believed that programs that "globalize education" by connecting classrooms across the world is one way to do that. The PD at her school also does not address critical dimensions of technology. She explained her school's PD “as short as we possibly can. Here's how you use this in a way that's not overwhelming. So, I don't - I don't feel like we're that critical in our decisionmaking of techno." 
She also believed that technology is beneficial for all content areas. Kate stated that technology

has aided group work so much, I think. Um, and organization so much. I think that, kind of, just some teachers that I interact with in this district have found ways to help students organize themselves which is very difficult at the middle school level, to organize yourself. Um, I think that that has been a major, major plus side of technology, is us learning how to use those tools and helping students learn how to use them.

Kate added that online platforms give students a space to practice self-sufficiency and "digital etiquette" where students gain understanding about how to represent themselves and also communicate respectfully in an online community. Becoming fluent with functional technology skills as well as CDL practices are life skills she prioritizes in her teaching. It allows for collaboration between teachers and students.

When asked about barriers that she has faced with regard to technology integration, she explained that her greatest barrier was determining how to address the "fluency differences in students and their overall understanding" with regard to technology. She was also unsure about their personal use of technology outside of the classroom which she believes can lead to assumptions in the classroom. This causes her to ask "what am I assuming that kids know that maybe they don't" when planning her lessons. Kate stated that providing choices in the technology tools the students can use is her way of overcoming this barrier. Offering her students choices of online platforms and technology tools allows her to differentiate the learning environment.

If she expanded her definition and understanding of CDL, which she said she was reflecting about during the interview, she could have used this as an opportunity to explore why 
certain students have access and others don't. During the interview, she told me after she took the survey, she "Googled" CDL and decided she needs to "step it up" with regard to engaging in the critical dimensions of her and her students' technology use. The Passion Project conferences could have been an opening for her to discuss the power structures and dominant discourses that pervade digital environments. However, her focus on more functionalist technology skills during her advising sessions with her students was a missed opportunity to develop students' CDL.

Another barrier Kate cited was that the internet can be a distraction for students in the classroom. She has "been challenged" with "the management of having it all in the room." She believes that there are skills the students need to have that do not involve technology and having it constantly present makes it more difficult for her to teach students those skills. Because of this, there are times she chooses to not have the students use technology. Time is also a factor that impacts her choice to use or not use technology. She stated that teaching students how to use a website can take time away from the content.

When asked if she believes she has engaged in CDL practices in her planning and instruction, she was unsure. Based on her review of the definitions I provided for the survey, Kate did believe she was exposed to critical literacy in her Master's coursework. In those courses, she stated the instructors did not specifically call any work they were doing "critical literacy practices," but her practices during those courses seemed to align with the definitions. During her undergraduate program, she was exposed to technology tools, but did not engage in critically analyzing or evaluating those tools and digital environments. Until this interview, she explained she "hadn't really thought about it to that degree." In fact, there is also an absence of tying pedagogy and critical theory in the PD surrounding technology that her school provides which is "tutorial-based and short." Kate does believe critical theory needs to be applied to 
online environments as students "need to know how to navigate it and be able to stand up for themselves and represent themselves the best way they can. If we're not teaching that and incorporating it, then how are they going to?" She believes that modeling how to do that is necessary so that when students engage in digital environments on their own, they are able to apply what they've learned.

Kate stated that she is biased when choosing which technology tools to use in her lessons and wants to push herself to learn about different technology applications. She reflected about how her bias impacts her students stating that she has to make a conscious effort to "give up power" and let her students teach her about different technology tools. She explained that the lesson I observed was the first time she has allowed students to use tools she, herself, is not familiar with. In this way, she believes the learning will become reciprocal. Kate did express concern that she wasn't modeling CDL practices enough for her students to be able to make critical decisions about their technology use. She stated that CDL is "really difficult to teach, and more experience would be amazing." She believed she needed to "explain my side of it" when speaking about her own technology use decisions to her students more to help them learn that process.

Finally, I asked Kate what she felt would have been beneficial to have learned during her teacher education coursework with regard to educational technology. She stated that she and many of her co-workers "really struggle with teaching students how to evaluate sources." Kate connected this issue to not having learned about how to tie critical theory to technology. She does not know how to teach her students to "not take just what they are given" and to "really dig deep into the why - Why would they say this? What do they have to gain from this?" 


\section{Approach to integrating technology.}

It was clear from this interview, that Kate continually recruited her C-TPACK when planning and instructing. Her pedagogical beliefs appear to align with constructivism, however she does not explicitly state this. This is reflected in her use of differentiation to provide all students with digital environment experiences that allow them to grow their knowledge as well as create a product that represents their interests. In addition, her approach to planning technology use is student-centered as she prioritizes challenging her assumptions about her students' digital literacies. Kate explained her process for choosing when and how she integrates technology. It includes evaluating the technology to determine if it would help her reach the standards for the unit/lesson; reflecting about whether all students have the knowledge/ability to use the technology; and determining how much time it would take to ensure all students can are able to adeptly learn and use the tool/platform.

Kates' process represents three of Watulak and Kinzer's (2013) four components of CDL practices: critical thinking and analysis, reflective practice, and functional skills with digital tools. The missing fourth component is

understanding cultural, social, and historical contexts of technology use, including ethical and appropriate practices and recognizing that understanding the broader, often lessvisible frameworks that shape our interactions with technology has implications for the design of instruction at all levels" (Watulak \& Kinzer, 2013, p. 141)

Based on Kate's response when asked about her understanding of tying critical theory to the technology practices she uses with her content, she stated she was believed it was "providing choice to explore," and "knowing how to narrow down a topic." This focus on critically evaluating resources does not include the fourth component above. It also does not reflect 
recognizing the positions of power and power structures at work in those contexts which is elemental to CDL practices. Kate's goal of teaching students "how to navigate it and be able to stand up for themselves and represent themselves the best way they can" does show her reflection about and intention to incorporate that critical dimension. It also shows recruitment of her C-TPACK to guide her instructional practice choices. However, the critical component of CTPACK does not appear to be in her practices outside of reflecting about it.

\section{Reflecting and refining.}

Kate was very self-aware throughout the interview and was honest about what she knows, doesn't know, and wants to know. When specifically asked about her own CDL, she stated had this to say:

Vicki: Okay, so I know I've given you my definition of critical digital literacy, but, what do you think it personally means to you?

Kate: ...just thinking about it with middle schoolers now that I've been using -I don't know - I feel like I need to step it up a little bit in terms of being more explicit in my use of technology. Explaining my perspective in, um, in what I use and then also giving student a voice to kind of decide through their own choice, what works best for them and - and analyze their - their use of that too. I don't know. I guess, I haven't really thought about it to that degree.

During the interview, she stated that her technology choices were biased:

It's - and I hate saying it's biased. It really - because I'm choosing things that I'm familiar with oftentimes. Um, this project that you just observed is one of the first times that I've really said, "Here are a bunch of tools. I have not used 90 percent of them. But, you go 
explore them." And I have to let go of that and just be fine with that and be able to say, "I have no idea. But, you help us both together." Um.

In addition, she explained that her students could use technology to represent and empower themselves and wants to find and provide more ways to help students accomplish this.

Providing Kate with my understanding of CDL through the survey definitions and again during the interview, doesn't mean it is her understanding or that it will become her understanding. However, as meaning can be constructed based on knowledge and experiences, it seemed to be the case that participating in this study provided her with an experience which began to shape her understanding. In fact, after taking the survey, Kate "Googled" CDL so she could learn about it before this interview. She recognized the value and need for CDL practices; however, barriers seemed to override that need at times in her practices. When asked if she believed critical theory could be applied to technology, she stated:

Absolutely, yes. If we're teaching our students how to make sense of the world without technology, then we most certainly need to be doing it with technology because that is their world now and they need to know how to navigate it and be able to stand up for themselves and represent themselves the best way they can. And if we're not teaching that and incorporating it, then how are they going to?

\section{Valuing technology integration.}

It was clear that Kate valued teaching with technology. She believes digital environments offer great opportunities for students to learn and evaluate different technology tools and platforms with which to represent themselves. Kate considers learning to navigate online platforms a "necessary life skill" as students are constantly engaging in technology in and out of the classroom. She believes that if students can effectively represent themselves online they will 
feel empowered. Kate considers her students' technology knowledge as valuable in her classroom and is willing to "give up the power" or her role as "expert" in order to learn from them. She hopes that in doing so, she will be modeling how to be open about learning new technology tools.

Looking at Kate's explanation of her teaching practices in light of the Four Resources Model for Multimodal Texts and the SAMR model, respectively, helped shed light on her valuing of the critical dimensions of technology use. In her planning practices, she valued playing all four roles (Navigator, Interpreter, Designer, and Interrogator). As Navigator and Designer, she utilized her LMS to present multiple formats of information to her students through videos and embedded links to technology tools and online platforms. As Interpreter, she checked her understanding of her students' digital and critical digital literacies. Using that understanding, she planned to differentiate the learning environment by providing a multitude of technology tool choices for her students. As Interrogator, she planned to conference with each student individually to ensure she was respecting each student's voice while guiding them to critically analyze their reasons for their technology choices. Instructionally, she made conscious decisions to develop her students' CDL by challenging them to advance beyond Navigator literacy practices. Kate's Passion Project represents a transformative use of technology integration where students use technology tools to create meaningful representations of themselves and their interests.

\section{Andrew}

Andrew has been a practicing teacher for twenty-five years. At the time of this interview, he was a Social Studies teacher at a small rural high school with approximately 350 students. Like Kate's and Diane's schools, his high school is one-to-one with Chromebooks. Andrew 
employs a flipped classroom model. In a flipped classroom, the lecture is typically viewed/listened to by students the night before, allowing the use of classroom time to work through and discuss the material that was covered in the lecture (Abeysekera and Dawson, 2015). The teacher then uses class time for "active in-class tasks and pre/post class work" (Abeysekera and Dawson, 2015, p. 2). Andrew explained about how he used the model for his class: "I have the lecture videos in there; that frees up class time, and then I chose to use the class time to add to the materials and they can ask me questions." The class that I observed Andrew teaching was History of Western Civilization for 9th and 10th grade students.

Andrew earned his Bachelor of Science degree in Radio and Television and also a Bachelor's degree in Social Sciences Education. He has a Master's degree in Communication and Media Studies and was about to defend his dissertation for his Doctorate degree in education. The focus of his dissertation study was flipped classrooms. Andrew explained that he had "some courses" in his graduate degrees that introduced technology tools, but that most of his educational technology PD was self-directed and driven by his personal interests. Professional development that he has had regarding technology has largely been short 45 minute workshops in which teachers were introduced to a new tool and that tool served as a substitute for what they are already doing in the classroom. He explained that technology PD at his school is "not transformative." Andrew has had coursework in critical theory, but not specifically in tying critical theory to technology. He explained that his approach to all things digital is to "recognize that there is bias there" and "see how this was influenced by that."

Because of his strong interest in educational technology and his background in media, Andrew sought out an LMS that could accommodate his advanced technology skills and his flipped classroom model. He chose a platform called "Schoology" where he houses all of his 
class materials, textbook, and lecture videos. He has designed his LMS to be highly interactive for the students. Because of his adeptness with Schoology, he was asked to become a "Schoology Expert" by the corporation. In that role, he teaches other teachers how to innovatively build their LMS platforms.

Each data source for Andrew provided me with a piece of the whole picture. His survey data indicated that he believed he had a high level of C-TPACK and had incorporated CDL into his practices. This led me to analyze his lesson/unit plans to see what his intentions were regarding recruiting C-TPACK into his instruction. Importantly, my observation of Andrew showed that while his personal technology use during planning and in the virtual classroom he created using his LMS as his platform reflected constructivist beliefs and some components of CDL practices, he did not engage in the critical dimensions of the online environments he had his students using during instruction. My interview with Andrew helped me delve into his thought processes about the decisions he made and provided me with an greater understanding of his planning and instruction practices.

\section{Survey Results}

For the open-ended survey questions, Andrew stated "not applicable to me" when asked to describe an episode where a professor or an instructor effectively demonstrated or modeled combining content, technologies, and teaching approaches in a classroom lesson. He did describe a time when he believed he effectively demonstrated or modeled that combination of knowledge. Using the flipped classroom model, he created an interactive video on his LMS that connected a punk rock song from a popular current band to the Roman Empire. In it, he introduced "history's three big questions: who are we, where did we come from, and where are we going?" Also in that video, he compared history to a jigsaw puzzle with missing pieces with no accurate picture 
to use to help assemble it. This example incorporates a high level of technology use that aligns with the highest level of technology integration according to the SAMR and Four Resources models. His example is reflective of a transformative use of technology and is a "Redefinition" as he redefined technology allowing for the creation of new tasks previously inconceivable (Puentedura, 2003).

Andrew's description of his teaching activities place him in the roles of Navigator, Interpreter, Designer, and Interrogator according to Serafini's (2012) Four Resources for Multimodal Texts. Andrew's answer to the next question indicated that he is integrating technology into his daily teaching practices. Specifically, he cited use of the flipped classroom model, Chromebooks (his school is 1:1), and his Schoology LMS. In addition, he uses screencasting, embedding, and self-paced organization via online monitoring that both he and the students participate in.

The remaining open-ended survey questions focused on CDL. Andrew stated that while he did not learn about CDL in his teacher education program, he does believe he incorporates CDL in his teaching practices. He provided two examples. In the first, he wrote the following: Recently students compared the English Bill of Rights, the American Bill of Rights, and the French Declaration of Rights of Man and the Citizen. In this analysis students also looked at the various levels of society in each country and the varied goals or ideals passed on their social status. For example, while France had its three estates, the Third Estate contained a wide spectrum of people, from doctors, lawyers, wealthy merchants, to poor peasants and unemployed city dwellers. 
In his second example, Andrew explained that when the students view his lecture video the night before the lesson, they must respond to questions that he calls "Universal Response Questions" or URQs. See Figure 5.2 below for the URQ sheet he gave me.

\section{Figure 5.2. Andrew's URQs}

\section{After reading the selection or viewing the video, please answer the following questions.}

1. List 2 things you found to be either interesting or important and explain WHY you think so.

(You must explain why you find it interesting or important for each item.)

\section{List 2 things that you either did not understand OR that you want to know more} about.

(This can be both you didn't understand, both you want to know more about, or one of each.)

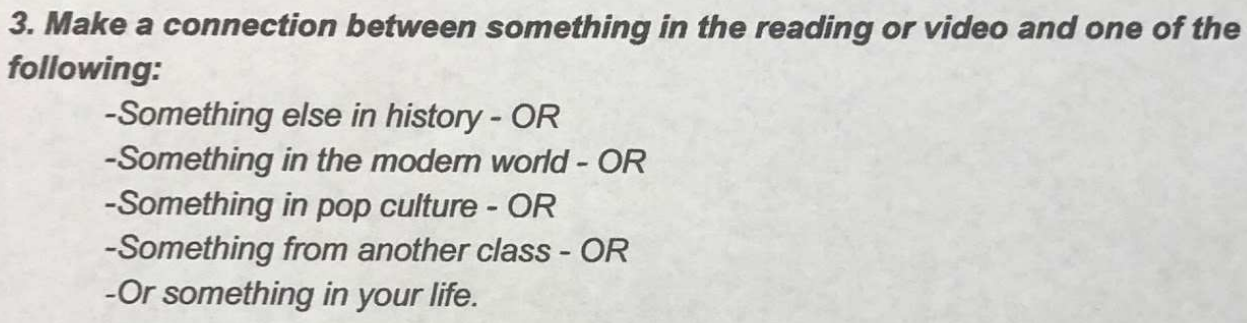

The inclusion of URQs provides Andrew with insight about individual student understanding and affords the students an opportunity to "construct their own understanding and knowledge of the world through experiencing things and reflecting on those experiences" (Bhattacharjee, 2015, p. 65) resulting in the personalized construction of meaning.

Using Watulak and Kinzer's (2013) four components of CDL as a guide, both examples show his application critical theory to content and to some extent, to technology. In each case, 
technology served in a functional way where he was able to "identify and use appropriate technological tools to further pedagogical and communicative goals" (Serafini, 2012, p. 141). Andrew's inclusion of the URQs with materials and resources from his LMS show his engagement in reflective or critical analysis practices regarding the "social, cultural, and historical contexts of digital resources and environments as they are used and participated in" (Watulak \& Kinzer, 2013, p. 135). When examined in light of the SAMR rubric, Andrew's instructional activities do provide an opportunity for students to reflect on their cultural worlds, but the digital tools (the LMS and discussion area of the classroom website) provided are largely functional and substitutive or augmentative, resulting in enhancements to Andrew's lessons rather than opportunities for transformation. In addition, those activities do not examine the social structure of the digital environment nor do they recognize the positions of power at work specifically in online platforms.

The final survey question posed was: What do you believe is the most important thing to consider when integrating technology? Andrew stated that integration should support his pedagogical goal, but did not expand on his pedagogical beliefs. He explained that "The technology should allow for the implementation of higher order and creative thinking, not simply be 'domesticated' to conventional teaching ideas." This seemed to suggest that technology should enable a teacher to incorporate critical thinking into lessons. There is a difference between creating with and within digital environments to represent one's own culture and identity which reflects CDL practices, and using technology as a substitute for traditional teaching methods. It was important to analyze his lesson plans and observe Andrew to gain an understanding of why he believed this and how he translated those beliefs to practices. 


\section{Lesson Plans}

As stated earlier, Andrew uses a flipped classroom model where he houses and delivers all of his materials for his lessons within his Schoology LMS. He did not provide me with a copy of his lesson, therefore it is not included here. Instead he provided me with a link and granted me permission to access it. For this lesson, he used Schoology to provide the students with a link to his video lecture with discussion questions the night before the class I observed. In fact, he granted me access to all lessons and materials for his entire semester which enabled me to also review the unit plan. When I emailed Andrew asking him to choose a class period during which he integrated technology for me to observe, he explained to me that "every class uses technology. All materials and content are online. So, generally speaking, tech is used everyday." He then offered to let me choose the date for observation based on my review of his semester lesson plans on the LMS.

Because I wanted to let the teachers guide me as to when they believed they would be integrating technology, not when I believed they would, I chose a week out of his schedule and asked him to choose the lesson for me to observe. As he believed that technology was present in every lesson, my choice of weeks simply rested on when I was most readily available to get to his school. Andrew chose a lesson and explained that he planned to go over reading questions they completed the day before as well as new questions he "tossed out to connect the material from the past to other things in history and the present."

After my online review of the lesson plan and materials for that day, it appeared that the students were required to read a chapter from the textbook, watch a video, and answer questions about that chapter and video using the classroom website. The questions were in multiple choice format and the students answered them as they read. In addition, students needed to complete the 
URQs before class. The technology that Andrew planned to use for the lesson included using the online textbook and a link to an online Kahoots quiz which he intended students to take during the lesson. Kahoots is a game-based learning platform where teachers can enter questions with multiple choice answers (Retrieved from https://kahoot.com/what-is-kahoot/ ). Students enter answers on their own devices which are then recorded and scored in real time. I was allowed access to the Kahoots quiz and noted that it contained several embedded links and images of primary resources that he found online. In it he included embedded images that reflected the glorification of the war by the government, such as propaganda posters, and images reflecting the positions that women and African Americans occupied in society at that time in history. Andrew planned to break students into teams to take that quiz and to discuss each answer in light of the materials the students had to read the night before.

The standards Andrew cited as being met in this lesson focused strongly on primary and secondary source analysis. Specifically they included from the CCSS: ELA- Literacy.RH.910.1, ELA- Literacy.RH.9-10.2, ELA- Literacy.RH.9-10.4, and ELA- Literacy.RH.9-10.5. He also cited the following from the Illinois Learning Standards for Social Science (ILSSS) as being met in this lesson: SS.H.1.9-12, SS.H.2.9-12, SS.H.3.9-12, SS.H.5.9-12, SS.H.7.9-12, SS.H.8.912, SS.H.10.9-12, SS.H.11.9-12, and SS.H.12.9-12. Upon review of those standards, they do not include the use or analysis of technologies. In fact, he does not include the two standards within those that call for students to find resources on their own and to study how technologies of the time impacted individuals. The focus of those standards is the evaluation and analysis within and across historical eras and contexts focusing on how people and institutions shape and promote change. There is a critical literacy emphasis in those standards to "analyze key historical events 
and contributions of individuals through a variety of perspectives, including those of historically underrepresented groups" (SS.H.7.9-12; SS.H.8.9-12).

\section{Demonstrated transformative technology use.}

After accessing Andrew's LMS to review his lesson plans, it was clear that Andrew recruited his C-TPACK from the inception of his flipped classroom through the final lesson plan of his semester. He developed his LMS to be a virtual classroom that would both enhance and transform his teaching practices. The literacy practices he demonstrated in doing so show him to be highly skilled in the roles of Navigator, Interpreter, Designer and Interrogator (Serafini, 2012). The planning that Andrew engaged in to create and develop this unit provided evidence of transformative technology use (Puentedura, 2003).

Andrew's intended instructional practices with technology appeared be serving as an enhancement to Andrew's lesson. This included the use of the Kahoots quiz with embedded primary resource images that would guide his discussion of the materials students engaged with the night before. This technology integration appeared to be augmentative as it would substitute for traditional practices and provide functional improvement in the form of a providing a collaborative platform for students to engage in. While the technology use for instruction activities for the students appeared to be augmentative in nature, that stood in contrast to Andrew's transformative technology use in his planning practices. His virtual classroom seemed to be where students had more opportunities to critically engage with the online materials.

In addition, Andrew did engage in CDL practices in his planning. Throughout his Kahoots quiz, he embedded images of, and links to, primary resources that he intended to use to guide the discussion about each answer and develop the students' critical analysis skills of resources to meet the standards he cited. The images and links he chose showed that he reflected 
on the social, cultural, and historical contexts of digital resources and environments. He stated on his lesson plan that there would be "review and discussion with students" about the essential questions posed during the quiz. One such question was: "What was the effect of total war on ‘ordinary’ citizens?” His Kahoots quiz presentation and discussion bridged the students' world with the past using those primary resources and the digital environment.

\section{Classroom Setting and Observation}

At the front of Andrew's classroom was a stage that spanned the entire wall. To the right of that stage was Andrew's desk. Throughout the main area of the classroom, there were tables with groups of chairs around each. Andrew explained to the class that they would be forming teams to take a Kahoots quiz and that each team would be allowed to briefly discuss each question and then submit one team answer. He explained that during the quiz, he would take time to tie the question back to the material they read and listened to the night before. There were 33 questions on the quiz. The resources were all presented from a presentation housed on his laptop which he controlled with a remote control device and then projected onto a large screen at the front of his classroom.

Several of the quiz questions contained primary resource images and links. Once the question was answered, the link or image appeared, and Andrew explained what the students were seeing. For example, one question that Andrew had was: True/False - As the war continued and casualties grew worse, governments on both sides had to deal with growing opposition to the war using force, censorship, and propaganda." The students discussed this in their groups and then entered their answers. After the answers were entered, Andrew showed multiple images of

propaganda used by the U.S. government and also real photos of people protesting. Andrew used those links and images to introduce critical theory to the students. He used war propaganda 
posters to discuss how the government "marketed" the war to the public to gain and keep their support. He explained that artwork was used to show the public what war looked like as were photographs; however, the paintings and photos that were provided to the public were often chosen by the government's for specific purposes, such as aiding in the recruitment of soldiers.

Andrew continually placed the events of the war and the images he showed in social and historical contexts. When speaking about the weapons used during the war, he pointed out parallels to recent wars. When showing photos of soldiers and their spouses/girlfriends celebrating their send off, Andrew explained that "the government wanted to generate excitement about joining the war." Several times during the lesson, he told the students to recognize the source and the possible motives and agendas that were being represented in the images the public was shown.

The students were very engaged during the quiz. Each team had discussions about the answers before submitting them. During the quiz the noise level was mostly low, and Andrew controlled that with continual "shushing" and walking around the room between tables as he navigated through the quiz. Andrew asked the students three times between quiz questions if they had anything to add or additional questions. One time, a student asked a clarification question about the date of a battle. While Andrew did most of the talking to the whole class, as stated earlier, the students were collaborating about the materials they read and watched the night before to determine their answers. However, this is not a constructivist practice as there appeared to be right and wrong answers.

\section{Constructivist practices.}

A flipped classroom is technology and student-centered (Gilboy, Heinerichs, \& Pazzaglia, 2015). The flipped model in general, and Andrew's teaching practices used in his 
virtual classroom, reflected a constructivist approach to teaching (Bhattacharjee, 2015; Roehl, Reddy, \& Shannon, 2013). Teachers who employ a constructivist approach to teaching and learning prioritize connecting previous knowledge with new knowledge, providing opportunities for students to work together to understand concepts, and incorporating authentic experiences where the knowledge can be applied (Bhattacharjee, 2015; Good \& Brophy, 1994). This aligns with a primary objective of a flipped classroom which is to free class time to delve more deeply into the material and have time to apply the concepts with the teacher present rather than individual students doing the work at home (Tucker, 2012; Roehl, Reddy, \& Shannon, 2013). Interestingly, Andrew's question formats were True/False and multiple choice which are not reflective of constructivism, yet critical theory was present in many of the questions. See Figure 5.3 below for example of a quiz question which alluded to the economic and socioeconomic disparities exacerbated by the war.

\section{Figure 5.3. Andrew's Quiz Question}

The decision to remain in the war did not satisfy the workers or the peasants who wanted above all an end to the war. Additionally, the government faced a challenge to its authority from , councils composed of representatives from the workers and soldiers.
A. Council of People's Commissars
B. Soviets
C. War communism
D. Duma

While this question may have required students to connect materials, Andrew only provided multiple or binary choice (True/False) answer options in his quiz. Consequently, there was not an opportunity for students to critically discuss and/or locate resources to support their opinions and 
express their personal meaning and thoughts about the materials. After looking at Andrew's LMS where he housed his virtual classroom, and also looking at the activities he had students engage in at the LMS such as his URQs and whole class comments areas, it was apparent that he offered opportunities for student to critically reflect about the materials online, but those opportunities were not present during his lesson.

Exposing students to primary resources that reflected the social and historical contexts in which the war occurred reinforced important events and also provided opportunities for students to connect those images to previous knowledge. Andrew's use of digital resources was abundant and critically driven. He continually pulled up images and accessed links during the lesson to reinforce his comments. These ranged from real photos of people being "gassed," to maps of the trenches from WW1, to propaganda such as women flocking around soldiers used during the war to garner government support. After each image he displayed, Andrew explained how that image was used to influence people. For example, if you enlisted in the armed forces, you would have women wanting to date you. If you fought in the war, you would come home to parades celebrating your service. Andrew explained these scenarios, but he did not generate discussion with the students about them. He covered a massive amount of material in that short time period. In his interview he stated he "has a wide range of students in there, kids with IEPs," which has challenged him because "they have to meet the targets" and he tries to give them as much information as possible to ensure they will succeed so his lessons are "just over the content." This could have contributed to his decision about how much discussion time he felt he could afford. 


\section{Roles of technology use.}

The focus of Andrew's instructional activities using technology integration was on remembering, applying and understanding the materials, which aligns with substitutive and augmentative technology use on the SAMR rubric (Puentedura, 2003). Puentedura (2003) defined this type of technology use as an enhancement to instruction rather than transformative. While Andrew didn't have the students use technology in transformative ways during this lesson, he was using technology himself to help transform their thinking about media resources that were being used during the war. In my observation notes, I wrote that during the lesson he told students to "recognize the way that people slant things to their favor" and to "look for the subliminal message" of the images he displayed. He encouraged them to critically think about and analyze the intent of the producers of the images; however, he provided his analysis rather than sought their analysis. While the students collaborated to come up with quiz answers, there was little interaction or discussion between Andrew and the students. He did periodically check for student understanding, but did not engage the students in discussion about the topics.

The students' role in preparing for this lesson and during this lesson was that of Navigator. They had to "move in and out of non-linear structures, hypertext, and visual images" (Serafini, 2012, p. 28) during their homework the night before. Once in class, they had to connect their readings and understandings with questions and new images, which also aligned with Navigator literacy practices according to Serafini (2012). By providing his embedded presentation of the quiz and his interpretation of the images, Andrew modeled the roles of Interpreter, Designer, and Interrogator (Serafini, 2012). Not having students construct and discuss their own answers and meanings was a missed opportunity to engage with the resources more critically thus allowing them to become Interpreters and Designers. Interpreter practices 
include "constructs understandings from multiple perspectives, including the author's intentions, textual references, personal experiences, and sociocultural contexts in which one reads; draws upon available resources to make sense of what is written or depicted; draws upon experiences with other images and texts during their act of interpretation; and recognizes that images are not neutral or objective representations of reality" (Serafini, 2012, p.29). All of those practices aligned with the standards that Andrew hoped to meet for this lesson, so it seemed that this was his intention; however, based on my observation of this lesson, I am unsure that he met those standards.

\section{Inclusion of critical theory.}

Andrew's lesson involved connecting critical theory to technology. His focus was on critical analysis of primary resources accessed online that were related to the war. He engaged in his own reflection about and critical analysis of those resources throughout the lesson. He explained the cultural, social and historical contexts in which those resources were located. Importantly, he continually emphasized to the students the importance of questioning the origin of sources and of searching for the intent behind the resources thus questioning the power structures at work during that time in history. Throughout the lesson, Andrew made connections for the students about the images/links and the materials they read and listened to the night before. Absent in this lesson was how underrepresented groups were impacted by historical events, which is a critical literacy objective in the standards he cited in his lesson plan. Andrew's practices clearly showed his engagement in the critical dimensions of his content, but did not include the students' engaging in critical dimension of their technology use. 


\section{Interview}

I began my interview with Andrew by asking about how he learned about educational technology. The technology PD that has been offered during his teaching tenure has largely been short tutorial workshops where the technology is "domesticated instead of being used to innovate." He explained that the PD enforced substitution which, in his opinion, reinforces traditional approaches to teaching. Andrew values connecting technology to content and he believes that connection is lacking in the PD required by the school. He also is a proponent of learning by doing. He taught an online university course in Educational Technology for teachers where he "threw out the syllabus" that was provided for him because it did not have students using their own materials to create projects.

Regarding what he considers most important when choosing an online platform to use, he explained it must offer multiple means of assessing a student's understanding. Andrew's goal is to "give students lots of ways of getting to the same material" and "instead of saying to students 'here's your test,' I give them the option of taking a test or writing a paper or making a video.” He said he "gives links to the video files so that when you get back home you can revisit and remember materials." In addition, he believes that students are most engaged when an LMS is visually appealing as that makes learning "a little more illustrated" and "students find it more fun." He believes that there are many powerful tools to choose from and teachers should find the ones that have an equally "powerful impact." He believes that technology loses power if teachers aren't shown how to apply their own materials to it. His technology integration decisions are guided by research he has done for his doctorate and his constant questioning about how to better engage his students with the material. Andrew believes the way he integrates technology helps students connect information they learn throughout the semester. Housing all of his course 
content in one place is a priority as he can build and access his resource library quickly enabling him to make connections throughout the semester.

Andrew stated that his pedagogical beliefs were "Constructivist." He explained that he pushed students to make connections and to "understand how events were shaped by previous events and outcomes." He emphasizes "how the past still affects us today" when teaching. When asked how his pedagogical beliefs relate to his beliefs about technology integration, he explained that his beliefs support technology use because he is able to differentiate his methods to reach the diverse needs of his students. For example, he offered formative assessment online while students watch his lecture videos. That provided him a snapshot of student understanding which he addressed in class the next day. He also explained that the flipped classroom model which relies on technology for delivery of materials "saves time for learning and allows for exploration" of students interests.

When asked about his understanding of critical theory, he had much to offer. He stated: You've got to challenge the authority. You're questioning things. And it's just part of being a historian. Just, you tell them in that video what's in the textbook - history textbooks can be really boring because history textbooks give the most accepted version of events. So, the critical theory part of that is question what you see there. And the book, you should know, that we're reading is good to question assumptions, we have to question on societal values and how we value things and why. I'm not saying you have to be critical, but being critical is like saying - you're not saying - you're saying it's all wrong, it's all wrong, but I am asking you to question it and understand that almost everything in it has some viewpoint they're trying to steer you towards. 
He believes that critical theory is founded on questioning. While he stated that he had never been exposed to CDL in coursework or PD, Andrew believed he did apply critical theory to technology. He explained that he prioritized looking closely at a tool to "see how it works" and "see that it makes sense" before he used it. He went on to offer more about CDL specifically in reference to YouTube videos when he explained: "For me, it's my voice of reason right now. If you don't recognize that bias that's in there, don't get critical, then you, that's what we're gonna get by using those resources." He explained there is bias in all materials that teachers use that needs to be examined.

Andrew pointed to several barriers he faced regarding technology integration. First, as explained above, the PD does not include hands-on practice or application using one's own materials with the tools. In his opinion, "showing teachers how to use the technology is radically different than showing them how to teach with it." The PD offered also largely promotes new tools that, in his opinion, most likely will not be around very long. He believed that teacher education and PD also needs to include learning how to use an LMS.

In addition, the many restrictions placed on student use of the Chromebooks at his school, such as not allowing video creation tools and restricting students' ability to engage in online discussions, is a significant barrier for him. This has made it difficult for Andrew to incorporate activities for students to create with technology. In fact, he has eliminated several projects because of school-imposed Chromebook restrictions and monetary limitations which resulted in not renewing licenses to use certain software. Another barrier for Andrew was time. He stated he does not have enough time to do all that he wants with technology in his practices. The most support Andrew has received has come from his position with Schoology which provides 
opportunities for him to develop his technology skills continually. Otherwise, his educational technology use was largely driven by pursuing personal interests during his personal time.

\section{Transformative personal technology use.}

From the development of his flipped classroom to the components of each lesson plan delivered via his LMS, it was evident that Andrew recruited his C-TPACK in his teaching practices. During the interview, Andrew explained that his primary purpose for his technology integration was "to enhance his teaching and lessons." While this was his stated purpose, it was clear that Andrew's fluency with multiple online platforms and technology tools allowed him to use technology in a transformative way in his planning. As noted in my observations, his instructional practices with student technology use that I observed were not transformative and reflected his stated purpose of enhancement. He did not have students engage in meaningful technology use and consequently his presentation of materials was largely didactic and student use was largely substitutive. The objectives for his lesson were centered on specific CCSS and Illinois Learning Standards for Social Science. Those standards emphasize analyzing primary and secondary sources and identifying cause and effect relationships with no specific technology use for students stated. In addition, he cited limitations and restrictions imposed on Chromebooks as hindering the his ability to have students create with technology (such as videos) and engage in critical dimensions during his lesson.

\section{Sara}

At the time of this observation, Sara was teaching junior and senior level high school Spanish classes at a high school with an enrollment of 1,000 students. Her school is considered a laboratory school for a nearby university. According to the high school website, Sara's school “serves as clinical experience and practice sites for pre-service teachers and experimental 
teaching activities. The schools provide a 'living laboratory' for research and applied practices to improve teaching and educational practice"

(https://uhigh.illinoisstate.edu/blogs/schoolinfo/about-us/ ). Sara has a Bachelor's degree in Spanish Education, a post-graduate certificate in the Teaching of Writing to Middle School and High School Students, and a Master's degree in English Studies. She is also Nationally Board Certified in World Languages. Sara has been teaching for twenty-four years.

Sara did not receive much exposure to technology integration in her education coursework. She recalled taking one course called "Microcomputing for Education." She explained that the course was so long ago that the internet was not publicly available at the time. She did more recently take a course called "Technology for the Teaching of Writing" for her post-graduate certification. During that course the instructor modeled tying technology to content which "steered her into" using technology more in her teaching. The instructor for that course introduced Sara to technology tools and websites that she had never heard of but has since then used in her Spanish courses such as Audacity, VoiceThread, and Blackboard.

Sara's high school is one-to-one and she allows students either use the laptop or their phones during her lessons. There is a Technology Director at her school and the teachers are "really pushed to present at conference" the ways they are integrating technology. The class that I observed Sara teaching was Advanced Placement (AP), Spanish 5.

Each data source for Sara provided me with a piece of the whole picture. On the survey, she indicated that she had a high level of C-TPACK and had incorporated CDL into her practices. This led me to analyze her lesson/unit plans to see what her intentions were regarding recruiting C-TPACK into her instruction. Importantly, my observation of Sara showed that the "C" in C-TPACK was not present, her technology use was substitutive and her technology 
integration practices during instruction served a didactic purpose. Her interview helped me delve into her thought processes about the decisions she made and provided me with an understanding of her planning and instruction practices.

\section{Survey Results}

In her open-ended question answers, Sara explained that she had exposure to a professor who modeled content, technologies, and teaching approaches. During a lesson in a post-graduate certification course, her instructor demonstrated how to use Weebly to create an online website and demonstrated how to tie that directly to her content area. When asked if she had modeled combining content, technologies, and teaching approaches, she explained that she taught her English language learners (many of whom had never used a computer before) how to create a PowerPoint for a grammar presentation. She stated that she integrates technology every day in her class and her practices include using online platforms such as BlackBoard, Audacity, VoiceThread, and "many others." In fact, when I observed Sara, she used a PowerPoint presentation which was housed on her LMS. In addition, within the PowerPoint, she had embedded her Kahoots quiz as well as images, links, and videos.

Regarding her knowledge and incorporation of CDL, she stated she did not learn about CDL in her teacher education courses; however, she indicated that she incorporated CDL by "spending a lot of time learning how to read sources on the internet and how best to use that as support in a research paper." This explanation reflects some, but not all components of CDL (Burnett \& Merchant, 2011; Watulak \& Kinzer, 2013). When asked what the most important thing to consider when integrating technology, she stated that "there needs to be a why." This indicated that her use of technology integration in her teaching practices was both reflective and intentional. While these survey answers provided her beliefs about how she recruits her C- 
TPACK before and during instruction, it was important and necessary to analyze her lesson plans and observe her to see if/how her self-indicated C-TPACK presented in her lesson plans and teaching practices.

\section{Lesson Plan}

The lesson Sara had me observe was her AP senior level class. She provided me with both her unit plan and lesson plans for the entire week. (See Appendix H for Sara's lesson plan). Because this is a senior level class, Sara explained to me beforehand that she requires her students to speak in Spanish as much as possible. I am not fluent in Spanish, which could be considered a limitation in this study. I was concerned about this as I did not want to misrepresent her and her recruitment of C-TPACK because of a language barrier. To help with this potential limitation, I made note to use the interview as a means for ensuring I had as much information as possible and to fill in any blanks that may have occurred because of my lack of fluency.

Sara was teaching an AP course which the College Board calls "AP Spanish Language and Culture." The College Board provides themes from which the questions for the exam will be created. These themes "help teachers integrate language, content, and culture into an interrelated series of lessons and activities that promote the use of the language in a variety of contexts" (Retrieved from https://apstudent.collegeboard.org/apcourse/ap-spanish-language/coursedetails). Sara's lesson plan did not provide specific standards as objectives. Instead, she used wording directly from the College Board's Advanced Placement Program website. The essential questions that Sara used on her lesson plans included:

1. How are perceptions of beauty and creativity established?

2. How do ideals of beauty and aesthetics influence daily life?

3. How do the arts both challenge and reflect cultural perspectives? 
In addition, the AP Curriculum guide directs teachers to provide "authentic materials, and learning activities that help students consider themes across time and across cultures" (https://apstudent.collegeboard.org/apcourse/ap-spanish-language/course-details\#/) and they provide suggestions about which materials and activities could be used.

Sara's lesson plan also included a section called "Suggested Assessments/Products." In that section, there was a long list of potential activities AP teachers could use during the "Beauty and Esthetics" themed unit. These appeared to be provided by the College Board. There was no mention of technology on the lesson plan Sara provided, however, this was a lesson she chose for me to observe because she believed it showed her integration of technology.

\section{Incorporating critical theory.}

While there was no explicit use of technology cited in Sara's lesson plan, it is possible to assume that several of the "Suggested Products" could be online resources. That said, because her lesson plan did not have specific technology use listed on it, it was not possible to see how she intended to recruit her C-TPACK for this lesson. As a result, the focus of my coding centered on analyzing how she intended to engage in the critical dimensions of her teaching.

The "Essential Questions" provided by the College Board are aimed at analyzing perceptions and opinions about the concept of beauty in different cultures. As such, it is logical to assume that a teacher using this curriculum would be employing critical theory. The "Suggested Products" that Sara listed on her plan required her to look at those provisions critically to see how they could be included in her instruction practices.

\section{Classroom Setting and Observation}

The lesson I observed Sara teach was a senior level Spanish AP course. The classroom was set up with tables for four to five students. Sara had a SmartBoard at the front and center of 
the classroom with her desk off to the right of it. When the students walked in, they were reminded by her to speak only in Spanish. Sara asked them to get out their technology and log-in to the Kahoots website to take the quiz she had prepared. The quiz was a vocabulary review using words about beauty perceptions in different cultures. The students entered their answers individually, but it was viewed as a class on the Smartboard. After the quiz, students were told to put away their technology and get their homework worksheets out that they completed the night before. Sara then began a PowerPoint presentation about perceptions of beauty using the five worksheet questions as her guide. She used different images for each of the questions and provided examples for each. For example, one question was "how are ideals of beauty influenced?" The images she showed were of a book, a work setting, and a mirror. There was very little class discussion about one question and no discussion about the others. After the presentation, Sara broke the students into pairs and had them tell each other their answers from the worksheet.

After that activity, she showed a video news clip, in English, of a town in Africa where overweight women were exercising wearing burqas. The video explained that being overweight in that culture was considered beautiful and a sign of wealth; however, obesity is a health risk for the women and they are conflicted between being beautiful and jeopardizing their health. After the video, Sara explained in Spanish about the cultural differences between that country and the United States concerning perceptions of beauty. There was no class discussion. Sara then distributed another worksheet and asked students to fill it out while she continued the presentation. She showed images of a Barbie doll with and without make-up, and Barbies of different ethnicities. She asked the students to compare them. Then a DOVE Self-Esteem Fund video was played showing how advertisers change the dimensions of faces and hair to make 
them "more beautiful" so they can sell more products. Sara told the students to discuss in their pairs what they had just seen using the questions on their worksheets as guides.

After the pairs discussed, she showed a final video called "What is Beauty?" which showed how beauty has been defined differently over each decade in time. The narrator explained that society is marketed "things to make you beautiful." When the video ended, Sara spoke for ten minutes providing answers for the students to write down on their worksheets. Students were told to turn in the worksheets and the class ended.

\section{Constructivist and traditional teaching methods.}

When asked during the interview about her pedagogical beliefs, Sara did not provide specific answers. However, it was clear from her interview responses and teaching practices that I analyzed that she valued and relied on both constructivist and traditionalist teaching methods throughout her lesson. The technology Sara used during the lesson was a Kahoots app and a PowerPoint presentation in which images and videos were embedded. When using PowerPoint, she had the students fill out paper worksheets. On the one hand, she embraced the opportunities technology afforded her to create and deliver materials to her students which reflected constructivist practices (Bhattacharjee, 2015). Sara created her PowerPoint to engage her students in the material and discussion of the unit theme which is a student-centered practice. On the other hand, she had her students create and deliver their responses via traditional means and controlled their use of technology when it was allowed. In fact, she asked students to put away their technology and gave them worksheets which are considered a traditionalist teaching method (Sawers, Wicks, Mvududu, Seeley, \& Copeland, 2016). While the Kahoots quiz provided an opportunity for the students to use technology, that use was substitutive and did not invite critical analysis and constructing meaning using technology (Gorder, 2008; Meyers, Erickson, \& Small, 
2013; Puentedura, 2003). While her technology use in her planning and presentation during instruction reflected constructivism (Bhattacharjee, 2015; Terwel, 1999), the technology she had the students use was substitutive.

As stated earlier, paper worksheets were continually used through the lesson. One contained the essential questions for the unit and another had students use their new vocabulary words to answer questions about the images she presented in her PowerPoint. At the same time, every student had and used technology devices including Chromebooks, phones, and iPads during the lesson. It is possible that Sara chose traditional methods, such as worksheets, to serve a different purpose than conversation and discussion. As the students were just learning beauty vocabulary, engaging in critical analysis discussions with those new words could be unrealistic. In fact, the discussion component of the lesson was very limited. This could also be due to the students' learning curve when using new vocabulary words. Regardless, the students did not use technology in meaningful ways and the technology served as an enhancement for this lesson.

\section{Presence of critical dimensions in presentation and activities.}

It was clear from her preparations and her instruction that Sara was reflective about technology integration for this lesson and unit. The technology served a didactic function for the theme of the unit which aligned with her statement from her survey that said she believes about technology use: "there needs to be a why." In her planning, Sara critically analyzed resources and created a PowerPoint presentation embedding an interactive quiz, videos, and images. Those acts required fluency in a multitude of technology tools and the critical analysis of those tools and the resources she chose to include. Consequently, her C-TPACK was recruited in order to engage in those practices. However, during instruction, her technology use with the students was largely substitutive and didactic in the sense that her purpose seemed to be to use technology to 
teach specific course materials and not have the students use the technology for anything outside of this specific purpose.

Despite the fact that the essential questions for this lesson invited critical reflection about perceptions of beauty in different cultures, Sara did not involve students in critical engaging in online environments to answer the questions. Instead, she critically engaged and provided her resources to the students in a PowerPoint presentation and on worksheets. Had Sara engaged the students in their own analysis and critique of the dominant power relationships that result in problematic perceptions of beauty in online resources, such activities would have shown her and her students recruiting CDL practices.

\section{Interview}

I began the interview by asking Sara about coursework that involved technology integration. She explained that her technology integration practices increased as a result of the graduate course she took called "Technology for Writing." Sara stated that the instructor modeled the connection between content and technology which "opened her mind" and "motivated" her to find ways to integrate. As she became more comfortable with the online environment, she began to use technology constructively and chose tools such as VoiceThread which is an app where video, audio, and text are used to create projects.

During her observation, I noted that students had different technology devices they were using and I asked Sara about her school's and her policy concerning that. She explained that students are supposed to use the school computers, but she does not enforce that because it is a "battle that is not worth the effort" to restrict student use. She also stated that while she knew students were more engaged when she used technology in her lessons, she didn't think students wanted to use computers for every assignment. Specifically, Sara explained that her students 
don't like online textbooks and would "probably prefer to have a hard copy." She explained that problems with stable internet connections could lead students to not complete assignments and use that as an excuse. Later in the interview, she stated that she felt putting everything on the LMS gave students the excuse of no internet connection for not turning in homework, and she had no way to check if that was actually the case. In addition, there is no way for her to see exactly what her students are doing on their devices during her lessons and she cites this as a barrier for her technology integration practices during instruction. Sara also explained that her learning and using the technology tool is different than her students using it in the classroom. She stated that overcoming the student learning curve for effectively using technology tools can require too much time making it not worthwhile.

On her survey, Sara indicated that she had a high level of C-TPACK. I asked her to explain why she believed that. Because she has a high fluency using a multitude of technology tools, Sara explained that she is constantly reflecting about how she can find better ways to teach and present her materials. She stated that she used technology "almost every day in my classroom." She also explained that seeing other teachers and even pre-service teachers in her classroom modeling new technology tools with her content has motivated her to try. In addition, she knows that online environments provide access to more "authentic materials" such as clothing stores and restaurants where she can find resources to help students practice their vocabulary and conversational Spanish. Like Kate, Sara also believed it was necessary to think critically about those resources, but had not had coursework or PD in how to do so. She explained that critically analyzing resources was "still a challenge for me" and she found herself being "steered towards white male authors." 
Another critical component of her decision-making surrounding technology integration in her instructional practices was understanding the digital literacies and CDL of her students. This is what she had to say:

Vicki: If you use - if you choose like a technology integration tool - how do you come to those resources with a kind - kind of a critical theory perspective, or critical consideration?

Sara: Mm-hmm. Yeah, I think it would depend on the tool and what they're doing with it... one of the things that it's a little bit challenge more challenging, about making sure that the sources you have are representative. It is hard. So, for example, if I was going to have the students look at newspapers and they're gonna use some kind of internet or whatever to find those different articles, what - where is it they're getting them from? Who are they looking at? Are they all from one particular, um, country, or you know where is the diversity coming in there? So, that is something where I kind of have to guide the students to make sure that they are not, um, just looking for the first site that pops up. And being teenagers, that's the thing they do, whatever the first site is...because they don't where - what to look for. And then so that's where I have to start, um, you know pushing them a little bit to go past the very surface things

It has been challenging for her to make sure the sources she has are "representative." Later in the interview, Sara stated that the students "don't have those skills and are not thinking critically" about the resources they choose. When I interviewed Sara in May, she had not used the Weebly activity she spoke of above with her students, so while it provided an example of her incorporating CDL practices in the past, it was not reflective of her practice at the time of this study. 


\section{Valuing the modeling of and tying technology to content.}

Sara stated that learning about technology motivates her to use it in her classroom. Seeing technology used with her content area in her courses seemed to be that "purpose" she needs to drive her to integrate it. In fact, she has incorporated several of the things she learned in the Technology for Writing course such as VoiceThread and Weebly.

Knowing how challenging it has been for her to find reliable resources makes her worry about her students' being able to find and use resources. At the same time, she does see the value in students understanding how certain websites represent, under-represent, and over-represent different demographics of people. Sara has incorporated activities where students must find reliable and reputable resources to support their views. However, she explained that she has not received $\mathrm{PD}$ in teaching students that skill which has impacted her decisions about continuing to include those activities. She stated that the students "don't have those skills and are not thinking critically" about the resources they choose. However, she does see the value in using technology with her students in more interactive ways and hopes to do more of that in the future.

\section{Determining the role and level of technology use in the classroom.}

Throughout the interview, it was apparent that Sara had spent much time reflecting about when and how to most effectively use technology in her practices. The lesson and unit plans she provided me with in combination with my observations and her interview responses showed her technology use to be constructive in her planning which showed her transformative use of technology. They also showed her engaging in critical dimensions of her personal technology use. While the quiz and presentation primarily served a more didactic purpose during her instruction practices, it was still student-centered in that she clearly hoped to engage and expose 
students to the materials in new ways to help them develop a stronger understanding of the unit theme.

At several points during the interview, Sara stated that relying on traditional teaching methods, such as worksheets, can provide an easier and more direct way to teach materials. She stated that she regularly asks herself, "did the students learn more than if I had taught it in a more traditional way?" This places the responsibility on the technology tool to prove its benefit. She seemed to be looking at technology as having to be designed in a certain way rather than it being her responsibility to adapt it and create with it to serve her purposes. While this is a reflective approach to technology, it is not a reflexive use of it in her instructional practices. She often privileged the traditional teaching methods because she felt that they have proven they work for her and are always stable. In short, her Technological Pedagogical Knowledge (TPK) did not align with her Pedagogical Content Knowledge (PCK).

Sara had some education in critical theory during her graduate work. She explained that what she learned led her to consider who her resources were representing. In fact, she tried to introduce critical theory into a lesson about the different economic conditions and poverty levels in the countries where Spanish is spoken. However, when reflecting about that lesson, she stated that when she taught about social issues, identity, and ethnicities, and economics, "I start stepping on people's toes." Later she stated she constantly thought "how are you gonna bring that into class." She explained: "It's a dilemma...For me, as a Spanish teacher, because I want to teach some of the stuff, but then I also don't want to overly influence my students about how they should think about different things." Those reflections led her to focus on her presentations as the primary means for exposing students to diversity in her class. She stated, "I mean that's 
one thing I've focused on forever and ever and ever is that the pictures that I use in my

PowerPoints are all people from all different - types of backgrounds." She has been

very conscious of that and then making sure that I'm representing lots and lots and lots of different people. And I think the students here are pretty, um, like aware of that. I think they would - if it wasn't that way - if it weren't that way my students, they'd be like, "Why do you just - or why are you just showing all those white people?

These responses indicated that Sara was generally using her critical literacy, or desiring to use it, in her teaching practices; however, her experiences with students and their responses in combination with her worry about imposing her opinions and beliefs onto her students impacted her decisions about how she would incorporate critical theory into instruction. While she chose technology as her means for that incorporation in the lesson I observed, it was indirect and didactic as it was presented through the images and videos in her PowerPoint rather than through critically engaging in the online environment. These were missed opportunities for Sara to engage in the critical dimensions of technology during her instruction. Conversations with her students about the dominant discourses and power structures represented in digital tools and online environments could have decreased her worry about not knowing her students' CDL which could lead to a greater comfort level with engaging the students in the transformative and critical dimensions of technology.

\section{Conclusion}

The qualitative data findings presented above offered a multitude of insights about the processes the four teachers engaged in when making decisions about technology integration in their practices. Their personal uses of technology showed a high level of skill with a broad range of technology tools. All four teachers were highly educated and continued to seek further 
specific PD in technology use. However, the findings showed that while some of the teachers integrated technology in transformative and critical ways in their planning and preparations for the lessons, none of the teachers' instructional technology use reflected CDL practices. The following chapter provides an in depth discussion of the findings across all four teachers. 


\section{CHAPTER V1: DISCUSSION OF QUALITATIVE FINDINGS}

The purpose of this chapter is to provide a discussion of my understanding and interpretations of the findings from the qualitative data. As a result of First and Second Cycle

Coding, I identified themes across each individual's data sources. Here, I present a cross-case comparative analysis where I discuss the connections across the four teachers studied in Phase 2 based on those themes. This discussion addresses RQ2 and RQ3.

\section{Recruiting C-TPACK in Planning and Instruction}

Below, I present three themes I found that contributed to answering RQ2. First, I discuss my findings about the teachers' pedagogical beliefs and the ways those beliefs impacted both their recruitment of C-TPACK and their decisions about student technology use. Second, I discuss the missing "C" component of C-TPACK in the teachers' practices and provide my understanding about its absence based on my findings from data analysis. Third, I discuss how the teachers' reflective and reflexive practices contributed to their processes for recruiting CTPACK in their planning and instruction.

\section{Pedagogical Beliefs Reflected in Decisions}

When asked in the interviews about their pedagogical beliefs, Diane and Andrew called themselves Constructivists. Kate did not explicitly state that she was a constructivist; however her explanation of her approach to teaching and learning strongly reflected components of Constructivism. Sara also did not specifically claim a specific pedagogical stance. However, as explained in Chapter 5, she used both traditionalist and constructivist methods during her planning and teaching. Andrew was the only teacher who claimed critical theory to be integral to his pedagogical beliefs; still, all of the teachers explained that critical theory was important to 
their content areas and consequently to their practices. According the likert-scale and the openended survey answers, the four teachers all believed they had a high level of CDL and provided examples in writing and during the interviews of how they had recruited CDL to their technology integration teaching practices. Consequently, all believed they applied critical theory to their planning and instruction.

According to studies reviewed in the literature (Ertmer et al., 2012; Koehler \& Mishra, 2009; Liu, 2011; Overbay et al., 2010; Ruggiero \& Mong, 2015; Tondeur, et al., 2013), teachers' pedagogical beliefs strongly impact and are reflected in their instructional technology use. This was especially true of teachers with constructivist beliefs. This meant that if the teachers believed themselves to be Constructivists, their technology integration practices would most likely also reflect Constructivism. The analysis showed that in all of the teachers' lesson/unit plans, there were constructivist elements; however, few of the teachers' instructional practices in their classrooms reflected constructivism. The teachers' practices aligned more closely with what Montrieux, Vanderlinde, Schellens, and De Marez (2015) explained:

While it can be argued that the use of technology during classes can support constructivist approaches, implementing technology into classes does not imply a radical change of the didactics. Just because teachers are using technology, does not mean it's meaningful use. (p. 1)

While all four teachers stated that critical theory was valued and played a role in their planning, it was not connected to the ways in which they taught using technology in the lessons I observed. Andrew, who self-indicated critical theory and constructivist pedagogical beliefs, engaged in constructivist and critical dimensions of technology in his planning, but did not have students using technology in constructivist or critical ways. The same can be said for Diane and 
Sara. While Diane and Sara employed constructivist and, to some degree, CDL practices in their personal use of technology during planning, they did not extend an opportunity to their students for constructivist and critical uses of technology during the lesson. Instead, they relied on traditionalist teaching methods. Diane, Andrew and Sara's instructional uses of technology had a didactic function where their intent was to use their presentations for delivery of the materials. Kate's use of technology with her students did reflect constructivism, which aligned with her constructivist pedagogical leanings; however, in this subset, she was the exception and not the rule. At the same time, Kate did not recruit her CDL in her instructional practices resulting in an absence of the critical dimensions in her students' technology use. Consequently, these findings were not reflective of previous research.

These findings show that while the teachers strongly believed they had C-TPACK, they did not recruit C-TPACK into all of their practices. Their pedagogical beliefs may have been recruited when thinking about the different possibilities for student technology use, but during the lessons observed, they did not include CDL practices in their instruction. According to the literature, a teacher's pedagogical beliefs appeared to affect a teacher's interest to not just learn about, but actually implement technology in meaningful ways in the classroom. Studies showed that the level of integration was affected by whether a teacher more highly valued either a traditional or a constructivist approach to instruction (Ertmer et al., 2012; Koehler \& Mishra, 2009; Liu, 2011; Overbay, Patterson, Vasu, \& Grable, 2010; Ruggiero \& Mong, 2015; Tondeur, et al., 2013). That did not wholly apply in my study as the teachers' personal planning technology use reflected constructivism and to differing degrees, CDL, while their technology use with students was neither constructivist nor critical in all of the cases except Kate, who did use constructivist teaching practices with her students and technology. 
Koehler and Mishra (2009) believed that technology, pedagogy and content knowledge (TPACK) should be considered interdependent elements in all curriculum and PD. They stated: "Teaching successfully with technology requires continually creating, maintaining, and reestablishing a dynamic equilibrium among all components” (p.67). My addition of a critical component to TPACK included consideration of $\mathrm{CDL}$ in that dynamic equilibrium. The teachers all believed they had the critical component of C-TPACK; however, that was not the case.

\section{The Missing "C" in C-TPACK}

A principal finding in this study was that the "C" in C-TPACK was limited or missing in all four of the teachers' education and PD. It was missing in all four teachers' technology use with students; however, it showed up in their planning practices. All teachers indicated that they had exposure to critical theory in their coursework (in varying degrees), and it seemed that they were able to recruit that knowledge, to different extents, in their personal lesson planning practices involving technology. Only Andrew stated that he had a strong comfort level applying critical theory to technology in his practices, yet he did not engage in that critical dimension of online environments with his students. That may not be the result of lack of having learned and developed CDL, but could have been due to other barriers he cited (detailed in Chapter 5). During the interviews, when asked about barriers surrounding CDL practices, all four teachers stated that there was a lack of exposure in applying critical theory to technology during teacher education coursework and in PD offered by their schools. Diane said that she had not heard of CDL before, that she was not comfortable with her students' CDL, and that she didn't see a strong connection of CDL to her content area. In the interviews, only Kate stated that she had exposure to what she believed to be CDL, yet she did not recruit it in her instructional practices. 
While all teachers stated that some of the PD offered by their schools tied content to technology, none of the PD tied theory or pedagogical beliefs to technology. Importantly, for this study, was the specific absence of tying critical theory to technology integration practices. The teachers' evaluation and awareness of these absences did show they reflected about their recruitment and development of C-TPACK, which led each of them to pursue self-directed PD.

In the interviews, each teacher described examples of their self-directed PD. Kate created her own online PLN by joining online teacher communities and social media sites whose followers have interests similar to hers. Andrew became a Schoology Expert so he could create ways for his LMS to better serve his teaching needs and practices. Diane relied on the NGSS website and technology integration suggestions from the NASA and PBS Science websites. Sara took post-graduate courses to earn a certificate in the teaching of writing using technology integration. In none of the cases did the teachers say they sought out further education about tying theory in general, and critical theory specifically, to technology. Sara and Kate expressed that they needed help learning how to teach students about CDL practices but had not yet found that help. Andrew believed he already was tying critical theory to technology as he questioned all resources he used and looked for assumptions made and agendas pushed in all of the forms of media he used in his practices. Diane recognized that critical theory should be tied to technology but that it was "related to social studies more than science" and that CDL was "new to me."

All teachers were applying critical theory in varying degrees in their planning practices; however, none had their students engage in CDL practices during the lessons. This finding contributed to locating the missing critical component in their C-TPACK. Based on the literature, teacher coursework and PD were found to be the optimal contexts to connect critical theory to technology practices in instruction (Avila \& Pandya, 2013; Song, 2016; Watulak \& 
Kinzer, 2013). Changes to foundational beliefs through observation and hands-on practice combined with critical reflection lead to technology integration practices that contain critical dimensions (Kim et al., 2013; Ertmer et al., 2012; Liu et al., 2015).

Research has shown that PLCs, communities of practice, modeling, coaching, and mentoring that is centered on meaningful technology integration leads to meaningful and critical technology integration practices (Atkins et al., 2010; Battersby \& Verdi, 2015; DuFour \& Mattos, 2013; Kopcha, 2012; Liu et al., 2015; Louis \& Wahlstrom, 2011). While these forms of PD were present in the teachers' experiences, the focus of that PD did not center on critical theoretical components of technology integration. In all four cases, the teachers explained that the PD they received consisted of short workshops that largely focused on the latest technology tool available and served to meet the goals of the school rather than the specific needs of the teachers. Without knowing or learning about the critical dimensions of technology through study and practice in applying critical theory to digital environments, recruitment of the " $\mathrm{C}$ " in $\mathrm{C}$ TPACK is impacted (Ertmer et al., 2012; Koh et al., 2014; Overbay, et al., 2010; Prestridge, 2017; Ruggiero \& Mong, 2015).

\section{Reflective and Reflexive Technology Integration Teaching Practices}

It was evident in both their planning and instructional practices using technology that all four teachers were not only highly skilled in a multitude of technology tools, they were also continually reflective about their technology use. This constant reflection revealed their recruitment of C-TPACK to determine how and when technology fit into their practices. The teachers' reflective practices centered on several things. First, as discussed earlier, their constructivist inclinations led them to reflect about how best to engage students using technology to enhance their teaching. They sought out PD to help them more thoroughly integrate 
technology into their planning, presenting, and developing of student activities. At the same time, they continually reflected about the contexts in which their students would be using technology. This included an awareness about the needs of their students (such as students' interest in technology) and their students' digital and critical digital literacies. They also reflected about their struggle to develop their own CDL practices and how underdeveloped personal and student CDL impacted their technology use with students in different ways.

In the interviews, the teachers were asked about their inclusion of CDL in their teaching. While each teacher believed they engaged in CDL practices in their planning (i.e. Kate stated she recognized that students needed to learn how to represent their beliefs and interests in online environments), Diane and Sara were unsure about incorporating those practices with student technology use, and expressed the most trepidation about engaging students critically in online environments. Neither had confidence that their students had the skill set to identify and evaluate relevant and reliable sources and resources. In fact, Sara explained that she, herself, struggled with finding reputable resources and that her struggle informed her decisions.

While both Sara and Diane recruited their C-TPACK to engage in CDL practices during planning and creating their presentations for their lessons, they decided to provide the resources they found to their students rather than have students locate them themselves. Their decisions to control student use of technology showed that they recruited their C-TPACK when they determined what student knowledge was needed to effectively, and in Diane's words "appropriately," operate in the online environment.

During their lessons, Kate and Andrew's instructional technology practices were reflexive and aptly described by Kate as being "comfortable with the uncomfortability of technology." The ease of their recruitment of their TCK was evident. Specifically, Kate's 
openness to students engaging in online environments during her lessons revealed a willingness to engage in technology use without knowing the outcome. In addition, Kate's interactions with regard to her students' technology choices and uses were reflexive. She easily and readily suggested a great variety of technology tools that she believed reflected her students' various fluencies with technology. Kate did express her struggle to identify reliable resources and how to teach that process to her students and, as explained earlier, the critical component was absent in her instructional use of technology with her students. She stated she knew that many teachers at her school struggled with the same thing. However, during the interview, she explained that part of her process for planning was to expose herself and her students to new technology tools. She stated she was trying to be more "explicit" in her teaching by showing students her process for finding reliable resources. In that way, she saw her role as developing students' CDL and modeling that practice for them. Her understanding of CDL was different from how CDL was defined in this study as she kept referring to finding reliable resources as a CDL practice. She did not consistently address the social and political structures and dominant discourses found in online platforms.

Andrew's pedagogical beliefs reflected critical theory and constructivism. He also had a very strong personal interest in technology. His interests and beliefs together led to CDL practices in his planning that were not just reflective, but also reflexive. He explained that he questioned people's agendas in every resource he included in his planning and instruction, including technology tools and online resources. In his virtual classroom, he provided URQs and multiple opportunities for students to explore and engage in the materials. He was open to an assortment of assessment options to meet the diverse needs of his students which showed much flexibility. As evidenced in his lesson, it was natural for him to connect critical theory to digital 
environments in his personal use, despite the fact that he did not have students explore that connection for themselves.

While all four teachers were reflective and reflexive in their personal technology use during planning and preparing for their lessons, only Andrew and Kate were reflexive in both their planning and instruction practices regarding student technology use in the lessons I observed. Andrew alone was reflexive in his personal application of critical theory to technology practices. Reflexive practices support the consideration of the contexts within digital environments by allowing room for a critical look at the power and ideologies at work as students learn in technologically integrated spaces. Being reflexive with technology tools and resources can lead teachers to more transformative and meaningful technology integration practices (Montrieux \& Schellens, 2018). Montrieux et al. (2015) explained that

Learning with technology needs more than making learning activities digital, it is also about creating contexts for authentic learning that use new technologies in integrated and meaningful ways to enhance the production of knowledge and the communication and dissemination of ideas. (p. 2)

This requires modeling and practice. Moving from teacher-centered technology use to studentcentered requires continuous PD focused on pedagogy and technology use (Montrieux \& Schellens, 2018). Without such PD, teachers often find themselves balancing teacher- and student-centered technology practices until a teacher's comfort level with technology use in the classroom increases (Montrieux \& Schellens, 2018).

Ertmer and Otten-Leftwich (2013) explained "Although most teachers have shifted away from implementing classroom activities designed for students to learn about technology, students in today's classrooms still tend to learn from technology, using it primarily as a delivery tool" ( $\mathrm{p}$. 
175). It was evident that Sara and Diane were learning from their reflective practices, but in their lessons and from their interview responses, they were not comfortable using technology with students in a reflexive way. While Kate expressed her concern and struggle in her own CDL practices and that the "C" of C-TPACK was missing in her recruitment, this did not prevent her from being reflexive in her practices surrounding student technology use and online engagement during her lesson. As explained earlier, Andrew was both reflective and reflexive with his and his students' technology use in his lesson and did not express concerns about those decisions.

\section{Factors Impacting Teachers' Engagement}

Below, I present three themes I found that contributed to answering RQ3. First, I discuss my finding that the limited exposure to C-TPACK in teacher education coursework and PD was considered a barrier by the teachers. Second, I address the uncertainty about students' critical digital literacies, which contributed to traditionalist and didactic practices of the teachers. Next, I discuss the teachers' understandings of critical theory as applied to technology integration. Finally, I discuss the teachers' strong personal technology skillsets, constructivist pedagogical beliefs, and how connecting standards to lessons positively impacted teacher technology integration in their planning.

\section{Limited of Exposure to C-TPACK}

Each of the four teachers explained that they had limited exposure to and modeling of CDL and of tying pedagogy and theory to technology use in the classroom in education coursework and in PD offered by their schools. On their surveys, Diane and Andrew said they had not heard about CDL in their coursework and had not seen instructors model it. Sara and Kate said they had heard of it and had seen it modeled by instructors, however they clarified in their interviews that their exposure was very limited. In Kate's case, what she experienced in her 
course was not called CDL but that was what she thinks it may have been. On their surveys, in response to the statement "I continually plan to incorporate critical digital literacy into my lesson planning and instruction," Kate and Diane responded "neither," and Diane and Andrew responded "disagree." This lack of both development opportunities and exposure impacted these teachers' decisions in different ways.

\section{Education coursework.}

Only in Kate's case was CDL introduced in her graduate educational technology course. However, Kate did not connect what she experienced in those two courses to CDL until after she took my survey and "googled" it which led her to "refine" her understanding about critical theory in digital environments. The teachers' awareness and concern about this lack of exposure through coursework and/or PD did factor into decisions the teachers made in their lesson planning and instruction practices. Kate reflected that she struggled in her own technology use with applying critical theory to her practices. Andrew's pedagogical beliefs are both constructivist and critical theory based. Consequently, regardless of the absence of CDL in PD from his school and education coursework, his inclination was to always "recognize that bias is there" and to "question what you see and the assumptions." Andrew did provide a secured and controlled LMS platform for his students to individually, not collaboratively, examine their personal beliefs and connections to the materials in their own time the night before his lesson; however, when using technology with his students during the lesson, Andrew did not have them critically engage in the online environment.

Diane and Sara dealt with the absence and lack of CDL exposure and development opportunities differently. Diane stated that CDL is a "contemporary issue because we haven't had to address or acknowledge it before." She explained that this study was the first she had 
thought specifically about how critical theory plays a role in digital environments. It was clear from her interview that while she recognized that CDL was necessary for students to find "appropriate" resources, she was not confident in their ability to do so. As such, she chose to didactically use her presentation and strongly control the students' use of technology during her lesson. Sara continually recruited her own C-TPACK and engaged in CDL practices when developing the unit on beauty perspectives. The nature of the essential questions from that unit invited critical theory. However, like Diane, her presentation served a didactic function and she chose not to have her students critically engage online.

\section{Professional development.}

While all teachers sought out their own PD with regard to tying content to technology, they did not state that they sought out PD in tying critical pedagogy and/or theory to technology. At all schools, the teachers were required to earn PD hours, which they reflected about in their interviews. Kate and Sara described their schools’ PD as strongly encouraging technology integration practices through the use of new technology tools. Kate, Sara, and Andrew described the PD they received from their schools as short tutorials about new technology tools. Andrew, Kate, and Sara believed their schools' technology PD was based on the needs of the district rather than on the needs of the teachers. Diane stated that the PD regarding technology at her school was limited to "maybe one afternoon" a year. Kate and Sara stated they needed additional

PD to develop their own CDL. This absence in their PD of tying critical theory to technology had an impact on each teacher's planning and practices.

This missing critical component in teacher development opportunities showed in their stated concerns about their students' CDLs, which then impacted their instructional decisions surrounding technology use with students. Kate and Sara struggled with finding ways to develop 
their students' CDL which hindered their incorporation of more critical and meaningful technology use with their students. In Diane's case, she did not trust that her students had CDL skills and in her lesson she chose to avoid and control her students' exposure to online situations requiring such skills which reflected protectionist practices (Burnett \& Merchant, 2011). Andrew wanted to expose his students to more meaningful online experiences but he claimed school restrictions and resource limitations were barriers for him. (Those barriers are discussed in detail below.) He also highly valued his role as Schoology Expert and Ambassador. As such, he was used to occupying the role of expert in technology use and he continued that during his lesson.

The teaching practices of Sara, Diane, and Andrew surrounding technology use placed them in the role of expert during their lessons. All three teachers controlled the use of technology during instruction and the students' use of technology during classroom activities. Their presentations were used to give students the content and to provide their personal understandings of the materials and resources presented. Avila and Pandya (2013) address this teaching approach with regard to incorporating CDL practices into a teacher's instruction:

Part of the wariness comes, we suspect, from the fact that teachers and learners are likely to undergo role transformations while implementing critical digital literacies. The disruption of authority, and fluidity of the relationship between learners and teachers (or novices and experts), can unnerve those who usually see themselves as 'experts.' (p. 6) These transformations entail "not just letting students teach us, or each other, in isolated instances, but encouraging them to forge their own paths to authority so that there's room for multiple paths to knowledge" (Avila \& Pandya, 2013, p. 6; Avila, 2008; Merchant, 2009). Without PD opportunities to develop their own CDL, it seemed that the teachers were more 
comfortable staying in the role of expert. As stated earlier, only Kate had some exposure to CDL in graduate coursework resulting in her consciously taking herself out of the role of expert in an effort to remain student-centered in her technology use with students. She stated that her selfdirected PD, where she continually engaged in educational online communities, showed her the benefit of doing so.

\section{Uncertainty About Students' Critical Digital Literacies}

All of the teachers recognized the importance of technology in their students' lives. They all stated that including technology in their lessons resulted in engaged students. Yet, in the lessons that I observed, all four teachers chose not to provide opportunities to their students to engage in transformative uses of technology where students could engage in the critical dimensions of online environments. The lack of coursework and PD discussed above could have contributed to both the teachers being uncertain about their students' CDLs and the teachers not including those critical dimensions during their lessons.

When asked about incorporating CDL practices in their teaching, Sara, Diane, and Kate explained they were unsure if students had CDL skills. Andrew expressed confidence that he had taught his students CDL practices through his modeling. Sara expressed her concern that exposing students controversial topics in online environments could be seen as pushing her opinions on students. This aligns with what Burnett and Merchant (2011) explained:

The stakes are undeniably higher still when we use learners' interests as a way of introducing critical engagement. Buckingham (2003) summarized this when he described how critical media studies can easily result in "spoiling" the enjoyment of popular texts and inculcating particular "correct" or "worthy" readings, often with variable results. (p. 
Diane worried that if students had freedom within online environments during her lessons, they would "go on something that is not appropriate for them." Both Sara and Diane's worry led them to use technology in the lessons in a controlled, didactic, and substitutive way. Kate stated that not knowing what her students were doing online outside of the classroom made it more important for her to teach and model CDL practices so her students could "stand up for themselves and represent themselves" in those online environments; yet she did not provide that opportunity to them during her lesson. Her concern led her to provide an abundance of tools to her students so they could choose which medium to represent their passions with. That provision did not come with discussion about the social, cultural, and historical structures, powers, and discourses operating in the online environments in which the students would be engaging. She stated that:

I feel like that's a very challenging thing to teach. And teaching students how to, kind of, not just take what they are given for what it is. Really dig deep into the why. Why would they say this? What do they have to gain from this? It's really difficult to teach that, I think.

While Andrew believed that his students had been exposed to online environments enough to have developed CDL to a certain extent, he did not engage in the critical dimensions of technology use during his lesson. This appears to be reflective of other barriers such as resource limitations (discussed below) rather than an uncertainty about his students' CDLs. Providing students with such opportunities allows them to "draw on their cultural resources and life experiences as they deconstructed, debated, resisted, and reimagined dominant narratives of urban students" (Gainer, 2010, p. 372). Gainer (2010) emphasized the importance of the teacher's role in facilitating such practices. This requires an understanding of youth culture and 
engagements with the digital environments in which they continually operate (Gainer, 2010).

Such engagement was limited at best for these teachers and could be attributed to their uncertainty of their students' CDL.

\section{Teachers' Understanding of Critical Theory}

While only Kate had coursework in CDL, all four teachers did have exposure to and coursework in critical theory. However, their explanations of critical theory as applied to technology use varied from teacher to teacher. Kate believed that by providing her students with a multitude of choices of technology tools to use for their projects, she was engaging in critical dimensions with technology. While this showed her being reflective and aware that those tools offered diverse ways for students to represent themselves and their interests, she didn't engage in the social, cultural, and historical contexts and power structures operating within online environments. Interestingly, her school is strongly supportive of technology integration for teachers, they provide access to technology specialists who is "able to assist" and she can "request to have a one-on-one meeting to talk through what we're trying to incorporate." Yet, she explained her struggle to learn how to develop students CDL and need for more education about connecting critical theory to online environments. Her school seemed to be providing the resources to help her, but she did not see those resources as a means to help her with tying critical theory to technology.

Based on analysis of her practices and her explanation of her understanding of critical theory as it applied to her technology use, Diane's practices did not reflect C-TPACK, rather they reflected TPACK. She evaluated resources, which is considered just one component of CDL, however, the other three components were absent which led to substitutive use of 
technology. She believed that critical theory applied more to social studies than science. When asked about her knowledge of CDL, she said it was "new to her."

It was clear from Andrew's interview that he had a strong understanding of applying critical theory to his content. He extended that theory to his personal technology integration practices, which resulted in the presentation he used in his lesson. He stated that he constantly reflected about the intentions and purpose of technology tools. He explained that before he used digital resources, he critically analyzed them to determine whose perspective they represented. He made sure to note the contexts in which resources were created. Andrew also critically analyzed the tools themselves to ensure they were not just substitutive before he integrated them into his planning and instruction. Interestingly, he used technology in his lesson in a substitutive way. Based on analysis of his planning and presentation, he engaged in all four components of CDL in his personal technology use during his preparation for his lesson (Watulak \& Kinzer, 2013). In that way, his planning practices showed his transformative and critical use of online environments. However, that was not the case with his technology use during this lesson.

Andrew did provide an explanation of a lesson where this was the case which showed recruitment of C-TPACK. During a recent unit, he explained that used his LMS to provide students with various Bills of Rights, broke them into groups, and asked them to find and use primary resources to compare the social, cultural and historical contexts during which each was written and enacted. They had to discuss how different sectors of the population were impacted by those documents. Students then presented their findings to the class. This activity reflected Andrew using technology during instruction in transformative (Puentedura, 2003), meaningful (Paratore et al., 2016), and critical (Watulak \& Kinzer, 2013) ways. 
While Sara's personal technology use included critical analysis and reflection about the online resources she used, that was not the case in the activities for student technology use in the lesson I observed. Her explanation of her Weebly assignment for her students that was provided in Chapter 5 showed that she did have a strong understanding of the power structures at work in online environments. In fact, in the past, she had used the Weebly assignment to connect critical theory to her content and materials. However, in her interview, her focus was on the resource barriers that seemed to prevent her from engaging in those critical dimension of student technology use. Those resource barriers are discussed below and contribute to answering RQ3.

\section{Resource Limitations and School Policies}

Andrew believed that the restrictions his school imposed on the use of community online platforms made his students less likely to engage openly and honestly in online discussions designed to help students develop, support, and represent their personal views and opinions about course materials. Kellner and Share (2007) warned against what they called a "protectionist approach" where educators and administrators restrict student and social media use to the point that true opportunities for critical discourse and meaningful collaboration becomes unattainable. In fact, restricting texts works against the premise of multiliteracies and the inclusion of multiple avenues for literacy practices to reach all students (New London Group, 1996).

Diane was neither negative nor positive about the restrictions her school imposed. It seemed that those restrictions supported or could have led to her assumption that her students did not have CDL, resulting in her not engaging in CDL practices with her students. Sara explained that her school eliminated Spyware, a software that allows teachers to see each student is doing online, due to licensing costs. Not being able to see what the students were working on when 
online made her less likely to have them be online during class activities. This not only reflected her wanting to control students' technology use, it reflected her not wanting to have students critically engage in those environments, removing opportunities for students' to develop their CDL.

Andrew stated that his school eliminated software he was using for projects that did engage students in the critical dimensions of technology. In addition, his school monitored all students' discussions online using what he called a "lockdown" method where they track each student's comments to ensure no cyberbullying takes place. He believed that policy worked against students learning how to develop respectful online practices because the it made students stop commenting altogether. Kate did not feel restricted by her school's policies, rather she believed her school supported and encouraged teachers integrating technology. However, she stated it would be "amazing" if her school could provide PD that connected critical theory to technology, highlighting a noted absence that impacted her CDL practices in instruction.

All four teachers mentioned that moving beyond substitutive technology use with students to transformatively and critically integrate technology required considerable time and effort that posed a barrier for them. Sara pointed out that her students' learning curve for critically and effectively operating in online environments was a barrier. She also explained that technology can be distracting for her students and, managing that distraction takes time away from focusing on the course materials. Sara stated that while there are "more things I could do" with student technology use, she always asked the question "is it worth it?"

Kate felt that the amount of time it took to use technology with students and to teach them new tools played a large factor in whether and how she had students use technology during her lessons. Andrew explained that he constantly wished he had more time to implement 
technology in newer and more meaningful ways. That was one of the reasons he chose the flipped classroom model which he believed provided his students with more technology opportunities that he did not have time for during class. Diane explained that some of her students do not have WiFi access outside of school. Any activities with students using technology had to take place during classroom time. This posed a barrier as there was not enough time during a class period to dedicate to bigger technology projects such as completing a virtual lab.

\section{Technology Skill Sets, Constructivist Beliefs, and Connecting Standards}

The findings showed several ways the teachers' engagement in the critical dimensions in their teaching practices were and/or could be supported. These included: the teachers' strong personal technology skill sets, constructivist pedagogical beliefs, and how connecting standards to lessons positively impacted teacher technology integration in their planning.

\section{Strong personal technology skill sets.}

The four teachers all believed that they did engage in the critical dimensions of technology use according to their personal understandings of CDL. As explained in Chapter 5, it was evident in the findings that this was not the case according to the way that CDL and CTPACK were defined in this study which was provided to them. Regardless, all four teachers stated several supporting factors that contributed to their technology use and their perceived engagement in the critical dimensions of technology use during instruction which are important to discuss as they could potentially lead to inclusion CDL practices.

Research has shown that having foundational technology skills and a comfort level using technology can lead to more meaningful technology integration. The longer and more intensively teachers use technology leads to more student-centered practices with technology (Montrieux, \& 
Schellens, 2018). In fact, all four teachers stated they used technology every day in their teaching practices. Both Diane and Kate specifically used the word "comfortable" when describing their use of technology. However, it was clear from my observations that the ways the teachers felt comfortable in their use of technology varied greatly when applied to engaging their students with technology.

In addition, studies have shown that when teachers connect their content and technology, they are more likely to integrate technology in meaningful ways. Emphasizing content area technology integration in coursework led graduate students to consider themselves as effectively utilizing technology (Paratore, et al., 2016). When teachers were able to see that connection of content, their pedagogical beliefs, and technology, they were more likely to regularly and meaningfully integrate technology in their lessons (Harris \& Hofer, 2014, 2017; Koehler \& Mishra, 2009; Niess, 2011). These teachers each sought out additional PD that tied content to technology and their advanced technology skills represented in the presentations, and in Andrew's case his virtual classroom, reflected those skills and knowledge.

In the products they created for presenting content and materials to their students, all four teachers showed that they were highly skilled in a multitude of technology tools on several online platforms. Andrew and Sara presented materials using their LMS and a diversity of technology tools and resources. Kate displayed her adeptness and knowledge with multiple technology tools and platforms during her conferencing with students. During her lesson, Diane's presentation reflected her ability to transform the course materials using embedded videos, and primary resources to connect Newton's Laws to a variety of settings and scenarios.

When asked about the primary drivers of their decisions to integrate technology into their lessons, Andrew and Kate stated they used technology to enhance their lessons and content and 
to reinforce materials they covered. Diane stated that she believed students watching an embedded video in her presentation "can also be considered direct instruction." Sara explained that while she "feels like I use a lot of PowerPoint and so I try to break out of the PowerPoint trap, sometimes PowerPoint is just the best." While her PowerPoint presentation in the lesson I observed showed her ability to critically analyze resources and transform her materials by presenting them in a variety of ways, her instructional use of her presentation was didactic. In short, for all of the teachers, those understandings and beliefs about the role of technology in instruction practices were substitutive (Puentedura, 2006), and were missing the CDL component. Importantly, their personal technology skill sets support potential to move further on the continuum towards meaningful, critical and transformative technology use. However, the barriers discussed above appeared to supersede that.

\section{Constructivist pedagogical beliefs.}

As mentioned in detail above in answer to RQ2, Andrew and Diane were self-professed Constructivists. For Kate and Sara, analysis of their data showed some of their practices and methods aligned with constructivist commentaries. High level technology skill sets coupled with constructivist pedagogical beliefs and practices have been shown to lead to more transformative and meaningful technology integration (Anderson \& Maninger, 2007; Chen, 2008; Ertmer, 2005). As studies about this were already presented in the RQ2 discussion above, repeating those

findings here is unnecessary. Research has shown that Constructivists are most likely to integrate technology meaningfully, transformatively, and critically (Ertmer et al., 2012; Koehler \& Mishra, 2009; Liu, 2011; Overbay et al., 2010; Ruggiero \& Mong, 2015; Sang et al., 2010; Tondeur, et al., 2013) and it is important to point out that all four teachers' planning practices reflected constructivism (Bhattacharjee, 2015; Dewey, 1938; Terwel, 1999). While not all 
teachers used constructivist activities during instruction, they believed those beliefs helped them see the value in integrating technology. In this study, their constructivist leanings did not lead the teachers to recruit C-TPACK to their instructional technology use.

\section{Connecting standards to lessons.}

Kate and Diane specifically spoke about the importance they placed on using the standards to guide their practices. Those standards support the integration of technology and in some cases, the inclusion of the critical dimensions of technology is supported. Diane used the NGSS to guide the development of her curriculum and the creation of her lesson plans.

Evaluation of those standards aligned with what Diane stated in her interview, that "I think it's vital to, um, to, I, I would say implementing the next generation science standards appropriately." Kate also strongly valued the standards in her teaching practices. In her lesson plan she stated "This section, Language Arts, is devoted to instruction directly linked to writing and state standards associated with writing." The state standards that Kate cited for this lesson included technology integration. Her thought process is reflected here:

I guess I look to - first to the standards that I'm teaching and if - and I guess also, time is a huge factor in that too. Is this gonna make it faster or is it - is it too much of a hassle to get out a computer, try to go to this website, teach them how to use the website. So, time and connectedness to the standard, I guess.

Andrew included an extensive list of standards on his lesson plan, and after observing him, he seemed to meet most of the standards he cited. While there was no technology component in those standards, they emphasized critically analyzing resources and documents. That, coupled with Andrew's pedagogical beliefs of constructivism and critical theory as well as his obvious advanced technology skill level, showed a missed opportunity to have students 
engage in the critical dimensions of technology for that lesson. Sara did not cite standards in her lesson and unit plans; however her lesson centered on critical theory concepts found in the AP College Board's curriculum that she relied on. In that curriculum, there is one unit called "Science and Technology" that focuses on critical evaluation and use of technology and developing an understanding of the "effects of technology on self and society" (Retrieved from https://apstudent.collegeboard.org/apcourse/ap-spanish-language/course-details\#/ )

Three of the four teachers specifically referred to the standards that applied to their content areas within their lesson and unit plans. The fourth teacher, Sara, indirectly applied the standards as she used the AP College Board's lesson which adheres to specific standards. As more educators are being required to demonstrate both teacher and student proficiency with technology according to standards set forth in the Common Core (National Governors Association Center for Best Practices, Council of Chief State School Officers, 2010), this was not surprising. Educators are finding themselves in a time of high-stakes accountability where the education system is being shaped by standards that include technology integration (DarlingHammond, 2012; Hofer \& Grandgenett, 2012; Kozma, 2011; Niess, 2011). This is considered to be the result of an increase in interest, internet access, and use by students, and expectations about technology integration by teachers in state and federal educational standards (Ball \& Forzani, 2011; Chen, 2010; Conley, 2011).

Overall, it was apparent that the teachers each gave consideration to the standards as they cited them in their lesson plans. The standards cited supported the use of technology in Kate, Diane, and Sara's cases; however, those standards do not include engaging in the CDL practices specifically. Upon review of those standards, their lesson plans, and their teaching practices during their lessons, it was clear that the standards guided and supported the teachers planning 
and instructional technology use. It was also clear that their not engaging in the critical dimensions of that use reflected the same absence of those dimensions in those standards.

\section{Summary}

This chapter provided an opportunity to discuss interpretations based on my findings from the analyses of each individual teacher's data. In addition, I presented my discussion of my cross-case comparative analysis of the four teachers. The findings, my interpretations of those findings and my discussion led to answers to RQ2 and RQ3. In the next chapter, I provide my conclusions that were informed by Chapters 4, 5, and 6 . 


\section{CHAPTER VII: CONCLUSION}

This chapter provides the conclusions that I drew from this mixed-methods study. This study was conducted in two parts: Phase 1 and Phase 2. In Phase 1, I utilized a survey containing both likert-scale and open-ended questions to identify graduate students who both believed they had a high level of C-TPACK knowledge, and who were practicing teachers. Those students were recruited to participate in Phase 2 of the study which resulted in a subset consisting of four

practicing teachers, two of whom taught middle school and two high school. Phase 2 consisted of collecting and analyzing data from teachers' lesson plans, observations of those lessons, and interviews. The result of that analysis led to answers of my research questions, which were:

RQ1: What is the critical, technological, pedagogical and content area knowledge of graduate students in one university's School of Teaching and Learning?

RQ2: How does a subset of these graduate students who are also practicing teachers recruit their C-TPACK into their planning and instruction (i.e. their practices)?

RQ3: What does this same subset of graduate students/practicing teachers identify as the contributing factors that supported or hindered their abilities to engage the critical dimensions into their teaching?

Here, I explain the implications for practice and for research that my findings and discussion about the data have led me to. First, I provide a brief summary about the answers to each of the three research questions. From there, I explain the limitations I believe my study had. Then, I discuss the implications that this study has for practice and for future research. 


\section{Summary of Findings}

\section{Research Question 1}

After analysis of the Phase 1 participants' surveys, I identified my subset of teachers for Phase 2. Analysis of the teachers' survey responses gave me a starting point from which to compare their beliefs with their practices (as observed) and interview responses, which when used in combination with the other data sources led me to a stronger understanding of how the teachers recruited their C-TPACK into their teaching practices.

\section{Research Question 2}

The combined analysis of data sources for each teacher using First and Second Cycle coding and constant comparative analysis across the data sources resulted in the findings that were discussed in Chapter 5. Those themes and categories were used again in the cross-case comparative analysis of the Phase 2 subset resulting in interpretations and discussion that contributed to answering RQ2.

Chapter 6 provided my discussion about my findings regarding RQ2. I learned that several factors contributed to the teachers' recruitment of their C-TPACK in their teaching practices. First, I found that while the teachers strongly believed they had C-TPACK, they did not recruit it into all of their practices. Their pedagogical beliefs may have been recruited when thinking about the possibilities of different student technology use, but they did not include CDL practices in their instruction during the lessons observed.

Another finding was that the "C" in C-TPACK was missing in all four of the teachers" coursework, PD, and technology use with students; however, it showed up in their planning practices. All teachers indicated that they had exposure to critical theory in their coursework (in varying degrees) and it seemed that they were able to recruit that knowledge, to different extents, 
into their personal lesson planning practices involving technology. However, all four stated there was a lack of exposure in applying critical theory to technology during teacher education coursework and in PD offered by their schools. This missing critical component was a factor in the teachers' recruitment or lack thereof of C-TPACK. Without knowing or learning about the critical dimensions of technology through study and practice in applying critical theory to digital environments, recruitment of the "C" in C-TPACK was not always possible.

An additional finding contributing to answering RQ2 was found in the reflective and reflexive technology integration teaching practices of the teachers. The study showed that in both their planning and instructional practices using technology, all four teachers were not only highly skilled in a multitude of technology tools, they were also continually reflective about their technology use. This constant reflection revealed their recruitment of C-TPACK to determine how and when technology fit into their practices. Their reflective practices demonstrated that they considered the contexts in which their students would be using technology. This also included an awareness about the needs of their students (such as students' interest in technology) and their students' digital and critical digital literacies. Finally, they reflected about their struggle to develop their own CDL practices and how underdeveloped personal and student CDL impacted their technology use with students in different ways. In all cases, that reflection led the teachers to seek self-directed PD. However, according to their interview responses, that PD was largely focused on tying their content to technology rather than critical theory to technology.

The ways in which the teachers were or were not reflective and/or reflexive factored in to how they recruited their C-TPACK to their practices. While all teachers were reflective, only Andrew and Kate were reflexive in their instructional technology practices, and only Andrew's reflexivity included consideration of the critical dimensions of technology use. However, his 
reflexivity in combination with applying critical theory to technology was only present in his personal technology use and did not extend to student instructional practices with technology.

\section{Research Question 3}

The process I used to gain insights about the teachers' practices in RQ2 was also used in answering RQ3. The combined analysis of data sources for each teacher using First and Second Cycle coding and constant comparative analysis across the data sources resulted in the findings that I discussed in Chapter 5. I constantly reflected on those themes and categories again in the cross-case comparative analysis of the Phase 2 subset, which resulted in interpretations and discussion that contributed to answering RQ3.

\section{Barriers for engaging in critical dimensions of technology integration practices.}

While all four teachers indicated on their surveys that they believed they had the knowledge to do so, none of them engaged in the critical dimensions of technology use with students. It was clear from their responses in the interviews that Kate and Diane's understanding of applying critical theory to digital environments did not reflect the explanation of CDL and the C-TPACK knowledge domain provided during their survey and at the interviews. In fact, neither engaged in the critical dimensions of students' technology use. Based on their interview responses, it was evident that Andrew and Sara's understanding of CDL and C-TPACK reflected the way I defined them in the survey. However, C-TPACK was only present in their planning practices and not in their instructional practices with student technology use. My analysis of the data showed there were several factors that served to either hindered or supported their abilities to engage in the critical dimensions in their teaching. 


\section{Factors considered barriers.}

One factor that hindered their abilities to engage the critical dimensions was a limited exposure to C-TPACK in teacher education coursework and PD. Their survey and interview responses in combination with observations, reflected previous studies that emphasized the importance of exposure to instructors who are modeling technology integration practices. That exposure led to more transformative and critical use in the teachers' practices (Burnett \& Merchant, 2011; Kellner \& Share, 2007; Montrieux \& Schellens, 2018; Montrieux et al., 2015; Puentedura, 2003; Serafini, 2012). Another factor considered a barrier was the PD offered at their schools. They all stated that the schools' PD programs did not expose them to modeling of C-TPACK. Professional development opportunities provided by their schools focused on tying content to technology versus pedagogical beliefs and critical theory to technology.

As explained in Chapter 6, Andrew cited resources as a strong barrier preventing his inclusion of activities where CDL could have occurred in his instructional practices (See "Resource limitations and school policies" below). Nonetheless, it remains that he believed he had the knowledge, but chose not to incorporate critical dimensions in his technology use with students.

The teachers' understandings of CDL were considered a barrier for engaging the critical dimensions as well. Only Kate had coursework in CDL; however, all four teachers did have exposure to and coursework in critical theory. Regardless, their explanations of critical theory as applied to technology use varied from teacher to teacher. In addition, in all cases, the teachers did not include critical dimensions in their instructional practices. Each recruited C-TPACK differently depending on their exposure and PD regarding CDL, and on the contexts of their 
classrooms. Included in those contexts are resource limitations and school policies which played a factor in the teachers' engagement in the critical dimensions of technology integration.

Resource limitations and restrictive school policies surrounding online environments were considered hindrances for the teachers. All four teachers mentioned that moving beyond substitutive technology use with students to transformatively and critically integrating technology required considerable time and effort which impacted their technology integration decisions. All sought PD regarding tying technology to content outside of the PD opportunities offered to them, and that knowledge gained was reflected in their positive survey answers regarding TCK.

The schools' policies and restrictions regarding online practices of students and teachers proved to be a hindrance for engaging in the critical dimensions of technology integration practices for Andrew and Sara. For Diane, these limitations and restrictions seemed to reflect her own understanding of the role that critical theory played in her technology integration practices with students and as such, they supported her assumptions about her students' CDL.

This limiting of resources for teachers and restricting of students' online access and use reflect a protectionist approach to student technology use. Researchers describe restrictive internet policies within schools as potential barriers and state such protection may not be necessary (boyd, 2007; Burnett \& Merchant, 2011; Kellner \& Share, 2007). Burnett and Merchant (2011) supported CDL practices as a means of preventing passive consumerism and social stereotyping or misrepresentations of people, cultures, and/or beliefs as it arms students with a critical perspective that "...could be used to interrogate the competing discourses which surround social media use - around positive stories of participation and empowerment on one hand and more negative associations with consumerism, exploitation, fraud, safety and so 
forth..." (p. 44). A protectionist approach can result in loss of true opportunities for critical discourse and meaningful collaboration (Kellner \& Share, 2007).

\section{Factors that supported engaging in critical dimensions of technology integration}

\section{practices.}

There were several factors that supported the teachers' engagement in the critical dimensions of their planning and instruction with technology. These included: the teachers' strong technology skill sets; constructivist pedagogical beliefs, and connecting standards to their lessons.

Strong personal technology skill sets were considered a support. Their technology knowledge and technology tool skills were apparent in their presentations of the lesson materials as well as on each teacher's LMS. In fact, the research supports that having foundational technology skills, a high comfort level using technology, and an understanding of how content can be tied to technology leads to more meaningful technology integration (Harris \& Hofer, 2014, 2017; Koehler \& Mishra, 2009; Niess, 2011; Paratore et al., 2016). The longer and more intensively teachers use technology themselves leads to more student-centered practices with technology (Montrieux, \& Schellens, 2018; Montrieux et al., 2015).

Constructivist pedagogical beliefs were another support. Both Andrew and Diane called themselves "Constructivists," and all teachers' planning practices reflected constructivist commentaries (Bhattacharjee, 2015; Dewey, 1938; Terwel, 1999) as well as critical dimensions of technology use. High level technology skill sets coupled with constructivist pedagogical beliefs and practices have been shown to lead to more transformative and critical technology integration (Anderson \& Maninger, 2007; Chen, 2008; Ertmer, 2005; Ertmer et al., 2012; 
Koehler \& Mishra, 2009; Liu, 2011; Overbay et al., 2010; Ruggiero \& Mong, 2015; Sang et al., 2010; Tondeur, et al., 2013).

The standards cited in the lesson and unit plans lent support to engaging in critical dimensions. Diane, Kate, and Andrew cited standards as objectives in their lessons. Sara used the AP College Board's lesson plans which included both ties to standards as well as suggested technology integration practices as a means for presenting the content. The standards that Kate and Diane cited in their lesson plans supported both constructivist practices and technology integration. The standards Andrew cited did not include a technology integration component.

The teachers' practices reflected the focus that is being placed on teachers meeting standards. During a time of high-stakes accountability in our education system where curriculum is shaped by standards that include the critical integration of technology, researchers have recognized the challenges that higher education educators are facing about how to develop teacher digital literacy (Darling-Hammond, 2012; Hofer \& Grandgenett, 2012; Kozma, 2011; Niess, 2011). Niess (2011) proposed that the emphasis on technology in national standards dictated the need to develop teacher technology knowledge, and supports the consideration of redesigning teacher education coursework to reflect a TPACK approach. Other researchers believe that there should be a critical component included in that redesign (Avila \& Pandya, 2013; Burnett \& Merchant, 2011; Song, 2016; Watulak \& Kinzer, 2013).

\section{Limitations}

After completing the analysis of my data, identifying findings, and interpreting and discussing the findings in light of theory and previous research, I revisited the gaps that I initially identified through my literature review. While this study provided findings that can contribute to 
the body of research surrounding teachers' processes for recruiting C-TPACK into their teaching practices, there are noted limitations to consider that accompany these understandings.

First, the number of participants for Phase 1 of this study was limited. It is necessary to draw data from a large pool of participants in order to claim generalizability (Creswell, 2014). I used purposeful sampling to identify the subset of teachers who participated in Phase 2, which can result in selecting participants who are highly skilled and knowledgeable about the specific topic a researcher is interested in (Creswell \& Plano-Clark, 2011; Patton, 2002). However, that sampling came from a limited number of graduate students making the subset not wholly representative of a diversity of individuals.

Second, the observations were of only one lesson for each teacher. This produced limited data about their practices. Observing the teachers as they planned and instructed over a longer period of time could lead to a higher level of construct validity (Graham et al., 2012; Schmidt et al., 2009). As such, extending this study to include more lesson observations providing the researcher with "prolonged engagement and persistent observation in the field" (Corbin \& Strauss, 2015, p. 343) could have increased the credibility and trustworthiness of these findings. For example, all teachers stated in their interviews that they believed they used technology on a daily basis in their planning and instruction practices. Including observations of an entire unit plan of lessons could have provided additional information about what led them to believe that.

Third, while I have background in Language Arts and writing, I do not have that same level of knowledge in Physics and Spanish. That limited content knowledge could have impacted my ability to understand the barriers and supports that impact teachers of those content areas. In fact, I did have to educate myself about Newton's Laws to better understand Diane's lesson plan 
and instruction. I also had to enlist a translator for some of Sara's materials that accompanied her lesson plan.

\section{Implications}

"Critical literacies themselves can be intimidating to educators, but to couple them with digital literacies and ask teachers to figure out how to integrate the whole complete mess in an educational context that values measurable and testable skills (neither of which these are) often leaves us with present and future educators who are reluctant to engage with either the critical or the digital" (Avila \& Pandya, 2013, p. 6)

This quote aptly summarizes the findings in my study. While my study shed some light

on this issue, it was limited and my findings pointed to more work that needs to be done. In order to continue addressing the gaps in the research, both an examination of current practices in teacher education and PD programs, and more research directed at understanding how teachers recruit C-TPACK are needed. Below, I present implications my results have for future practice and research. In regard to future practices, there are sections dedicated to teacher education coursework and PD. After that, I provide my suggestions for future research which include consideration of the C-TPACK framework to guide studies and the inclusion of longitudinal studies to increase the credibility and construct validity of findings.

\section{Implications for Research}

Sociological perspectives on educational technology need to be drawn upon by more researchers and more writers in the field. These perspectives need to be taught to students of educational technology as a matter of course. Above all, everyone involved in the academic study of young people, education and technology needs to explore ways of putting these theories into action, and develop socially nuanced analyses that concentrate 
on the social as well as the technical issues underpinning the application of technology in educational settings. (Selwyn, 2012, p. 93)

Researchers have noted an absence in theoretical frameworks in studies that delve into the critical dimensions of technology integration practices of teachers (Avila \& Pandya, 2013; Burnett \& Merchant, 2011; Selwyn, 2012; Song, 2016; Watulak \& Kinzer, 2013). As I examined my own pedagogical, ontological, and epistemological beliefs, I recognized that a theoretical framework that supported my beliefs about the importance of critical theory as it relates to educational technology practices needed to be created. That led me to develop the C-TPACK framework. It was the C-TPACK framework that also led me to create a series of questions that get at a teacher's CDL knowledge which were combined with Schmidt et al.'s TPACK survey questions resulting in the C-TPACK survey used in this study. It is my hope that both the CTPACK framework and the C-TPACK survey will be used in future research to learn more about how teachers can learn to engage the critical dimensions of technology in their teaching.

\section{The C-TPACK Framework}

When conducting the literature review for my study, I discovered several gaps in the research that I believed needed attention. First, there was a noted absence of studies that examined the contexts surrounding the development and recruitment of TPACK. In fact, while many of the studies suggested context should be considered in future studies, those studies remained absent in the literature (Avila \& Pandya, 2013; Watulak \& Kinzer, 2013). This specifically caught my attention as my understanding of educational technology recruits a critical digital lens which was only limitedly represented in the studies reviewed. As I further delved into the research, I found that there was little mention of direct observational data in the studies where TPACK was being measured which indicated another gap in the literature. Also resulting 
from my review, I noted that the majority of studies surrounding TPACK measurement preservice and practicing teachers did not include following them into the classroom to study their actual recruitment of this knowledge into their practices. Specifically, there were a limited number of studies that focused on graduate students. That indicated to me that the studies surrounding TPACK were largely predictive and, as a result, the construct validity of those studies was not a focus. Selwyn (2012) explained that the principal advantage of the more socially nuanced theoretical approaches should be seen as the ability to develop a more socially grounded understanding of the 'messy' realities of educational technology as it happens (p. 93).

My review of literature led me to consider not only how to locate the missing critical component in studying teachers' practices, but also why it might be missing in the first place. I believed that to conduct this study, my theoretical framework needed to reflect the value that I placed on CDL when considering educational technology in teaching practices. As the frameworks that I looked at in my literature review did not fully represent my perspective, I developed a new framework that would. The result was the C-TPACK framework. The development of this framework provided me with a way to approach the gaps in the literature that reflected my own pedagogical, ontological, and epistemological beliefs surrounding educational technology. The C-TPACK framework guided my approach to understanding the gaps in the literature, the development of my research questions, my methodological choices, and my interpretations of and discussion about the findings. Using this framework caused me to continually prioritize the recognition and critical analysis of the ideologies and social factors that are embedded in digital literacies; consider necessary the inclusion of new technologies in the understanding and valuing of the development of student literacy; recognize the importance of connecting content, pedagogical, and technological knowledge to more meaningfully integrate 
technology; and value the participatory and collaborative practices of digital environments that contribute to student literacy. Importantly, this study led me to develop a new framework that can be used in future research when studying how teachers recruit different domains of knowledge into their teaching practices surrounding technology use.

\section{Moving away from a functionalist approach to a critical approach.}

Future research should move away from a functionalist approach and employ a critical approach. As explained in the literature review, much of the studies surrounding TPACK centered on a functionalist approach (Edmondson, 2002) and were largely quantitative. Study of teachers' recruitment of TPACK has been focused on prediction which "inhibits the capacity to question and challenge important issues such as ideology, race, class struggles, and power as they relate to literacy research, education and schooling" (Edmondson, 2002, p. 114). That issue can be resolved by both including a critical lens, such as that offered by the C-TPACK framework, in conjunction with collecting multiple sources of data. Koehler, Mishra, and Cain (2013) explained that utilizing a TPACK framework requires recognizing that these "do not exist in a vacuum, but rather, are instantiated in specific learning and teaching contexts" (p. 16). Functionalist research lacks the attention to context as does a TPACK framework without a critical component.

As my study showed, my use of the C-TPACK framework supported a mixed-methods approach where the inclusion of multiple data sources (both quantitative and qualitative) revealed relevant and important understandings about the processes teachers engage in when recruiting knowledge. This was a direct result of studying the participants in different contexts and analyzing the collected data from those multiple sources using a critical digital lens. This study provides an example of the way that joining different ontological paradigms can lead to 
valuable information about teachers' C-TPACK recruitment. As exemplified in my study, there is room for a dialectical relationship between the quantitative data and the qualitative data that a mixed-methods study can provide. Importantly, such an approach needs to be grounded on a theoretical framework that provides a foundation that supports the understanding that no single data source supersedes any other; instead, they have a symbiotic relationship.

As explained in Chapter 3, I revised Schmidt et al.'s (2009) survey to include questions specific to middle/secondary teachers. I also developed and included a new knowledge domain containing questions directed at a teacher's CDL. In the future, it would be helpful to conduct validation studies for this C-TPACK survey. This could include conducting initial observations to identify teachers whose actual instruction reflects C-TPACK as defined in the survey, and then following those observations with participation in the survey. In addition, the development and validation of an observation protocol could aid in that examination.

\section{Triangulating data.}

Concerns about validity that have been noted in previous TPACK studies (Archambault \& Barnett, 2010; Koh et al., 2014; Koh \& Divaharan, 2011) can be avoided using this approach in future research. Multiple sources allowed the use of constant comparative analysis resulting in triangulation which increased the construct validity in the findings. This is especially important considering the complexity of the relationships of the knowledge domains in C-TPACK. Again, I refer to Mishra and Koehler's (2009) statement about how those knowledge domains must work together to create a "dynamic equilibrium" (p. 67) resulting in more meaningful, transformative, and, with the addition of the " $\mathrm{C}$ " component, more critical. 


\section{Longitudinal Studies of Teacher's Recruitment of the "C" in C-TPACK}

As explained in the literature review, previous studies were largely predictive and as a result, the construct validity of those studies was limited. Most of the studies of TPACK did not include following pre-service and practicing teachers into the classroom to observe how their recruited their TPACK. Understanding the context where teachers engage in technology integration practices is considered a necessary component of TPACK (Koehler et al., 2013; Davies \& West, 2014). If the study of the measurement of a preservice teacher's TPACK is not connected to actual technology integration practices in his/her classroom, then the focus is on the predictive rather than the actual, the latter of which could provide construct validity (Charmaz, 2010; Corbin \& Strauss, 2015).

Another direction that longitudinal research could address is how pre-service teachers may have been informed by dominant ideologies regarding teaching, learning and using technology before entering teacher education programs. Where TPACK research has not directed attention to the critical component of beliefs about and practices with technology, employment of a C-TPACK framework in the study of pre-service teachers before and after completing teacher education programs could. Such studies could provide important direction about how to develop the CDL of future teachers. The same longitudinal study could also apply to graduate student coursework and PD programs ensuring that the critical dimensions of technology integration are considered in teachers' practices.

\section{Methodological approaches.}

Researchers should consider action and design-based research methodologies utilizing the C-TPACK framework when looking at the ways preservice (including both undergraduate and graduate) and practicing teachers recruit their CTPACK to their practices surrounding 
technology. Mishra and Koehler (2006) explained that such research "acknowledges the complexities of classroom teaching and enlightens both practitioners and researchers by leading to the development of theoretical ideas grounded in contexts of practice; design experiments narrow the gap between research and practice, between theory and application" (p. 118). The critical "C" in the C-TPACK framework provides a foundation for action based research as it can help uncover power structures and dominant discourses at work in digital environments. Once recognized and exposed, opportunities can be created for teachers and students to take action. Morrell (2014) explained this is necessary "not only for the critical navigation of hegemonic discourses; it is also essential to the redefining of the self and the transformation of oppressive social structures and relations of production" (p. 5).

Expanding on Morrell's (2014) promotion of transformation, future research could include transformative methodologies. Creswell (2013) explained that the purpose for using transformative methods centers on the concept that "knowledge is not neutral and it reflects the power and social relationships within society and thus the purpose of knowledge is to aid people to improve society" (p. 26). Utilizing the C-TPACK framework in transformative research could lead to pedagogical change that supports that understanding. In this study, the teachers permitted the observation of specific lessons they believed included technology integration and CDL practices rather than multiple lessons or units, which was a limitation of this study. Transformative research focuses on the collaboration of participants with the researcher where the research is conducted "with" rather than "on" them (Creswell, 2013, p. 26) potentially leading to transformation of all involved. Such research methods could lead to the development of a pool of participants for pre/post survey and the honing of the C-TPACK survey instrument and observation protocol instruments. 
Design-based research could also serve as a means for helping develop the C-TPACK of preservice and practicing teachers. Designing and studying coursework and PD that emphasize that development could provide a means for connecting critical theory to technology which was identified both as missing and as a barrier for engaging in the critical dimensions of teaching practices involving technology. Such research would provide valuable direction for teacher education and PD programs alike.

\section{Future Practices in Teacher Development}

My study revealed the importance that PD and teacher education coursework played in the teachers' decisions to engage in the critical dimensions of digital environments with their students. All four teachers stated that they received little to no coursework in applying critical theory to technology. In Diane's case, this resulted in her tightly controlling the access to any online environment that she had the students use in her classroom. She also avoided topics within her content that she felt could make her students uncomfortable. In Sara's case, she worried about controlling students' internet use during her lessons. Both she and Kate struggled in their practices with determining which resources were most authentic and reputable. Kate and Diane defined CDL largely as finding reputable resources, rather than as recognizing the power structures and dominant discourse operating within digital environments. Andrew had limited critical theory coursework and PD, but believed he applied critical theory in all of his teaching practices, including technology use, which did not prove to be the case regarding student technology use during his lesson.

Selwyn (2012) explained that without connecting theory with technology integration, there is risk that technological determinism could gain a stronghold. In a determinist view of technology "teachers, learners and everyone else involved in education are placed in a position 
of having to respond to technological change by making the 'best use' of the technologies that they are presented with" (p. 83). In that sense, teachers and students are led by technology rather than leading with technology. Selwyn (2012) went on to explain that

taking this perspective serves to obscure the many non-technological factors at play in the educational use of technology-thereby introducing a number of silences into any discussion of education and technology. Issues such as gender, race, social class, identity, power, inequality and so on are all sidelined in favour of the technological. (p. 83) This does not have to be the case, as educating preservice and practicing teachers in tying critical theory to technology can be addressed in teacher education and PD programs alike.

In fact, incorporating CDL practices into a teacher's planning and instruction with technology can provide the traditional context for TPACK that Mishra and Koehler (2006) explained is elemental to studying how teachers recruit TPACK to their practices as well as the critical context that I explained as necessary when digital environments are included in classroom practices. Importantly, my study found that the teachers' had limited exposure to modeling of C-TPACK during education coursework and limited professional development tying critical theory to technology. The teachers also had also limited education about critical literacy in their teacher education coursework. These absences and limitations were considered barriers for the recruitment of their own C-TPACK to their practices which highlighted ways that teacher education programs and PD for teachers can change in an effort to develop teachers' C-TPACK so that it can be recruited to their teaching practices.

\section{Teacher education coursework.}

University faculty hold the major responsibility of helping teacher candidates incorporate technology into their pedagogical thinking and instructional approach with future students. 
Importantly, many preservice teachers cite a lack of connection between technology and their content area education courses (Koehler et al., 2013; Sutton, 2011). Specifically, Sutton (2011) reported that teachers failed to make connections between the theoretical and methods curriculum courses and the stand-alone technology course required in teacher education programs. Sutton (2011) went on to state that in order for preservice teachers to benefit from educational technology exposure in their coursework, "all teacher education faculty must be skilled in using technology systems software appropriate to their subject area and model effective use as part of the preservice teachers' coursework" (p.45). As explained earlier, explicit belief exploration coupled with technology practices that enrich the curriculum and transform teaching and learning has been shown to equate to higher and more critical levels of integration (Ertmer et al., 2012; Koh et al., 2014; Overbay, et al., 2010; Prestridge, 2017; Ruggiero \& Mong, 2015).

This seems ideal, but may not necessarily be practical. It assumes that university faculty are themselves adept at connecting and modeling all knowledge domains within C-TPACK. In their study, Foulger et al. (2012) found that "Instructors who teach science, social studies, mathematics, and language arts methods courses may not be experts in teaching about technology integration; even if content instructors teach with technology, they may not be capable of teaching preservice candidates how to teach in PK-12 classrooms with technology" (p. 49). Add to that that most studies have not included looking at the CDL practices of instructors, and this barrier seems to become larger.

Teacher education courses and PD are pivotal in the development of teaching and learning beliefs that support technology integration (Anderson, Groulx, \& Maninger, 2011; Koehler and Mishra, 2009; Koh et al., 2014; Prestridge, 2017; Tondeur et al., 2013) and CDL 
practices (Avila \& Pandya, 2013; Burnett \& Merchant, 2011; Watulak \& Kinzer, 2013). Studies suggested that teacher candidates would benefit from opportunities during their observation and internship experiences to apply instructional technology practices specifically to their content areas and to witness other educators making the connection between pedagogy and technology use (Liu et al., 2015; Ruggiero \& Mong, 2015; Sutton, 2011; Tondeur et al., 2008). Avila and Pandya (2013) and Watulak and Kinzer (2013) believed that the modeling and technology integration coursework for all teachers must include a CDL component if technology use is to become transformative and meaningful. Burnett and Merchant (2011) stated that if the CDL component is not included in the students' technology use in the classroom, educators run the risk of allowing dominant discourses that are promoted in online environments to permeate the classrooms resulting in students who occupy the role of passive recipients. As the teachers did not engage in CDL practices during their instruction involving students technology use, that risk would apply to them. If it is absent in teachers' practices, there is a missed opportunity for their students to experience CDL being modeled and to develop their own CDL.

\section{Professional development.}

As PD is necessary for all teachers, PD programs offered by schools should be looked to as a means for developing the C-TPACK of teachers. In my study, the teachers had little to no exposure to CDL. Important discussions that enlighten administrators about the critical dimensions of digital environments must first take place. To accomplish this, school administration can be approached and engaged in conversation about how to offer PD that reflects this valuable research. Engaging in conversations with school administration about their school policies and restrictions surrounding technology and online environments provides an opportunity for discussion about moving past a sole focus on the "technical stuff" (p. 7) to 
consider the "ethos stuff" (p. 7) that Lankshear and Knobel (2007). Such discussion could push teacher development programs past the functionalist promotion of technology tools that promotes technological determinism.

Embedded teacher education to support technology integration practices within schools requires commitment and planning from school administration to help ensure longitudinal success. To accomplish this, when consulting with schools about the development and/or evolution of, their technology plans, PD that supports engaging in the critical dimensions of teachers' technology integration practices should be included.

Importantly, PD planning should also consider of the needs and requests of the teachers. As shown in my study, all teachers said time was a barrier for their engagement in the critical dimensions of technology in instruction. It also showed that they valued tying critical theory to technology practices, but had little to no exposure to that. Incorporation of evaluations into schools' technology plans should be considered as it can help ensure that the CDL needs of the teachers could be met during time that is already dedicated to PD.

While the teachers in my study did not complete a structured evaluation of their PD for this study, Guskey's (2014) suggestions can be applied to their statements about their PD experiences and opinions as they relate to CDL. The teachers' stated understandings and examples of their CDL practices with students did not all reflect critical theory applications (Avila \& Pandya, 2013). This is an important finding as this absence can lead to teachers and their students unknowingly accepting power structures and dominant discourses at play in the online environments they are engaging in. Even more, as was the case in this study, that uncertainty and/or misunderstanding about what critical theory looks like in digital environments 
can lead to decisions about technology integration that perhaps unwittingly promote dominant ideologies.

\section{Final Thoughts}

Edmondson (2002) stated that "the work in and around schools is unavoidably political, and for this reason, values cannot be separated from the facts or choices made" (p. 114). My study contributes to a very limited amount of research that considers the CDL of teachers as it relates to their teaching practices. Using digital platforms in combination with a CDL framework can potentially give educators and students learning opportunities about how to become more socially aware and empowered by their personal beliefs and values. Specifically, online spaces can provide opportunities for students to see how they are positioned in their networked relationships and in society as a whole. When educators recruit a critical digital lens into their teaching practices, they can challenge the hegemonic power of the few and "...equip students with the mindset needed to help shape their culture." (Garcia et al., 2013, p. 113). 


\section{REFERENCES}

Anderson, S. E., Groulx, J. G., \& Maninger, R. M. (2011). Relationships among preservice teachers' technology-related abilities, beliefs, and intentions to use technology in their future classrooms. Journal of Educational Computing Research, 45(3), 321-338.

Anderson, S. E., \& Maninger, R. M. (2007). Preservice teachers' abilities, beliefs, and intentions regarding technology integration. Journal of Educational Computing Research, 37(2), 151-172.

Archambault, L. M., \& Barnett, J. H. (2010). Revisiting technological pedagogical content knowledge: Exploring the TPACK framework. Computers \& Education, 55(4), 16561662.

Atkins, D., Bennett, J., Brown, J. S., Chopra, A., Dede, C., Fishman, B., \& Williams, B. (2010). Transforming American education: Learning powered by technology. National educational technology plan 2010. Washington, D.C.: U.S. Department of Education, Office of Educational Technology.

Avila, J., \& Pandya, J.Z. (2013). Traveling, textual authority, and transformation: An introduction to critical digital literacies. In J. Avila \& J.Z. Pandya (Eds.), Critical digital literacies as social praxis (pp. 127-153). New York, NY: Peter Lang.

Bada, S. O., \& Olusegun, S. (2015). Constructivism learning theory: A paradigm for teaching and learning. Journal of Research \& Method in Education, 5(6), 66-70.

Ball, D. L., \& Forzani, F. M. (2011). Building a common core for learning to teach: And connecting professional learning to practice. American Educator, 35(2), 17-39.

Bandura, A. (1977). Self-efficacy: Toward a unifying theory of behavioral change. Psychological Review, 84, 191-215. 
Banister, S., \& Reinhart, R.V. (2012). Assessing NETS• T performance in teacher candidates: Exploring the way find teacher assessment. Journal of Digital Learning in Teacher Education, 29(2), 59-65.

Battersby, S. L., \& Verdi, B. (2015). The culture of professional learning communities and connections to improve teacher efficacy and support student learning. Arts Education Policy Review, 116(1), 22-29.

Bennett, W. L. (2008). Changing citizenship in the digital age. In W. L. Bennett (Ed.), Civic life online: Learning how digital media can engage youth (pp. 1-24). Cambridge, MA: The MIT Press.

Benton-Borghi, B. H. (2013). A universally designed for learning (UDL) infused technological pedagogical content knowledge (TPACK) practitioners' model essential for teacher preparation in the 21st Century. Journal of Educational Computing Research, 48(2), 245265.

Benton-Borghi, B. H. (2016). Universal design for learning (UDL) infused technological pedagogical content knowledge (TPACK) model prepares efficacious 21st-Century teachers. In M.C Herring, M.J. Koehler, \& p. Mishra (Eds.) Handbook of technological pedagogical content knowledge (TPACK) for educators (pp. 143-164). New York, NY: Routledge.

Bhatt, I., de Roock, R., \& Adams, J. (2015). Diving deep into digital literacy: Emerging methods for research. Language and Education, 29(6), 477-492.

Bhattacharjee, J. (2015). Constructivist approach to learning-an effective approach of teaching learning. International Research Journal of Interdisciplinary \& Multidisciplinary Studies, $1(6), 65-74$. 
Blikstad-Balas, M. (2015). Digital literacy in upper secondary school-what do students use their laptops for during teacher instruction?. Nordic Journal of Digital Literacy, 10(Summer), 122-137.

Bloor, M. \& Wood, F. (2006). Keywords in qualitative methods. Thousand Oaks, CA: Sage. Bourdieu, p. (1986). The forms of capital. In J. E. Richardson (Ed.), Handbook of theory of research for the sociology of education (pp. 241-258). Westport, CT: Greenwood Publishing Group.

boyd, d. (2007). Why youth (heart) social network sites: The role of networked publics in teenage social life. In D. Buckingham (Ed.), MacArthur foundation series on digital learning-Youth, identity, and digital media volume (pp. 119-142). Cambridge, MA: The MIT Press.

Bruneel, S., De Wit, K., Verhoeven, J., \& Elen, J. (2013). Facebook-when education meets privacy. Interdisciplinary Journal of E-Learning and Learning Objects, 9, 125-148.

Buckingham, D. (2008). Defining digital literacy: What do young people need to know about digital media? In C. Lankshear \& M. Knobel (Eds.), Digital literacies: Concepts, policies and practices (pp. 73-89). New York, NY: Peter Lang.

Buckingham, D. (2003). Media education. Cambridge, MA: MIT Press.

Burnett, C., \& Merchant, G. (2011). Is there a space for critical literacy in the context of social media? English Teaching, 10(1), 41-57.

Bybee, R. W., Taylor, J. A., Gardner, A., Van Scotter, P., Powell, J. C., Westbrook, A., \& Landes, N. (2006). The BSCS 5E instructional model: Origins and effectiveness. BSCS, $5,88-98$. 
Carpenter, J. P. , \& Krutka, D. G. (2014). How and why educators use Twitter: A survey of the field. Journal of Research on Technology in Education, 46(4), 414-434.

Chai, C. S., Koh, J. H. L., \& Tsai, C. C. (2010). Facilitating preservice teachers' development of technological, pedagogical, and content knowledge (TPACK). Journal of Educational Technology \& Society, 13(4), 63-73.

Charmaz, K. (2014). Constructing grounded theory. London: Sage Publications, Inc.

Charmaz K. (1995). Grounded theory. In J. Smith, R. Harré, \& L. Langenhove (Eds.), Rethinking methods in psychology (pp. 27-65). London: Sage Publications, Inc.

Charmaz, K. (2010). Grounded theory: Objectivist and constructivist methods. In W. Lutrell (Ed.), Qualitative educational research (pp. 183-207). New York, NY: Routledge.

Charmaz K. (2001). Qualitative interviewing and grounded theory analysis. In Gubrium J., Holstein J. (Eds.), Handbook of interview research: Context and method (pp. 675-694). Thousand Oaks, CA: Sage.

Charmaz K., \& Mitchell R. (1996). The myth of silent authorship: Self, substance, and style in ethnographic writing. Symbolic Interaction, 19(4), 285-302.

Chen, C. H. (2008). Why do teachers not practice what they believe regarding technology integration?. The journal of educational research, 102(1), 65-75.

Chen, R. J. (2010). Investigating models for preservice teachers' use of technology to support student-centered learning. Computers \& Education, 55(1), 32-42.

Chen, W. (2013). The implications of social capital for the digital divides in America. The Information Society, 29(1), 13-25.

Choudbury, M., \& Share, J. (2012). Critical media literacy: A pedagogy for new literacies and urban youth. Voices from the Middle, 19(4), 39-44. 
Cohen, L., Manion, L., \& Morrison, K. (2007). Research methods in education. New York, NY: Routledge. https://dspace.utamu.ac.ug/bitstream/123456789/182/1/Research-Methods-inEducation-sixth-edition.pdf

Conley, D. T. (2011). Building on the common core. Educational Leadership,68(6), 16-20.

Cope, B., \& Kalantzis, M. (2009). "Multiliteracies": New literacies, new learning. Pedagogies: An International Journal, 4(3), 164-195. Retrieved from http://newlearningonline.com/files/2009/03/m-litspaper13apr08.pdf

Cope, B., \& Kalantzis, M. (2015). The things you do to know: An introduction to the pedagogy of multiliteracies. In A Pedagogy of Multiliteracies (pp. 1-36). London: Palgrave Macmillan UK.

Corbin, J., \& Strauss, A. (2015). Basics of qualitative research: Techniques and procedures for developing grounded theory (4th ed.). Thousand Oaks, CA: Sage.

Council for the Accreditation of Educator Preparation. (2017). The CAEP standards. Retrieved from: http://caepnet.org/standards/introduction

Crafton, L. K., Brennan, M., \& Silvers, P. (2007). Critical inquiry and multiliteracies in a firstgrade classroom. Language Arts, p510-518.

Creswell, J., \& Plano Clark, V.L. (2011). Designing and conducting mixed method research. Thousand Oaks, CA: Sage Publications.

Creswell, J. (2014). Research design: Qualitative, quantitative, and mixed methods approaches. Thousand Oaks, CA: Sage Publications.

Cuban, L. (2009). Oversold and underused. Cambridge, MA: Harvard University Press. 
Dabbagh, N., \& Kitsantas, A. (2012). Personal Learning Environments, social media, and selfregulated learning: A natural formula for connecting formal and informal learning. The Internet and Higher Education, 15(1), 3-8.

Darling-Hammond, L. (2012). Creating a strong foundation for the teaching career. Kappan, November, 8-13.

Davies, R. S., \& West, R. E. (2014). Technology integration in schools. In Handbook of research on educational communications and technology (pp. 841-853). Springer New York.

Deng, F., Chai, C. S., Tsai, C. C., \& Lee, M. H. (2014). The relationships among Chinese practicing teachers' epistemic beliefs, pedagogical beliefs and their beliefs about the use of ICT. Journal of Educational Technology \& Society, 17(2), 245-256.

Dewey, J. (1938). Experience and education. New York, NY: Collier.

Domonoske, C. (2016, December 23). Students have dismaying inability to tell fake news from real, study finds. Retrieved from: http://www.npr.org/sections/thetwoway/2016/11/23/503129818/study-finds-students-have-dismaying-inability-to-tell-fakenews-from-real

Dowdall, C. (2009). Masters and critics: Children as producers of online digital texts. In V. arrington \& M. Robinson (Eds.), Digital literacies: Social learning and classroom practices (pp. 43-62). London: Sage.

Draper, R. J., \& Wimmer, J. J. (2015). Acknowledging, noticing, and reimagining disciplinary instruction: The promise of new literacies for guiding research and practice in teacher education. Action In Teacher Education, 37(3), 251. 
Duffin, L. C., French, B. F., \& Patrick, H. (2012). The teachers' sense of efficacy scale: Confirming the factor structure with beginning pre-service teachers. Teaching and Teacher Education, 28, 827-834. http://dx.doi.org.proxy.lib.utk.edu:90/10.1016/j.tate.2012.03.004

DuFour, R., \& Mattos, M. (2013). How do principals really improve schools? Educational Leadership, 70(7), 34-39.

Edmundson, J. (2002). Asking different questions: Critical analysis and reading research. Reading Research Quarterly, 37(1), 113-119.

Ellison, N. B., Steinfield, C., \& Lampe, C. (2007). The benefits of Facebook "friends": Social capital and college students' use of online social network sites. Journal of ComputerMediated Communication, 12(4), 1143-1168.

Erstad, O. (2012). The learning lives of digital youth—-beyond the formal and informal. Oxford Review of Education, 38(1), 25-43.

Ertmer, P. (2005). Teacher pedagogical beliefs: The final frontier in our quest for technology integration? Educational Technology Research and Development, 53(4), 25-39.

Ertmer, P. A. Ottenbreit-Leftwich. (2013). Removing obstacles to the pedagogical changes required by Jonassen's vision of authentic technology-enabled learning. Computers \& Education, vol. 64, pp. 175-182.

Ertmer, P. A., Ottenbreit-Leftwich, A. T., \& Tondeur, J. (2014). Teachers' beliefs and uses of technology to support 21 st-century teaching and learning. In H. Fives \& M.G. Gill (Eds.), International handbook of research on teacher beliefs (pp. 403-424). 
Ertmer, P. A., Ottenbreit-Leftwich, A. T., Sadik, O., Sendurur, E., \& Sendurur, P. (2012). Teacher beliefs and technology integration practices: A critical relationship. Computers \& Education, 59(2), 423-435.

Flynn, K. (2016, February 25). Facebook users show range of reactions to new love, haha, sad, angry, wow emoticons. International Business Times. Retrieved from http://www.ibtimes.com/

Foulger, T. S., Buss, R. R., Wetzel, K., \& Lindsey, L. (2012). Preservice teacher education benchmarking a standalone ed tech course in preparation for change. Journal of Digital Learning in Teacher Education, 29(2), 48-58.

Freire, P. (1970). Pedagogy of the Oppressed. New York, NY: Bloomsbury Publishing.

Freire, P. (1973). Education as the practice of liberty. New York, NY: McGraw Hill.

Freire, P. , \& Macedo, D. (1987). Literacy: Reading the word and the world. New York: Routledge.

Friesen, N., \& Lowe, S. (2012). The questionable promise of social media for education: Connective learning and the commercial imperative. Journal of Computer Assisted Learning, 28(3), 183-194.

Fuchs, C. (2014). Social media: A critical introduction. London, England: Sage Publications Ltd. Gainer, J. S. (2010). Critical media literacy in middle school: Exploring the politics of representation. Journal of Adolescent \& Adult Literacy, 53(5), 364-373.

Garcia, A. (2013). Utilizing mobile media and games to develop critical inner-city agents of social change. In J. Avila \& J.Z. Pandya (Eds.), Critical digital literacies as social praxis (pp. 107-125). New York, NY: Peter Lang. 
Garcia, A., Seglem, R., \& Share, J. (2013). Transforming teaching and learning through critical media literacy pedagogy. Learning Landscapes, 6(2), 109-124.

García, A., Mirra, N., Morrell, E., Martínez, A., \& Scorza, D. A. (2015). The council of youth research: Critical literacy and civic agency in the digital age. Reading \& Writing Quarterly, 31(2), 151-167.

Gee, J. P. (2004). Situated language and learning: A critique of traditional schooling. New York, NY: Routledge.

Gee, J. P. (2005). The new literacy studies: From "socially situated" to the work. In D. Barton, M. Hamilton, \& R. Ivanič, (Eds.), Situated literacies: Reading and writing in context (pp. 177-194). London: Psychology Press.

Gee, J. P. (2010). A situated-sociocultural approach to literacy and technology. In E. A. Baker (Ed.), The new literacies: Multiple perspectives on research and practice (pp. 165-193). New York, NY: The Guilford Press. Retrieved from: http://jamespaulgee.com/geeimg/pdfs/Literacy\%20and\%20Technology.pdf

Gee, J. P. (2012a). Discourse and 'the new literacy studies'. The Routledge handbook of discourse analysis (pp. 371-382). Abingdon, UK: Routledge.

Gee, J.P. (2012b). Social linguistics and literacies: Ideology in discourses. London, England: Routledge.

Gee, J. P. (2014). An introduction to discourse analysis: Theory and method. New York:Routledge.

Gil de Zúñiga, H., Jung, N., \& Valenzuela, S. (2012). Social media use for news and individuals' social capital, civic engagement and political participation. Journal of ComputerMediated Communication, 17(3), 319-336. 
Gilboy, M. B., Heinerichs, S., \& Pazzaglia, G. (2015). Enhancing student engagement using the flipped classroom. Journal of Nutrition Education and Behavior, 47(1), 109-114.

Giroux, H. A. (1988). Schooling and the struggle for public life: Critical pedagogy in the modern age. MN: University of Minnesota Press.

Giroux, H. A. (2009). Critical theory and educational practice. In A. Darder, M. Baltodano, \& R. Torres (Eds.), The critical pedagogy reader ( $2^{\text {nd }}$ ed., pp. 27-51). New York and London: Routledge.

Glaser, B. G. (2002, September). Constructivist grounded theory?. In Forum qualitative sozialforschung/forum: Qualitative social research (Vol. 3, No. 3).

Glesne, C. (2016). Becoming qualitative researchers: An introduction. Boston, MS: Pearson Education, Inc.

Good, T.L. \& Brophy, J.E. (1994). Looking in classrooms. New York, NY: HarperCollins.

Gorder, L. M. (2008). A study of teacher perceptions of instructional technology integration in the classroom. The Journal of Research in Business Education, 50(2), 63-76.

Graham, C. R., Borup, J., \& Smith, N. B. (2012). Using TPACK as a framework to understand teacher candidates' technology integration decisions. Journal of Computer Assisted Learning, 28(6), 530-546.

Greene, J. (2010). Knowledge accumulation: Three views on the nature and role of knowledge in social science. In W. Luttrell (Ed.), Qualitative educational research: Readings in reflexive methdology and transformative practice (pp. 63-77). New York, NY:

Routledge. 
Greenhow, C., \& Robelia, B. (2009). Old communication, new literacies: Social network sites as social learning resources. Journal of Computer-mediated Communication, 14(4), 11301161.

Greenhow, C., Robelia, B., \& Hughes, J. E. (2009). Learning, teaching and scholarship in a digital age: Web 2.0 and classroom research: What path should we take now? Educational Researcher, 38(4), 246-259.

Handsfield, L. (2016). Literacy theory as practice: Connecting literacy theory and practice in K12 classrooms. New York: Teachers College Press.

Handsfield, L. J., Dean, T. R., \& Cielocha, K. M. (2009). Becoming critical consumers and producers of text: Teaching literacy with Web 1.0 and Web 2.0. The Reading Teacher, 63(1), 40-50.

Harris, J., \& Hofer, M. J. (2014). The construct is in the eye of the beholder: School districts' appropriations and reconceptualizations of TPACK. In L. Liu \& D.C. Gibson (Eds.), Research highlights in technology and teacher education (pp. 11-18). Waynesville, NC: Association for the Advancement of Computing in Education. Retrieved from http://publish.wm.edu/cgi/viewcontent.cgi?article=1004\&context=bookchapters

Hay, I. (Ed.). (2005). Qualitative research methods in human geography. New York, NY: Oxford University Press.

Henderson, M. (2015). The (Mis)use of community of practice: Delusion, confusion, and instrumentalism in educational technology research. In S. Bulfin, N. Johnson \& C. Bigum (Eds.), Critical perspectives on technology and education (pp. 128-140). 
Hobbs, R., \& Coiro, J. (2016). Everyone learns from everyone. Journal of Adolescent \& Adult Literacy, 59(6), 623-629.

Hofer, M., \& Grandgenett, N. (2012). TPACK development in teacher education: A longitudinal study of preservice teachers in a secondary MA Ed. program. Journal of Research on Technology in Education, 45(1), 83-106.

Hofer, M., Grandgenett, N., Harris, J. B., \& Swan, K. (2011). Testing a TPACK-Based technology integration observation instrument. Paper presented at the Teacher Education Faculty Proceedings \& Presentations.

Holzberger, D., Philipp, A., \& Kunter, M. (2013). How teachers' self-efficacy is related to instructional quality: A longitudinal analysis. Journal of Educational Psychology, 105(3), 774-786. http://dx.doi.org.proxy.lib.utk.edu:90/10.1037/a0032198

Hughes, A. (2009). Higher education in a Web 2.0 world. Bristol, England: JISC. Retrieved from http://www.jisc.ac.uk/media/documents/publications/heweb20rptv1.pdf

Huijser, H. (2006). Refocusing multiliteracies for the net generation. International Journal of Pedagogies and Learning, 2(1), 22-34.

Inan, F. A., \& Lowther, D. L. (2010). Factors affecting technology integration in K-12 classrooms: A path model. Educational Technology Research and Development, 58(2), $137-154$.

Janks, H. (2000). Domination, access, diversity, and design: A synthesis for critical literacy education. Educational Review 52(2), 175-186.

Johnson, N. (2015). The work of theory in ed-tech research. In S. Bulfin, N.F. Johnson, \& C. Bigum (Eds.), Critical perspectives on technology and education (pp. 35-50). New York, NY: Palgrave Macmillan. 
Johnson, R. B. (2011). Do we need paradigms? A mixed methods perspective. Mid-Western Educational Researcher, 24(2), 31-40.

John-Steiner, V., \& Mahn, H. (1996). Sociocultural approaches to learning and development: A Vygotskian framework. Educational psychologist, 31(3-4), 191-206.

Jonassen, D.H., \& Reeves, T. (1996). Learning with technology: Using computers as cognitive tools. In D. H. Jonassen (Ed.), Handbook of research for educational communications and technology (pp. 210-248).

Jones, R. H., \& Hafner, C. A. (2012). Understanding digital literacies: A practical introduction (pp. 59-69). New York: Routledge.

Kellner, D., \& Share, J. (2007). Critical media literacy is not an option. Learning Inquiry, 1(1), $59-69$.

Kihoza, P., Zlotnikova, I., Bada, J., \& Kalegele, K. (2016). Classroom ICT integration in Tanzania: Opportunities and challenges from the perspectives of TPACK and SAMR models. International Journal of Education and Development Using Information and Communication Technology, 12(1), 107-128.

Kim, C., Kim, M. K., Lee, C., Spector, J. M., \& DeMeester, K. (2013). Teacher beliefs and technology integration. Teaching and Teacher Education, 29, 76-85.

Kirschner, p. A. (2015). Facebook as learning platform: Argumentation superhighway or deadend street? Computers in Human Behavior, 53, 621-625.

Kivunja, C., \& Kuyini, A. B. (2017). Understanding and applying research paradigms in educational contexts. International Journal of Higher Education, 6(5), 26-41.

Knobel, M., \& Lankshear, C. (2006). Discussing new literacies. Language Arts, 84(1), 78-86. 
Knobel, M., \& Lankshear, C. (2014). Studying new literacies. Journal of Adolescent \& Adult Literacy, 58(2), 97-101.

Koehler, M. J., \& Mishra, p. (2009). What is technological pedagogical content knowledge? Contemporary Issues in Technology and Teacher Education, 9(1), 60-70.

Koehler, M. J., Mishra, p. , \& Cain, W. (2013). What Is Technological Pedagogical Content Knowledge (TPACK)? Journal Of Education, 193(3), 13-19.

Koh, J. H., Chai, C. S., \& Tsai, C. C. (2014). Demographic factors, TPACK constructs, and teachers' perceptions of constructivist-oriented TPACK. Educational Technology \& Society, 17(1), 185-196.

Koh, J. H., \& Divaharan, H. (2011). Developing pre-service teachers' technology integration expertise through the TPACK-developing instructional model. Journal of Educational Computing Research, 44(1), 35-58.

Kopcha, T. J. (2012). Teachers' perceptions of the barriers to technology integration and practices with technology under situated professional development. Computers \& Education, 59(4), 1109-1121.

Kozma, R. B. (1994). Will media influence learning? Reframing the debate. Educational technology research and development, 42(2), 7-19.

Kozma, R. B. (2011). ICT, education transformation, and economic development: An analysis of the US national educational technology plan. E-Learning and Digital Media, 8(2), 106120.

Lankshear, C., \& Knobel, M. (2007). Researching new literacies: Web 2.0 practices and insider perspectives. E-Learning and Digital Media, 4(3), 224-240. 
Lankshear, C., \& Knobel, M. (2008). Digital literacies: Concepts, policies and practices (Vol. 30). New York, NY: Peter Lang.

Lave, J., \& Wenger, E. (1991). Situated learning: Legitimate peripheral participation. Cambridge, United Kingdom: Cambridge University Press.

Lawless, K. A., \& Pellegrino, J. W. (2007). Professional development in integrating technology into teaching and learning: Knowns, unknowns, and ways to pursue better questions and answers. Review of Educational Research, 77(4), 575-614.

Leinhart, A. (2015). Teens, social media \& technology: Overview 2015. Retrieved from http://www.pewinternet.org/2015/04/09/teens-social-media-technology-2015/

Leu, D. J., Kiili, C., \& Forzani, E. (2016). Individual differences in the new literacies of online research and comprehension. In P. Afflerbach (Ed.), Handbook of individual differences in reading: Reader, text, and context (pp. 259-272). New York, NY: Routledge.

Leu, D. J., Kinzer, C. K., Coiro, J. L., \& Cammack, D. W. (2004). Toward a theory of new literacies emerging from the Internet and other information and communication technologies. Theoretical models and processes of reading, 5(1), 1570-1613.

Lim, J., \& Richardson, J. C. (2016). Exploring the effects of students' social networking experience on social presence and perceptions of using SNSs for educational purposes. The Internet and Higher Education, 29, 31-39.

Liu, S. H. (2011). Factors related to pedagogical beliefs of teachers and technology integration. Computers \& Education, 56(4), 1012-1022.

Liu, S. H., Tsai, H. C., \& Huang, Y. T. (2015). Collaborative professional development of mentor teachers and preservice teachers in relation to technology integration. Journal of Educational Technology \& Society, 18(3), 161-172. 
Louis, K. S., \& Wahlstrom, K. (2011). Principals as cultural leaders. Phi Delta Kappan, 92(5), $52-56$.

Luke, A., \& Freebody, P. (1997). Shaping the social practices of reading. In S. Muspratt, A. Luke, \& P. Freebody (Eds.), Constructing critical literacies: Teaching and learning textual practice (pp. 185-225). Cresskill, NJ: Hampton Press.

Luke, A., \& Freebody, P. (1999). Further notes on the four resources model. Reading Online. Retrieved from http://www.readingonline.org/research/lukefreebody.html

MacKinnon, G. R. (2017). Highlighting the Importance of Context in the TPACK model: Three cases of non-traditional settings. Issues and Trends in Educational Technology, 5(1), 416.

Manca, S., \& Ranieri, M. (2016). "Yes for sharing, no for teaching!”: Social media in academic practices. The Internet and Higher Education, 29, 63-74.

Mao, J. (2014). Social media for learning: A mixed methods study on high school students' technology affordances and perspectives. Computers in Human Behavior, 33, 213-223.

Martin, A. (2005). DigEuLit-a European framework for digital literacy: a progress report. Journal of eLiteracy, 2(2), 130-136.

McGloughlin, C., \& Lee, M. J. W. (2010). Personalised and self-regulated learning in the Web 2.0 era: International exemplars of innovative pedagogy using social software. Australasian Journal of Educational Technology, 26(1), 28-43.

Meneses, J., \& Mominó, J. M. (2010). Putting digital literacy in practice: How schools contribute to digital inclusion in the network society. The Information Society, 26(3), p197-208.

Meyers, E. M., Erickson, I., \& Small, R. V. (2013). Digital literacy and informal learning environments: An introduction. Learning, media and technology, 38(4), 355-367. 
Miles, M.B., Huberman, M., \& Saldana, J. (2014). Qualitative data analysis: A methods sourcebook. Thousand Oaks, CA: Sage Publications, Inc.

Mills, J., Bonner, A., \& Francis, K. (2006). The development of constructivist grounded theory. International Journal of Qualitative Methods, 5(1), 25-35.

Mills, K. A. (2009). Multiliteracies: Interrogating competing discourses. Language and education, 23(2), 103-116.

Mishra, p. , \& Koehler, M. J. (2006). Technological pedagogical content knowledge: A framework for teacher knowledge. Teachers College Record, 108(6), 1017-1054.

Montrieux, H., \& Schellens, T. (2018). The didactical use of tablets: a balancing act between teacher-centred and learner-centred education. Paper presented at the 12th annual International Technology, Education and Development Conference.

Montrieux, H., Vanderlinde, R., Schellens, T., \& De Marez, L. (2015). Teaching and learning with mobile technology: A qualitative explorative study about the introduction of tablet devices in secondary education. PloS one, 10(12), e 0144008 .

Moran, M., Seaman, J., \& Tinti-Kane, H. (2011). Teaching, learning, and sharing: How today's higher education faculty use social media. Boston, MA: Pearson Learning Solutions. Retrieved from http://www.pearsonlearningsolutions.com/higher-education/social-mediasurvey.php

Morgan, D. L. (2007). Paradigms lost and pragmatism regained: Methodological implications of combining qualitative and quantitative methods. Journal of Mixed Methods Research, 1(1), 48-76.

Morrell, E. (2015). Critical literacy and urban youth: Pedagogies of access, dissent, and liberation. New York, NY: Routledge. 
Myers, J., \& Eberfors, F. (2010). Globalizing English through intercultural critical literacy. English Education, 42, 148-170.

National Education Association. (2008). Technology in schools: The ongoing challenge of access, adequacy, and equity. Policy Brief \#19. Washington, DC: NEA Policy and Practice Department. Retrieved from www.nea.org/assets/docs/PB19_Technology08.pdf.

National Governors Association Center for Best Practices \& Council of Chief State School Officers. (2010). Common Core State Standards. Washington, DC: Authors. Retrieved from http://www.corestandards.org/

NGSS Lead States. 2013. Next Generation Science Standards: For States, By States. Washington, DC: The National Academies Press.

Niess, M. L. (2011). Investigating TPACK: Knowledge growth in teaching with technology. Journal of Educational Computing Research, 44(3), 299-317.

Oakley, G., \& Pegrum, M. (2014). 'Where do you switch it on?' A Case study of the enhancement and transformation of university lecturers' teaching practices with digital technologies. Education Research \& Perspectives, 41(1), 42-72.

Office of Planning, Research and Policy Analysis, Illinois State University. (2016). University factbook, fall 2016. Retrieved from: https://prpa.illinoisstate.edu/Book2016-Final.pdf

Olthouse, J. M. (2013). Multiliteracies theory and gifted education: Creating "smart spaces" in the language arts classroom. Gifted Child Today, 36(4), 246-253.

Overbay, A., Patterson, A., Vasu, E., \& Grable, L. (2010). Constructivism and technology use: Findings from the impacting leadership project. Educational Media International, 47(2), $103-120$. 
Pamuk, S. (2012). Understanding preservice teachers' technology use through TPACK framework. Journal of Computer Assisted Learning, 28(5), 425-439.Pangrazio, L. (2016). Reconceptualising critical digital literacy. Discourse: Studies in the Cultural Politics of Education, 37(2), 163-174.

Paratore, J. R., O’Brien, L. M., Jiménez, L., Salinas, A., \& Ly, C. (2016). Engaging preservice teachers in integrated study and use of educational media and technology in teaching reading. Teaching and Teacher Education, 59, 247-260.

Patton, M. Q. (1999). Enhancing the quality and credibility of qualitative analysis. Health services research, 34(5, Part II), 1189-1208.

Patton. M. Q. (2002). Qualitative research and evaluation methods. Thousand Oaks, CA: Sage Publications.

Porras-Hernández, L. H., \& Salinas-Amescua, B. (2013). Strengthening TPACK: A broader notion of context and the use of teacher's narratives to reveal knowledge construction. Journal of Educational Computing Research, 48(2), 223-244.

Potter, J. (2012). Digital media and learner identity. New York, NY: Palgrave Macmillan.

Potter, J., \& Banaji, S. (2011). Social media and self-curatorship. Comunicar, 38, 83-91.

Prestridge, S. (2017). Examining the shaping of teachers' pedagogical orientation for the use of technology. Technology, Pedagogy and Education, 26(4), 367-381.

Puentedura, R. (2006). Transformation, technology, and education. Retrieved from http://hippasus.com/resources/tte/ 
Reidel, M., \& Draper, C. A. (2011). Reading for democracy: Preparing middle-grades social studies teachers to teach critical literacy. Social Studies, 102(3), 124-131.

Riedl, C., Köbler, F., Goswami, S., \& Kremar, H. (2013). Tweeting to feel connected: A model for social connectedness in online social networks. International Journal of HumanComputer Interaction, 29(10), 670-687.

Roblyer, M. D., McDaniel, M., Webb, M., Herman, J., \& Witty, J. V. (2010). Findings on Facebook in higher education: A comparison of college faculty and student uses and perceptions of social networking sites. The Internet and Higher Education, 13(3), 134140.

Roblyer, M. D., \& Wiencke, W. (2004). Exploring the interaction equation: Validating a rubric to assess and encourage interaction in distance courses. The Journal of Asynchronous Learning Networks, 8(4), 24-37.

Roehl, A., Reddy, S. L., \& Shannon, G. J. (2013). The flipped classroom: An opportunity to engage millennial students through active learning strategies. Journal of Family \& Consumer Sciences, 105(2), 44-49.

Rosenberg, J. M., \& Koehler, M. J. (2015). Context and technological pedagogical content knowledge (TPACK): A systematic review. Journal of Research on Technology in Education, 47(3), 186-210.

Ruggiero, D., \& Mong, C. J. (2015). The teacher technology integration experience: Practice and reflection in the classroom. Journal of Information Technology Education, 14, 162-178.

Saldana, J. (2016). The coding manual for qualitative researchers. London, England: SAGE Publications Ltd. 
Savin-Baden, M., \& Howell-Major, C. (2013) Qualitative research: The essential guide to theory and practice. New York, NY: Routledge.

Sawers, K. M., Wicks, D., Mvududu, N., Seeley, L., \& Copeland, R. (2016). What Drives Student Engagement: Is it Learning Space, Instructor Behavior or Teaching Philosophy?. Journal of Learning Spaces, 5(2), 26-38.

Schmidt, D. A., Baran, E., Thompson, A. D., Mishra, p., Koehler, M. J., \& Shin, T. S. (2009). Technological pedagogical content knowledge (TPACK): The development and validation of an assessment instrument for preservice teachers. Journal of Research on Technology in Education, 42(2), 123-149.

Schrader, P. G., \& Lawless, K. A. (2004). The knowledge, attitudes, and behaviors (KAB) approach: How to evaluate performance and learning in complex environments. Performance Improvement, 43(9), 8-15.

Schram, T. (2006). Conceptualizing and proposing qualitative research (2nd ed.). Upper Saddle River, NJ: Pearson Education.

Selfe, C. (1990). Technology in the English classroom: Computers through the lens of feminist pedagogy. In C. Handa (Ed.), Computers and community: Teaching composition in the twenty-first century (pp. 118-139). Portsmouth, NH: Boynton/Cook.

Selwyn, N. (2009). Faceworking: exploring students' education-related use of Facebook. Learning, Media and Technology, 34(2), 157-174.

Selwyn, N. (2010). Looking beyond learning: Notes towards the critical study of educational technology. Journal of Computer Assisted Learning, 26(1), 65-73.

Selwyn, N. (2012). Making sense of young people, education and digital technology: The role of sociological theory. Oxford Review of Education, 38(1), 81-96. 
Selwyn, N. (2015). Technology and education-Why it's crucial to be critical. In S. Bulfin, N. Johnson \& C. Bigum (Eds.), Critical perspectives on technology and education (pp. 245255).

Serafini, F. (2012). Expanding the four resources model: Reading visual and multi-modal texts. Pedagogies: An International Journal, 7(2), 150-164.

Shabani, K., Khatib, M., \& Ebadi, S. (2010). Vygotsky's zone of proximal development: Instructional implications and teachers' professional development. English language teaching, 3(4), 237.

Shulman, L. S. (1986). Those who understand: Knowledge growth in teaching. Educational researcher, 15(2), 4-14.

Smyth, R. (2006). Exploring congruence between Habermasian philosophy, mixed-method research, and managing data using NVivo. International Journal of Qualitative Methods, $5(2), 131-145$

Song, A. Y. (2016). Operationalizing Critical Digital Literacies: A Holistic Approach to Literacy Education in the Modern Age. Talking Points, 28(1), 17.

Strauss, A., \& Corbin, J. M. (1997). Grounded theory in practice. Los Angeles, CA: Sage.

Stornaiuolo, A., \& LeBlanc, R. J. (2016). Scaling as a literacy activity: Mobility and educational inequality in an age of global connectivity. Research in the Teaching of English, 50, 263287.

Street, B. (1984). Literacy in theory and practice. Cambridge, MA: Cambridge University Press.

Street, B. (1998). New literacies in theory and practice: What are the implications for language in education? Linguistics and Education, 10(1), 1-24. 
Sutton, S. R. (2011). The preservice technology training experiences of novice teachers. Journal of Digital Learning in Teacher Education, 28(1), 39-47.

Terwel, J. (1999). Constructivism and its implications for curriculum theory and practice. Journal of curriculum studies, 31(2), 195-199.

The New London Group. (1996). A pedagogy of multiliteracies: Designing social futures. Harvard educational review, 66(1), 60-93.

Tondeur, J., Kershaw, L. H., Vanderlinde, R. R., \& Van Braak, J. (2013). Getting inside the black box of technology integration in education: Teachers' stimulated recall of classroom observations. Australasian Journal of Educational Technology, 29(3), 434449.

Tondeur, J., van Braak, J., Ertmer, P. A., \& Ottenbreit-Leftwich, A. (2017). Understanding the relationship between teachers' pedagogical beliefs and technology use in education: a systematic review of qualitative evidence. Educational Technology Research and Development, 65(3), 555-575.

Tondeur, J., van Braak, J., Sang, G., Voogt, J., Fisser, p. , \& Ottenbreit-Leftwich, A. (2012). Preparing pre-service teachers to integrate technology in education: A synthesis of qualitative evidence. Computers and Education, 59(1), 134-144.

Tondeur, J., van Keer, H., van Braak, J., and Valcke, M. (2008). ICT integration in the classroom: Challenging the potential of a school policy. Computers and Education, 51, 212-223.

Topper, A., \& Lancaster, S. (2013). Common challenges and experiences of school districts that are implementing one-to-one computing initiatives. Computers in the Schools, 30(4), 346-358. 
Tucker, B. (2012). The flipped classroom. Education Next, 12(1), 82-83.

Udesky, L. (2015). Classroom coaches critical as teachers shift to common core. Retrieved from http://edsource.org/2015/classroom-coaches-critical-as-teachers-shift-to-common-core

van Laar, E., van Deursen, A. J., van Dijk, J. A., \& de Haan, J. (2017). The relation between 21st-century skills and digital skills: A systematic literature review. Computers in human behavior, 72, 577-588.

Vygotsky, L. S. (1978). Mind in society: The development of higher psychological processes. Cambridge, MA: Harvard University Press.

Watulak, S.L. \& Kinzer, C.K. (2013). Beyond technology skills: Toward a framework for critical digital literacies in pre-service technology education. In J. Avila \& J.Z. Pandya (Eds.), Critical digital literacies as social praxis (pp. 127-153). New York, NY: Peter Lang.

Wells, G. (1999). Dialogic inquiry: Towards a socio-cultural practice and theory of education Cambridge: Harvard University Press.

Wenger, E., McDermott, R. A., \& Snyder, W. (2002). Cultivating communities of practice: A guide to managing knowledge. Boston, MA: Harvard Business Press.

Wetzel, K., Buss, R., Foulger, T. S., \& Lindsey, L. (2014). Infusing educational technology in teaching methods courses: Successes and dilemmas. Journal of Digital Learning in Teacher Education, 30(3), 89-103.

Weyers, M., Strydom, H., \& Huisamen, A. (2014). Triangulation in social work research: The theory and examples of its practical application. Social Work, 44(2), 207-222.

Won, S. G., Evans, M. A., Carey, C., \& Schnittka, C. G. (2015). Youth appropriation of social media for collaborative and facilitated design-based learning. Computers in Human Behavior, 50, 385-391. 
Yelland, N. (2006). Changing worlds and new curricula in the knowledge era. Educational Media International, v43, 121-131.

Young, J., Young, J., \& Shaker, Z. (2012). Technological Pedagogical Content Knowledge (TPACK) Literature Using Confidence Intervals. Techtrends: Linking Research \& Practice To Improve Learning, 56(5), 25-33.

Zeichner, K. (2012). The turn once again toward practice-based teacher education. Journal of Teacher Education, 63(5), 376-382. 


\section{APPENDIX A: GRADUATE STUDENTS SELF-INDICATED CONTENT AREAS}

(open-ended answers) 52 responses

Mathematics

ELA

Health

Industrial Technology

All

First grade

Math

chemistry (physical sciences?

social studies

Engineering

Business

English 
Elementary Teacher

Chemistry

Math, English Language Arts, Science, Social Studies

Science

Science

Social Studies

Gen Ed Kindergarten - all subjects

Elementary--math and science.

Reading and Language Arts

Communication

All

Physics - Secondary

English Language Arts

English/Montessori

Social Science, Communications, Digital Media, and English 
all

Grade 4 Gen Ed

Language Arts and Social Studies

ESL and ESL GED test preparation

Reading

I am certified in ELA and Science

ELA

5 th grade general education

English

Spanish

Science

Elementary - 2nd

ELA

TESOL

communication 
English Language Arts

Science

English, Library and Information Science, Education

Special Education Reading and Math

It was ELA

Literacy

Elementary

Math

Special Education

FCS 


\section{Information and Consent Form for Research Project}

\section{Introduction}

Research is being conducted by doctoral candidate Vicki A. Hosek at Middle State University to investigate how preservice teachers (PSTs) recruit their critical technological, pedagogical, and content area knowledge (C-TPACK) and critical digital literacy knowledge and understanding for their student teaching practices. We would like to invite you participate in this study. You must be over 18 years of age to participate.

Procedures

Study A: Participation in this study is voluntary. Not participating will not affect your current standing as a student teacher and will not impact any evaluations of you during your student teaching, and with Middle State University. Your responses are nonevaluative with respect to your lesson plans and student teaching. Refusal to participate involves no penalty or loss of benefits. You may discontinue participation at any time without penalty or loss of benefits. You can also skip questions you do not feel like answering.

If you choose to take part in this research study you will be asked to complete a TPACK survey. Included on the survey are likert-scale questions as well as open-ended questions which require a written response. The survey will be administered and collected during a regularly scheduled TCH 306/219 class or at the student teaching informational meetings 
before the end of the fall 2017 semester. Further participation may be requested dependent upon your TPACK survey and open-ended question answers. Subsequent participation includes allowing Ms. Hosek obtain a copy of lesson plans related to technology integration and critical digital literacy that you create for your student teaching in spring 2018. In addition, Ms. Hosek will observe your implementation of those lesson plans during your student teaching in spring 2018. Finally, a 45-60 minute interview will be conducted by arrangement, and at your convenience, at an agreed upon time/date/location following the observations. The interview will be audio recorded and transcribed verbatim. You will be provided with the analysis of your interview for your review to ensure that feel fairly represented. The data from this study which includes the surveys, lesson plan copies, and audio recordings will be destroyed after 5 years.

Study B: In addition, Ms. Hosek is intending to conduct future research concerning how the information learned from this study relates to the future teaching practices of the participants. Your help would be greatly appreciated. This would require you to sign your consent that you are willing to allow Ms. Hosek to follow-up with you once you are a practicing teacher. There is a signature line at the end of this document should you choose to consent to being contacted in the future.

\section{Risks/Discomforts}

You may be concerned about whether your participation or lack of participation could negatively impact your student teaching evaluations. Ms. Hosek is not the evaluating instructor for student teachers nor is she involved in student teaching in any way. 
Regardless, every effort to ensure confidentiality will be taken to eliminate this very minimal potential risk. Your participation in this study is voluntary and students who choose not to participate will not be included in research reports. In addition, participant identity will remain completely confidential. Only Ms. Hosek will identify the participant lesson plans to ensure that the course instructor has no knowledge of who has chosen to participate.

Benefits

There are no direct benefits of this research to the participants. An indirect benefit may be increased insight about how technology integration and critical digital literacy can be applied to your teaching practices.

\section{Confidentiality}

All information provided will remain confidential and will only be reported as group data with no identifying information.

For questions about this research, Vicki Hosek can be contacted via email at $\operatorname{xxxx} @ \operatorname{xxx.xxx}$. If you have any questions about your rights as a subject/participant in this research, or if you feel you have been placed at risk, you can contact the Research Ethics \& Compliance Office at Middle State University at $(\mathbf{x x x}) \mathbf{x x x}-\mathbf{x x x x}$ or via email at

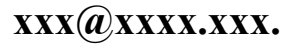

You will be given a copy of this consent form for your records. 
I consent to participate in the above study called Study A.

Signature

Date

I consent to be contacted in the future, as explained above in the section called Study B.

Signature

Date 


\section{APPENDIX C: PHASE 2 INFORMATION AND CONSENT EMAIL}

\section{Information and Consent Form for Research Project - PHASE 2}

Hello ! Recently, you completed a survey for the research project I am conducting for my dissertation, and you indicated a willingness to be contacted regarding an additional phase of this study. We would like to invite you to further participate in this study, which I am conducting under the supervision of Dr. Lara Handsfield. You must be over 18 years of age to participate. If you choose to participate, your name will be entered into a drawing where 2 participants' names will be drawn to receive a $\mathbf{\$ 5 0}$ Visa Gift Card each.

If you choose to take part in this next phase of the research study, I will ask you to provide copy of lesson plans in which you intend to integrate technology. I will also observe you teaching those lessons. Finally, after I observe, we would arrange a time and location that is convenient for you for an interview about your implementation of those lesson plans. The interview would take approximately $30-45$ minutes. Ideally, the interview will be conducted in person either at your school or at MSU. If necessary, it can be conducted online through SKYPE, GoogleHangout, FaceTime or other format you are familiar with. Interviews will be audiorecorded. My purpose is not to evaluate your teaching. Rather, I am interested in how your plans for technology integration translate to your teaching practices.

Participation in this study is voluntary. Not participating will not affect your current standing as a graduate student and will not impact any evaluations and/or assessments of you during your graduate course at Middle State University. Refusal to participate involves no penalty or loss of benefits. You may discontinue participation at any time without penalty or loss of benefits.

You may be concerned about whether your participation or lack of participation could negatively impact your student teaching evaluations. Please be assured that neither I, nor Dr. Handsfield, are the evaluating instructors for this course. We will do everything we can to protect your confidentiality. There are no direct benefits of this research to the participants. An indirect benefit may be increased insight about how technology integration and critical digital literacy can be applied to your teaching practices.

For questions about this research, I can be contacted via email at xxxxx@xxx.xxx. If you have any questions about your rights as a subject/participant in this research, or if you feel you have been placed at risk, you can contact the Research Ethics \& Compliance Office at Middle State University at (xxx) xxx-xxxx or via email at xxx@xxx.xxx. You will be given a copy of this letter for your records. 
Do you wish to participate in this next phase of the study? If so, please click on the following link to provide me with your consent and your school where you are teaching and class information.

\section{Link to: Consent to participate and school information}

Thank you for your time!!

Vicki A. Hosek

Doctoral Candidate

Illinois State University

\section{LINK ON EMAIL ABOVE INCLUDED THIS CONSENT FORM:}

\section{Hello! Please answer the questions that follow this information if you are willing to} participate in Phase 2 of my study. Thank you!

\section{Information and Consent Form for Research Project - Phase 2}

Hello! Recently, you completed a survey for the research project I am conducting for my dissertation, and you indicated a willingness to be contacted regarding an additional phase of this study. We would like to invite you to further participate in this study, which I am conducting under the supervision of Dr. Lara Handsfield. You must be over 18 years of age to participate. If you choose to participate, your name will be entered into a drawing where 2 participants' names will be drawn to receive a $\$ 50$ Visa Gift Card each.

If you choose to take part in this next phase of the research study, I will ask you to provide copy of lesson plans in which you intend to integrate technology. I will also observe you teaching those lessons. Finally, after I observe, we would arrange a time and location that is convenient for you for an interview about your implementation of those lesson plans. The interview would take approximately 30-45 minutes. Ideally, the interview will be conducted in person either at your school or at MSU. If necessary, it can be conducted online through SKYPE, GoogleHangout, FaceTime or other format you are familiar with. Interviews will be audiorecorded.

My purpose is not to evaluate your teaching. Rather, I am interested in how your plans for technology integration translate to your teaching practices. Participation in this study is voluntary. Not participating will not affect your current standing as a graduate student and will not impact any evaluations and/or assessments of you during your graduate course at Middle State University. Refusal to participate involves no penalty or loss of benefits. You may discontinue participation at any time without penalty or loss of benefits.

You may be concerned about whether your participation or lack of participation could negatively 
impact your student teaching evaluations. Please be assured that neither I, nor Dr. Handsfield, are the evaluating instructors for this course. We will do everything we can to protect your confidentiality. There are no direct benefits of this research to the participants. An indirect benefit may be increased insight about how technology integration and critical digital literacy can be applied to your teaching practices.

For questions about this research, I can be contacted via email at xxxxx@xxx.xxx. If you have any questions about your rights as a subject/participant in this research, or if you feel you have been placed at risk, you can contact the Research Ethics \& Compliance Office at Middle State University at $(\mathrm{xxx}) \mathrm{xxx}-\mathrm{xxxx}$ or via email at xxx@xxx.xxx.You will be given a copy of this letter for your records.

Sincerely,

Vicki Hosek 


\title{
APPENDIX D: SURVEY OF TEACHER KNOWLEDGE OF TEACHING AND
}

\author{
TECHNOLOGY
}

\section{Survey of Teacher Knowledge of Teaching and Technology}

\section{Start of Block: Block 4}

Q1 Hello! My name is Vicki Hosek, and I am a doctoral student at Illinois State University working under the supervision of Dr. Lara to investigate how practicing teachers utilize their knowledge about critical theory, technology, pedagogy, and content areas for their teaching practices. We would like to invite you to participate in this study. You must be over 18 years of age to participate.

\section{Procedures}

Participation in this study is voluntary. Not participating will not affect your current standing as a student and will not impact any evaluations and/or assessments. Refusal to participate involves no penalty or loss of benefits. You may discontinue participation at any time without penalty or loss of benefits. If you choose to take part in this research study you will be asked to complete an online survey. The survey will take approximately 20 minutes. You can also skip any questions you do not feel like answering. If you complete ALL SECTIONS of this survey, you will be entered into a drawing for a $\$ 50$ Visa Gift Card. Three names will be drawn to receive the gift cards. If your name is drawn, you will be notified by email.

\section{Risks/Discomforts}

You may be concerned about whether your participation or lack of participation could negatively impact your grade. Please be assured that neither I, nor Dr.Lara, are the evaluating instructors for your courses. Regardless, every effort to ensure confidentiality will be taken to eliminate this very minimal potential risk. Participant identity will remain completely confidential.

\section{Benefits}

There are no direct benefits of this research to the participants. An indirect benefit may be increased insight about how technology integration and critical digital literacy can be applied to your teaching practices.

For questions about this research, I can be contacted via email at xxx@xxx.xxx. If you have any questions about your rights as a subject/participant in this research, or if you feel you have been placed at risk, you can contact the Research Ethics \& Compliance Office at Middle State University at (xxx) xxx-xxxx or via email at xxx@xxx.xxx. Please print a copy of this letter for your records. 
Thank you for your time and your help!

Vicki Hosek

Q2 By completing this survey, you are consenting to participate in this phase of this study.

Q3 Name :

Q4 Email Address:

Q5 Later this spring semester, I will be conducting a second phase of this study. I would also like to ask for your further participation dependent upon your survey and open-ended question answers.

Q6 Please click "YES," if you are willing to be contacted in the future. If you do not click "YES" you will not be contacted.

YES (1)

\section{End of Block: Block 4}

\section{Start of Block: Default Question Block}

Q7 SURVEY: Teacher Knowledge of Teaching and Technology

Thank you for taking time to complete this survey. Please answer each question to the best of your knowledge. Your thoughtfulness and candid responses will be greatly appreciated. Your 
individual name or identification number will not at any time be associated with your responses. Your responses will be kept completely confidential and will not influence your course grade. If you do not want to answer a question, you may simply skip that question/response and move on to the next.

Below, you will find this survey contains TWO SECTIONS. The first contains questions about your knowledge of teaching and technology and the second contains demographics questions.

\section{End of Block: Default Question Block}

\section{Start of Block: Block 2}

\section{Q17}

\section{TEACHING AND TECHNOLOGY QUESTIONS}

Technology is a broad concept that can mean a lot of different things. For the purpose of this questionnaire, technology is referring to digital technology/technologies - that is, the digital tools we use such as computers, laptops, iPads, handhelds, interactive whiteboards, software programs, social media platforms, etc. Technologies are the TOOLS we use. Digital literacies are the PRACTICES that we do.

Throughout this questionnaire, you will see the term "critical literacy." Critical literacy is based on critical theory. You may have also heard this term referred to as "critical pedagogy." For the purposes of this survey, they represent the same thing. Please answer all of the questions. If you are uncertain of, or neutral about, your response for the likert scale questions, you may always select "Neither agree nor disagree."

Q18 Technology Knowledge (TK) - an understanding of technology tools to apply them productively in your work and everyday lives, and the ability to recognize when technology can assist or impede the achievement of a goal. Such knowledge allows a person to accomplish a variety of different tasks using the technology, as well as to develop different ways of accomplishing a given task. 
Strongly Disagree $=S D$ Disagree $=D$ Neither Agree/Disagree $=N$ Agree $=A$ Strongly Agree $=S A$ 


\begin{tabular}{|c|c|c|c|c|c|}
\hline & $\mathrm{SD}(1)$ & $\mathrm{D}(2)$ & $\mathrm{N}(3)$ & A (4) & SA (5) \\
\hline $\begin{array}{l}\text { I have heard } \\
\text { of this term } \\
\text { (Technology } \\
\text { Knowledge) } \\
\text { before and it } \\
\text { is a familiar } \\
\text { idea to me. } \\
\text { (1) }\end{array}$ & 0 & $\bigcirc$ & 0 & 0 & 0 \\
\hline $\begin{array}{l}\text { I know how } \\
\text { to solve my } \\
\text { own technical } \\
\text { problems. (2) }\end{array}$ & 0 & 0 & 0 & 0 & 0 \\
\hline $\begin{array}{l}\text { I can learn } \\
\text { technology } \\
\text { easily. (3) }\end{array}$ & 0 & 0 & $\bigcirc$ & 0 & 0 \\
\hline $\begin{array}{l}\text { I keep up } \\
\text { with } \\
\text { important } \\
\text { new } \\
\text { technologies. } \\
\quad(4)\end{array}$ & 0 & 0 & $\bigcirc$ & 0 & 0 \\
\hline $\begin{array}{l}\text { I frequently } \\
\text { play around } \\
\text { with } \\
\text { technology. } \\
\text { (5) }\end{array}$ & 0 & 0 & 0 & 0 & 0 \\
\hline $\begin{array}{l}\text { I know about } \\
\text { a lot of } \\
\text { different } \\
\text { technologies. } \\
\text { (6) }\end{array}$ & 0 & 0 & 0 & 0 & 0 \\
\hline $\begin{array}{l}\text { I have the } \\
\text { technical } \\
\text { skills I need } \\
\text { to use } \\
\text { technology. } \\
\text { (7) }\end{array}$ & 0 & 0 & 0 & 0 & 0 \\
\hline
\end{tabular}


I have had

sufficient

opportunities

to work with

different

technologies.

(8) 
Q19 Content Knowledge (CK) - a teacher's knowledge about the subject matter to be learned or taught. Strongly Disagree $=S D$ Disagree $=D$ Neither Agree/Disagree $=N$ Agree $=A$ Strongly Agree $=S A$ 


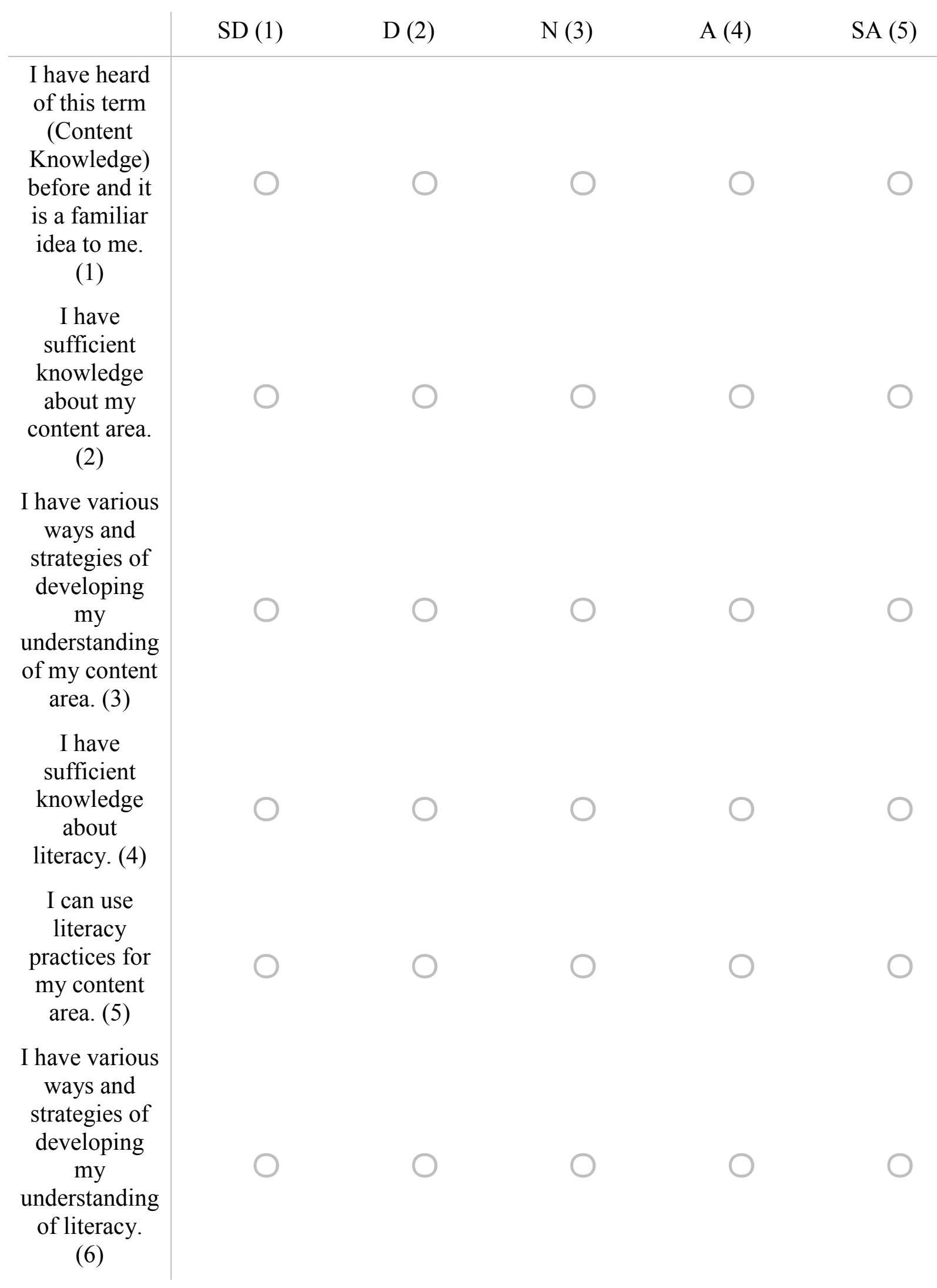


Q20 Pedagogical Knowledge (PK) - a teacher's deep knowledge about the processes and practices or methods of teaching and learning. This encompasses a teacher's beliefs about educational purposes, values, and aims. It also includes knowledge about techniques or methods 
used in the classroom and strategies for evaluating student understanding. Strongly Disagree $=S D$ Disagree $=D$ Neither Agree/Disagree $=N$ Agree $=A$ Strongly Agree $=S A$ 
SD (1)

D (2)

N (3)

A (4)

SA (5)

I have heard of this term (Pedagogical Knowledge) before and it is familiar to me. (1)

I know how to assess student performance in a classroom. (2)

I can adapt my teaching based upon what students currently understand or do not understand. (3)

I can adapt my teaching style to different learners. (4)

I can assess student learning in multiple ways. (5)

I can use a wide range of teaching approaches in a classroom setting. (6)

I am familiar with common student understandings and misconceptions. (7) 
I know how to

organize and

manage a

classroom. (8) 
Q21 Pedagogical Content Knowledge (PCK) - a teacher's knowledge that allows him/her to interpret subject matter, find multiple ways to represent it, and adapt and tailor the instructional materials in ways that can access students' prior knowledge. Strongly Disagree $=S D$

Disagree $=D$ Neither Agree $/$ Disagree $=N$ Agree $=A$ Strongly Agree $=S A$
$\mathrm{SD}(1)$
$\mathrm{D}(2)$
$\mathrm{N}(3)$
A (4)
SA (5)

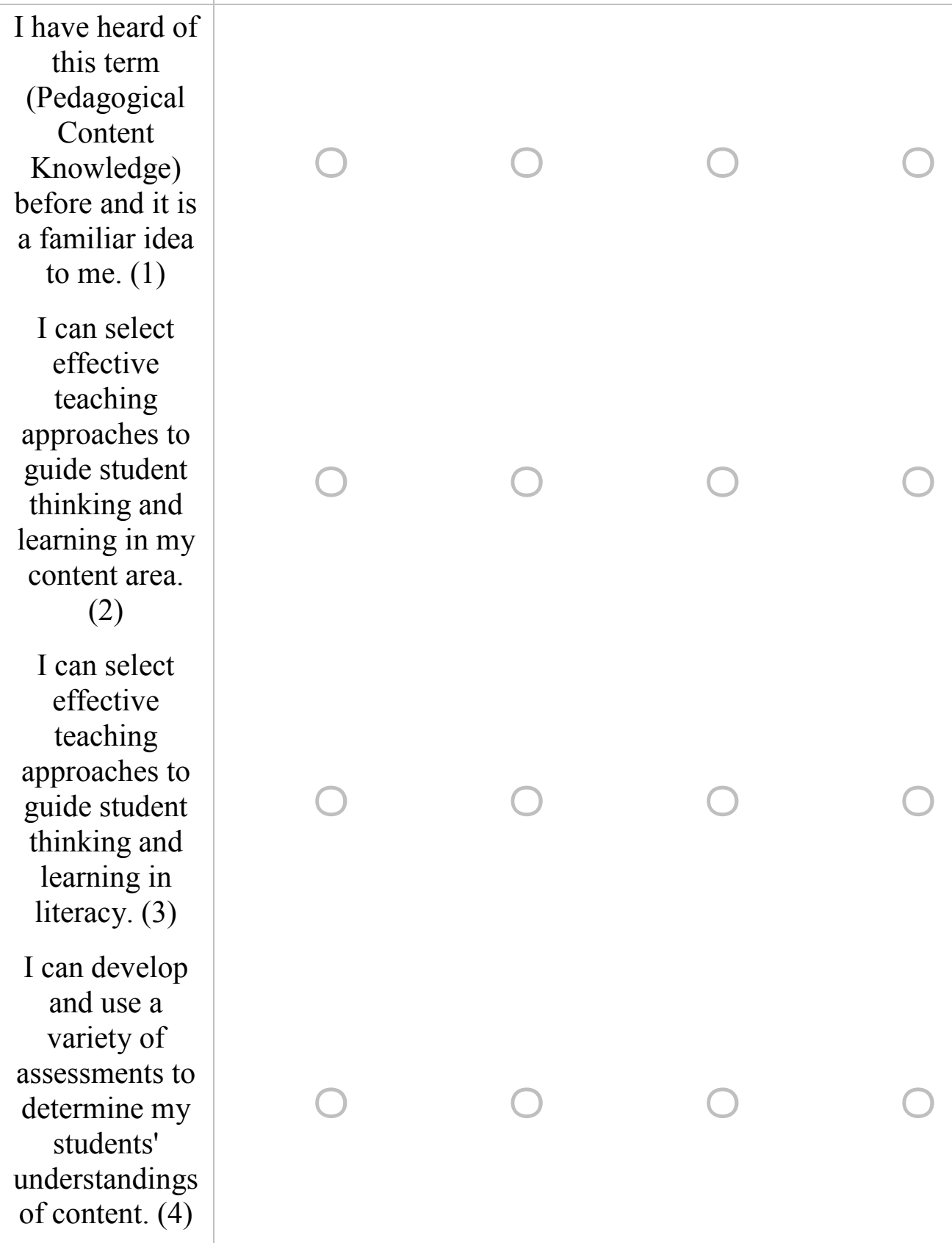


Q22 Technological Content Knowledge (TCK) - an understanding of the impact of technology on teaching practices and knowledge within a content area. This includes an understanding of the manner in which technology and content influence and constrain each other. It is an understanding of the manner in which the subject matter can be changed by the application of particular technologies. $\quad$ Strongly Disagree $=S D$ Disagree $=D$ Neither Agree/Disagree $=N$ Agree $=$ A Strongly Agree $=S A$
$\mathrm{SD}(1)$
$\mathrm{D}(2)$
$\mathrm{N}(3)$
A (4)
SA (5)

I have heard of this term

(Technological Content Knowledge) before and it is a familiar idea to me. (1)

I know about technologies that I can use for my understanding of my content area. (2)

I know about technologies that I can use for understanding and doing literacy. (3)

I feel comfortable using different technologies that would be helpful in advancing my students' understanding of the content. 
Q23 Technological Pedagogical Knowledge (TPK)- an understanding of how teaching and learning can change when particular technologies are used in particular ways. This includes knowing the pedagogical affordances and constraints of a range of technological tools as they relate to disciplinary and developmentally appropriate pedagogical designs and 
strategies. $\quad$ Strongly Disagree $=S D$ Disagree $=D$ Neither Agree/Disagree $=N$ Agree $=A$ Strongly Agree $=S A$ 


$\begin{array}{lllll}\text { SD (1) } & \mathrm{D}(2) & \mathrm{N}(3) & \mathrm{A}(4) & \mathrm{SA}(5)\end{array}$

I have heard of
this term
(Technological
Pedagogical
Knowledge)
before and it is
a familiar idea
to me. (1)
I can choose
technologies
that enhance
the teaching
approaches for
a lesson. (2)
I can choose
technologies
that enhance
students'
learning for a
lesson. (3)
My teacher
education
program
caused me to
think more
deeply about
how
technology
could
influence the
teaching
approaches I
use in my
classroom. (4)
I am thinking
critically about
how to use
technology in
my classroom.
(5)

(5) 
I can adapt the use of technologies that I am learning about to different teaching activities. (6)

Q24 Technology Pedagogical Content Knowledge (TPACK) - an understanding that emerges from interactions among content, pedagogy, and technology knowledge. It is the basis of effective teaching with technology, requiring an understanding of the representation of concepts using technologies; pedagogical techniques that use technologies in constructive ways to teach content; knowledge of what makes concepts difficult or easy to learn and how technology can help redress some of the problems that students face; knowledge of students' prior knowledge and theories of epistemology; and knowledge of how technologies can be used to build on existing knowledge to develop new epistemologies or strengthen old ones.

Strongly Disagree $=S D$

Disagree $=D$

Neither Agree/Disagree $=N$ 
Agree $=A$

Strongly Agree $=S A$ 
I have heard of
this term
(Technological
Pedagogical
Content
Knowledge)
before and it is
a familiar idea
to me. (1)
I can teach
lessons that
appropriately
combine
literacy,
technologies,
and teaching
approaches.

(2)

I can select technologies to use in my classroom that enhance what I teach, how I teach, and what students learn. (3)

I can use strategies that combine content, technologies, and teaching approaches that I learned about in my coursework in my classroom.

(4)

$\begin{array}{lllll}\mathrm{SD}(1) & \mathrm{D}(2) & \mathrm{N}(3) & \mathrm{A}(4) & \mathrm{SA}(5)\end{array}$
SD (1)
D (2)
$\mathrm{N}(3)$
A(4)
SA (5)

f

is


I can provide leadership in helping others to coordinate the use of content, technologies, and teaching approaches at my school and/or district.

I can choose technologies that enhance the content for a lesson. (6)

\section{Q25 Critical Technological Pedagogical Content Knowledge (CTPACK)}

\section{Digital Literacies \& Critical Digital Literacies}

Digital literacies have been defined as the participatory and collaborative practices and the engagement in meaning-making through the use of texts that are created, distributed, and exchanged through digital technologies (Lankshear \& Knobel, 2008). Critical Digital Literacies $(C D L)$ have been defined as the development and utilization of a perspective about digital technologies that critically reflects upon the social, cultural, and historical contexts of digital resources and environments as they are used and participated in (Watulak \& Kinzer, 2013). This includes the decoding, encoding, interrogation, and meaning-making with texts found in digital environments (Avila \& Pandya, 2013). As a result, students engage in opportunities to critically reflect on their cultural worlds, develop understandings of other cultures, and develop and represent their own cultures and identities using digital tools (Avila \& Pandya, 2013).

Strongly Disagree $=S D$

Disagree $=D$

Neither Agree/Disagree $=N$ 
Agree $=A$

Strongly Agree $=S A$ 


\begin{tabular}{c|ccc} 
& SD (1) D (2) N (3) & A (4) \\
\hline I learned about \\
digital literacies \\
in my teacher \\
education \\
program. (1)
\end{tabular}




\section{I understand \\ how to \\ integrate \\ technology and \\ critical digital \\ literacy into my \\ lesson planning and instruction.}

(7)

I can utilize

critical digital

literacies to

become

familiar with

common

student

understanding

and

misconceptions.

(8)

I am confident about

employing

critical theory

in combination with

technologies to help me

understand and

do literacy. (9)

I utilized

critical digital

literacies in my

lesson planning during my

teacher

education

program. (10)

I utilized

critical digital

literacies while teaching during my clinicals.

(11) 


\section{I continually \\ plan to incorporate critical digital \\ literacies practices into \\ my lesson \\ planning and instruction. (12)}

Q26 The following section contains questions that will ask you about technologies (tools), and critical digital literacies. Please complete this section by typing your responses.

Q27 Describe a specific episode where a professor or an instructor effectively demonstrated or modeled combining content, technologies, and teaching approaches in a classroom lesson. Please include in your description what content was being taught, what technology was used, and what teaching approach(es) was implemented.

Q29 Describe a specific episode where you effectively demonstrated or modeled combining content, technologies, and teaching approaches in a classroom lesson. Please include in your description what content you taught, what technology you used, and what teaching approach(es) you implemented. If not applicable, please indicate. 
Q30 Do you integrate technology into your teaching practices? If so, how do you?

Q31 If applicable, describe a time during your teacher education program when you learned about critical digital literacies.

Q32 If applicable, describe a time when you have personally incorporated critical digital literacies into your teaching practices. 
Q33 Do you incorporate critical digital literacies into your lessons? If so, how do you?

Q34 What do you believe is the most important thing to consider when integrating technology? Why?

\section{End of Block: Block 2}

\section{Start of Block: Demographics Questions}

Q8 DEMOGRAPHIC SURVEY QUESTIONS: For the following items, click on the response that best describes you, or fill in the blank where necessary. 
Q38 Are you currently a practicing middle or secondary level teacher?

\section{Yes (1)}

No (2)

Q15 What is your Content Area(s)?

Q16 Which level of students do you currently teach?

Middle School (1)

High School (2)

Q39 If you are a practicing teacher, which school district do you teach in?

Q36 Have you taken any educational technology courses, including any taken during and/or outside of your degreed program(s)?

Yes (1)

No (2)

Q37 Please list the educational technology course(s) you have taken if applicable. 
Q9 With which gender identity do you most identify?

\section{Female (1)}

Male (2)

Transgender Female (3)

Transgender Male (4)

Gender Variant/Non-conforming (5)

Not listed (6)

Prefer not to answer (7)

Q10 What is your age? 
Q11 Which race/ethnicity best describes you? (Please choose only one or use the blank to specify)

American Indian or Alaskan Native (1)

Asian / Pacific Islander (2)

Black or African American (3)

Hispanic American (4)

White / Caucasian (5)

Multiple ethnicity (Please describe) (6)

Other (Please describe) (7)

Q12 What was the primary language spoken in your childhood home?

Q13 What is the highest level of education you have completed?

High School (1)

Associates degree (2)

Bachelor's degree (3)

Master's degree (4)

Doctorate degree (5) 
Q14 What is your approximate family household income?
$\$ 0-\$ 24,000$
$\$ 25,000-\$ 49,000(2)$
$\$ 50,000-\$ 74,999$
$\$ 75,000$ - \$99,999 (4)
$\$ 100,000-\$ 124,999$
$\$ 125,000-\$ 149,000$
$\$ 150,000-\$ 174,999$
$\$ 175,000-\$ 199,999(8)$
$\$ 200,000$ and up (9)

End of Block: Demographics Questions 
Project: An Examination of How Preservice Teachers Recruit TPACK and Critical Digital Literacy for Classroom Practices

Interview procedure: You are being asked to participate in a research study investigating how PSTs recruit their critical technological, pedagogical, content area knowledge (CTPACK) and critical digital literacy knowledge and understanding for their student teaching practices. During this interview, I will ask you to respond to several questions. You may choose not to answer any or all of the questions. I will be recording the interview so that I can ensure that I have all of the information you provide. I may ask you at a later date to review my transcription of your interview and/or to clarify your answers to the questions to ensure that I have fairly represented your perspective. Your results will be confidential, and you will not be identified individually by name.

Your results will be confidential, and you will not be identified individually by name. Your responses are non-evaluative with respect to your lesson plans and teaching.

Informed consent: Please sign the informed consent form signaling your willingness to participate. 


\section{Guiding Questions:}

** I will begin by refreshing the PST's memory with his/her definitions of technology integration, digital literacy, and CDL that they provided in their surveys and initial interviews.

1. How do you feel technology integration fits with your content area? Why?

2. In what ways did your mentor teacher model technology integration?

3. How did his/her technology integration practices impact yours?

4. How do you feel your lesson plans concerning integrating technology recruited to the classroom?Why?

5. What successes do you feel you had with those lesson plans?

6. What do you think your students learned or "took away" from the use of technology in your lessons?

7. How could you tell what they learned?

8. Would you have changed anything? What?

9. In what ways did you have to adapt your lesson plans?

10. Why?

11. What challenges did you face incorporating technology integration while teaching? How did you address those challenges?

12. What ways could you have integrated more technology?

13. How did you incorporate CDL into your lessons that included technology integration?

14. Could you have incorporated more? How?

15. In what ways did your mentor teacher incorporate CDL with technology integration practices? 
16. How did his/her CDL practices impact yours?

17. How do you feel your lesson plans concerning CDL recruited to the classroom? Why?

18. What do you think your students learned or "took away" from the use of CDL in your lessons? How could you tell what they learned?

19. What successes do you feel resulted from the incorporation of CDL?

20. What challenges did you face incorporating technology integration while teaching?

21. What supports/has supported your technology integration practices?

22. What has supported/challenged your CDL practices in your teaching?

23. How did you address those challenges?

24. Looking back, in what other ways could you have incorporated CDL?

Closing: Thank you for participating in this interview. I greatly appreciate your time. Again, please be assured of the confidentiality of your answers. If you have any questions, please do not hesitate to contact me at: xxxx@xxx.xxx or by phone at (xxx)xxx-xxxx. 


\section{APPENDIX F: DIANE'S LESSON PLAN}

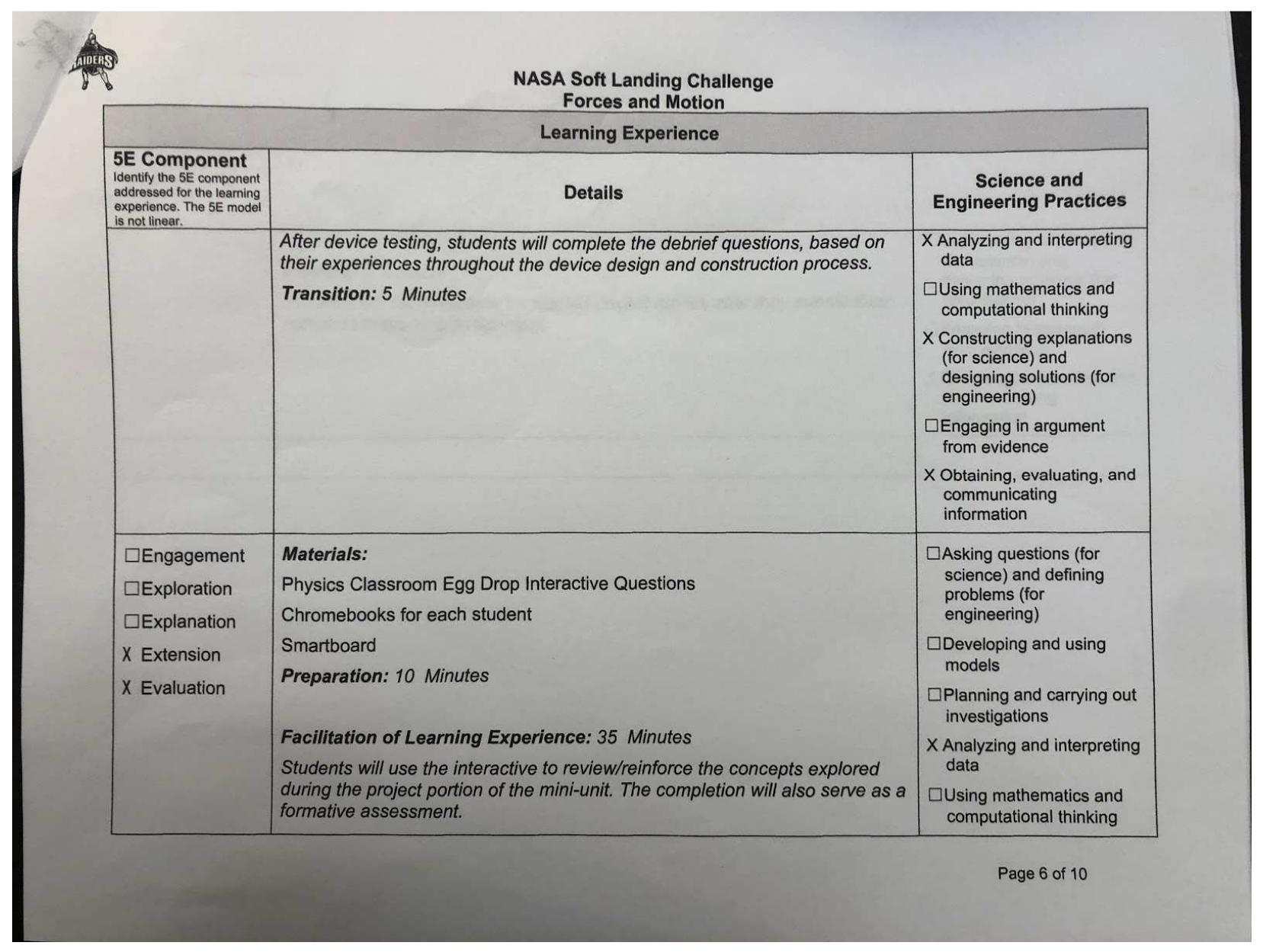




\section{APPENDIX G: KATE'S LESSON PLAN}

\section{Language Arts Lesson Plan for Monday, May 14th, 2018}

\begin{tabular}{|c|c|}
\hline Class Description & $\begin{array}{l}\text { At the middle level in this district, literacy instruction is conducted during two } \\
\text { separate courses (Literature/Composition and Language Arts). This section, } \\
\text { Language Arts, is devoted to instruction directly linked to writing and state } \\
\text { standards associated with writing. The section that I teach is at the 8th grade } \\
\text { level and is co-taught. }\end{array}$ \\
\hline Brief Overview & $\begin{array}{l}\text { The unit that we are currently in is an end-of-the-year trial project that my } \\
\text { team teachers and I are experimenting with this year. We are calling it the } \\
\text { "Passion Project," and it is a Genius-Hour-like independent study designed } \\
\text { using the 4-D's model. Students have chosen topics of interest and will be } \\
\text { presenting on these topics to the class at the end of next week. Sample } \\
\text { projects include: } \\
\text { How-to's } \\
\text { Musical Performances } \\
\text { - Research Proposals } \\
\text { Timelapse Videos }\end{array}$ \\
\hline Anticipatory Set & $\begin{array}{l}\text { The students have been working on this project for a week as of now, and } \\
\text { many of them will now be transitioning into their design and development } \\
\text { phase. The level of technology integration varies depending on the nature of } \\
\text { the project that the students chose to pursue. }\end{array}$ \\
\hline Prior Knowledge & $\begin{array}{l}\text { The students conducted a group project designed around the same model } \\
\text { prior to this unit, so they should be familiar with the process and the } \\
\text { formative/summative assessments. Ideas, data, research, and assessments } \\
\text { are all documented using Google Docs, a tool in which every student in the } \\
\text { class is fairly fluent. }\end{array}$ \\
\hline Tech Tools & $\begin{array}{l}\text { In addition to the navigation of the Google Doc, some students are choosing } \\
\text { to present their project findings through digital tools. My co-teacher and I } \\
\text { provided then a list of tools on a Google Doc at the start of the unit with very } \\
\text { little context. We eliminated the utilization of Google Slides as a viable } \\
\text { presentation option because of the students' familiarity with G Suite. Since } \\
\text { then, we have guided them into some fitting options given their project needs } \\
\text { and design. }\end{array}$ \\
\hline During the Lesson & $\begin{array}{l}\text { Today's lesson is more of an independent work day, as students are all at } \\
\text { different stages of the design and production process. My co-teacher and I } \\
\text { are hoping to hold formal and informal conferences with students today to ask } \\
\text { them about their means of presentation. In many cases, we'd like the students } \\
\text { to reflect on the appropriateness of the tools they are pursuing, evaluating the } \\
\text { benefits and drawbacks of such methods. }\end{array}$ \\
\hline Concluding the Lesson & $\begin{array}{l}\text { The conclusion of the lesson will consist of a brief progress check-in as a } \\
\text { class, if time allows. }\end{array}$ \\
\hline
\end{tabular}




\begin{tabular}{|c|c|c|c|}
\hline & $\begin{array}{l}\text { 4. What are the ethical } \\
\text { consequences of cloning and } \\
\text { stem-cell research? }\end{array}$ & & $\begin{array}{l}\text { Various other formative and } \\
\text { summative assessments }\end{array}$ \\
\hline \multirow[t]{2}{*}{ Quarter 4} & Theme 6: Beauty and Esthetics & Countries: Vary & \\
\hline & $\begin{array}{l}\text { Essential questions: } \\
\text { 1. How are perceptions of beauty and } \\
\text { creativity established? } \\
\text { 2. How do ideals of beauty and } \\
\text { aesthetic influence daily life? } \\
\text { 3. How do the arts both challenge } \\
\text { and reflect cultural perspectives? }\end{array}$ & $\begin{array}{l}\text { Recommended content: } \\
\text { Defining Beauty, Defining } \\
\text { Creativity, Visual and Performing } \\
\text { Arts. } \\
\text { Words to introduce quotes } \\
\text { Words that change meaning } \\
\text { according to their gender } \\
\text { Progressive tenses }\end{array}$ & $\begin{array}{l}\text { - Persuasive essay: concept of } \\
\text { beauty } \\
\text { - Email assignment } \\
\text { - Listen to song: maquillaje } \\
\text { - } \text { mas Bella } \\
\text { - Read la nina rubia } \\
\text { - Various readings on textile } \\
\text { arts } \\
\text { - Audio: thirty years of } \\
\text { Guernica } \\
\text { - Analysis of Bolero's work } \\
\text { - World Heritage site } \\
\text { presentation } \\
\text { - Various other formative and } \\
\text { summative assessments }\end{array}$ \\
\hline
\end{tabular}




\section{APPENDIX H: SARA'S LESSON PLAN}

Lesson plans for the week of April 16-20

Essential questions:

1. How are perceptions of beauty and creativity established?

2. How do ideals of beauty and aesthetic influence daily life?

3. How do the arts both challenge and reflect cultural perspectives

Unit summative assessment: persuasive essay on the concept of beauty

Grammar: words that change meaning according to gender

\section{Monday 16}

1. Introduce words that change meaning according to gender

2. Practice worksheet with words that change meaning according to gender

3. Palabra de la semana- la belleza

4. Introduce beauty vocabulary words

5. Do practice beauty worksheet/go over answers

6. Homework: General questions about beauty

\section{Tuesday 17}

1. Review beauty vocabulary words

2. Play Kahoot with vocab words

3. Go over general questions about beauty with partners-speaking activity with ppt

4. Do paso uno, dos, tres questions with Barbie picture, Dove video, make-up song , and what is beauty video-students will fill out corresponding worksheet on the nature of beauty

\section{Wednesday 18}

1. Review beauty vocabulary words

2. Review theme from La fea mas bella

3. Watch Aurora episode

\section{Thursday 19}

1. Finish Aurora episode

2. Watch transformation episode

3. Partner discussion- Do you think that it is true that Lety was hiding herself from her true beauty? Why did her physical appearance have to change?

4. Practice work on words that change meaning according to gender 